\title{
UNESCO/Republic of
} Korea Funds-in-Trust

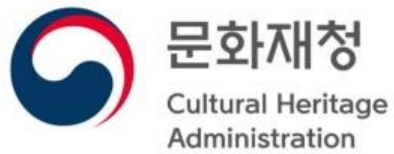

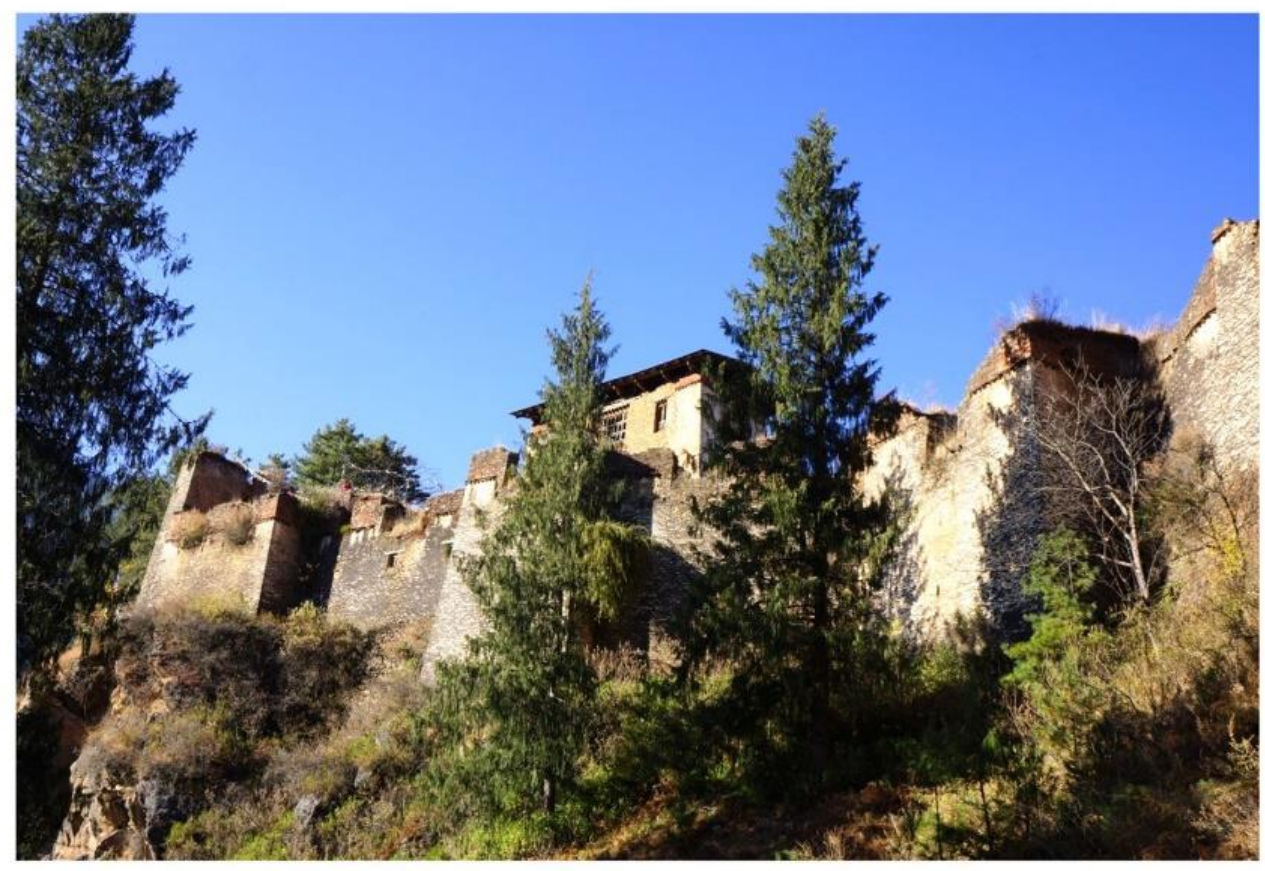

Final Technical Report on the results of the UNESCO/Korean Funds-in-Trust Project: Support for the Preparation for the World Heritage Serial Nomination of the Silk Roads in South Asia, 2013-2016 



\section{AICLI.}

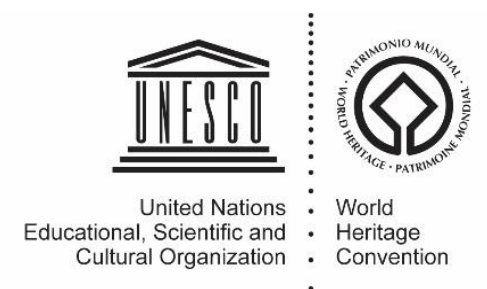

\section{UNESCO/Republic of Korea Funds-in-Trust}

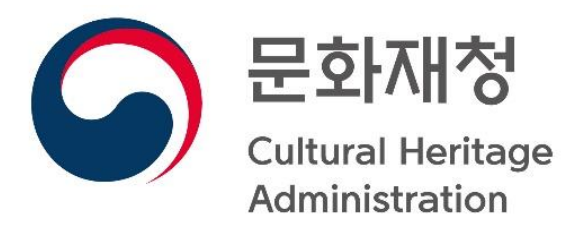

Final Technical Report on the results of the UNESCO/Korean Funds-in-Trust Project: Support for the Preparation for the World Heritage Serial Nomination of the Silk Roads in South Asia, 20132016 
Final Technical Report on the results of the UNESCO/Korean Funds-in-Trust project: Support for the Preparation for the World Heritage Serial Nomination of the Silk Roads in South Asia, 2013-2016

Executing Agency:

- UNESCO World Heritage Centre, in collaboration with UNESCO Field Offices in Kathmandu and New Delhi

Implementing partners:

- $\quad$ National Commissions for UNESCO of Bhutan, China, India, and Nepal

- $\quad$ Department of Archaeology of Nepal (DoA)

- $\quad$ Archaeological Survey of India (ASI)

- $\quad$ Division for Conservation of Heritage Sites, Department of Culture, Ministry of Home and Cultural Affairs, Royal Government of Bhutan

- $\quad$ State Administration of Cultural Heritage of China

- ICOMOS International

- $\quad$ ICOMOS International Conservation Centre - Xi’an (IICC-X)

- $\quad$ University College London, UK

Written \& compiled by: Tim Williams (Institute of Archaeology, University College London)

Edited by: Tim Williams, Roland Lin Chih-Hung (Asia and the Pacific Unit, World Heritage Centre, UNESCO) and Gai Jorayev (Institute of Archaeology, University College London)

Prepared for publication by Gai Jorayev at the Institute of Archaeology, University College London www.ucl.ac.uk/archaeology

ISBN: 978-0-9956132-0-1

Creative commons licence: Attribution-NonCommercial-NoDerivatives 4.o International. cC) $\left(\begin{array}{l}\text { Creative commons licence: Attribution-NonCommercial-NoDerivatives 4.0 International. } \\ \text { SY NC ND }\end{array}\right.$ Share, copy and redistribute this publication in any medium or format under the following
terms: Attribution - You must give appropriate credit and indicate if changes were made. NonCommercial - You may not use the material for commercial purposes. NoDerivatives - If you remix, transform, or build upon the material, you may not distribute the modified material.
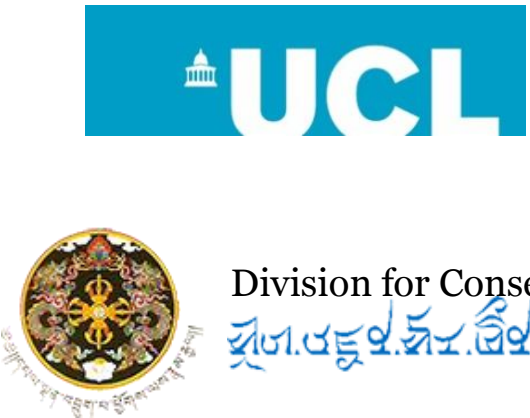

Division for Conservation of Heritage Sites

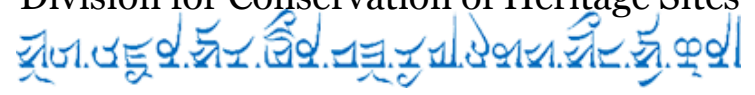

Ministry of Culture, Tourism and Civil Aviation

Department of Archaeology

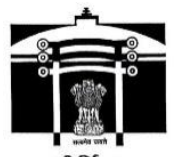

प्रत्नकीर्तिमपावृणु

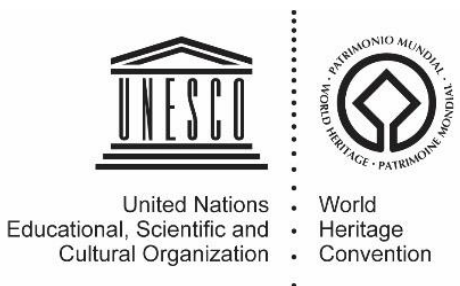




\section{Contents}

Foreword by Dr Roland Lin Chih-Hung $\ldots . \ldots \ldots \ldots \ldots \ldots \ldots \ldots \ldots \ldots \ldots \ldots \ldots \ldots \ldots \ldots \ldots \ldots \ldots \ldots \ldots \ldots \ldots$ 1

1 The Silk Roads in South Asia .............................................................4

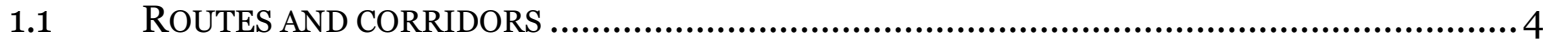

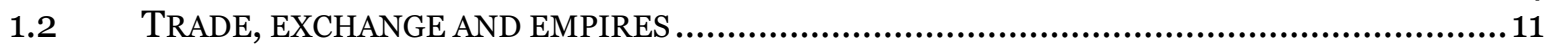

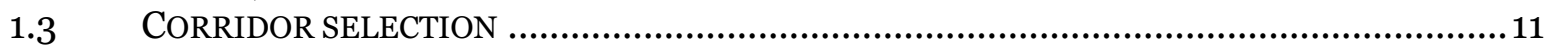

2 Background: UNESCO Silk Roads serial trans-national nomination

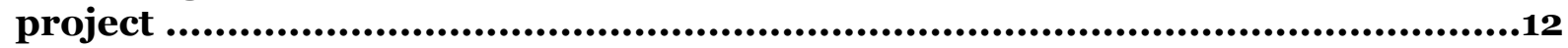

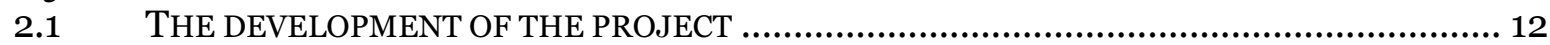

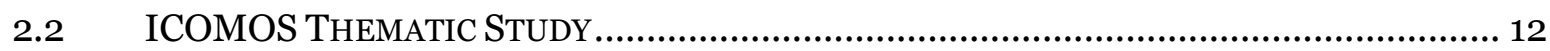

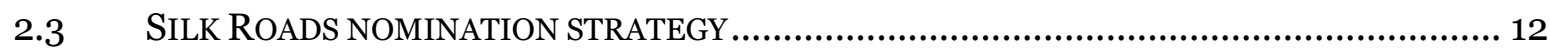

3 The UNESCO/Korean Funds-in-Trust "Support for the Preparation for the World Heritage Serial Nomination of the Silk Roads in South Asia Project" .... 14

3.1 WORKSHOP ON “NEPAL AND THE SILK ROADS”, KATHMANDU, SEPTEMBER 2011 ........ 14

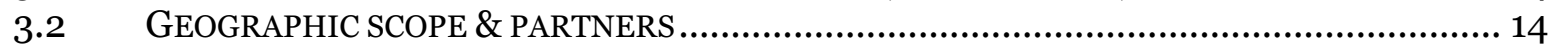

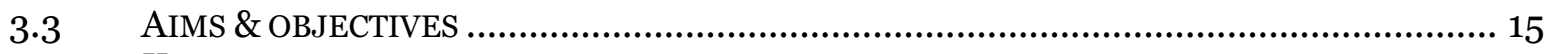

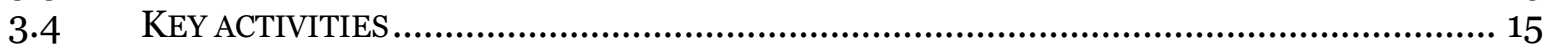

4 South Asian missions, workshops \& activities within the framework of the project .................................................................................................... 16

4.1 ADVISORY MISSION TO KATHMANDU, NEPAL: 28 APRIL - 2 MAY, 2013 …................. 16

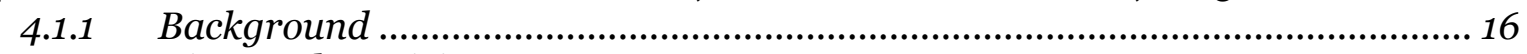

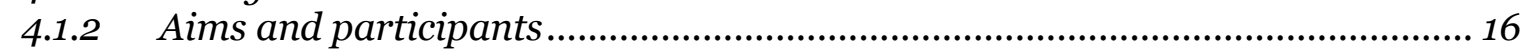

4.1.3 Outcomes .........................................................................................................

4.2 CONSULTATION MEETINGS IN NEPAL: 27 OCTOBER - 3 NOVEMBER 2013 ....................20

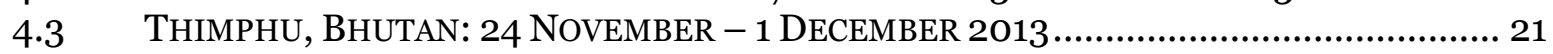

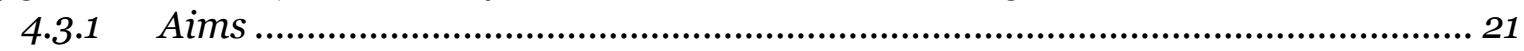

4.3.2 Workshop on Serial Nomination of Silk Roads in South Asia ............................. 21

4.3.3 Field visits ............................................................................................... 23

4.3.4 Meeting with Minister for Home \& Cultural Affairs, Bhutan .............................. 31

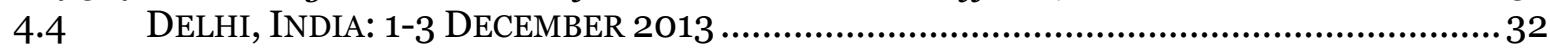

4.5 THIMPHU, BHUTAN: 20-22 AUGUST 2014 …...................................................... 36

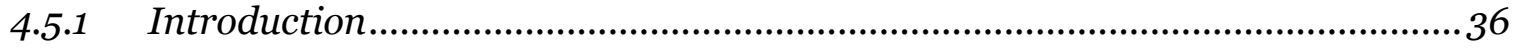

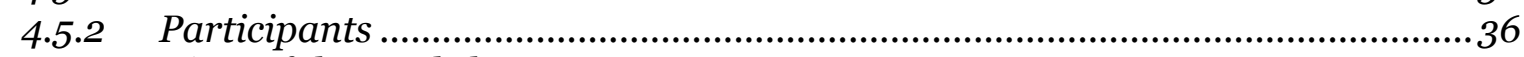

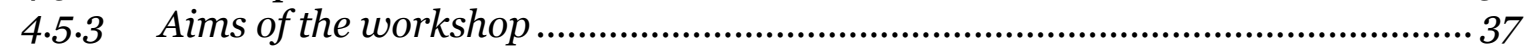

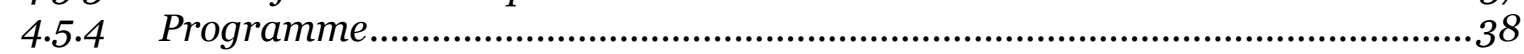

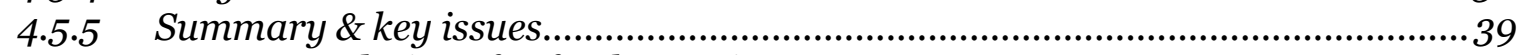

4.5.6 Recommendations for further action................................................................... 43

4.6 NEPAL: FACILITATION AND TECHNICAL SUPPORT FOR NEPALI NATIONAL SILK ROADS

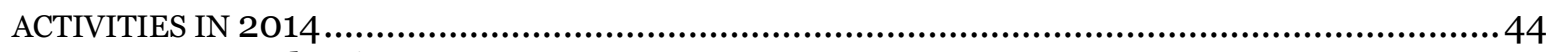

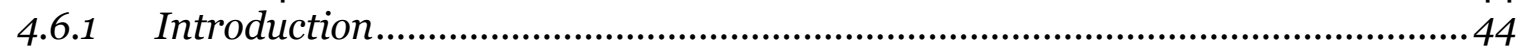

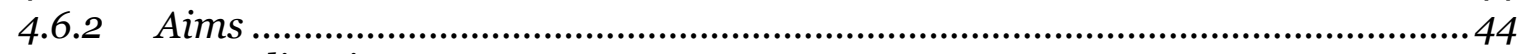

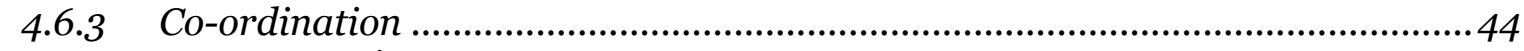

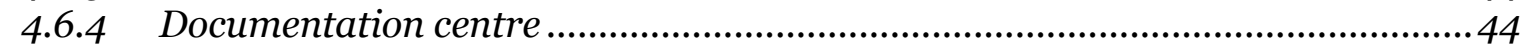

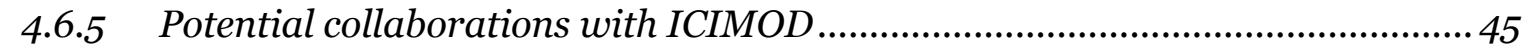

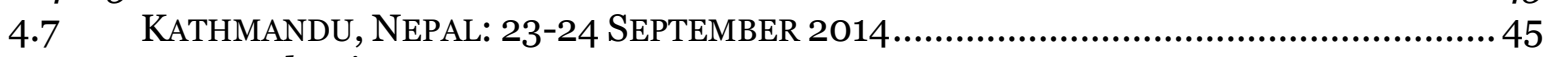

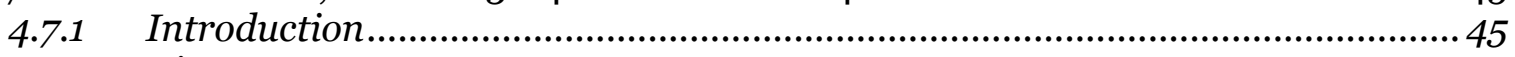

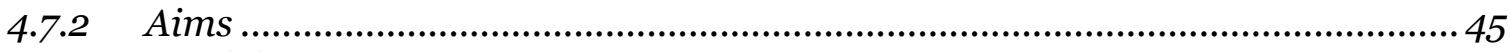

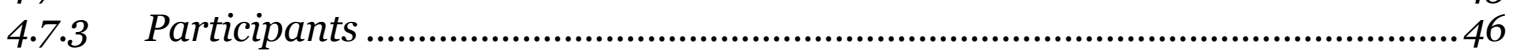

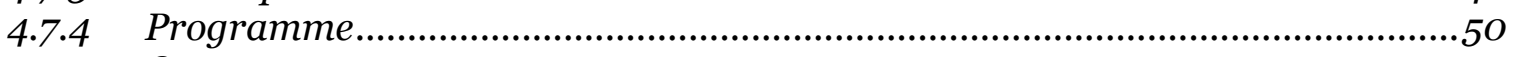

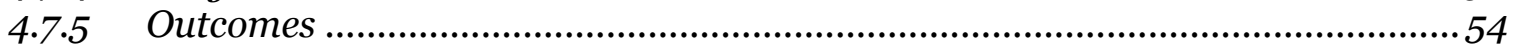

4.8 ALMATY, KAZAKHSTAN: 23-27 NOVEMBER 2015, 4TH MEETING OF THE COORDINATING

COMMITTEE OF THE SERIAL WORLD HERITAGE NOMINATION OF THE SILK ROADS...................58

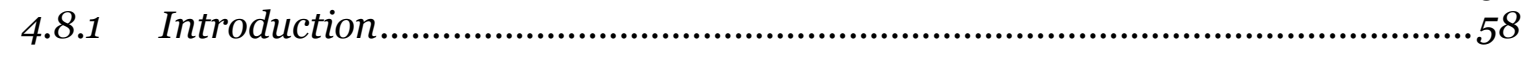




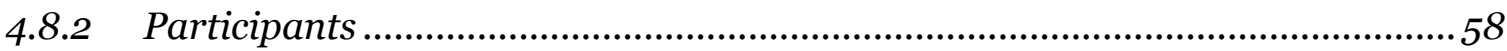

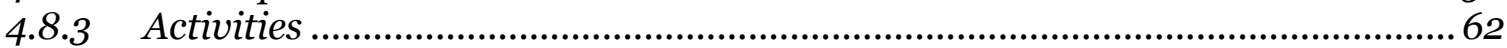

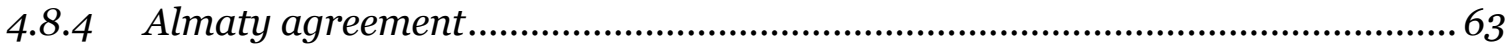

5 Nepal: Field expedition to Lumbini-Mustang corridor (January 2015)....... 64

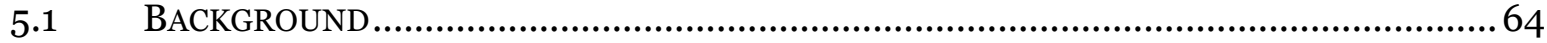

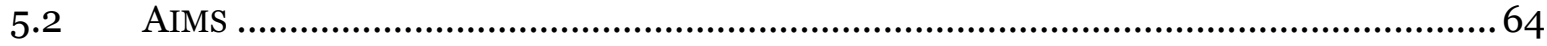

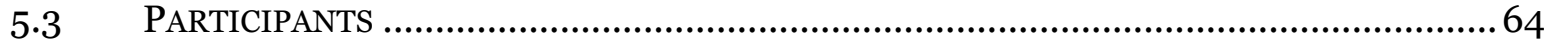

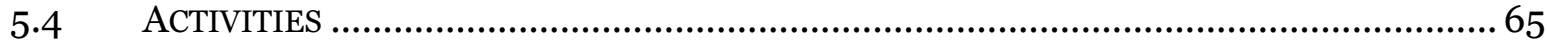

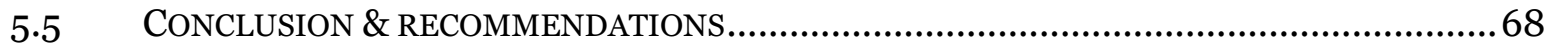

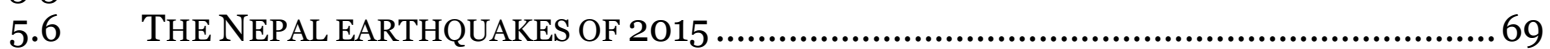

6 Complimentary Activities: Bhutan National Inventory ............................. 70

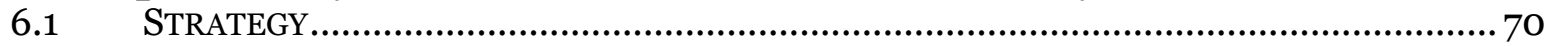

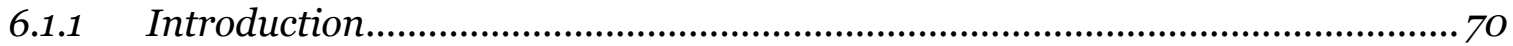

6.1.2 Objectives for the Bhutan National Inventory ....................................................71

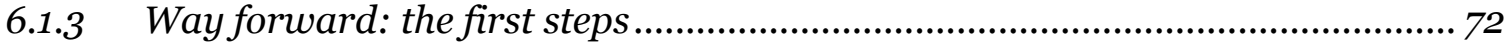

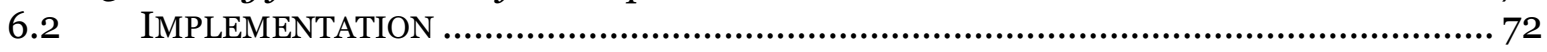

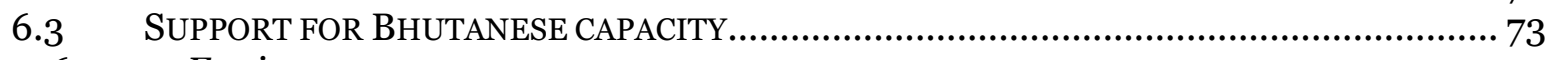

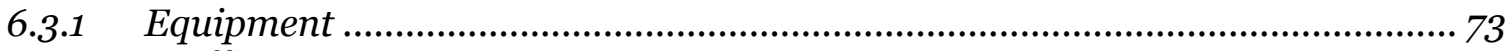

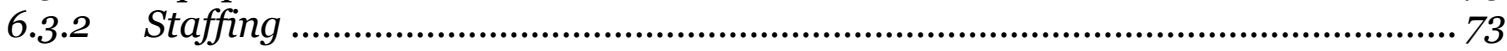

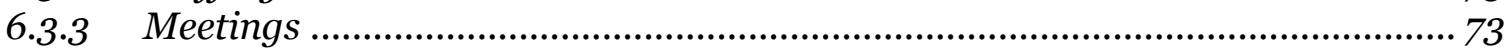

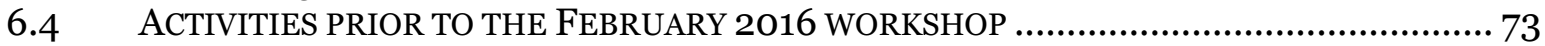

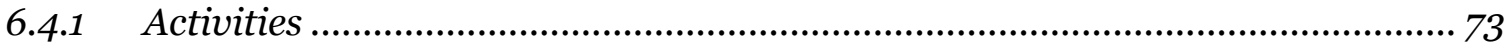

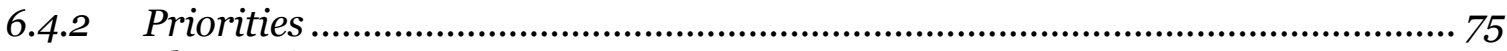

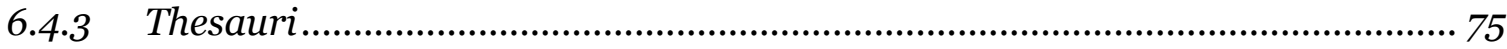

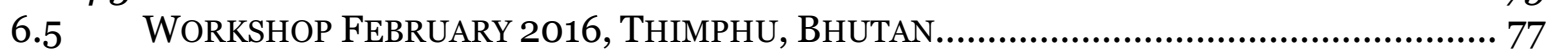

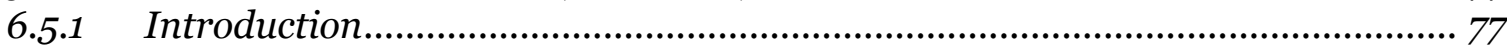

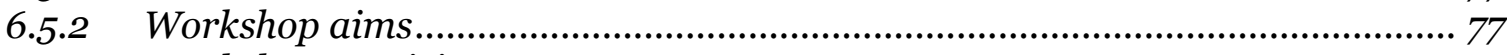

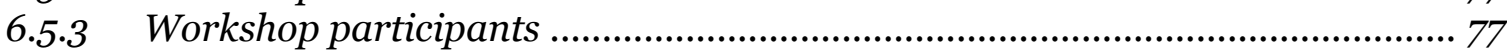

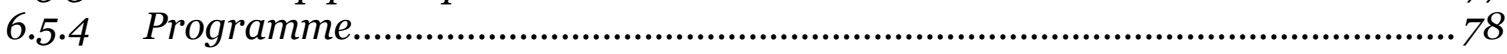

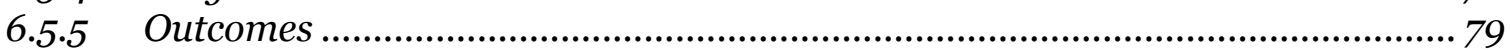

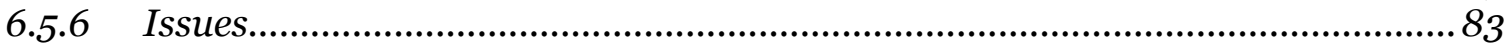

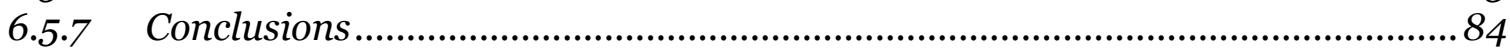

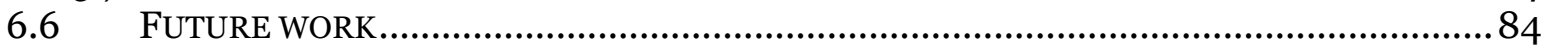

7 Complimentary Activities: Nepal National Inventory .......................... 85

8 Conclusion .......................................................................................8 86

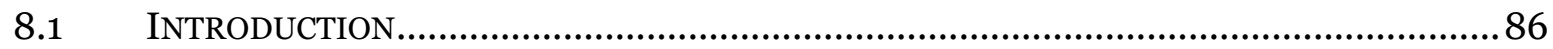

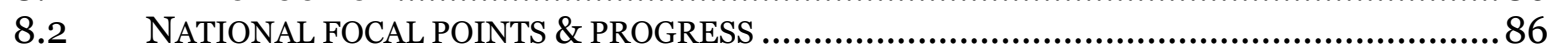

8.3 EXPANDING THE STATE PARTIES ENGAGED IN THE SOUTH ASIAN PROJECT ..................87

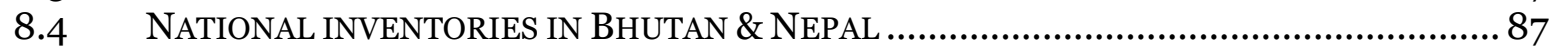

9 Acknowledgments ..........................................................................88

References ..........................................................................................90

Appendix 1: South Asian Nomination Strategy ............................................91

1 Introduction................................................................................ 93

2 South Asian nomination strategy: general issues .................................94

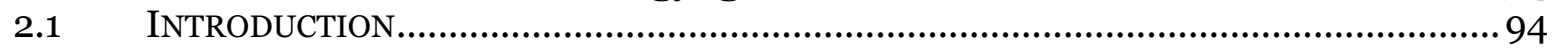

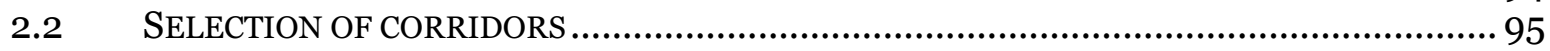

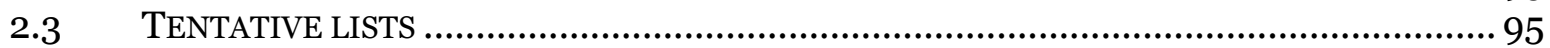

2.4 NATIONAL INVENTORIES AND CONTINUING RESEARCH ............................................96

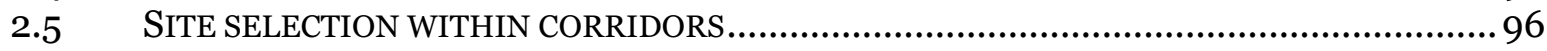

2.6 LINKING WITH EXISTING WORLD HERITAGE SITES................................................ 96

2.7 PROTECTION AND MANAGEMENT ............................................................................. 96 
3 Nomination strategy ........................................................................ 97

3.1 ROUTES FROM THE TIBETAN PLATEAU TO THE GANGETIC PLAIN VIA NEPAL ...............97

3.2 SOUTHERN TAKLAMAKAN TO NORTH-WEST INDIA (AND BEYOND) ..............................99

3.3 SOUTHWEST SILK ROADS: TEA AND HORSE ............................................................99

3.4 THE NORTHWEST FRONTIER ROUTES TO CENTRAL ASIA.......................................... 100

4 Comments on specific corridors .........................................................101

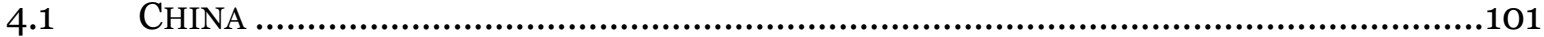

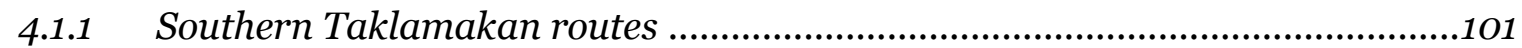

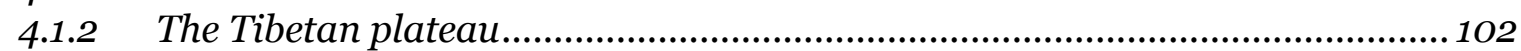

4.1.3 Yunnan \& Sichuan: the 'Southwest Silk Roads' ................................................. 102

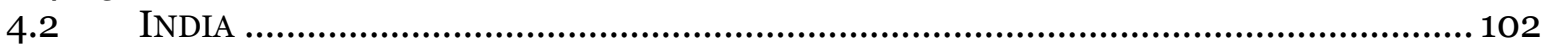

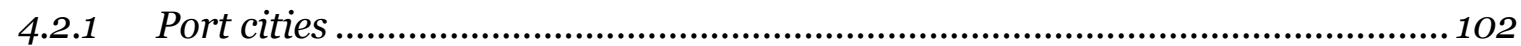

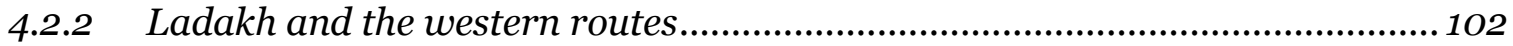

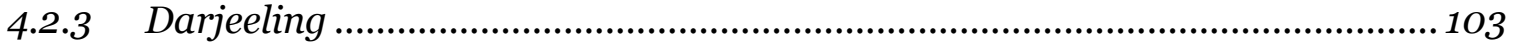

4.2.4 Routes along the Ganges ................................................................................... 103

4.2.5 North-south connections: around the Thar Desert to the ocean.........................104

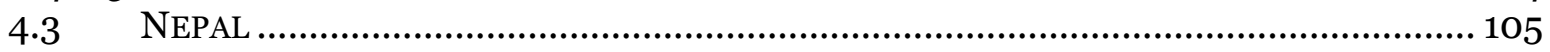

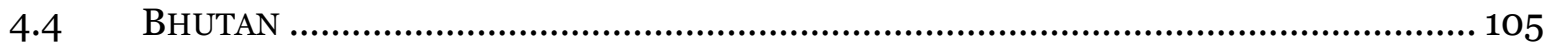

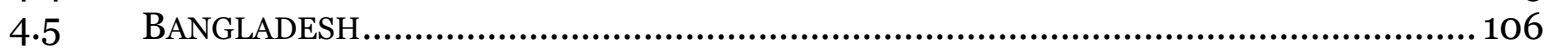

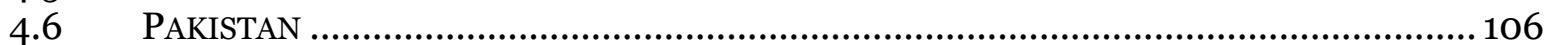

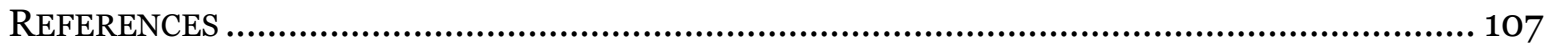

Appendix 2: Recommendations for the South Asian Silk Roads (2014) .......... 109

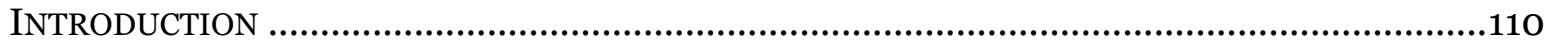

NATIONAL INVENTORIES AND CONTINUING RESEARCH .....................................................

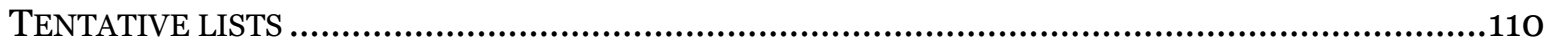

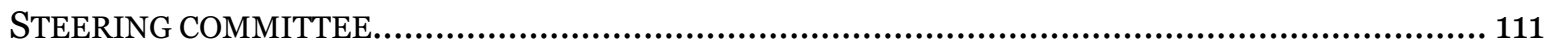

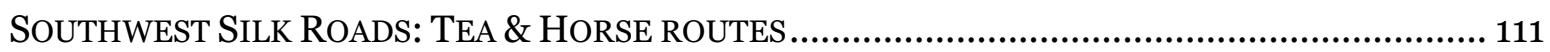

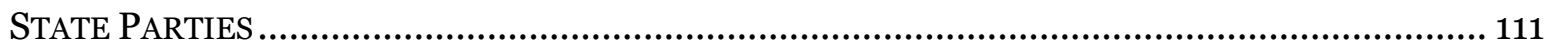

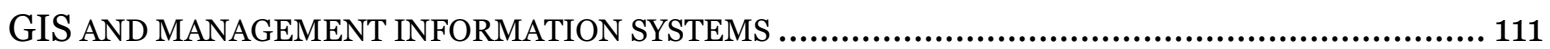

Appendix 3: Draft Action Plan in consideration of the submission deadline of 1 February 2018 of the first South Asian priority transnational heritage corridor(s) 113

Appendix 4: 'Almaty Agreement' 117 


\section{List of figures}

Figure 1. The Silk Roads corridors in South Asia, as identified in the original ICOMOS Silk Roads Thematic Study (Williams 2014).

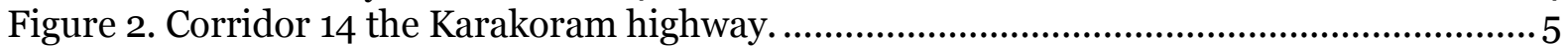

Figure 3. Corridor 20 along the southern fringes of the Taklamakan Desert. ..........................6

Figure 4. Corridors 38 \& 39 along the Ganges. ....................................................................... 7

Figure 5. Part of Corridor 40, between Lhasa the Gangiatic Plain............................................ 7

Figure 6. Corridors $41 \& 42$ between Tibet to India via central Nepal. .....................................8

Figure 7. Corridor 43 through the high Karakoram - Taklamakan Desert to Gujranwala, via

Sangju Pass, Leh and Srinagar.............................................................................................9

Figure 8. Corridor 52 Taxila to Indraprastha via Gujrat. Crucial route connecting with Corridor

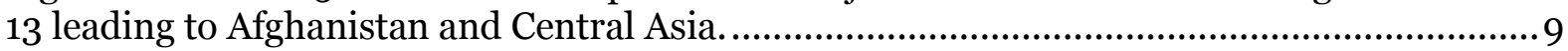

Figure 9. Corridors 48 \& 55 Indus Valley to the sea........................................................ 10

Figure 10. Delegates at the 2011 Ashgabat meeting. ............................................................. 13

Figure 11. Kakrebihar, near Surkhet, Nepal: $12^{\text {th }}$ century temple complex, demonstrating interplay of Hinduism and Buddhism. ..................................................................................17

Figure 12. Pillar stone (khambha), marking the route north of the Surkhet Valley, Nepal.... 18

Figure 13. Prof Roland Lin (UNESCO) and Yeshi Samdrup (DCHS) at Dochu La pass (3,116 m)

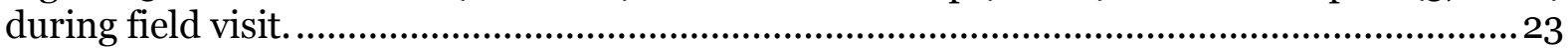

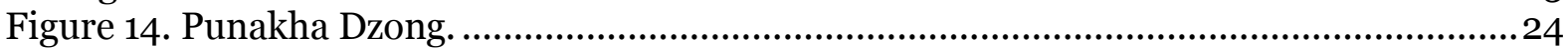

Figure 15. Entrance to Punakha Dzong (left) and inner courtyard (right).............................24

Figure 16. Complex carved and painted woodwork. Conserving this represents a major challenge in terms of maintaining traditional craft skills in timber preparation, carving and

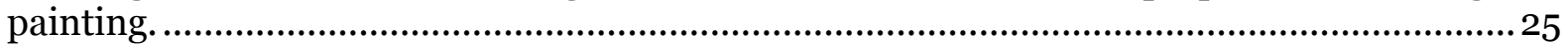

Figure 17. Historic images of Punakha Dzong, useful for assessing early modern modifications

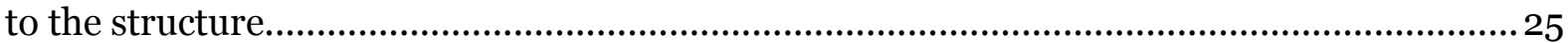

Figure 18. Tango Monastery, with a dramatic hillside setting. ..............................................26

Figure 19. Tango Monastery with an active monastic community....................................... 27

Figure 20. Simtokha Dzong: complex murals repainted to sustain their role for a living monastic community. .........................................................................................................2 27 Figure 21. Simtokha Dzong: the replacement of timbers, with some issues of timber preparation, and highlighting the need to maintain wood carving and painting skills.........28

Figure 22. Drukgyel Dzong. .............................................................................................28

Figure 23. Outer gatehouse: exterior (left) and interior (right), with temporary roof............29

Figure 24. The landscape context of the Dzong.......................................................................29

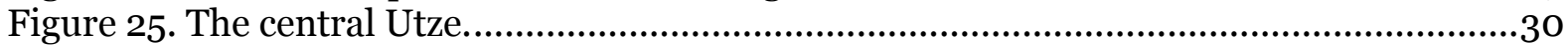

Figure 26. The outer works of Drukgyel Dzong, showing the difficulties of managing this large complex....................................................................................................................... 31

Figure 27. Meeting between His Excellency Damcho Dorji (Minister for Home \& Cultural Affairs, Royal Government of Bhutan), Roland Lin (UNESCO World Heritage Centre) and Tim Williams (University College London).

Figure 28. Indian tentative list sites (2010). ..................................................................... 33

Figure 29. Northeast India, including links to the Bay of Bengal, and its important ports, such as Chandraketugarh, Visakhapatnam and Chittagong (Bangladesh). ....................................34

Figure 30. Northwest India and Pakistan............................................................................ 34

Figure 31. The World Heritage Site of the Ajanta Caves, Maharashtra, India. The first Buddhist cave monuments at Ajanta date from the 2nd and 1st centuries BCE, but during the Gupta period (5th and 6th centuries $\mathrm{CE}$ ), richly decorated caves were added: masterpieces of Buddhist religious art (Photograph taken by Ashok [Freakyyash]. GNU Free Documentation License).

Figure 32. Students from UCL and other participating Universities at the cultural landscape

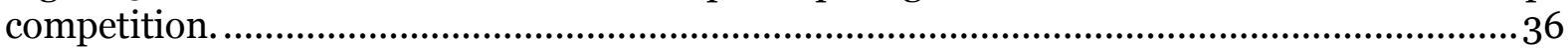

Figure 33. The workshop members outside the National Archive building ............................... 37

Figure 34. Examining 3D photographic software and scanning options. ................................ 41

Figure 35. Possible routes through and near Bhutan, based on later sites controlling mountain 
valleys and passes.

.42

Figure 36. Kathmandu sub-regional workshop on the nomination strategy for the South Asian

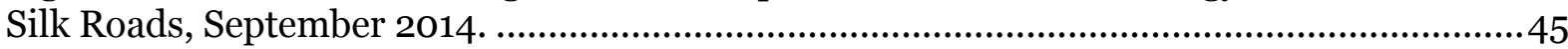

Figure 37. The participants at the Kathmandu sub-regional workshop on the nomination strategy for the South Asian Silk Roads, September 2014 ...................................................46

Figure 38. Routes through Nepal based on the comments of Mr Sukra Sagar Shrestha........54

Figure 39. The Kaligandaki Gorge: an example of the remote and rigged terrain of the mountain routes (Photographs Mr Sukra Sagar Shrestha). ....................................................54

Figure 40. Caves in Mustang (photograph Prof Susanne von der Heide) ..............................55

Figure 41. Ghemi, an outstanding example of the long walls organizing and controlling this landscape (Photograph Mr Sukra Sagar Shrestha).............................................................55 Figure 42. Stupa with Asokan pillar, at Vaishali, Bihar, India (Creative Commons AttributionShare Alike 2.5). . .56 Figure 43. The South Asian region with some of the main corridors under discussion during the workshop. .. 57 Figure 44. The participants at the 4th meeting of the Coordinating Committee of the Serial World Heritage Nomination of the Silk Roads, in Almaty, Kazakhstan: 23-27 November 2015.

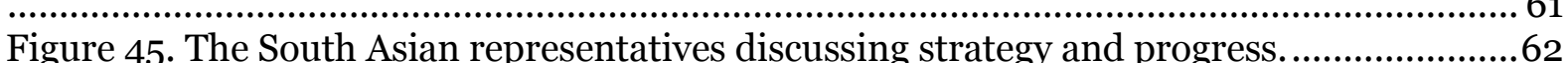

Figure 46. The Almaty meeting in progress...................................................................63

Figure 47. Sukra Sagar Shrestha describing to Christian Manhart, Suresh Suras Shrestha and Debendra Bhattarai the importance of a site along the route. .........................................65

Figure 48. The Lumbini-Mustang corridor (Google Earth). ................................................65

Figure 49. Sainamaina, Bitol: an intricate carved statute, possibly of Padmapani (Bodhisattva)

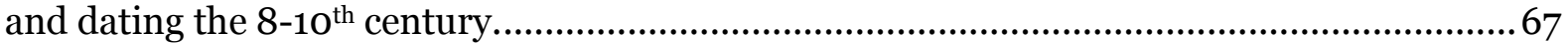
Figure 50. Argauli: locally managed irrigation systems. Debendra Bhattarai (DoA) is measuring the width of canal, while a local boy is managing the water flow, directing water from one field to another using lumps of soil.

Figure 51. Mustang-Lumbini corridor, Nepal: a rock shelter on the way from Beni to Jomsom may have been destroyed during road construction, but parts of a rock-hewn trail, in the stone cliff above the present road, still exists..................................................................................68 Figure 52. The ARCHES inventory system. A screenshot from the project website (http://archesproject.org/)................................................................................................ 71 Figure 53. Front page of ARCHES for Bhutan..................................................................... 77 Figure 54. Participants at the February 2016 workshop on National Heritage Inventories, held at the Office of Department of Culture, Thimphu, Bhutan......................................................78

Figure 55. Presentation session at the Bhutan workshop.......................................................79 Figure 56. Entering data into ARCHES for an historic resource in Bhutan, displayed against

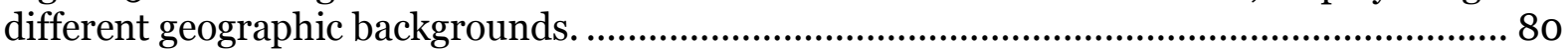

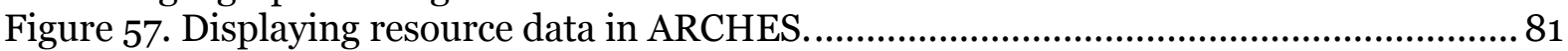

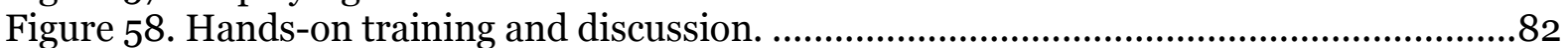

\section{Figures in Appendix 1:}

Figure 1. The corridors identified in the ICOMOS Thematic Study (Williams 2014)............94 Figure 2. The South Asian region and the principle route identified in the original Silk Roads Thematic Study.

Figure 3. Sites along the Tibetan Plateau and the three corridors through Nepal: the easternmost Kathmandu Valley (Corridor 40), the central (mid-western Nepal) route through Lo Manthang and Lumbini (Corridor 41) and the westernmost route including Jumla and

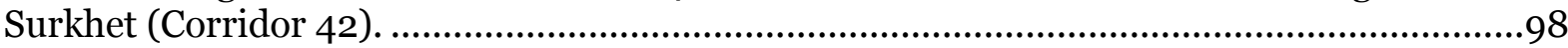

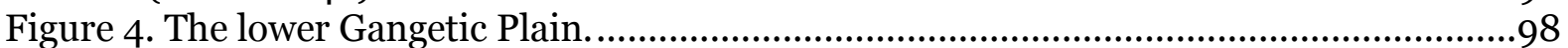

Figure 5. Southern Taklamakan to north-west India (and beyond)....................................99

Figure 6. Beginning to examine the routes between Yunnan and Sichuan (right), through Bhutan and Myanmar, to India and Bangladesh.................................................................100

Figure 7. The northwest frontier routes to Central Asia..................................................... 101

Figure 8. The Southern Taklamakan corridor................................................................. 101 
Figure 9. Through the high Karakoram - from the southern Taklamakan through Srinagar, Leh and Sangju Pass to the Gangetic Plain. 103 Figure 10. The Indo-Gangetic Plain: the fertile plain of the Ganges and Indus river systems. 104 Figure 11. The corridors through the Gangetic Plain: the wide fertile river system of the Ganges enabled sites to develop over a broad area and there were multiple routes across this landscape. At present two corridors (Corridors 38 and 39) have been defined, encompassing the main urban developments and monuments, but a single wider corridor probably may be more appropriate, linking into the network of north-south routes across the Himalayas. ..104 Figure 12. The routes (not yet mapped) south-westward to the Ocean. ................................ 105

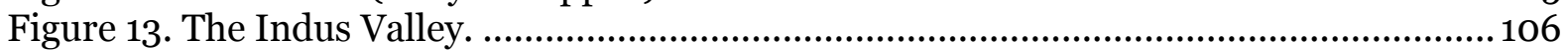




\section{Foreword by Dr Roland Lin Chih-Hung}

Project Officer,
UNESCO/Republic of
Korea Funds-in-Trust
project "Support for the
Preparation for the World
Heritage Serial
Nomination of the Silk
Roads in South Asia"; Asia
and the Pacific Unit, World
Heritage Centre, UNESCO

A $\mathrm{s}$ the largest cultural routes network in the history of humankind, the Silk Roads present major potential for inscription on the World Heritage List. Over the past four decades, UNESCO has launched a number of ambitious initiatives aimed at reinforcing dialogue and research along the Silk Roads. The Integral Study of the Silk Roads: Roads of Dialogue (UNESCO 1988-1997) further reinforced the concept of a "common heritage and pluralistic identity". Since 2003, the UNESCO World Heritage Centre has played a key role in the coordination of the serial transnational World Heritage nomination of the Silk Roads, initiated by five Central Asian countries and China. As a transnational serial nomination, the Silk Roads World Heritage nomination project is crucial to enhance international exchanges and cooperation efforts towards effective sustainable heritage conservation and management. Since cultural heritage serves as a living legacy that every society takes from its past, each generation therefore holds the responsibility to preserve it and pass it on to future generations. The Silk Roads, which stretch across the length of the Asian continent, possess some of the region's most outstanding and valuable heritage, and their disappearance would be an irreplaceable loss to humanity.
Within the framework of the Global Strategy for a Representative and Balanced World Heritage List, adopted by the World Heritage Committee in 1994, State Parties such as China, Kazakhstan, Kyrgyzstan, Tajikistan, Turkmenistan, and Uzbekistan have been working with the UNESCO World Heritage Centre on the serial and transnational nomination of the Silk Roads. In this framework, UNESCO has organised a number of regional and sub-regional workshops and four meetings of the Coordinating Committee of the Serial World Heritage Nomination of the Silk Roads (May 2009, Xian, China; May 2011, Ashgabat, Turkmenistan; September 2012, Bishkek, Kyrgyzstan; and November 2015, Almaty, Kazakhstan). The Silk Roads nomination project now includes 14 countries (Afghanistan, China, India, Iran, Japan, Kazakhstan, Kyrgyzstan, Nepal, Pakistan, the Republic of Korea, Tajikistan, Turkey, Turkmenistan and Uzbekistan) that are members of the Silk Roads World Heritage Nomination
Intergovernmental
Coordinating Committee, as well as Bhutan as an observer. The 'Heritage Corridor' nomination approach was set out in the ICOMOS Silk Roads Thematic Study presented at the 2011 Ashgabat meeting (updated and published in 2014: Williams 2014). Following the UNESCO/Japanese Funds-in-Trust (FiT) Project "Support for documentation standards and procedures of the Silk Roads World Heritage Serial and Transnational Nomination in Central Asia" (February 2011 to February 2015), the Chinese authorities, together with ICOMOS, the International Institute for Central Asian Studies (IICAS - a UNESCO Category 2 Centre based in Samarkand, Uzbekistan) and the ICOMOS International Conservation Centre - Xi'an (IICC-Xi'an), have supported the development of two Silk Roads nomination dossiers by China and Central Asian countries. Two serial and transnational nominations for the Silk Roads were submitted in 2013. "The Silk

Roads: the Routes Network of Chang'an - Tian-shan Corridor," was 
jointly prepared by China, Kazakhstan and Kyrgyzstan, and consisted of 33 serial components (22 from China, 8 from Kazakhstan and 3 from Kyrgyzstan): it was inscribed on the World Heritage List, on the basis of criteria (ii), (iii), (v) and (vi), at the 38th session of the World Heritage Committee (Doha, Qatar, June 2014). The second nomination dossier, which concerned the Penjikent-SamarkandPoykent Corridor, was jointly submitted by Tajikistan and Uzbekistan and was referred back to the States Parties in order for them to strengthen and improve the documentation, with advice from ICOMOS and the World Heritage Centre.

However, the Silk Roads nomination process has not yet begun in earnest in South Asia. A serial and transnational nomination for the Silk Roads in South Asia would contribute to the overall goal of protecting key segments of this important heritage route and would advance the role of culture in sustainable development in South Asia. The World Heritage Centre, in close collaboration with the UNESCO Kathmandu and New Delhi offices, has now implemented the extra-budgetary project "Support for the Preparation for the World Heritage Serial Nomination of the Silk Roads in South Asia", within the framework of the UNESCO/Republic of Korea FiT (June 2013 to August 2016, USD 200,000, including $13 \%$ programme support). The goal of this project is to provide and coordinate a cooperation platform for China, Nepal, India and Bhutan, focusing on a network of routes in this sub-region.

The objective of assisting the relevant South Asian States Parties in the preparation of a serial and transnational nomination (or nominations) for the Silk Roads was to be achieved through four main activities:

(1) Consultation mission(s) and training workshop(s);

(2) A sub-regional workshop in Nepal (Kathmandu, 23-24 September 2014);

(3) The drafting of a World Heritage Nomination Strategy and Guidance for South Asia Silk Roads. This was drafted by Tim Williams (Institute of Archaeology, University College London, and author of the ICOMOS Silk Roads Thematic Study), in close collaboration with the relevant specialized Agencies of the South Asian countries and the UNESCO World Heritage Centre;

(4) The 4th meeting of the Coordinating Committee of the Serial World Heritage Nomination of the Silk Roads (24-25 November 2015, Almaty, Kazakhstan).

The successful inscription of "The Silk Roads: the Routes Network of Chang'an - Tian-shan Corridor" demonstrates that this serial and transnational nomination process provides a valuable approach for national capacity building, as well as a means to increase diversity and progress towards a balanced and representative World Heritage List. The property's use of both the sustained subregional cooperation and the ongoing international cooperation is currently being replicated in the South Asian Silk Roads (China, India, Nepal and Bhutan) and again in Central Asia through a new nomination project on Silk Roads: Fergana-Syr Darya Corridor (under preparation by Kyrgyzstan, Uzbekistan, Kazakhstan, Tajikistan). The approach has the potential to be a model for capacity building and the preparation of serial and transnational nominations worldwide.

The UNESCO/Republic of Korea FiT extrabudgetary project "Support for the Preparation for the World Heritage Serial Nomination of the Silk Roads in South Asia" was important to reinforce the capacity of national authorities in each of the South Asian countries, particularly Bhutan and Nepal, for the documentation and survey of archaeological and architectural sites and the digitalization of archives. At subregional level, the project also helped set up transnational documentation strategies and methodologies, and information sharing. The progress achieved with this project demonstrates the importance of adequate material resources and the benefits of international cooperation: transnational and serial nominations require the active participation of all States Parties involved as well as the cooperation of outside international experts. The project also showed that significant investment in technological resources and strong support for local capacity-building are further 
essential elements in transnational and serial nominations, particularly when a project involves approaches and techniques that are new to the States Parties involved. By involving all States Parties in this challenging serial transnational property, the steps taken towards transnational cooperation, the technological investments and the local capacity building carried out as part of the project's implementation help to ensure that eventually, these sites can become sustainable, effectively managed World Heritage properties.

Step-by-step, the World Heritage Silk Roads nominations projects aim to cover relevant portions of the many vitally important trans-Himalayan routes that connected western China (Yunnan, Sichuan and Xingjian) and Central Asia to South Asia, often via the Tibetan plateau, (these are discussed in Section 1).

The reader will learn from this Final Technical Report what steps have been taken as part of the on-going preparation of the World Heritage serial nomination of the Silk Roads in South Asia. Additionally, the four annexes to this Report present the initial results of the project:

1) South Asian Silk Roads: Draft Serial and Transnational World Heritage Nomination Strategy;

2) Recommendations for the South Asian Silk Roads;

3) Draft Action Plan in consideration of the submission deadline of 1 February 2018 of the first South Asian priority transnational heritage corridor(s) (adopted at the sub-regional workshop, 23-24 September 2014, Kathmandu, Nepal);

4) The "Almaty Agreement" (adopted in the 4th meeting of the Coordinating Committee of the Serial World Heritage Nomination of the Silk Roads, 24-25 November 2015, Almaty, Kazakhstan).

I would like to take this opportunity to extend my heartfelt appreciation to all the participating Asian countries that pursued this complex intercultural project despite their differences in political systems, administrative and legal frameworks, professional capacity and even languages. Through this innovative approach of serial and transnational cooperation, these nations now have a better understanding of each other. The commitment they have made will serve to promote future regional and international cooperation towards promoting cultural diversity and the sustainable development of the region.

I would also like to express my appreciation to the implementing partners:

- The Department of Archaeology (DoA) of Nepal;

- The Archaeological Survey of India (ASI);

- The Division for Conservation of Heritage Sites (DCHS) of the Department of Culture of the Ministry of Home and Cultural Affairs, Royal Government of Bhutan;

- The State Administration of Cultural Heritage (SACH), China; ICOMOS International;

- The ICOMOS International Conservation Centre - Xi'an (IICCX'ian);

- The team of Tim Williams, Institute of Archaeology, University College London, UK.

UNESCO would also like to express its sincere gratitude to all those partners that have supported and continue to support this project, and in particular the Donor, the Cultural Heritage Administration (CHA) of Korea, for their financial contributions through the UNESCO/Republic of Korea FiT, in cooperation with the World Heritage Centre.

Finally, the World Heritage Centre would like to commend the contributions and strong support received from Bhutan, China, India and Nepal, as these participating countries helped ensure the success of the initial phase of the South Asian Silk Roads nomination process. 


\section{The Silk Roads in South Asia}

\subsection{Routes and corridors}

Numerous vitally important trans-Himalayan routes connected western China (Yunnan, Sichuan and Xingjian) and Central Asia, many via the Tibetan plateau, to South Asia. These routes were of fundamental importance to the development of the region (Fisher 1992; Rizvi 2000; Tong 2013). These broadly north-south routes connected with largely east-west routes, such as those along the southern Taklamakan Desert and those through the Gangetic Plain.

Four principal networks of routes can be defined (Figure 1):

- Routes from the Tibetan Plateau to the Gangetic Plain via Nepal

- Southern Taklamakan to north-west India (and beyond)

- Southwest Silk Roads: tea and horse

- The northwest frontier routes to Central Asia

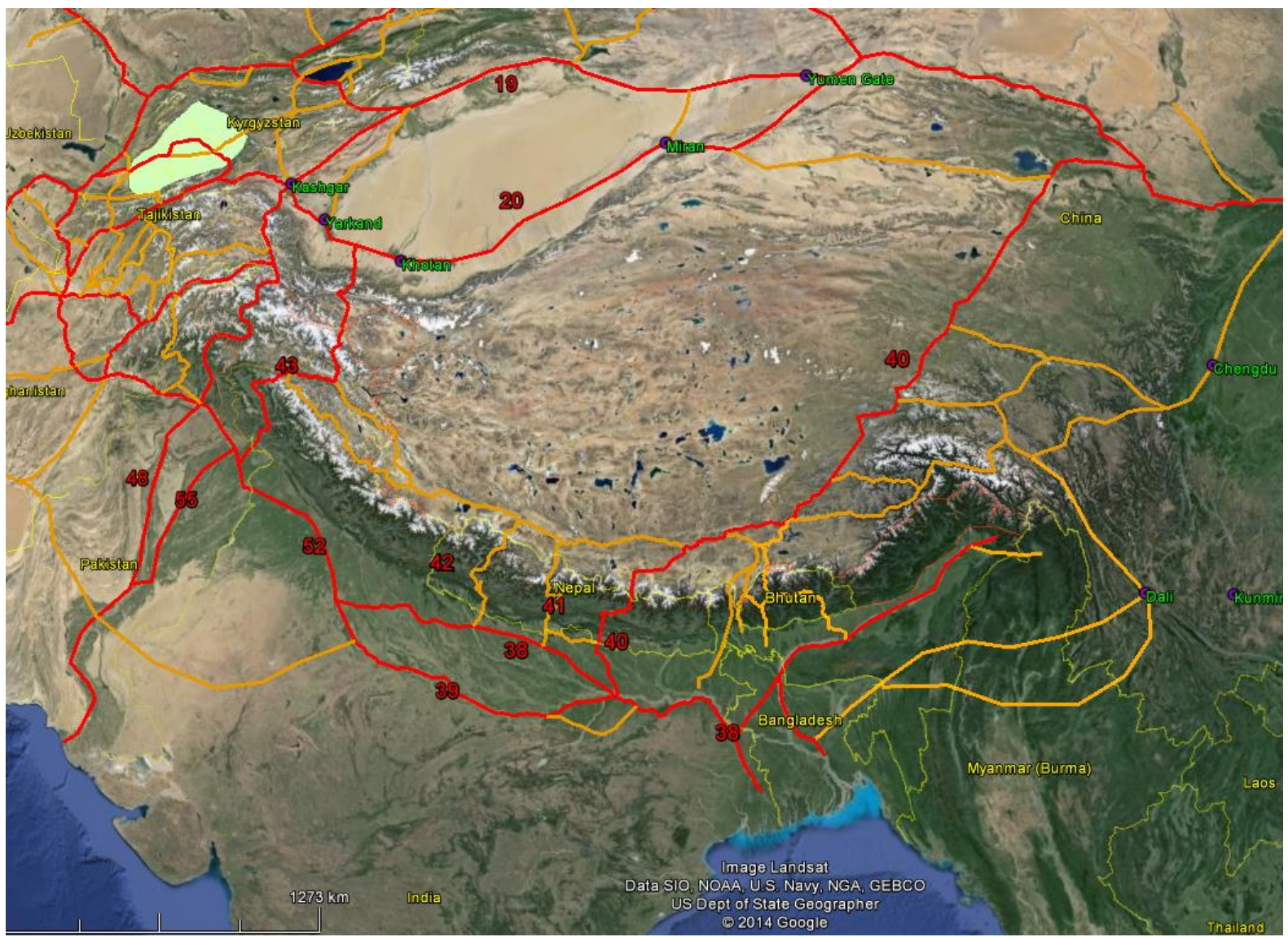

Figure 1. The Silk Roads corridors in South Asia, as identified in the original ICOMOS Silk Roads Thematic Study (Williams 2014).

The main corridors defined allocated in the original ICOMOS Silk Roads Thematic Study (Williams 2014). The corridors with the South Asian study area ${ }^{1}$ were very different: they saw very different scales of traffic, and had different chronologies of use. However, all were important in developing local cultures and polities, and were instrumental in the movement of ideas, goods and peoples. Each was vital in the development of specific polities and/or empires.

${ }^{1}$ These are discussed, in more detail, in the South Asian Silk Roads nomination strategy (reproduced in this report as Appendix 1). 
The main corridors were:

Corridor 14 (China \& Pakistan): the Karakoram highway (via the Khunjerab and Wakhir Passes) - Tashkurgan to Taxila. Length c $750 \mathrm{~km}$. High mountain passes and valleys. Links between China and South Asia, formalised under the Kushan Empire, were accessed chiefly through this corridor.

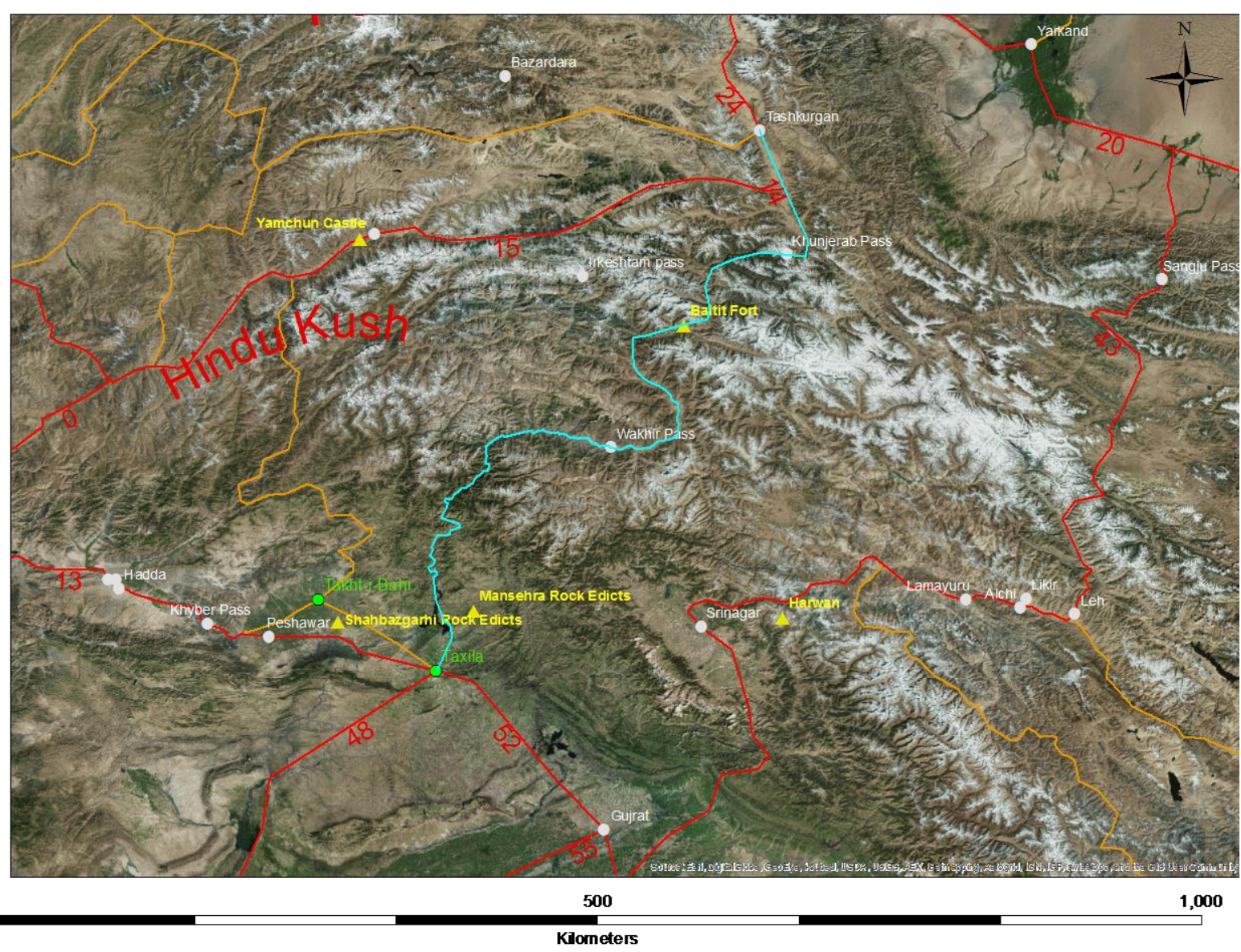

Figure 2. Corridor 14 the Karakoram highway.

Corridor 20 (China): The oases route along the southern edge of the Taklamakan Desert: Loulan to Kashgar, via Miran, Charchan, Khotan and Yarkand. Length around $1,500 \mathrm{~km}$. Southern desert fringe punctuated with seasonal oases. Important landscape for control of routes to south and west. Very different adaptations, chronologies and empire systems to the northern routes around the Taklamakan Desert (Corridor 19). 


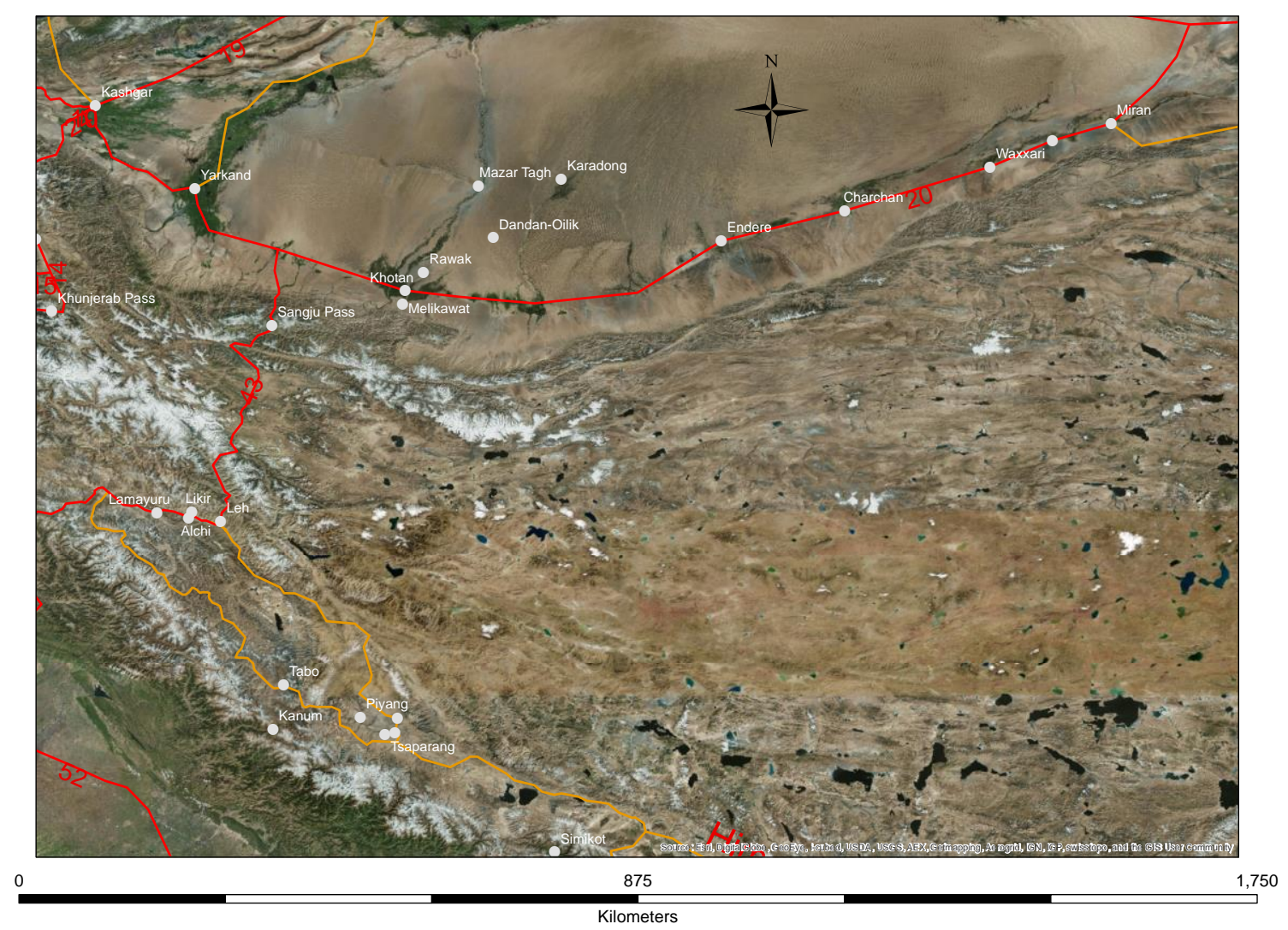

Figure 3. Corridor 20 along the southern fringes of the Taklamakan Desert.

Corridors 38 \& 39 (India): Down to the Ganges: Indraprastha to Chandraketugarh. Length around $1,400 \mathrm{~km}$. These corridors, reflecting movement either side of the Ganges, encompass a large fertile areas, fed by many system of rivers, and used for agricultural purposes. These have important connections to the mountain routes in the north and to the sea, and maritime routes, in the east. The corridors, which have long been the seat of power for many regimes and empires, are known for their development of learning and religion, major urban developments, and water management.

Corridor 40 (India, Nepal \& China): The High Tibetan Plateau and down to the Ganges: Lhasa to Pataliputra, through the Kathmandu Valley. Length around $980 \mathrm{~km}$. This corridor, which encompasses of major mountain valleys and passes. Complex empire systems, with periods of both isolation and major connectivity; local adaptations to climate and major religious and urban outcomes. 


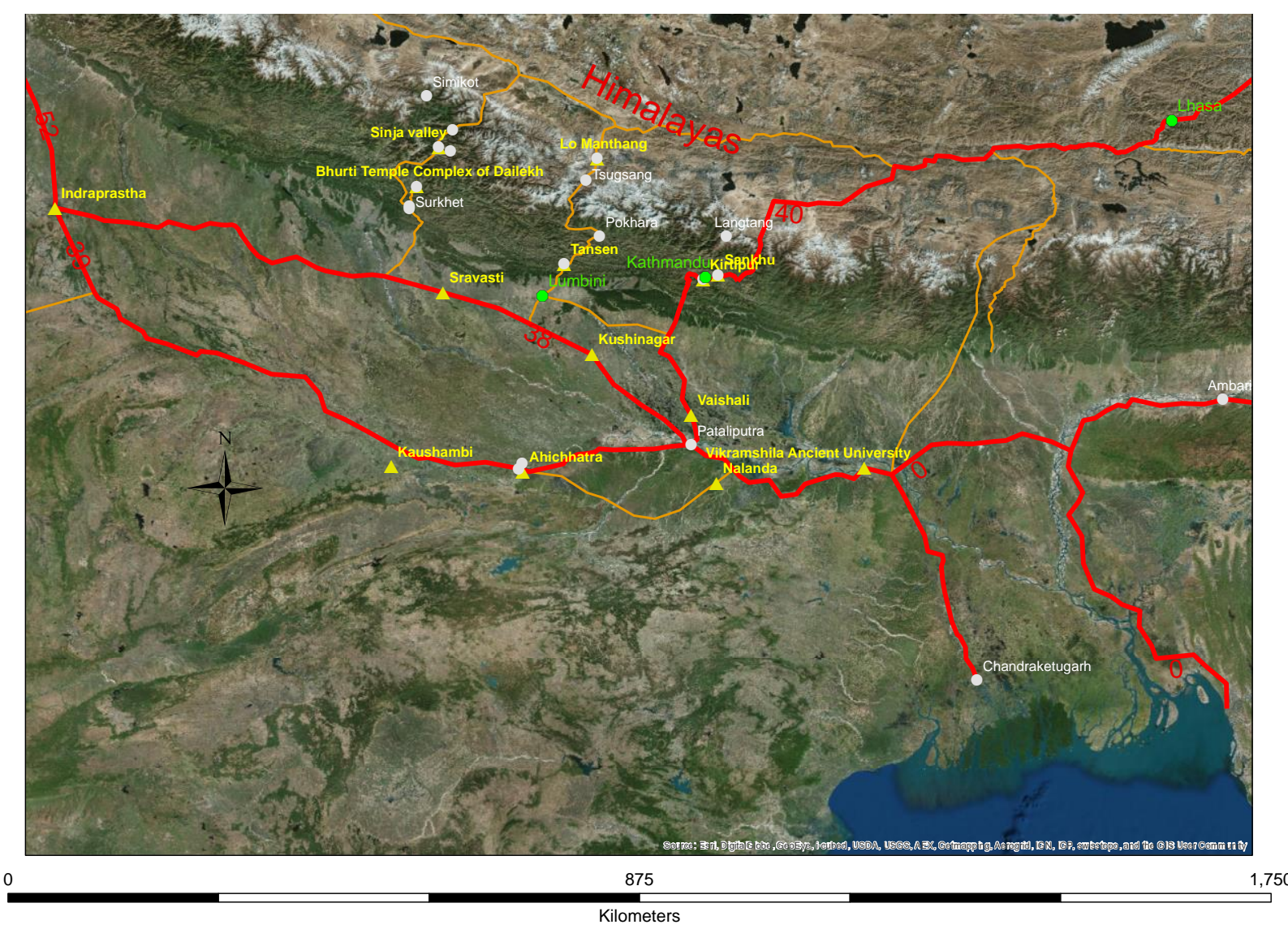

Figure 4. Corridors 38 \& 39 along the Ganges.

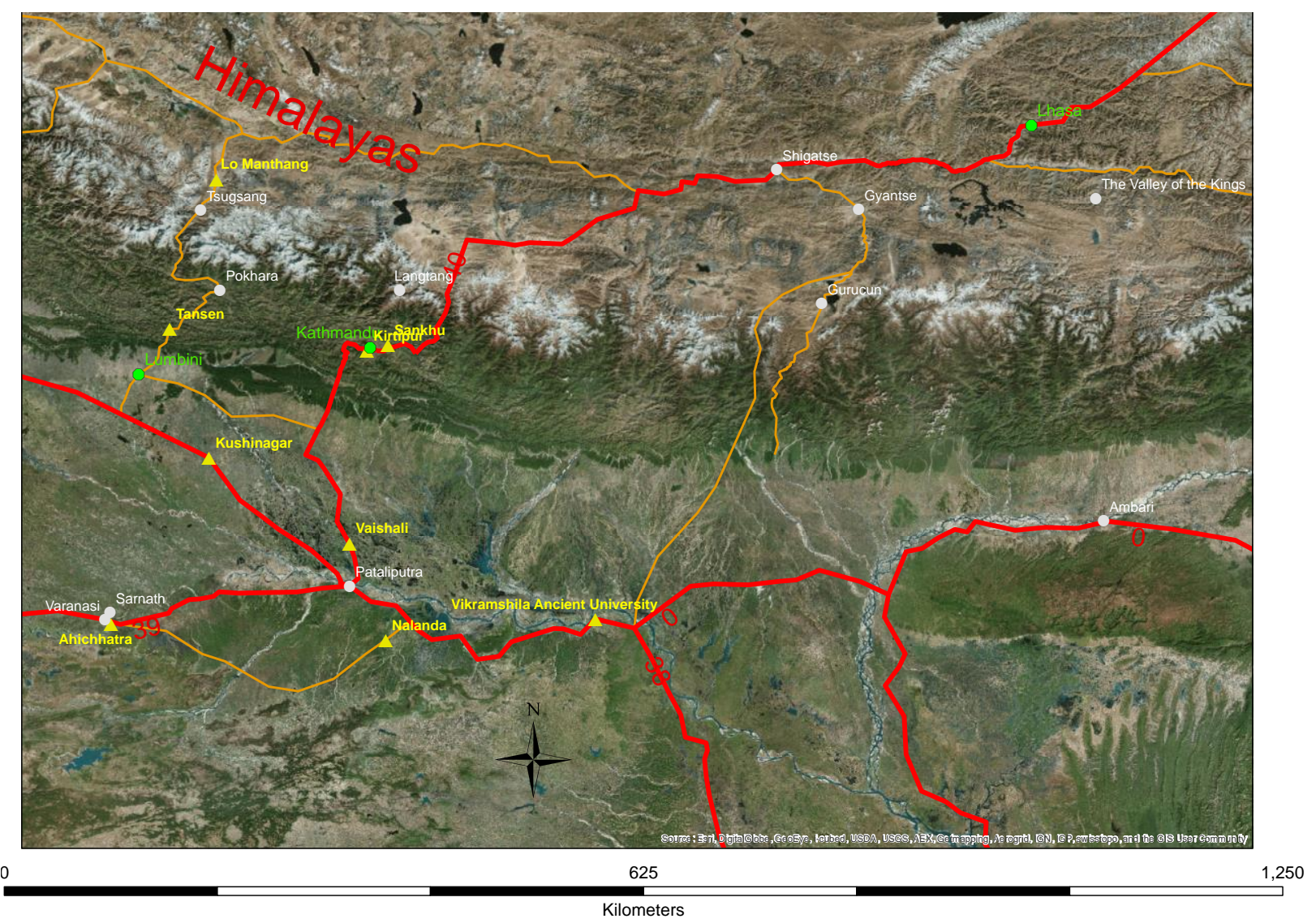

Figure 5. Part of Corridor 40, between Lhasa the Gangiatic Plain. 
Corridor 41 (Nepal, India \& China): between Lhasa and the Gangiatic Plain, via the Lumbini-Mustang segment of the corridor in Nepal. Length about $389 \mathrm{~km}$. The corridor includes high Himalayan mountain passes, steep trails, and fertile high valleys. During the Kathmandu sub-regional workshop (Section 4.7), Nepal suggested that they would focus on the Lumbini-Mustang corridor as a transnational nomination priority.

Corridor 42 (India, Nepal \& China): Valleys and Mountains (Western Central Nepal): between Lhasa and the Gangiatic Plain via Sinja Valley and Surkhet. Length about $357 \mathrm{~km}$. High Himalayan mountain passes, small trails and fertile high valleys, a testimony to the adaption to mountain routes, with pillar stone markers, forts and waystations showing remarkable architectural control over a difficult terrain. These corridors are also home to an important blend of Hindu and Buddhist temples and iconography (e.g. Kakrebihar).

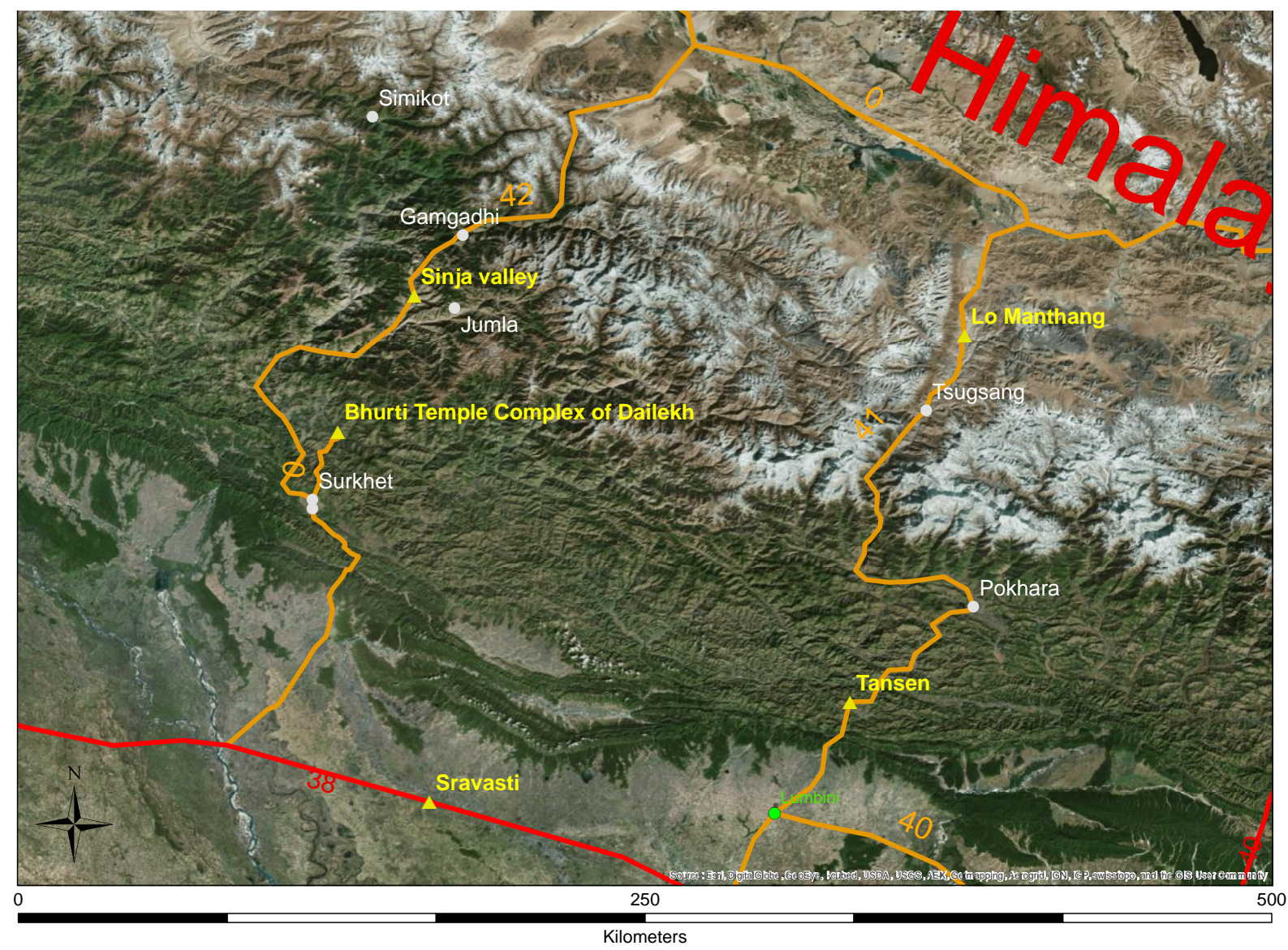

Figure 6. Corridors $41 \& 42$ between Tibet to India via central Nepal.

Corridor 43 (China \& India): through the high Karakoram - Taklamakan Desert to Gujranwala, via Sangju Pass, Leh and Srinagar. Length around 1,100 km. Winding mountain routes, with significant climatic and seasonal issues of adaptation. Complex adaptation to harsh condition, producing unique architecture, cultural contacts and empire/political controls.

Corridor 52 (India \& Pakistan): Taxila to Indraprastha via Gujrat. Length c. $775 \mathrm{~km}$. Crucial route connecting with Corridor 13 leading to Afghanistan and Central Asia. 


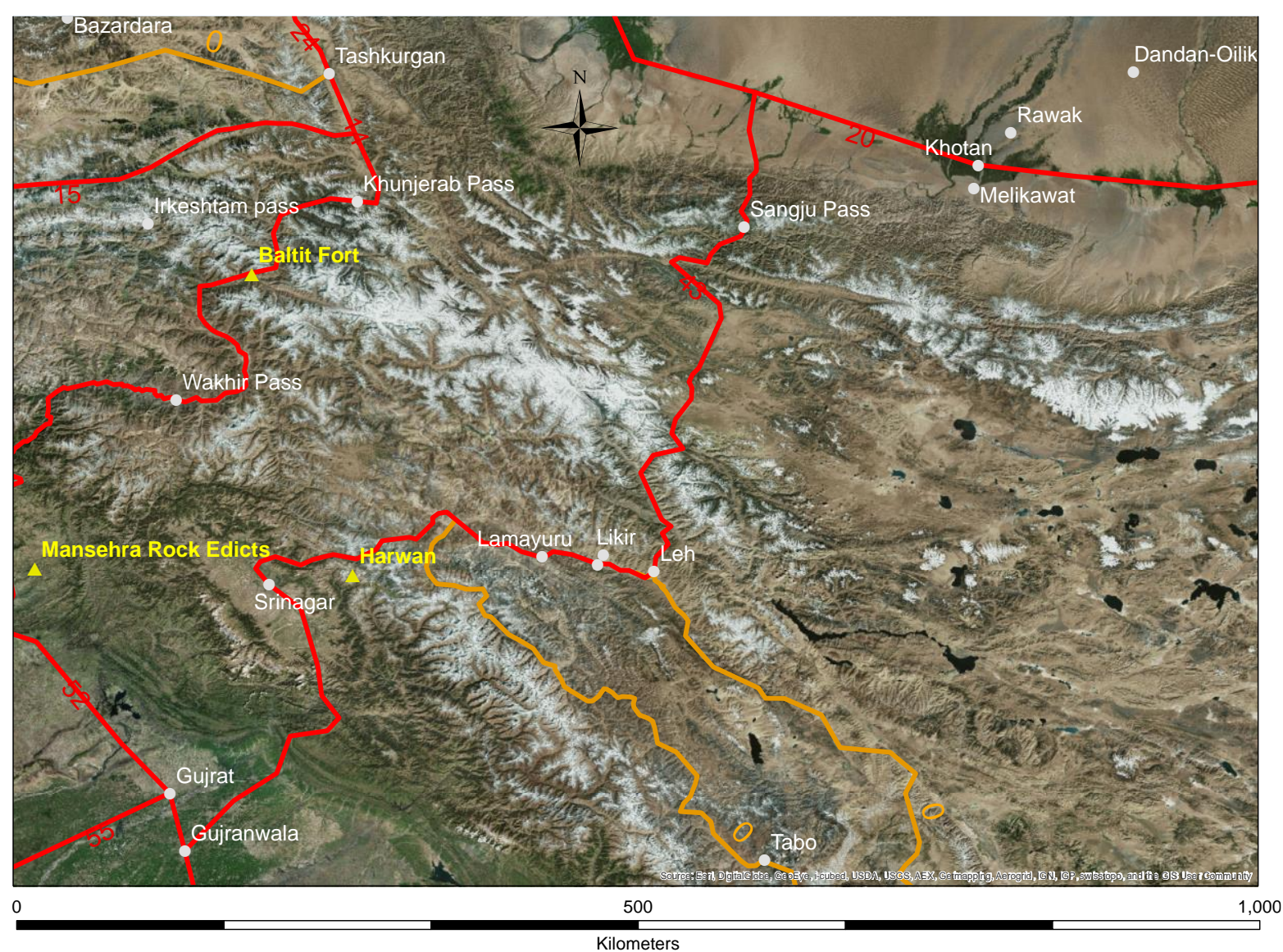

Figure 7. Corridor 43 through the high Karakoram - Taklamakan Desert to Gujranwala, via Sangju Pass, Leh and Srinagar.

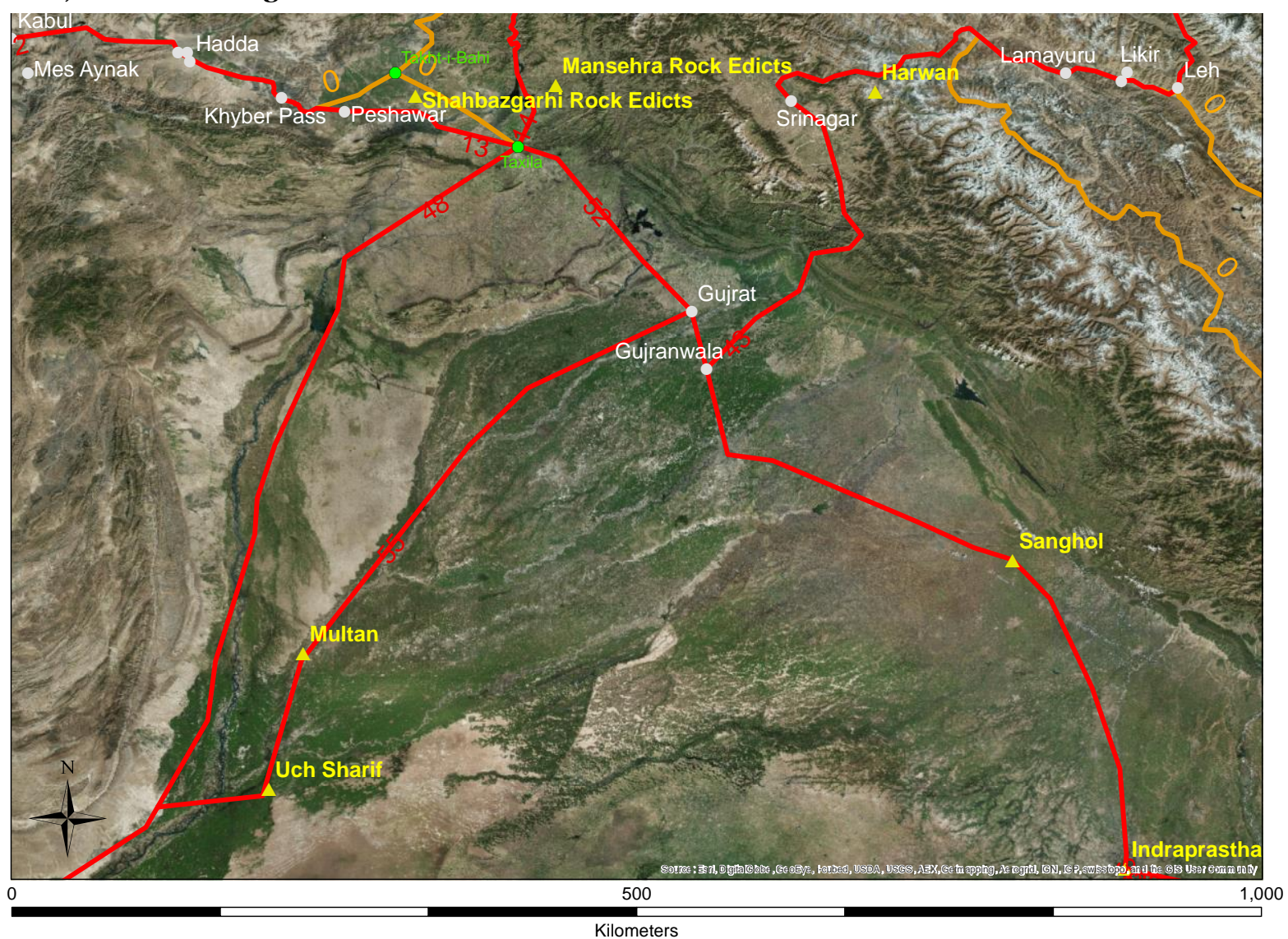

Figure 8. Corridor 52 Taxila to Indraprastha via Gujrat. Crucial route connecting with Corridor 13 leading to Afghanistan and Central Asia. 
Corridors 48 \& 55 (Pakistan): The Indus Valley - Taxila and Gurjat to Banbhore, via Multan, Thatta, etc. Length c $1,300 \mathrm{~km}$. Strategic routes connecting to the coast, linking with important early maritime connections. Could include crucial connections to Jaisalmer in India.

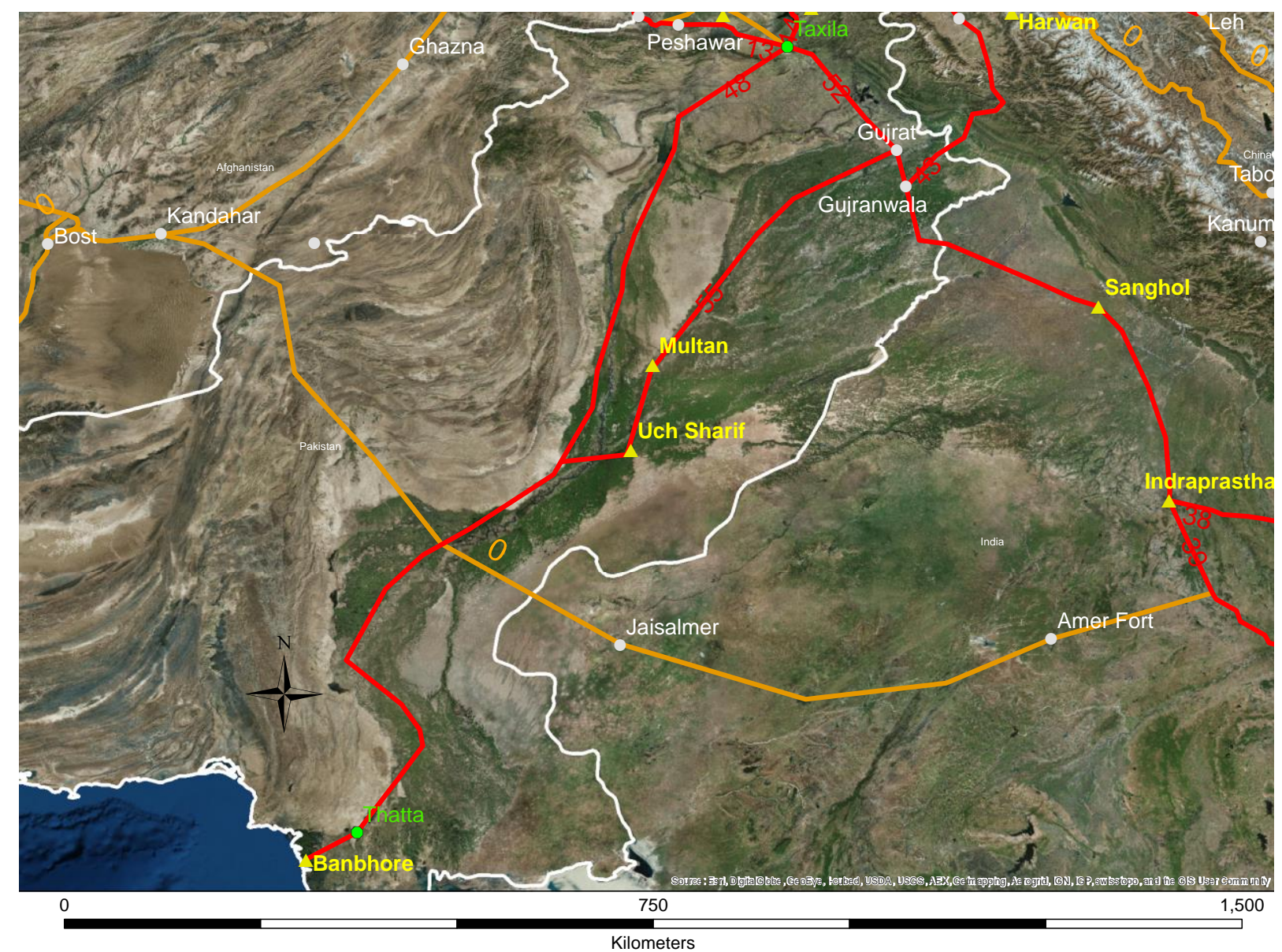

Figure 9. Corridors 48 \& 55 Indus Valley to the sea. 


\subsection{Trade, exchange and empires}

As with other parts of the Silk Roads, the balance between trade, elite exchange, and the impacts of travel and contact will need to be explored within South Asia. These are often intermeshed: Aihwa Ong's work (1999) discussed how travellers can be crucial transnational actors in the making of new economies, and how individual agency is crucial in the large-scale flow of people, images, and cultural forces across borders. Takeshi Hamashita, for example, noted that in the 14th-17th centuries "under the tribute-envoy system, a tributary state sent periodic tribute missions to the Chinese capital, and each time the ruler of a tributary state changed, the Chinese emperor dispatched an envoy to officially recognize the new ruler. This tributary relationship was at the same time a political, economic, and trade relationship. ... This tribute trade was not limited to Chinese merchants from East and Southeast Asia; Indian, Muslim, and European merchants also participated, confirming the link among coastal ports" (Hamashita 2011, 125). As Appadurai (1986) argued, the 'total trajectory' of commodities (from production, through exchange and distribution, to eventual consumption) involves different stages, and is enmeshed in complex intersections of economic, political, and cultural factors.

This is not to say that trade was unimportant. The trade goods passing along these various routes comprised tea, salt, spices, cashmere wool, musk, silk, metals and many other goods. Silk was only one component of the wide variety of trade goods moved (Williams 2014, 6-11). The movement of ideas and beliefs is also vital to understanding the impact of the Silk Roads on the region. In South Asia the impact of Buddhism, and its spread and interaction, cannot be underestimated (e.g. Akasoy et al. 2011; Elverskog 2010; Fogelin 2005; Neelis 2011; Wong \& Heldt 2014; Wriggins 2004).

The South Asian region also highlights the interconnection of land and sea routes in coastal zones, which encompass crucial articulations in systems of production, supply and redistribution. The initial thematic study (Williams 2014) raised questions of the interrelationship between land routes and port cities, an issue that was already very evident within the Indian subcontinent. The relationship between hinterlands, long distance land routes, and ports (the port-catchment nexus) are a vital part of the complex narrative of the Silk Roads. Maritime exchange between East Asia, China and Southeast/South Asia was conducted through a very large number of regional and local ports. The complexity of understanding these networks should not be under-rated. Sea routes are certainly attested from the Han dynasty onwards: for example, materials found in the Hepu tombs, on the south coast of Guangxi Zhuang autonomous region, bordering the Gulf of Tonkin, China, demonstrate the range and geographic spread of material, including did semi-precious beads from India and ceramics from the Parthian Empire (Zhaoming 2014). Complex interactions across the region are well known in the later historic periods (for example, see Tagliacozzo \& Chang 2011), but the earlier development of these needs further research.

\subsection{Corridor selection}

The selection of corridors to comprise any nomination strategy for South Asia needs to reflect the complexity of the societal responses to:

- The environmental and geographic nature of the area: with high plateaus, mountain passes, high mountain valleys, wide fertile river deltas, etc.;

- The empire system, polities and religions which developed through the interaction with, and control of, the Silk Roads. 


\section{Background: UNESCO Silk Roads serial trans- national nomination project}

\subsection{The development of the project}

In 1994 the World Heritage Committee launched the Global Strategy for a Representative, Balanced and Credible World Heritage List ${ }^{2}$. The aim of this was to ensure that the world's cultural and natural diversity was fully reflected in World Heritage List. Within this context, Central Asia was recognised as one of the most under-represented regions on the World Heritage List (ICOMOS 2002) and strategies for 'filling the gaps' in global representivity emphasised this (ICOMOS 2004). From an even earlier stage UNESCO had recognised the importance of the Silk Roads for intercultural exchange and the wealth of cultural heritage sites that it encompassed (UNESCO 1988). As a result, following the filling the gaps strategy, UNESCO proposed the development of a serial World Heritage trans-national nomination project for the Silk Roads, both a tool for fostering international collaboration and helping to address this lack of representation.

In 2006 a draft concept paper for the Serial Nomination of the Silk Roads was developed (Cleere 2006). This was revised and updated in 2007 and 2008 at UNESCO Sub-Regional Workshops (UNESCO 2007; UNESCO 2008), and was approved by the five participating countries: the Republics of Kazakhstan, Kyrgyzstan, Tajikistan, and Uzbekistan and the People's Republic of China.

A Coordinating Committee on the Serial World Heritage Nomination of the Silk Roads was established in the meeting in Almaty, 2009, to oversee the preparation of nominations and the implementation of management systems for individual Silk Roads sites. The first Coordinating Committee meeting took place in Xi'an in 2009, which requested ICOMOS to commission a Thematic Study in collaboration with UNESCO.

\subsection{ICOMOS Thematic Study}

In 2011 ICOMOS were commissioned by UNESCO to undertake a thematic study of the Silk Roads. The aim of this study was to provide an analysis of sites along the Silk Roads that could be used by States Parties participating in the Serial transnational World Heritage nominations of the Silk Roads as a basis for comparative analyses when nominating series of sites.

The final version of the thematic study was published in 2014 (Williams 2014), in advance of the first serial trans-boundary nominations to the World Heritage committee in Doha in June 2014 .

\subsection{Silk Roads nomination strategy}

The second Coordinating Committee meeting took place in Ashgabat, from 3 to 6 May 2011. This meeting was jointly organized by the UNESCO World Heritage Centre, UNESCO Office in Tehran, the Ministry of Foreign Affairs of Turkmenistan, the National Commission of Turkmenistan for UNESCO, and the Ministry of Culture, TV and Radio Broadcasting of Turkmenistan. This meeting brought together more than fifty representatives from twelve countries: Afghanistan, China, India, Iran, Japan, Kazakhstan, Republic of Korea, Kyrgyzstan, Nepal, Tajikistan, Turkmenistan and Uzbekistan, as well as experts from UNESCO, ICOMOS, 
the International Institute for Central Asian Studies (IICAS), University College London, and the Raymond Lemaire International Centre for Conservation, the University of Leuven.

The meeting discussed progress of the nomination process and reviewed the strategy proposed by the ICOMOS Thematic Study on the Silk Roads. The participants of the meeting adopted the Ashgabat Agreement 3 , which agreed, in principle, to adopt the heritage corridor approach, while recognising the need for further technical evaluation and clarification of the nomination process. It also sought to establish an overall Silk Roads World Heritage nomination framework, reflecting the new guidance on serial trans-boundary nominations arising from the International World Heritage expert meeting on serial nominations and properties in Ittingen, Switzerland, February, 2010. The Central Asian countries and China, agreed to establish the priorities for transnational corridors for the first phase of the Silk Roads nomination process. The meeting also agreed to reactivate the existing Expert Group of representatives from Central Asia and China, in collaboration with the IICC-Xi'an, Secretariat of the Coordinating Committee.

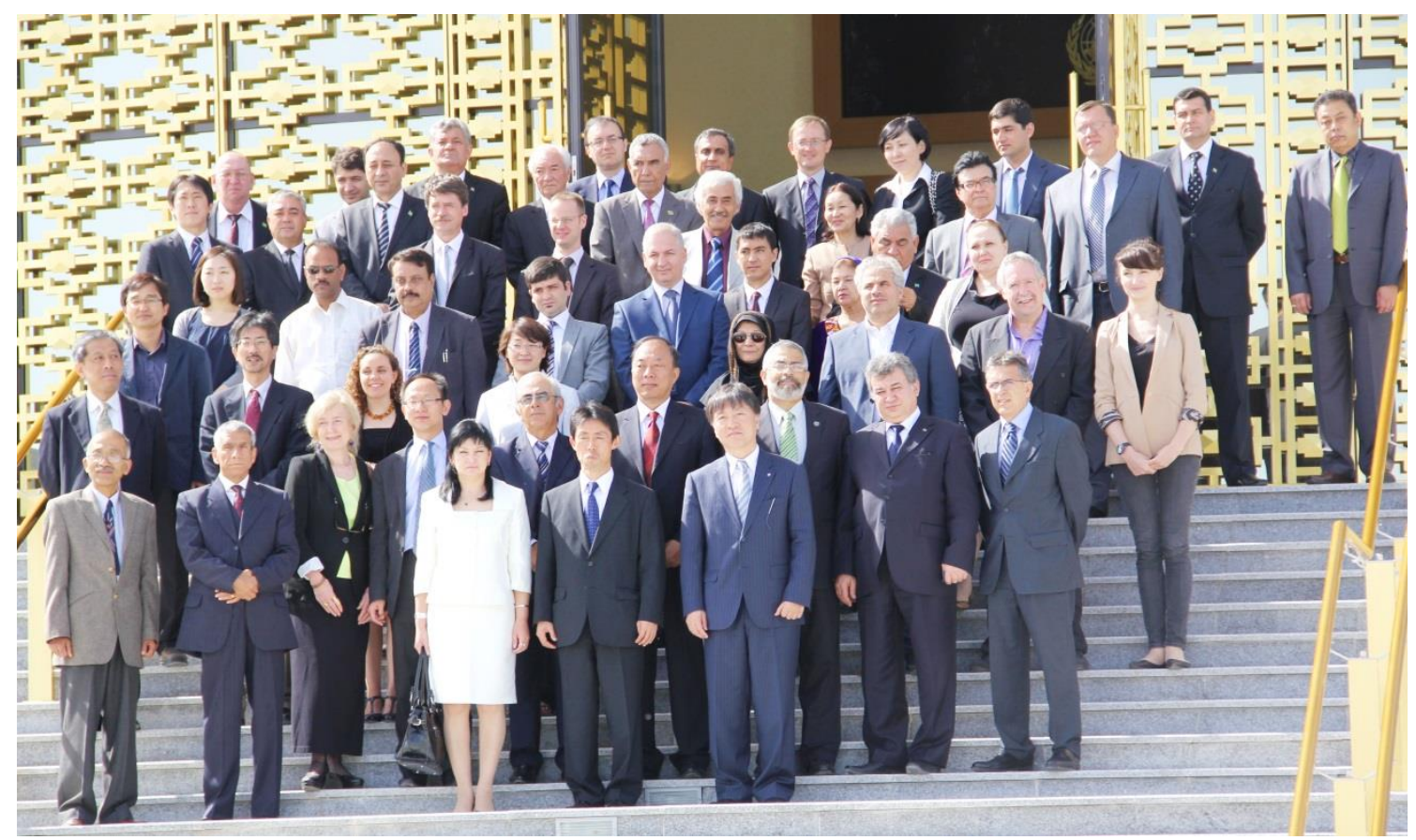

Figure 10. Delegates at the 2011 Ashgabat meeting. 


\section{The UNESCO/Korean Funds-in-Trust "Support for the Preparation for the World Heritage Serial Nomination of the Silk Roads in South Asia Project"}

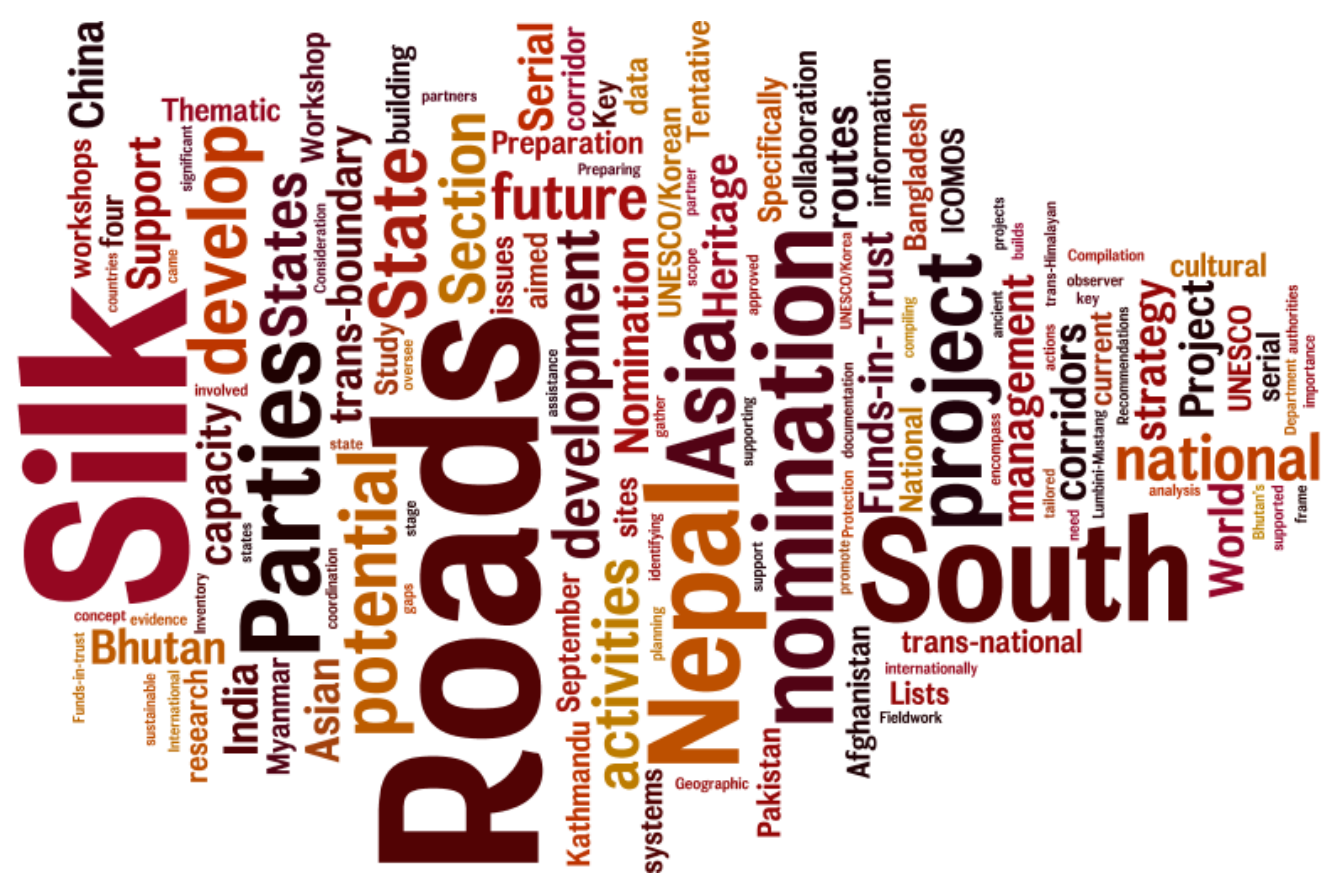

\subsection{Workshop on "Nepal and the Silk Roads", Kathmandu, September 2011}

A National Consultation Workshop on "Nepal and the Silk Roads", supported by the UNESCO/Norway Funds-in-trust within the framework of the Silk Roads Serial World Heritage Nomination Project, was held in Kathmandu, Nepal, on the 6 September 2011. The meeting was organized by the Department of Archaeology (DoA), Nepal and UNESCO.

Key national issues and future actions were discussed. These raised a number of issues that would help to frame the Korea-Funds-in-trust project. Specifically:

a) The need for project manager to oversee the nomination process, with supporting capacity building for compiling nomination dossiers;

b) International collaboration for trans-boundary routes - with consideration of transboundary corridor management systems;

c) Consensus building on potential corridors;

d) Compilation of existing data and additional research to fill gaps;

e) Understanding the surviving physical site evidence and its current condition;

f) Consideration of the types of property for nomination;

g) Preparing Tentative Lists focused upon the specifics of the Silk Roads;

h) Data management - including systematic documentation (the development of national inventories) and the use of geographic information systems;

i) Approaches to comparative analysis;

j) Protection, preservation and conservation - Management planning.

\subsection{Geographic scope \& partners}

The ancient Silk Roads in South Asia encompass the modern-day states of China, Myanmar, 
India, Bangladesh, Bhutan, Nepal, Pakistan and Afghanistan (Figure 1).

China was one of the original UNESCO Silk Roads partner countries, and India and Nepal both recognised, at an early stage, the potential of joining the programme. Bhutan have come on board, as an observer, more recently. To date, these four State Parties have been actively involved in the current South Asian project.

Obviously, it would be useful if Afghanistan, Pakistan, Bangladesh, and Myanmar could become engaged in the project in the future.

\subsection{Aims \& objectives}

The UNESCO/Korean Funds-in-Trust Project, Support for the Preparation for the World Heritage Serial Nomination of the Silk Roads in South Asia, was approved by the Korean donor on 18 July 2013. The project aimed to provide assistance to begin the Silk Roads nomination process in South Asia, by help to develop sustainable capacity, to protect cultural heritage sites, and bring forward future serial trans-national Silk Roads nominations. Specifically, it aimed to:

1) introduce the concept of 'corridors', in line with the ICOMOS Silk Roads Thematic Study (Williams 2014), to the State Parties of Bhutan, China, India, and Nepal, and to take steps towards identifying potential corridors for future serial and transnational nomination projects in South Asia;

2) support the participating States Parties in updating their Tentative Lists to reflect the potential Silk Roads sites in their territory;

3) to develop the State Parties capacities for trans-boundary activities and promote collaboration between the four States Parties;

4) recognising the different state of preparation of the States Parties, and that the platform of information within each State Party varied widely ${ }^{4}$, to further develop institutions within the States Parties to facilitate the coordination of national research, management, and nomination activities between different authorities;

5) develop capacity-building efforts tailored to the necessities of each State Party5;

6) and through these processes, to contribute to the protection of key segments of these internationally significant cultural routes.

\subsection{Key activities}

The main activities that have taken place under the UNESCO/Korea Funds-in-Trust project were:

- Sub-regional and national workshops: to develop approaches, build capacity and foster trans-national working. These are described in Section 1.

- The development of a South Asian nomination strategy: this came from the workshops and meetings summarised in Section 1. The detail of the strategy is presented in Appendix 1. The strategy builds on the initial ICOMOS Silk Roads Thematic Study, which recognised the significance of trans-Himalayan routes and the importance of the connections within and beyond South Asia (Williams 2014).

- The development of Recommendations for the South Asian Silk Roads (Appendix 2) and its concomitant action plan.

- Fieldwork in Nepal to gather data on the potential Lumbini-Mustang corridor (Section 1).

- Support for the development of Bhutan's National Inventory (Section 1).

\footnotetext{
4 As confirmed in the 2013 consultation meetings - see section 1.

5 The 2013 consultation mission to Bhutan (see section 4.3), for example, revealed the need for national inventory development and training as part of Bhutanese capacity building.
} 


\section{South Asian missions, workshops \& activities within the framework of the project}

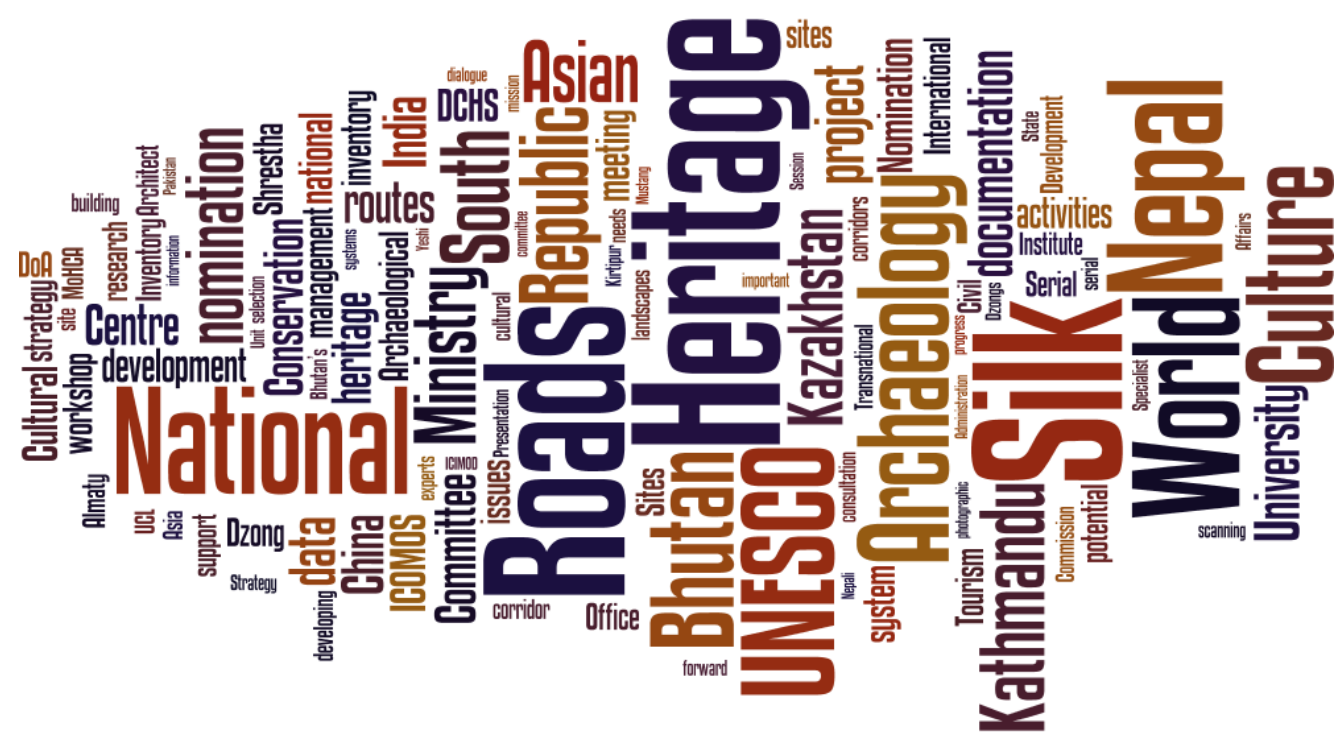

\subsection{Advisory mission to Kathmandu, Nepal: 28 April - 2 May, 2013}

\subsubsection{Background}

Ms Susan Denyer's (ICOMOS) report on the 2011 mission provided essential background to the discussions. Nepal has for many centuries played a pivotal role in trade \& communication between China and India. Trade - in goods such as tea, salt, cloth and precious metals provided the catalyst for long-distance exchange, south to the Gangiatic plain of India and the coastal ports, and north to the Tibetan Plateau and beyond to the routes along the southern margins of the Taklamakan Desert and on to Central Asia or deeper into China. Along these routes the passage of pilgrims, traders and travellers resulted in the flow of ideas and beliefs, technological innovations, artistic and architectural styles, and much more.

\subsubsection{Aims and participants}

The Government of Nepal and UNESCO Kathmandu Office made excellent arrangements for the mission, which took place in Kathmandu between 28th April and 2nd May, 2013. The mission was a follow-up to the recommendations of Advisory Mission by Ms Susan Denyer of ICOMOS (July 2011) and the discussion of national experts at a National Consultation Workshop "Nepal and the Silk Roads", held in Kathmandu on 6th September 2011.

The principal meetings consisted of:

1) Morning 29th April (held in the Department of Archaeology): an introduction to the Department of Archaeology and the mission.

2) All-day 3oth April (held in the Department of Archaeology): discussion of the Silk Roads Serial Nomination process and its implementation in Nepal. The morning comprised presentations on current work and ideas, and the afternoon focused on 
discussions of potential routes, their individual merits, and the ways forward with the trans-boundary project.

Morning 1st May (held at UNESCO Kathmandu Office): to discuss practical ways forward and exchanges of data.

Thanks to the staff of the Department of Archaeology, including the Director General Bhesh Narayan Dahal, Deputy Director General Bharat Mani Subedi, Ms Saubhagya Pradhananga and Mr Ramesh Thapaliya. Also academic advice from national experts Mr Bishnu Raj Karki and Mr Sukra Sagar Shrestha, UNESCO World Heritage Centre Dr Roland Lin, Mr Kai Weise, UNESCO Consultant, and UNESCO Kathmandu, especially Ms Nipuna Shrestha for her work in organising the mission and her excellent contributions to the debate.

\subsubsection{Outcomes}

\subsubsection{Corridors}

Three major corridors of movement were identified in the ICOMOS Thematic Study, in consultation with Nepalese experts. The precise course, components and character of these are currently being explored by the State Party. Three key routes are being considered:

- Eastern route: Patna (Ancient Magadh or Pataliputra) - Vaisali-Simraungarh Sindhuli - Kathmandu -Nesti - Kodari - Xigatse - Lhasa - Tharchindo - Thindafu - ultimately Xi'an

- Central route: Benaras (or Bodhgaya) - Kapilavastu - Lumbini - Butwal - Ridi Kagbeni - Mustang - Lo Manthang - Guge - Puhrang - Leh - Laddakh - ultimately Kashgar

- Western route: Bodhagaya - Surkhet - Jumla - Simikot - Leh - Laddakh ultimately Kashgar

There was considerable debate during the meeting regarding the relative importance and potential of the routes. Reasons were advanced for each, by different specialists. To some extent this reflects the different level of research that have taken place on aspects of each route, and probably also reflects the complexity of changing empire systems and chronologies to the scale of movement long routes (for example, the importance of the Kasa Malla Kingdom in Western Nepal during the $12-14^{\text {th }}$ centuries). In many respects this captures the aims of the Silk Roads Thematic nomination project, which aims to encapsulate the major impacts of the Silk Roads and reflect the different polities and chronologies of this complex network.
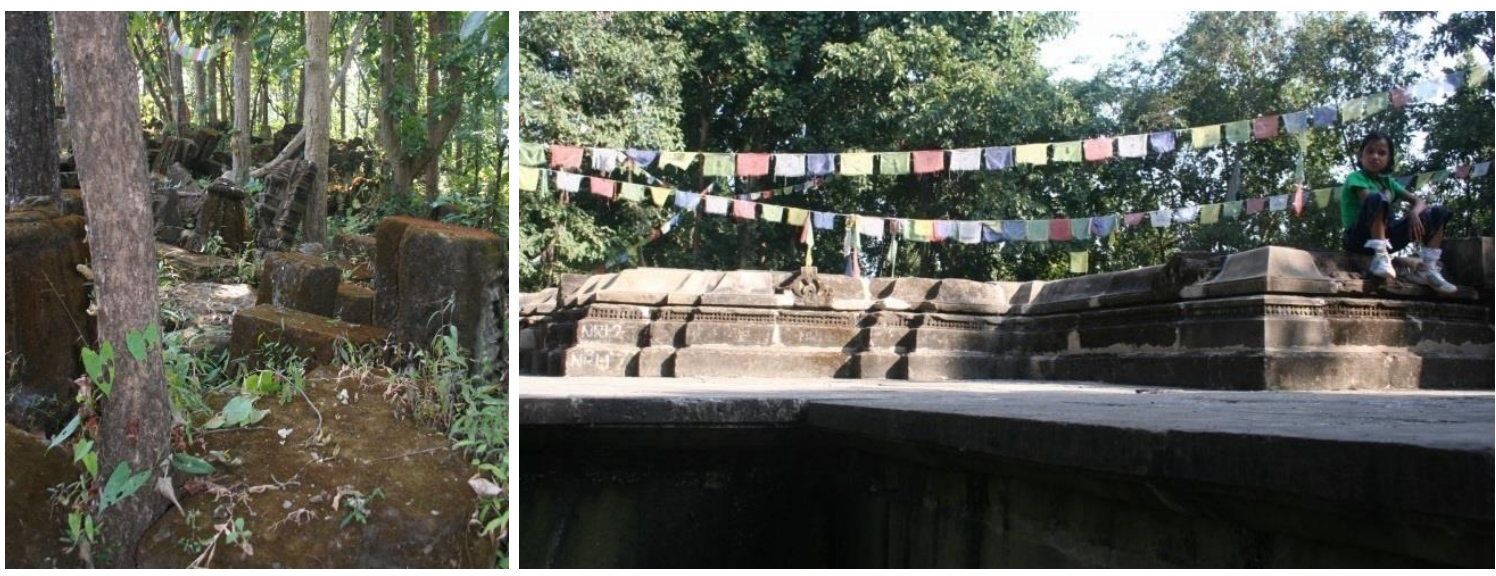

Figure 11. Kakrebihar, near Surkhet, Nepal: $1^{\text {th }}$ century temple complex, demonstrating interplay of Hinduism and Buddhism. 


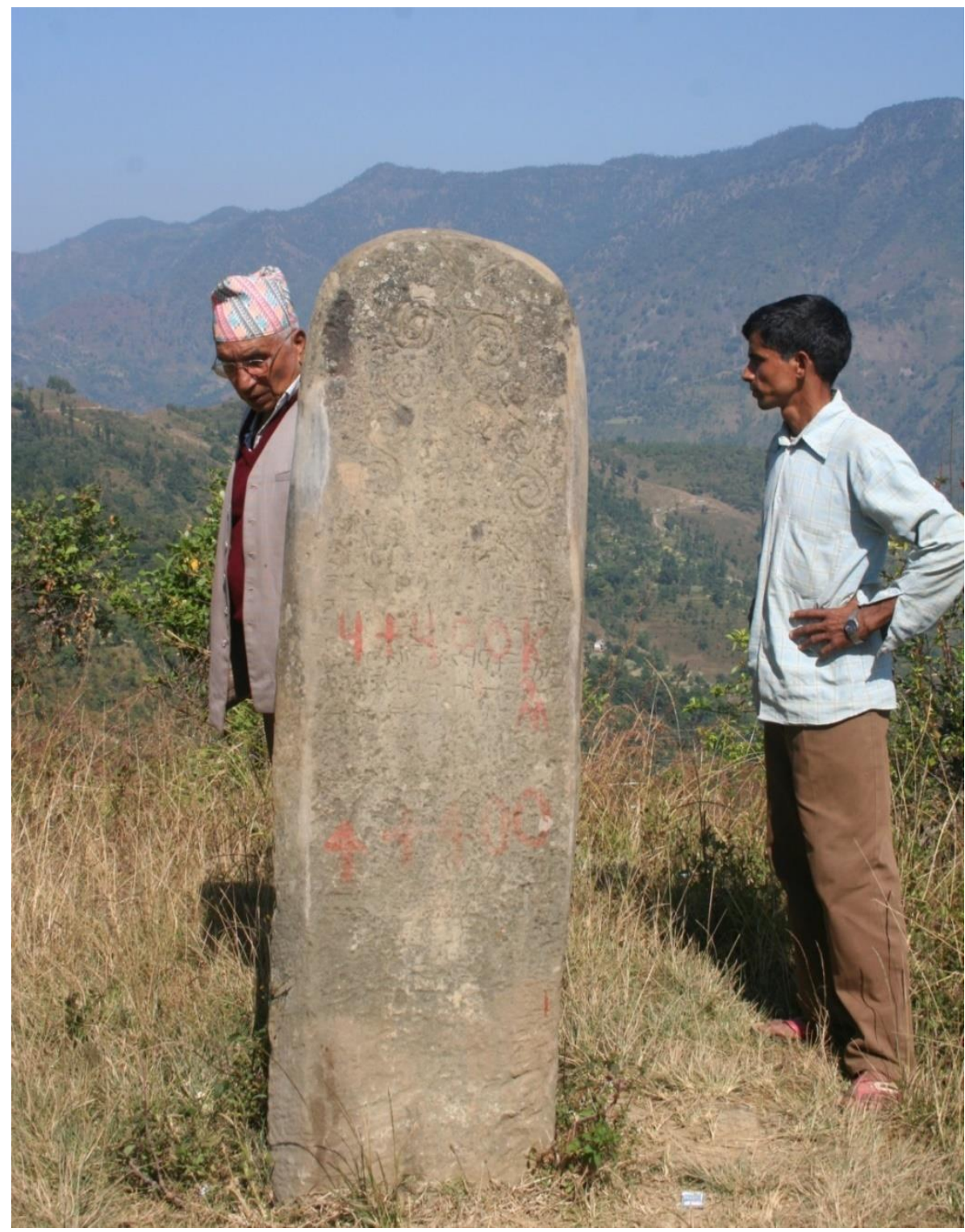

It is also likely that potential transboundary partners, such as China and India, will have views as to the relative importance and priority of the routes. All three routes would be worth pursuing, as they could all make significant contributions to the overall Silk Roads framework. It was suggested that all three merit workingup, with their inventories enhanced, to enable an informed decision about their inclusion and potential components.

It was suggested the information on routes be provided as an addendum to the ICOMOS Thematic Study.

Figure 12. Pillar stone (khambha), marking the route north of the Surkhet Valley, Nepal.

\subsubsection{Focal point in Department of Archaeology}

There is a need to designate a National Project Manager within the DoA, who should have the responsibility to oversee the whole nomination process of Silk Roads in Nepal. This role needs someone who can:
a) Act as a focal point of communication;
b) Coordinate DoA activities and staff;
c) Liaise with external national partners/advisers;
d) Liaise with trans-national partners;
e) Design (in consultation) and manage documentation system;
f) Write substantial parts of the nomination dossier(s), and coordinating the input of all other material to these.

If necessary, priority should be given to capacity building in support of this project manager. There is a need for some stability in this post if at all possible: realistically the nomination process is likely to last a number of years. 


\subsubsection{Inventory and documentation}

It will be necessary to assemble a project team within the DoA to undertake Silk Roads documentation and inventory work. Assistance will be needed to undertake mapping, cataloguing maps, developing inventory, developing systems to manage data, etc. This team could be supported by local students in conservation project practice, especially from Institute of Engineering, Khwopa Engineering College, Kathmandu Engineering College, etc. - and from the Archaeology Department in Thribhuvan University, and the Centre for Nepal and Asian Studies (CNAS). This support should not be considered as a substitute for the DoA project team, but as additional support.

Simple steps might include:

- start working with existing mapping, including researching digital data available for Nepal to find appropriate base maps and imagery ${ }^{6}$;

- $\quad$ adding depth to the inventory: adding basic descriptive material, scanning/collecting representative photographs for the sites, and collating documentation/earlier research and resources available in-house (at DoA) or outside (see below);

- creating a central archive of documentation and its management.

Data collection: the plan would be to start by utilising data already in the procession of the DoA. Drawing together this material and designing an effective and systematic computerised inventory record. This needs to provide key data on sites, monuments, landscapes and other historic environment features, acting as a primary index to the holdings of the DoA (drawn, photographic and written, and sources - whether in conventional formats or digital). At the outset it should not be the objective to digitise current holdings, as this would be a very substantial undertaking: rather this is about understanding the quality and range of existing documentation, and establishing a basic understanding of the range and distribution of sites along the proposed corridors. This stage would also serve as a pilot to develop the form of the inventory and will necessarily build on existing systems of documentation, both in the DoA and elsewhere.

The inventory needs to provide sufficient information to reflect the ways a section of the Silk Roads was used over time, and the way its use impacted upon the landscape. This should enable an expression of the distinctiveness of the corridor and why it might be considered for nomination as part of a serial site.

GIS development: There is a need for basic mapping tools, supporting modern and historic mapping (both vector and raster data), satellite imagery and topographic terrain models, combined with details of site locations, extents and boundaries. This should be used to create framework for data management, including the definition of routes and corridor extents.

The DoA should research local data sources for base maps, terrain models, imagery, etc., through official governmental channels. It will be important to ascertain what data is freely available and those elements that need to be purchased. It may not be feasible to acquire the latter for all the corridors: purchase might be best focused on selected sites/landscapes based on specific needs, but until the costs have been established this is impossible to predict. It would also be important to ensure as much compatibility with other government agencies.

Capacity building: is clearly essential in the area of inventories and geospatial data. The most sustainable process would involve the provision of local training from agencies in Nepal. Commercial training is thought to be prohibitively expensive, but it is possible that other agencies, governmental or NGO, might be able to provide local support and advice.

Online data exchange: it will be important to develop systems which enable transnational working with potential partners in any Silk Roads nomination project.

6 Via Department of Survey (http://www.ngiip.gov.np/), ICIMOD (www.icimod.org), satellite images, etc. 
Data sources: collating data from other sources. To draw from the various research projects that have taken place in Nepal, including:

- $\quad$ Prof Sudarshan Taj Tiwari's research at Lo Manthang;

- $\quad$ Ms Maïe Kitamura's research at Lo Manthang;

- $\quad$ Prof Susanne von der Heide work in Mustang;

- $\quad$ Tim and Chiz Harward's work in Surkhet and Dailekh, west-central Nepal;

- Thribhuvan University.

\subsubsection{Further field research}

There are likely to be a number of areas where information site survival, character, location and current condition are not sufficient to support corridor prioritisation or site selection. Realistically, improving the depth and quality of the national inventory is a very long-term mission. For the purposes of the Silk Roads nomination project there will need to be a very clear strategy for additional fieldwork, focused on areas where the DoA feel that the knowledge of sites/landscapes is currently too poor to make judgements. Selection of sites/landscapes for fieldwork will also take into account those areas where Archaeological Impact Assessments are needed in advance of potential development threats, including the current programme of road construction.

A priority for any fieldwork, given the logistical issues of visiting many of the areas along the corridors, should be to gather sufficient data to support the nomination dossier (should the site be selected), supported by basic inventory data. This should include information on current condition, issues and threats, potential boundaries and buffer zones, etc.

\subsubsection{New Silk Roads tentative list}

The updated inventory (above) will form the basis for a new Nepalese Tentative List for the Silk Roads. It should contain reasonably detailed site/landscape descriptions, site coordinates and date ranges, in order to enable the characterization of the site geographically (by type) and culturally and historically (by period); the whole should be accompanied by a detailed map of the Silk Roads in Nepal. This should include:

- $\quad$ Geographical parameters (assessment of the spread and extent of the corridor in spatial terms) including coordinates of sites;

- Short discussion of geopolitical regions, site-type variability, chronological variations.

It would be appropriate to wait until after discussion with transnational partners before creating this new Tentative List. Dialogue with partners will undoubtedly refine and shape the OUV of the transnational corridor, and thus shape the selection of sites and landscapes within the corridor for inclusion.

\subsubsection{Management planning}

Key issues that need to be developed include:

- Local and traditional approaches, with sustainable local partnerships and clear lines of appropriate decision-making;

- Consideration of sustainable tourism management strategies, appropriate to the different sectors of the corridors.

\subsection{Consultation meetings in Nepal: 27 October -3 November 2013}

Prof Roland Lin of the UNESCO World Heritage Centre participated in and facilitated a number of consultation meetings with the UNESCO Field Office in Kathmandu, the Ministry of Culture, Tourism, and Civil Aviation of Nepal, the Department of Archaeology (DoA) of Nepal, and other related Nepali authorities and experts, for the planning and execution of the Korean FIT activities both nationally in Nepal and sub-regionally within South Asia. WHC 
staff briefed Nepali authorities and experts on the scope of the Korean FIT project and its activities, to facilitate discussion of their implementation within Nepal, and within the larger scope of the project.

UNESCO staff also discussed the necessity for a Silk Roads World Heritage nomination strategy to be developed, with assistance and advice of an outside expert, with Nepali authorities. Discussions also took regarding Nepal hosting a sub-regional Silk Roads consultation meeting in Kathmandu, to be joined by representatives and experts from Bhutan, China, India, and Nepal, which was proposed for April 2014.

UNESCO staff also reviewed ongoing research with Nepali authorities and experts, including three proposed Silk Roads heritage corridors within Nepal. As a result of these consultation meetings, the creation of an inter-departmental Silk Roads national coordinating committee in Nepal was proposed, to be tasked with organising follow-up activities and ensuring the further development of inventory and documentation research and nomination capacitybuilding.

\subsection{Thimphu, Bhutan: 24 November - 1 December 2013}

\subsubsection{Aims}

This mission aimed to facilitate discussions with the Bhutanese heritage agencies regarding their potential involvement in the South Asian Silk Roads trans-boundary nomination project. The objective was to explain the existing UNESCO Silk Roads strategy and to discuss Bhutan's potential participation in trans-boundary activities with Nepal, China and India.

The mission collated information and opinions on possible corridors, and specific sites and landscapes, within Bhutan. It also discussed practical issues with Bhutan's engagement with the process, including current capacity and the opportunities for future capacity building.

In addition, the mission aimed to establish direct contacts between interested parties in Bhutan and the UNESCO South Asian Silk Roads strategy to improve the dialogue in the strategy development phase.

\subsubsection{Workshop on Serial Nomination of Silk Roads in South Asia}

The workshop was held at the National Library Conference Hall in Thimphu on November 28, 2013.

\subsubsection{Aims}

The workshop was focused on developing dialogue regarding Bhutan's engagement with the Silk Roads project. It sought to:

- Provide background to the Silk Roads nomination project;

- Explain the current heritage corridor strategy;

- Discuss Bhutan's World Heritage tentative list;

- Discuss Bhutan's Draft Heritage Sites Bill.

\subsubsection{Participants}

- Mr. Dorjee Tshering, Director General, Department of Culture, MoHCA

- Prof Roland Chih-Hung Lin, Programme Specialist, Asia \& Pacific Unit, World 
Heritage Centre, UNESCO

- Mr. Tim Williams, Senior Lecturer, Institute of Archaeology, University College London (UCL)

- Mr. Harka Gurung, Director, National Library \& Archives, Department of Culture, MoHCA

- Mr. Dorji Wangchuk, Programme Director, Department of Culture, MoHCA

- Mr. Kunzang Delek, Head, Archives Division, National Library \& Archives, Department of Culture, MoHCA

- Mr. Sonam Wangchuk, Chief, Wildlife Conservation Division, Ministry of Agriculture \& Forest

- Ms. Thinley Choden, Wildlife Conservation Division, Ministry of Agriculture \& Forest

- Ms. Dechen Lham, Wildlife Conservation Division, Ministry of Agriculture \& Forest

- Ms. Paimma, National Commission of UNESCO, Thimphu

- Mr. Phenden Wangchuk, Nature Recreation and Park Development Division, Ministry of Agriculture \& Forest

- Mr. Sonam Tobgay, Research and ICT Officer, National Library \& Archives, Department of Culture, MoHCA

- Ms. Kasumi Ishida, Architect, Division for Conservation of Heritage Sites (DCHS), Department of Culture, MoHCA

- Ms. Junko Mukai, DCHS, Department of Culture, MoHCA

- Mr. Karma Tenzin, Architect, DCHS, Department of Culture, MoHCA

- Mr. Sangay Kinga, Asst. Architect, DCHS, Department of Culture, MoHCA

- Mr. Nidup Tshering, Electrical Engineer, DCHS, Department of Culture, MoHCA

- Mr. Choening Dorji, Sr. Architect, DCHS, Department of Culture, MoHCA

- Mr. Yeshi Samdrup, Architect, DCHS, Department of Culture, MoHCA

\subsubsection{Outcomes}

- Roland Lin presented a background on the World Heritage Convention, its implementation, and the development of the Silk Roads serial trans-national project.

- Tim Williams presented the ICOMOS Silk Roads Thematic Study and the Silk Roads nomination strategy. This also explored the extent to which routes through Bhutan could currently be identified. This recognised the limitations of current archaeological knowledge, but also recognised the continuity of settlement landscapes and the constricting nature of topography, identifying a continuity of routes through valleys and mountain passes (Figure 13). It also emphasised the importance of developing a solid data platform for decision-making: building on existing knowledge and documentation to compile a national inventory; using this to target fieldwork; ultimately leading to the selection of a range of sites/landscapes reflecting OUV. It also highlighted the need to develop regional frameworks, at the outset to encompass India, China, Nepal and Bhutan.

- DCHS staff presented Bhutan's World Heritage tentative list, and in particular the possible serial nomination of a selection of Dzongs. The resultant discussion examined how the Silk Roads serial nomination project might act as a basis for capacity building for this form of nomination project. This led to an agreement that it might be useful for Bhutan to join the Silk Roads project, as an observer, to benefit from the strategy discussions and practical implementation issues.

- DCHS staff presented on Bhutan's Draft Heritage Sites Bill and how this might impact upon future heritage site protection and management in Bhutan. The Bill seeks to conserve and enhance the cultural uniqueness and diversity of Bhutan for present and future generations. Specifically, it planned to promote the sustainability of the cultural landscapes and to identify and protect (specific) heritage sites. This initiative was strongly supported in the discussions. 


\subsubsection{Field visits}

A number of field visits were arranged to enable the international partners to see the practicalities of site management and conservation on the ground, and discuss these issues with the DCHS staff. The main visits were to Punakha, via the Dochu La pass (Figure 13), to Tango Monastery, in the Thimphu Valley, and to the ruined Drukgyel Dzong, near Paro.

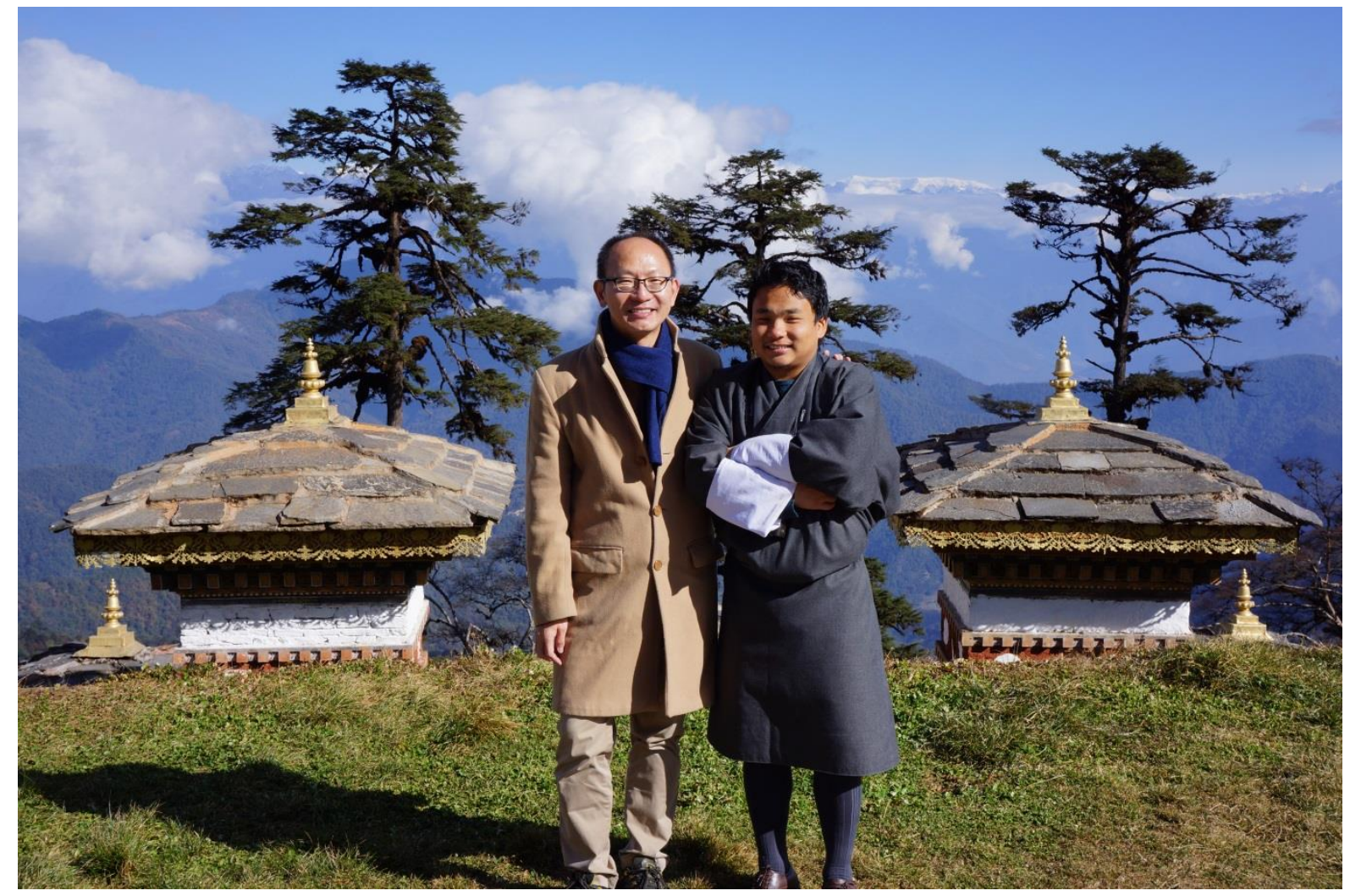

Figure 13. Prof Roland Lin (UNESCO) and Yeshi Samdrup (DCHS) at Dochu La pass (3,116 m) during field visit.

The visit to Punakha Dzong (Figure 14 to Figure 17) enabled discussion of the 'living use' of Dzongs and the complexity and strengths that brings to site management. It raised a number of issues regarding authenticity, the quality of craftsmanship, and the integration of tangible and intangible heritage - all of which will be key issues if Bhutan is to put forward a serial World Heritage nomination of Dzongs. 


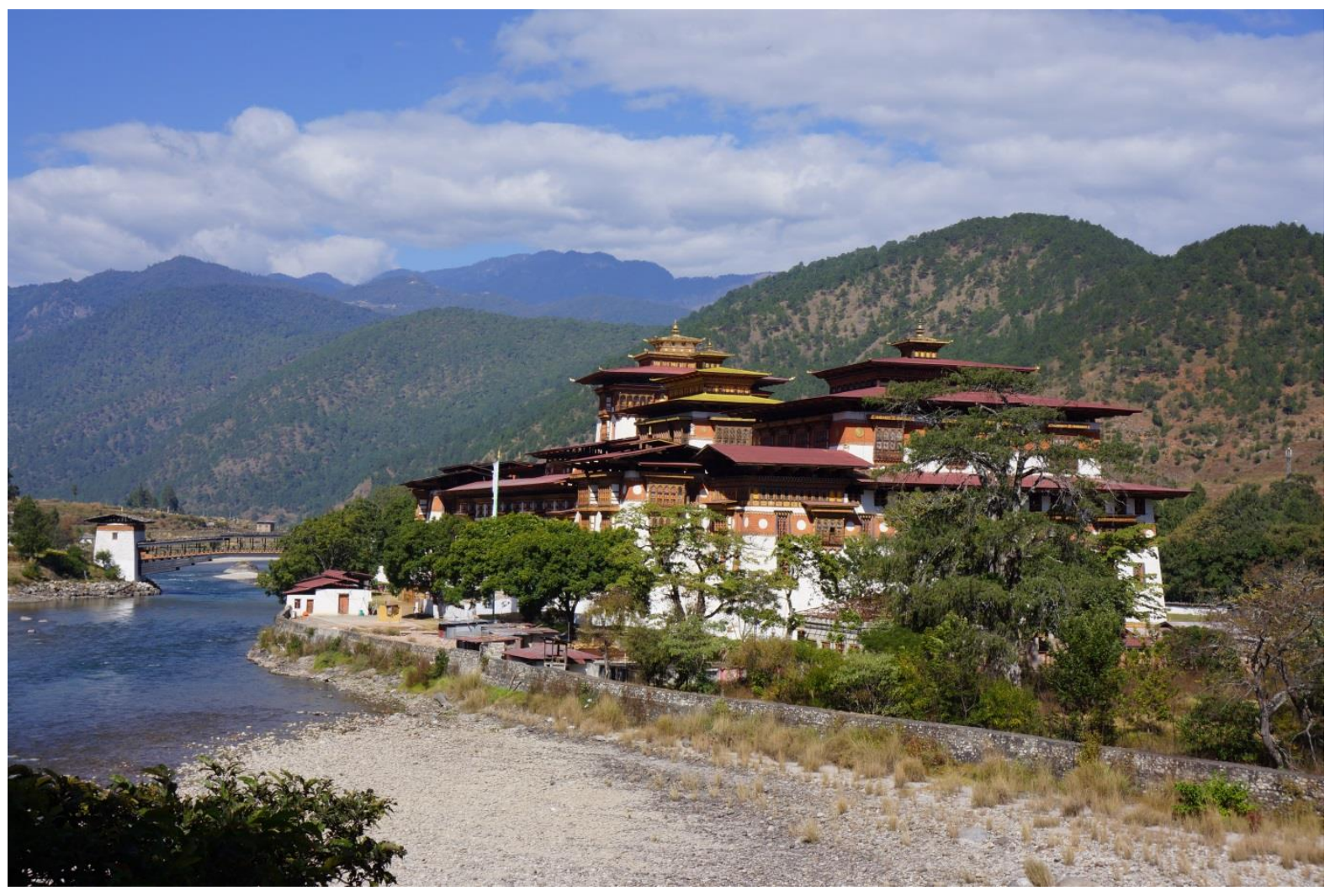

Figure 14. Punakha Dzong.
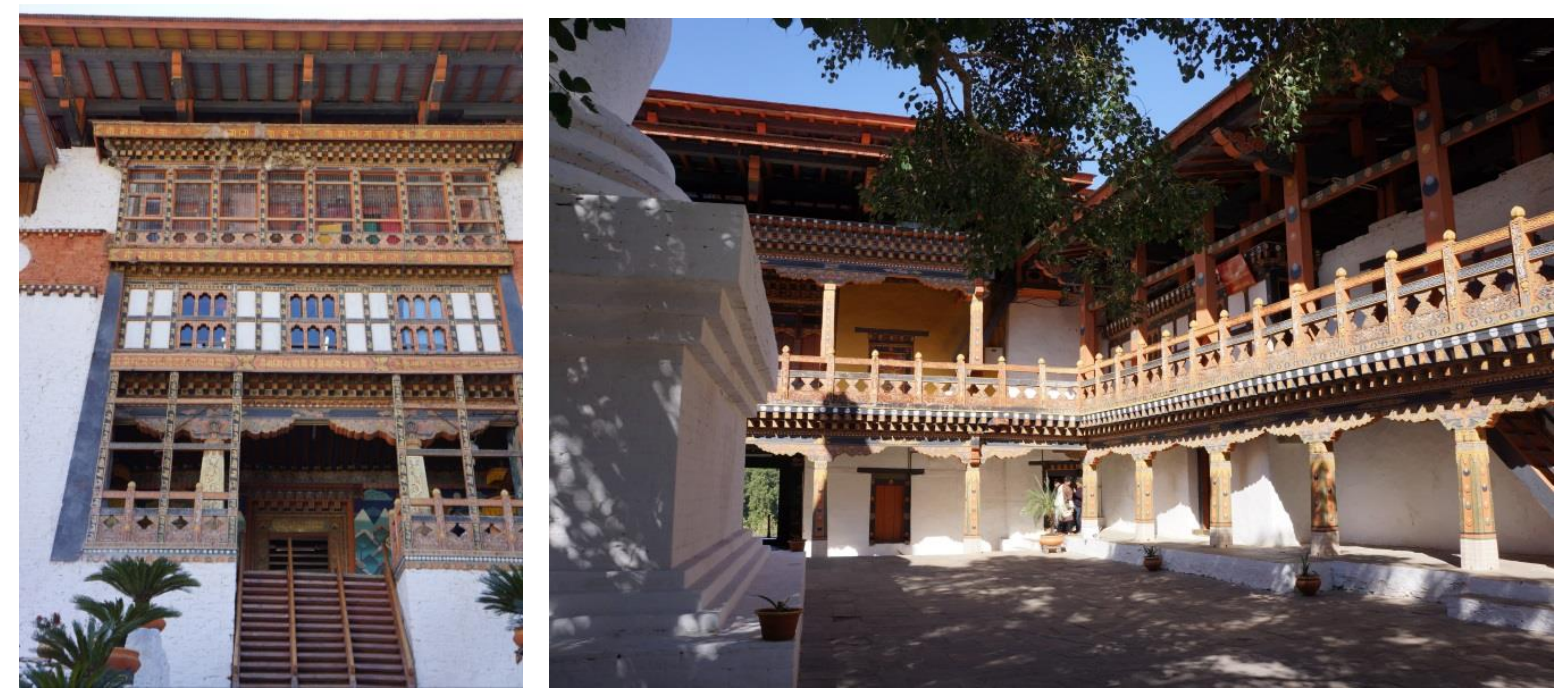

Figure 15. Entrance to Punakha Dzong (left) and inner courtyard (right). 


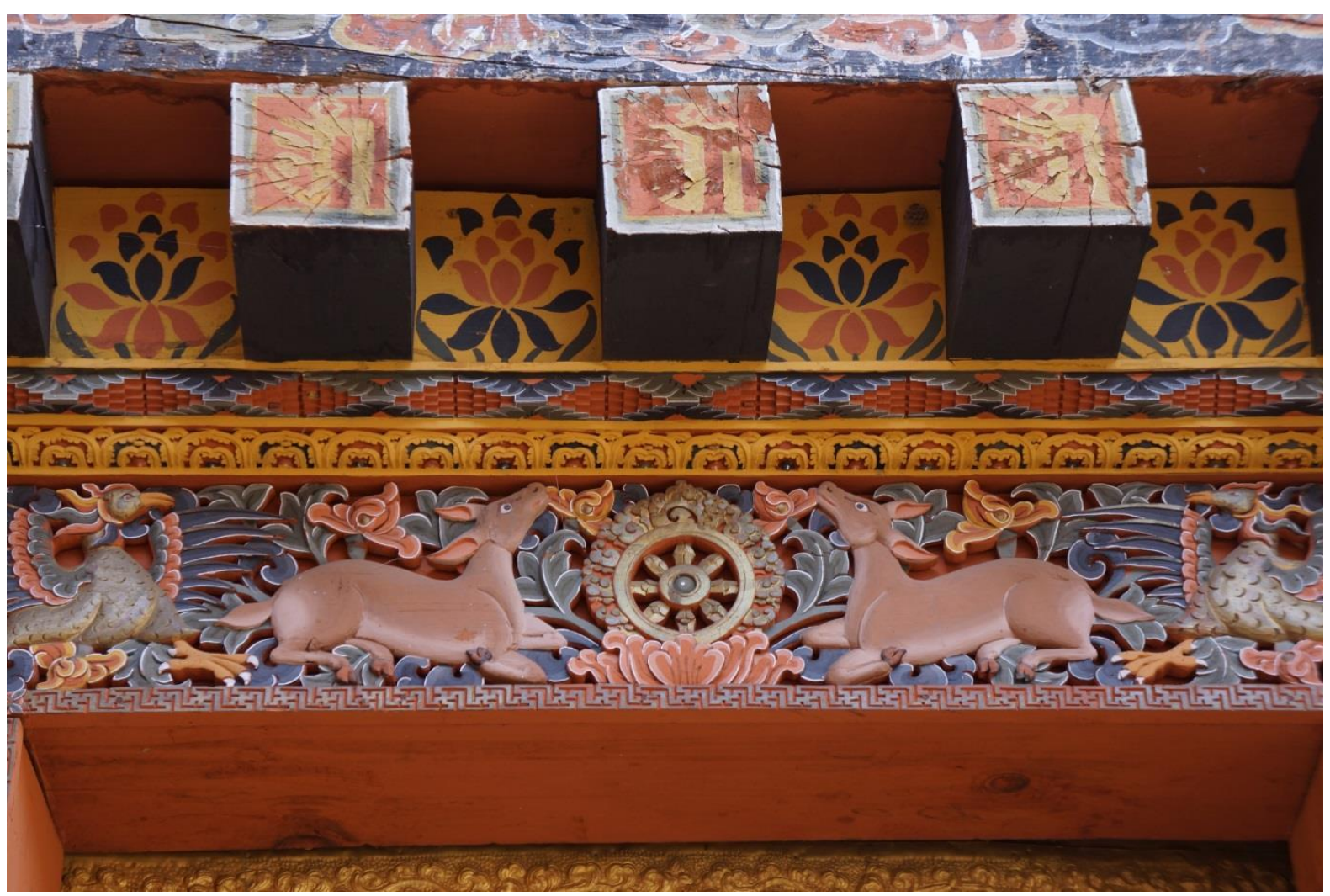

Figure 16. Complex carved and painted woodwork. Conserving this represents a major challenge in terms of maintaining traditional craft skills in timber preparation, carving and painting.
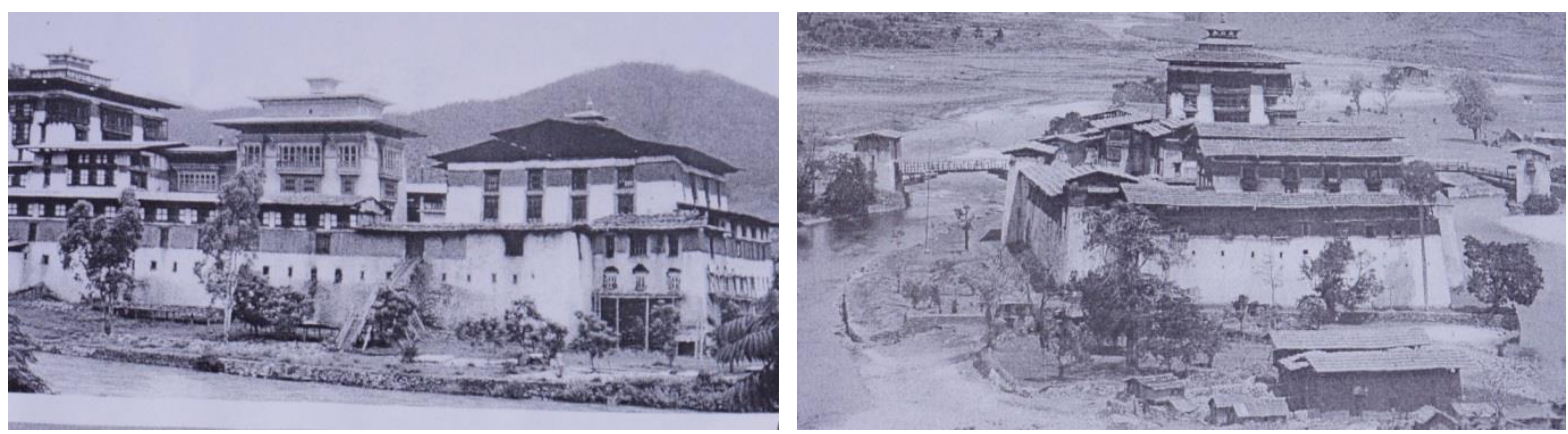

Figure 17. Historic images of Punakha Dzong, useful for assessing early modern modifications to the structure.

A visit to Tango Monastery (Figure 18 \& Figure 19), founded in the $13^{\text {th }}$ century, provided an excellent opportunity to examine issues of sustaining and managing a living monastic community and its built space, alongside the management of tourism. It again raised issues of the repainting of murals to sustain the practice of the monastery. 


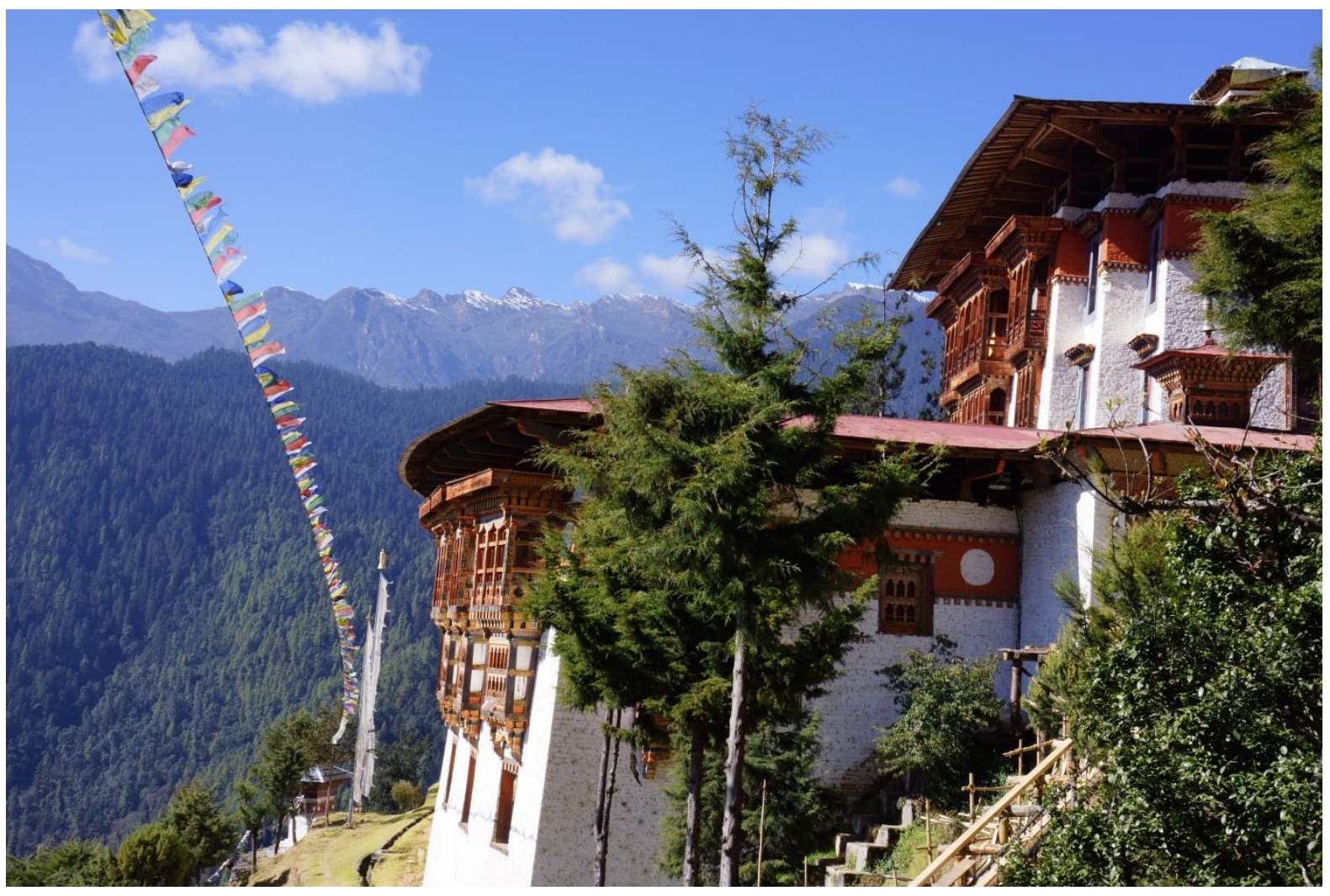

Figure 18. Tango Monastery, with a dramatic hillside setting.
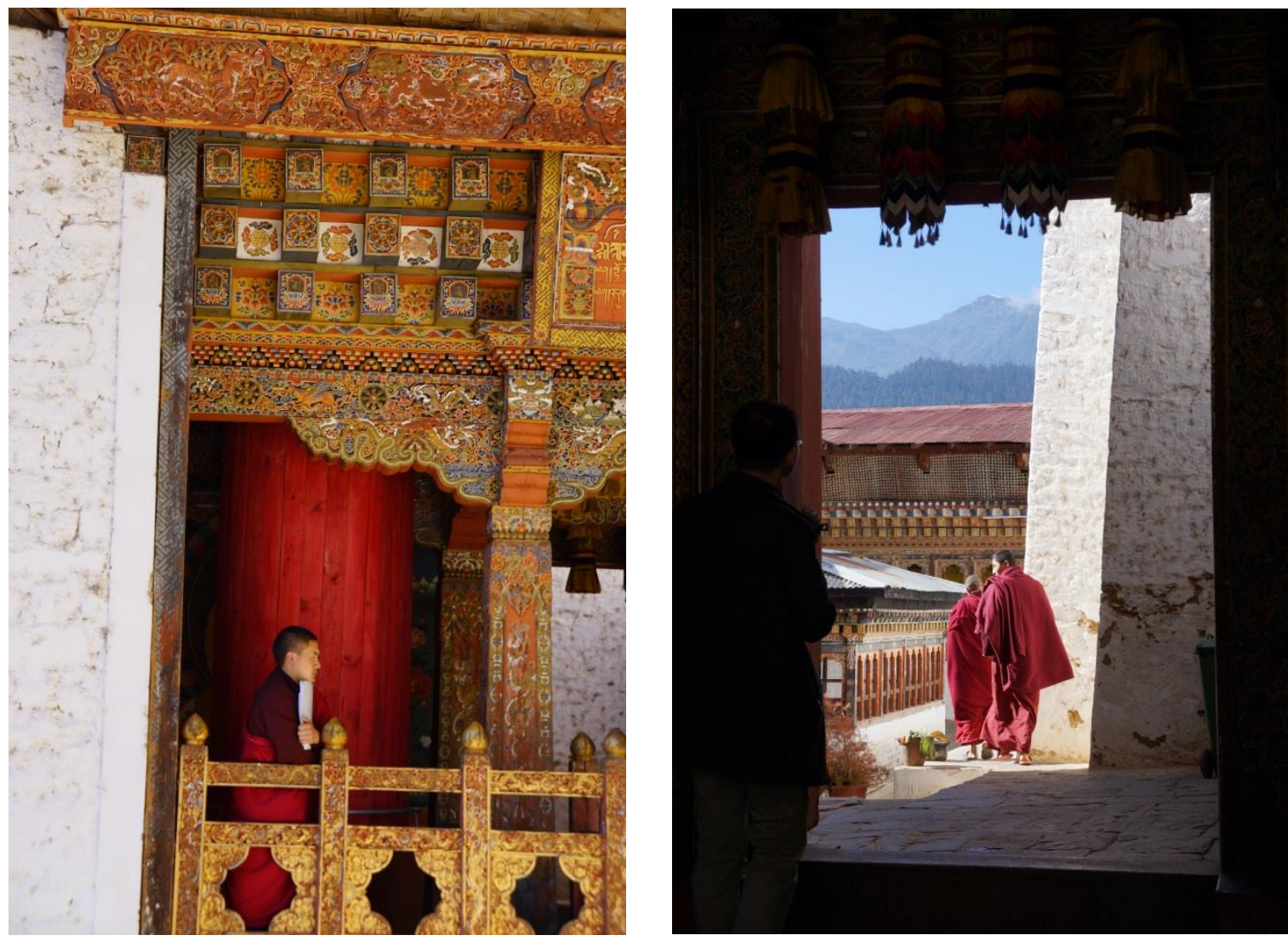


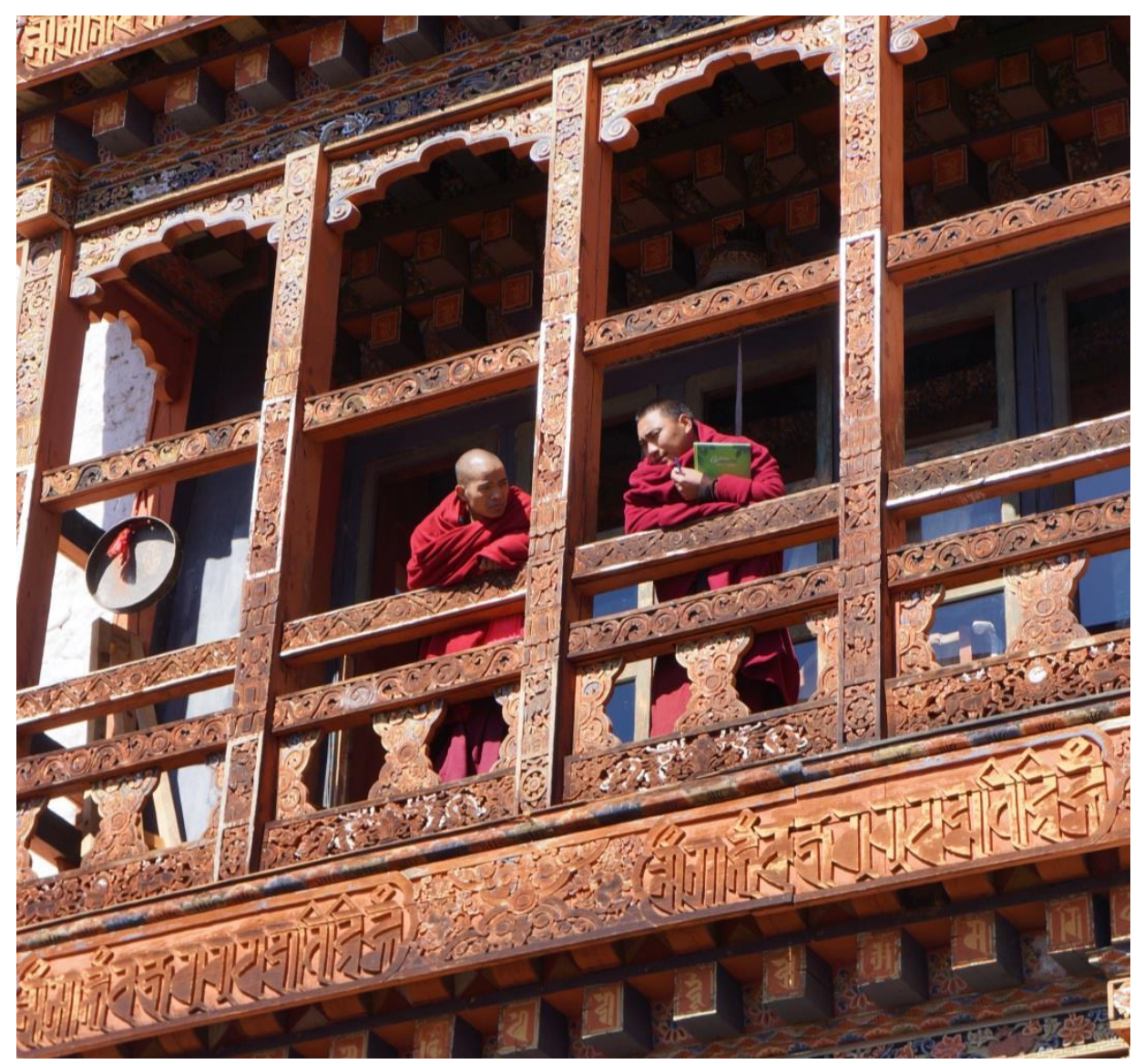

Figure 19. Tango Monastery with an active monastic community.

A visit to Simtokha Dzong (Figure 20 \& Figure 21) highlighted issues of the quality of crafts skills and the need to preserve these to support restoration and conservation programmes.

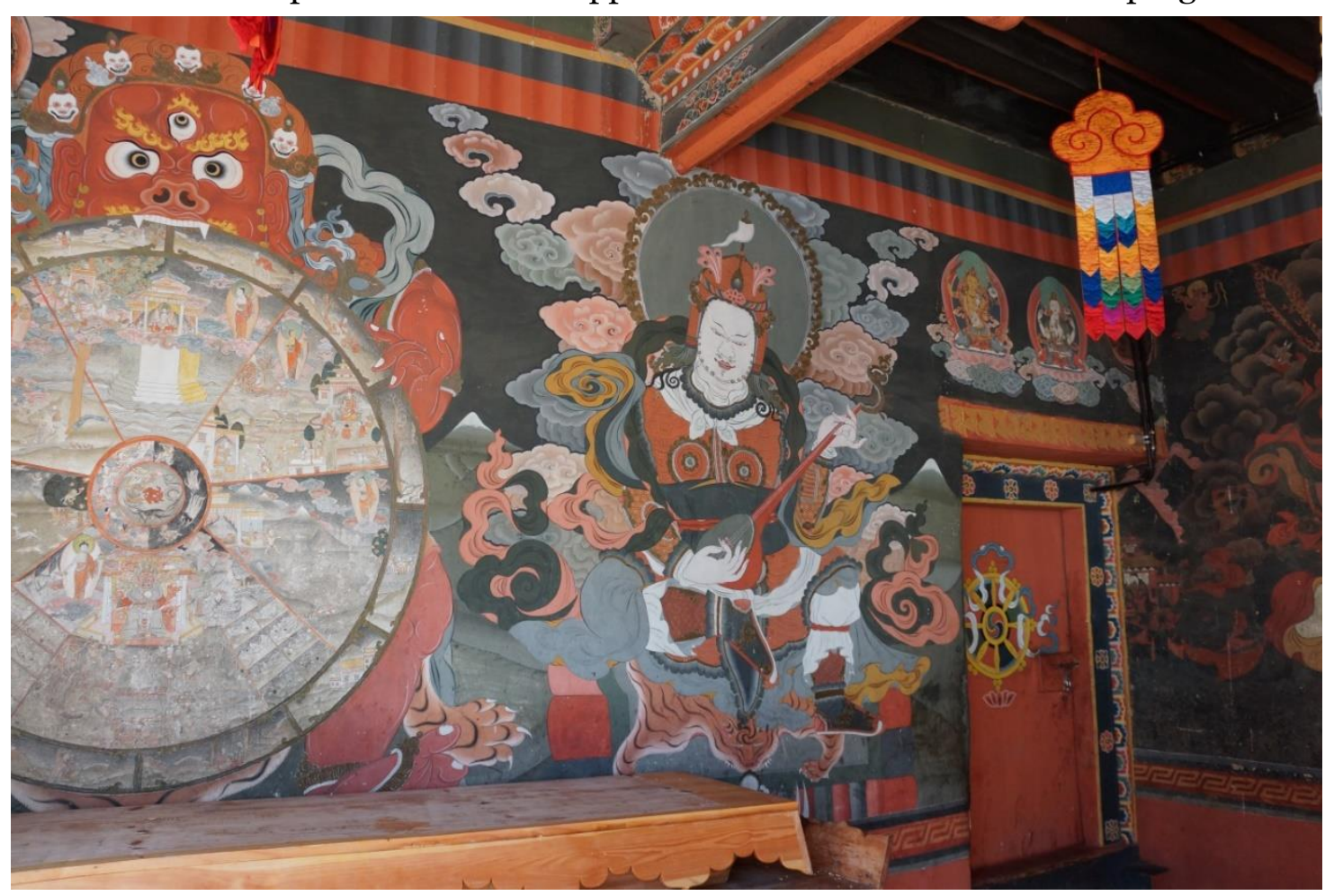

Figure 2o. Simtokha Dzong: complex murals repainted to sustain their role for a living monastic community. 


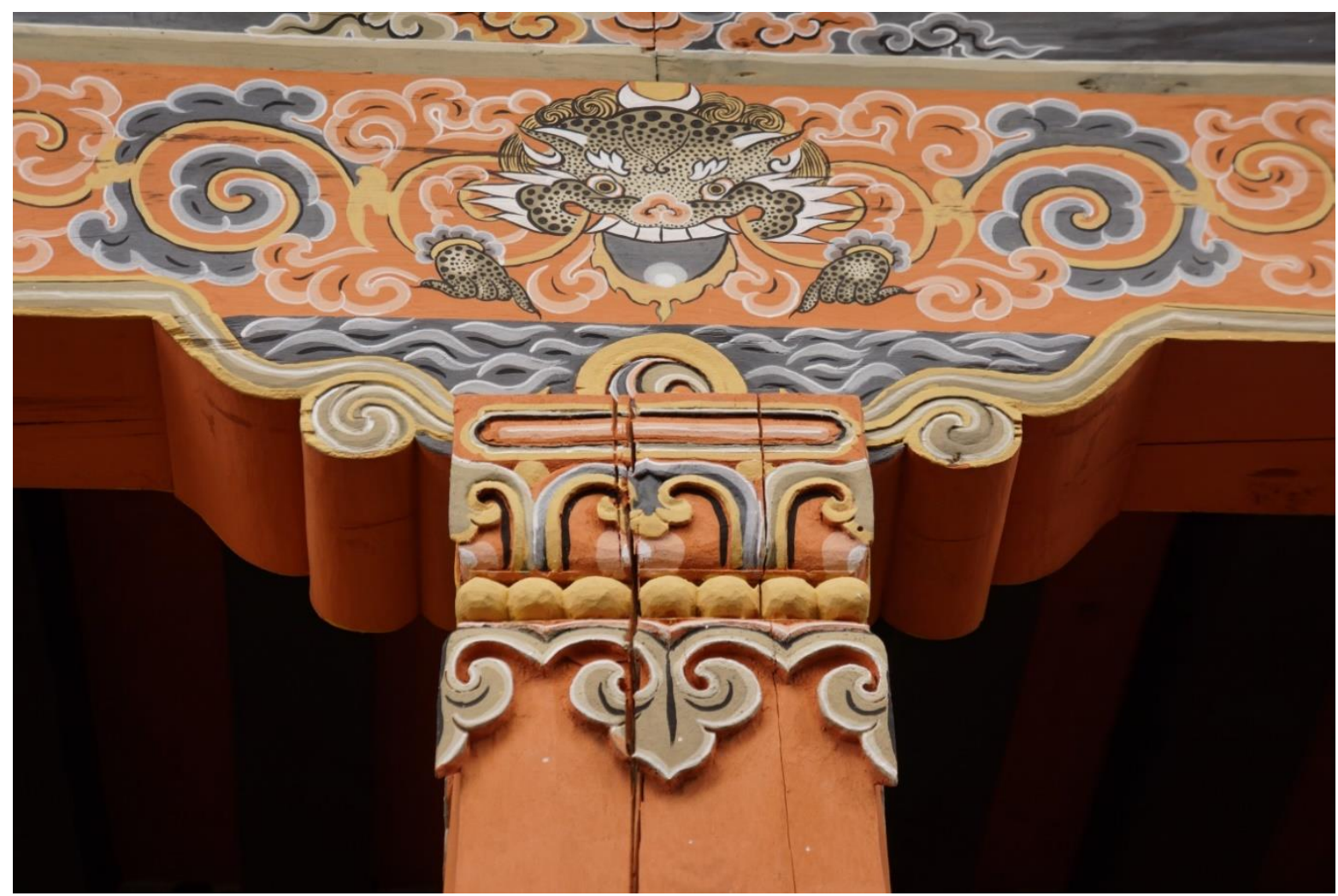

Figure 21. Simtokha Dzong: the replacement of timbers, with some issues of timber preparation, and highlighting the need to maintain wood carving and painting skills.

The visit to Drukgyel Dzong (Figure 22 to Figure 26) provided an opportunity to discuss the management, protection and interpretation of a ruined site, its role in sustainable tourism and the possible role of archaeological excavation in supporting the understanding and management of the monument.

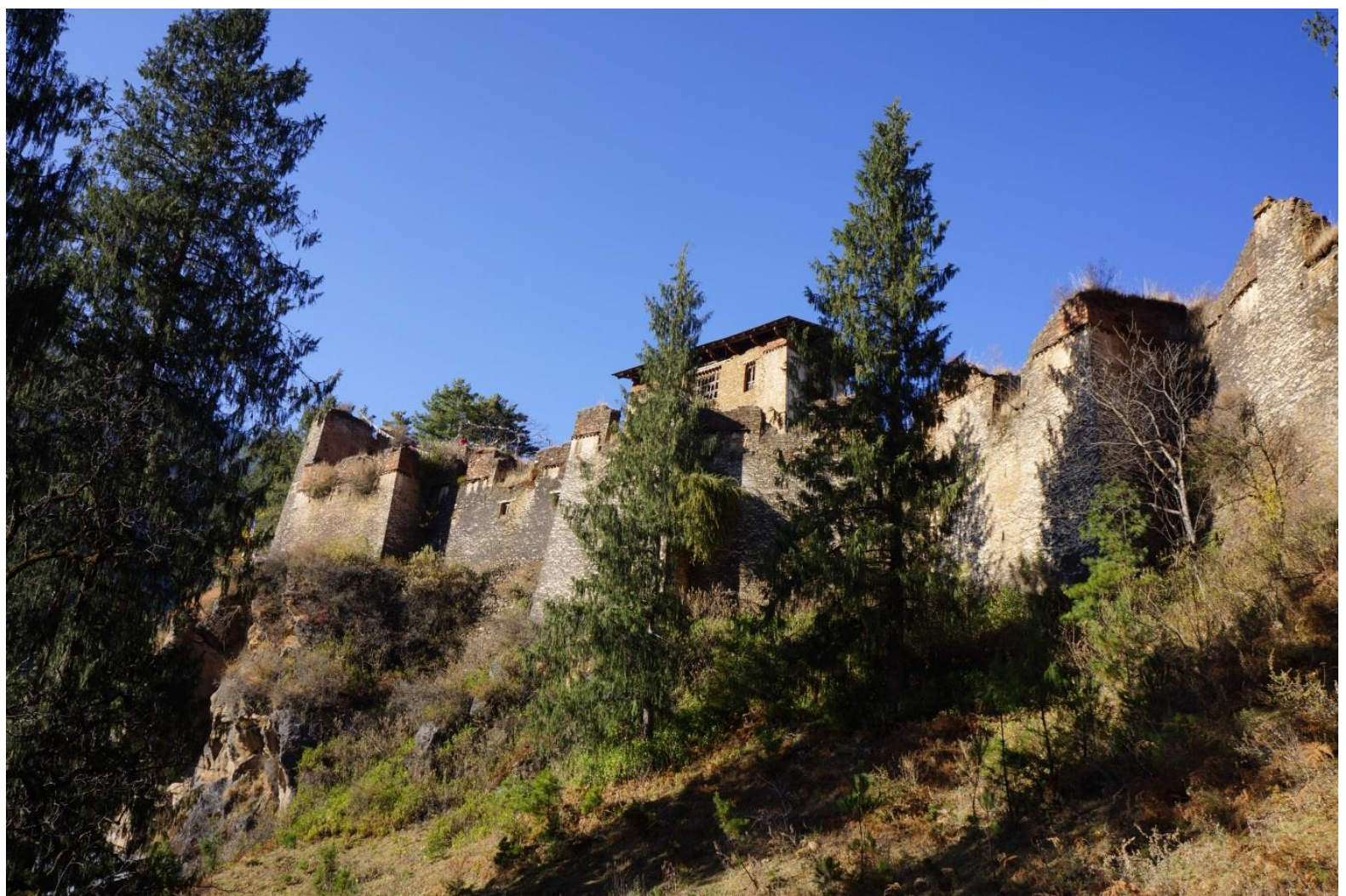

Figure 22. Drukgyel Dzong. 

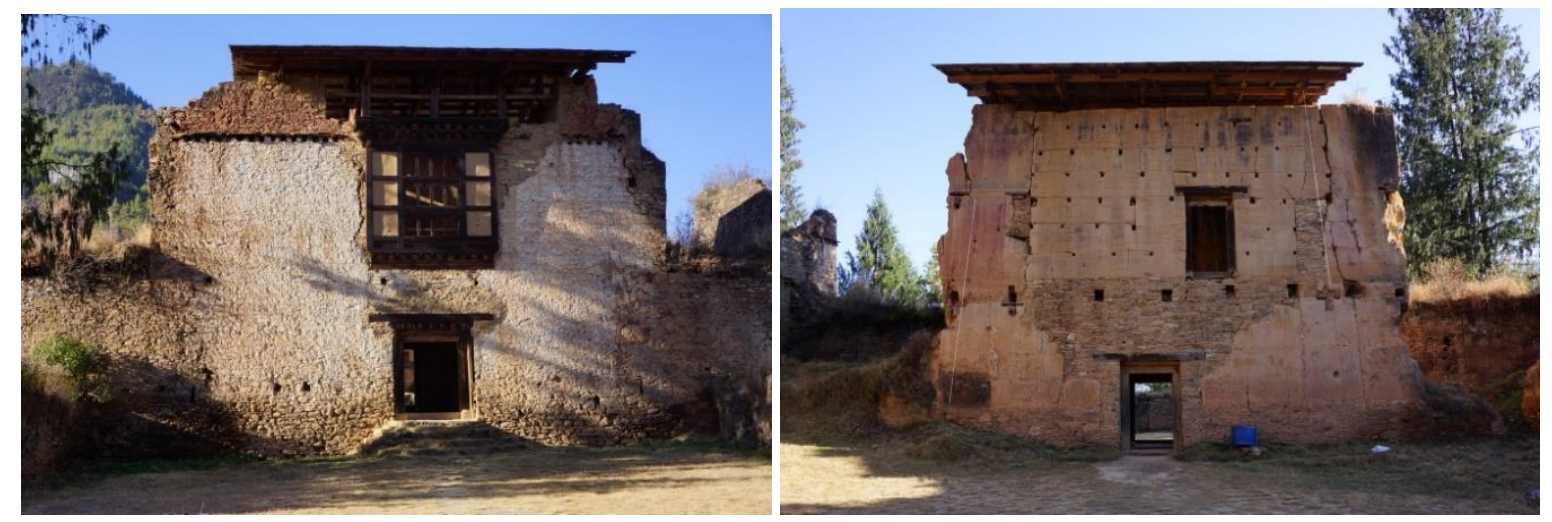

Figure 23. Outer gatehouse: exterior (left) and interior (right), with temporary roof.

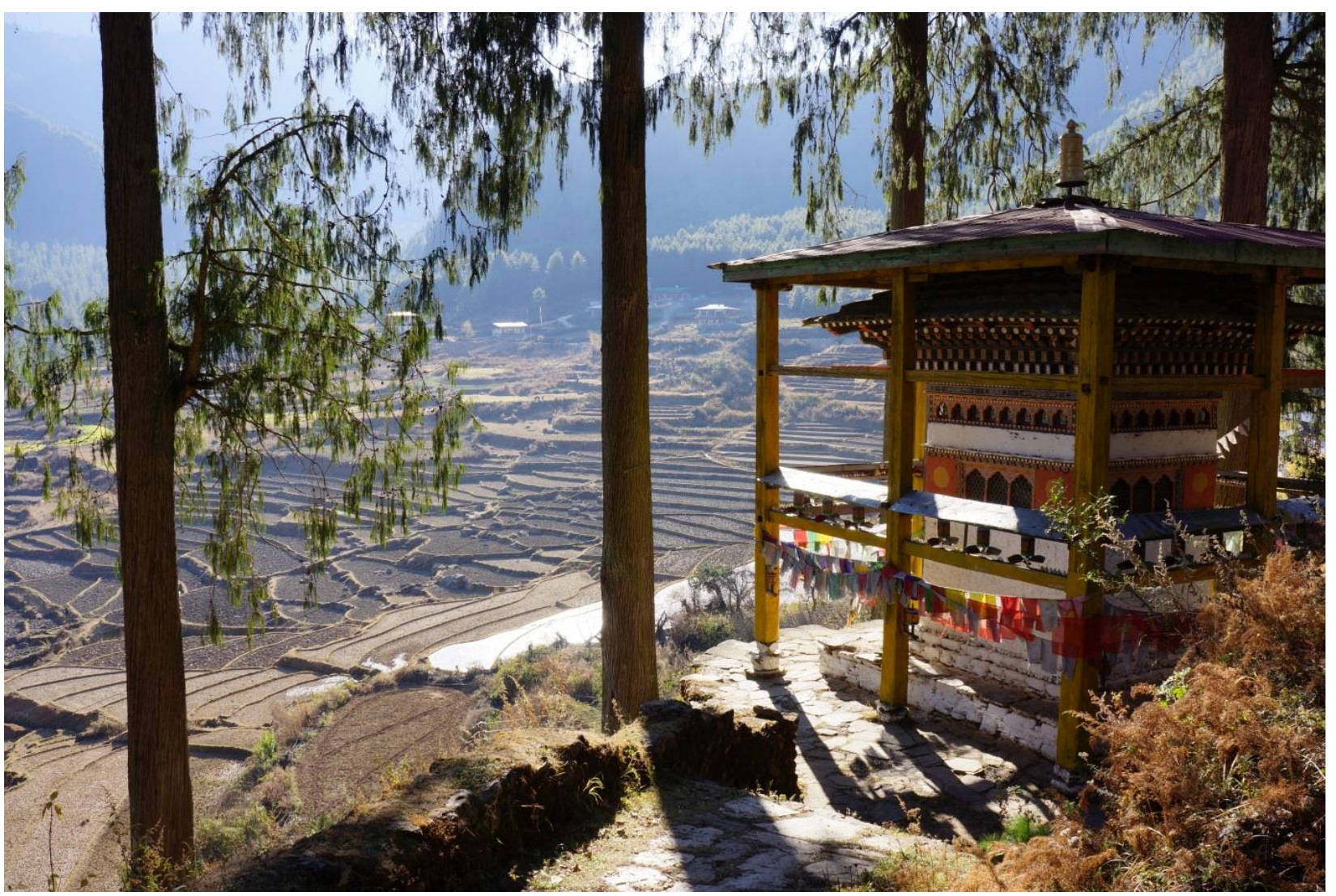

Figure 24. The landscape context of the Dzong 


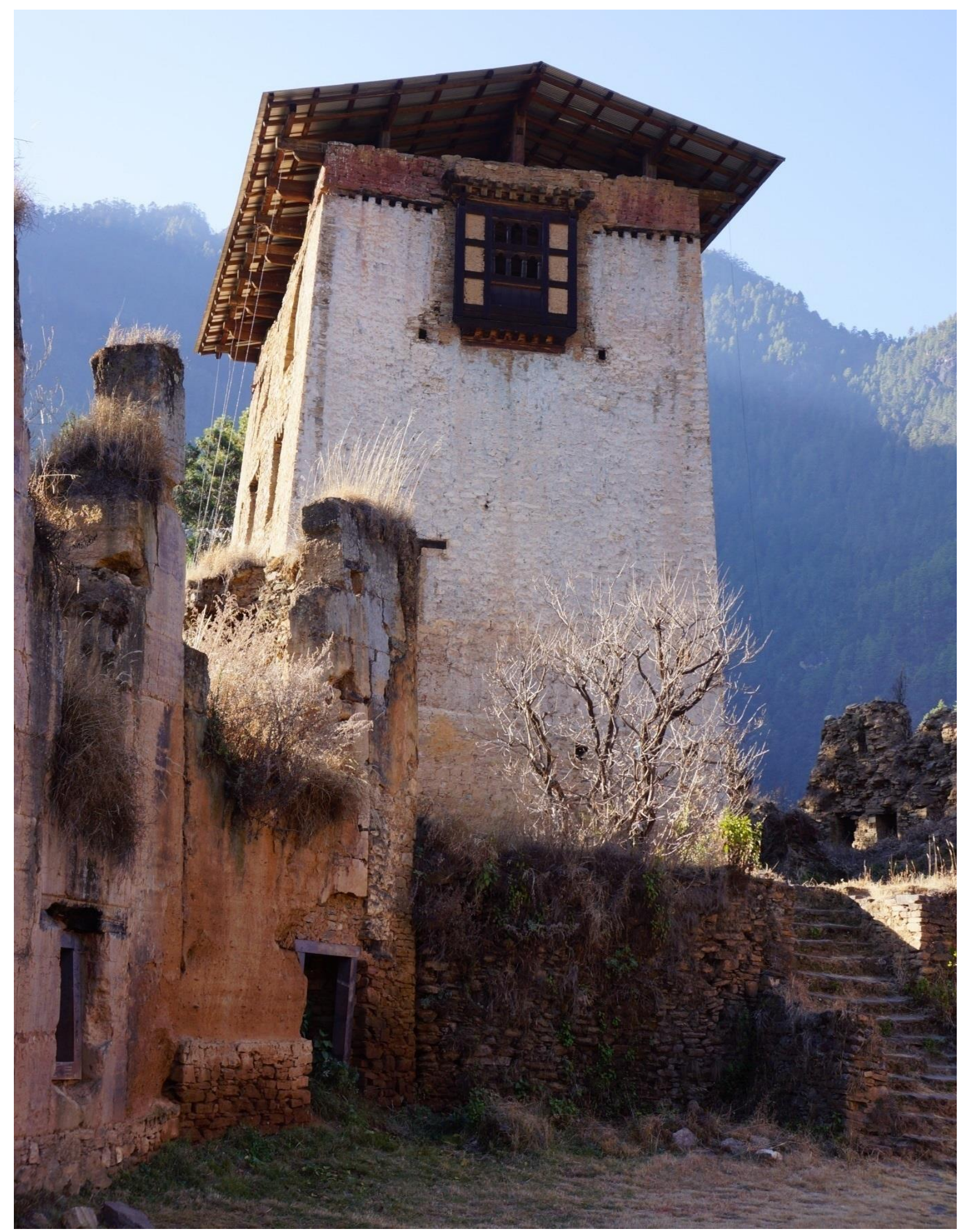

Figure 25. The central Utze.

All the monuments offered the opportunity to discuss approaches to documentation and especially the potential role of $3 \mathrm{D}$ recording systems, such as laser scanning and photogrammetry. These themes were picked up at a later workshop (see Section 4.5.5.2). 


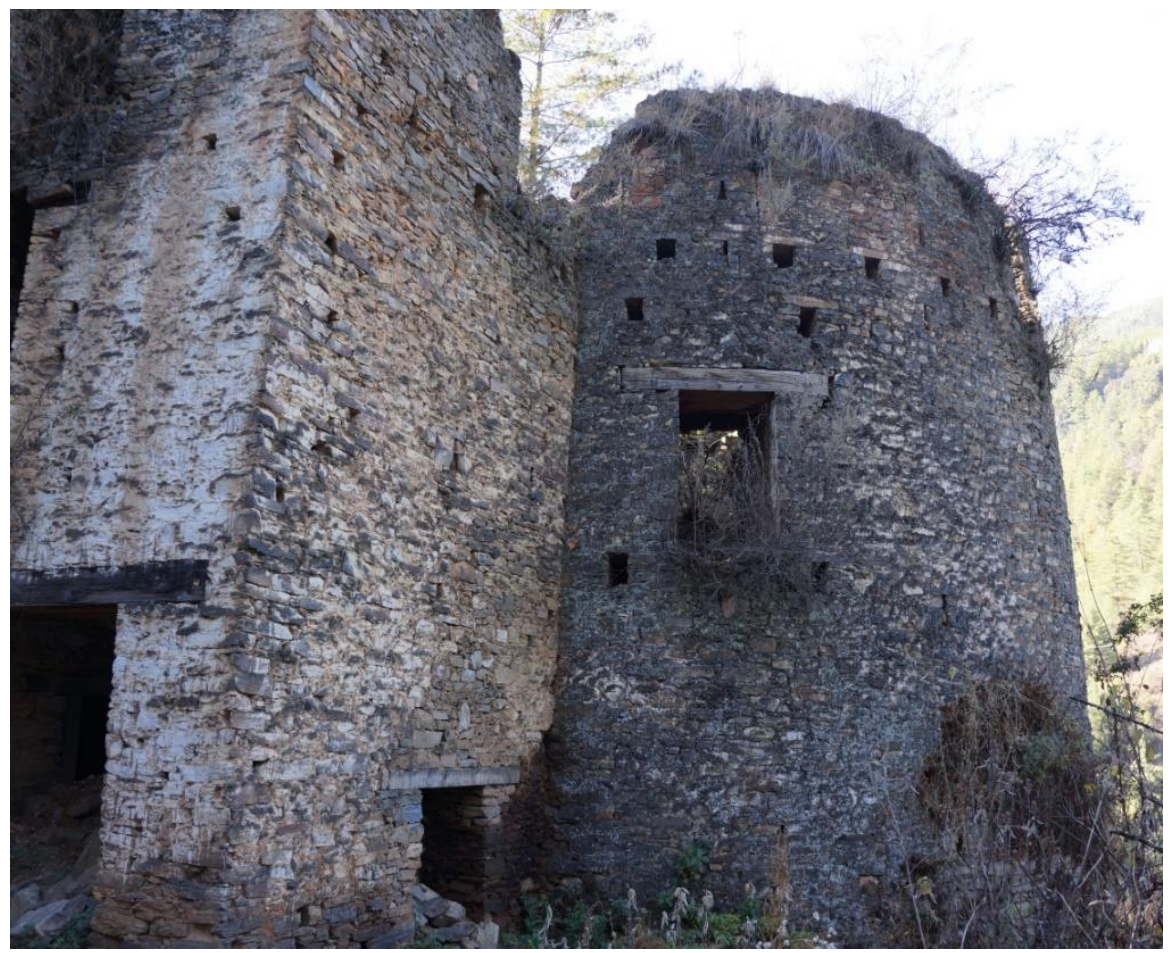

Figure 26. The outer works of Drukgyel Dzong, showing the difficulties of managing this large complex.

\subsubsection{Meeting with Minister for Home \& Cultural Affairs, Bhutan}

A very useful meeting took place with HE Damcho Dorji (Minister for Home \& Cultural Affairs, Royal Government of Bhutan) (Figure 27). This affirmed Bhutan's interest in developing capacity in the area of World Heritage nomination and the development of a National Inventory. In addition, the Minister discussed the planned Heritage Sites Bill of Bhutan, which aims to promote the protection, management and regulation of the heritage sites in the country. The measures proposed were warmly welcomed as a major step forward in heritage protection for the country.

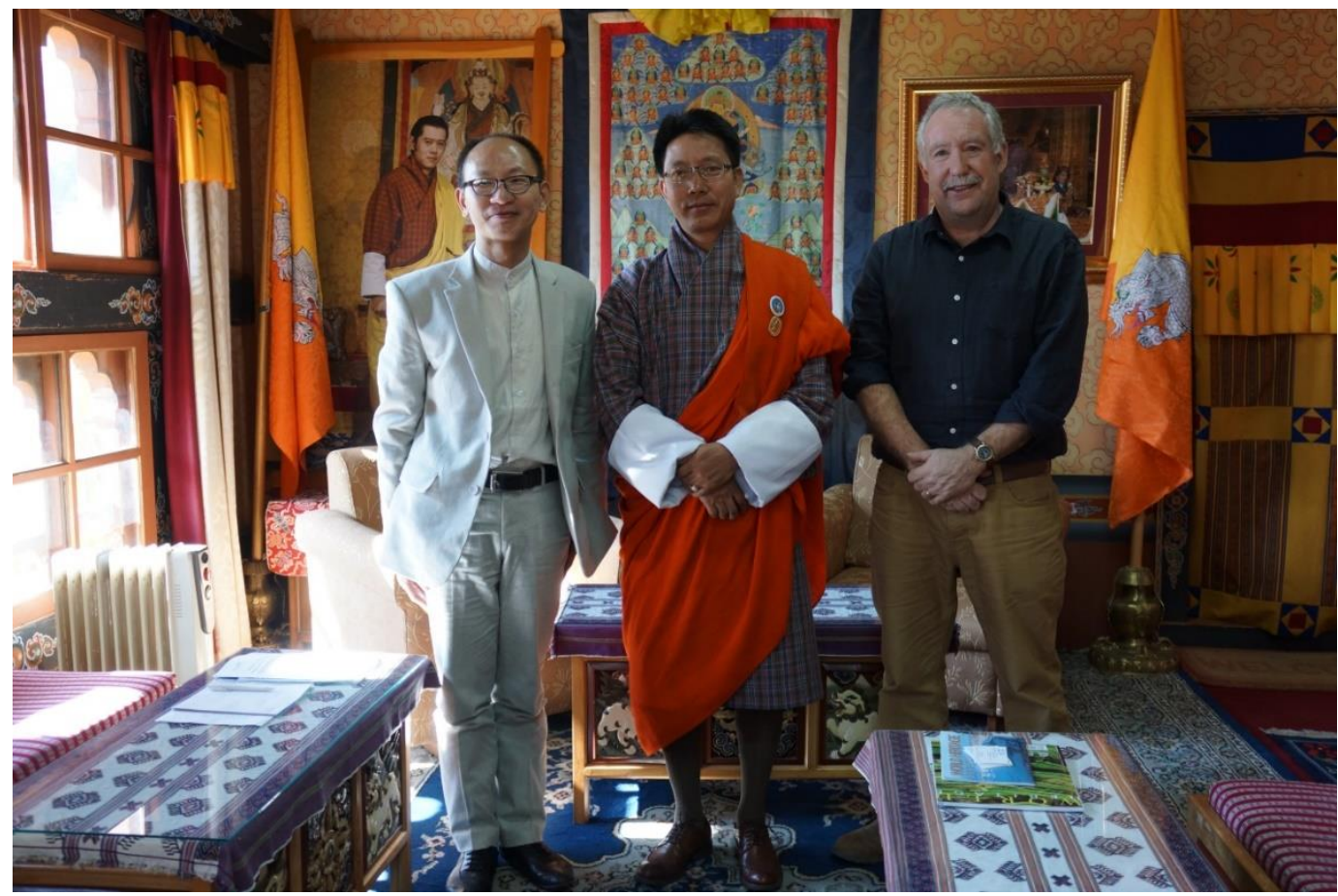

Figure 27. Meeting between His Excellency Damcho Dorji (Minister for Home \& Cultural Affairs, Royal Government of Bhutan), Roland Lin (UNESCO World Heritage Centre) and Tim Williams (University College London). 


\subsection{Delhi, India: 1-3 December 2013}

Tim Williams (UCL \& ICOMOS), in cooperation with Moe Chiba, Programme Specialist for Culture, UNESCO New Delhi Office, undertook a consultation meeting with the Archaeological Survey of India (ASI). The discussion reviewed India's Silk Roads Tentative List7 (Table 1 \& Figure 28). In addition, a number of existing sites on the tentative list, such as the Ancient Buddhist Site of Sarnath, Varanasi, Uttar Pradesh (submitted in 1998), would also be worth considering in the context of the Silk Roads nomination. The issue of the integration of existing World Heritage Sites within corridors, such as the Ajanta Caves (Figure 31), was also discussed.

Table 1. Indian tentative list 2010.

\begin{tabular}{|c|c|}
\hline Name of Property & State, Province or Region \\
\hline Ruins of Ancient Vaishali & Bihar, Vaishali \\
\hline Remains of Vikramshila Ancient University & Bihar, Bhagalpur \\
\hline Buddhist remains of Kushinagar & Uttar Pradesh, Kushinagar \\
\hline Sravasti & Uttar Pradesh, Sravasti \\
\hline Kaushambi & Uttar Pradesh, Kaushambi \\
\hline Ahichhatra & Uttar Pradesh, Ramnagar \\
\hline Ancient Site and Buddhist Stupa (Sanghol) & $\begin{array}{l}\text { Punjab, Fatehgarh Sahib, Tehsil- } \\
\text { Khamanu }\end{array}$ \\
\hline Arikamedu, Early Historic Site & Union Territory of Pondicherry \\
\hline $\begin{array}{l}\text { Excavated remains of Kaveripattinam (excavated } \\
\text { remains of Buddhist vihara and temple at } \\
\text { Pallavaneswaram-Melaiyur) }\end{array}$ & Tamil Nadu, Nagapattinam \\
\hline $\begin{array}{l}\text { Ancient monastery and stupa together with } \\
\text { adjacent land (Harwan) }\end{array}$ & Jammu \& Kashmir \\
\hline $\begin{array}{l}\text { Mound locally known as Burud Kot (Nalla Sopara } \\
\text { Stupa) Maharashtra }\end{array}$ & Tehsil-Vasai, Thane \\
\hline Indraprastha & NCT Delhi \\
\hline
\end{tabular}

7 India submitted a Silk Roads Sites in India list in 2010 - see http://whc.unesco.org/en/tentativelists/5492/ 


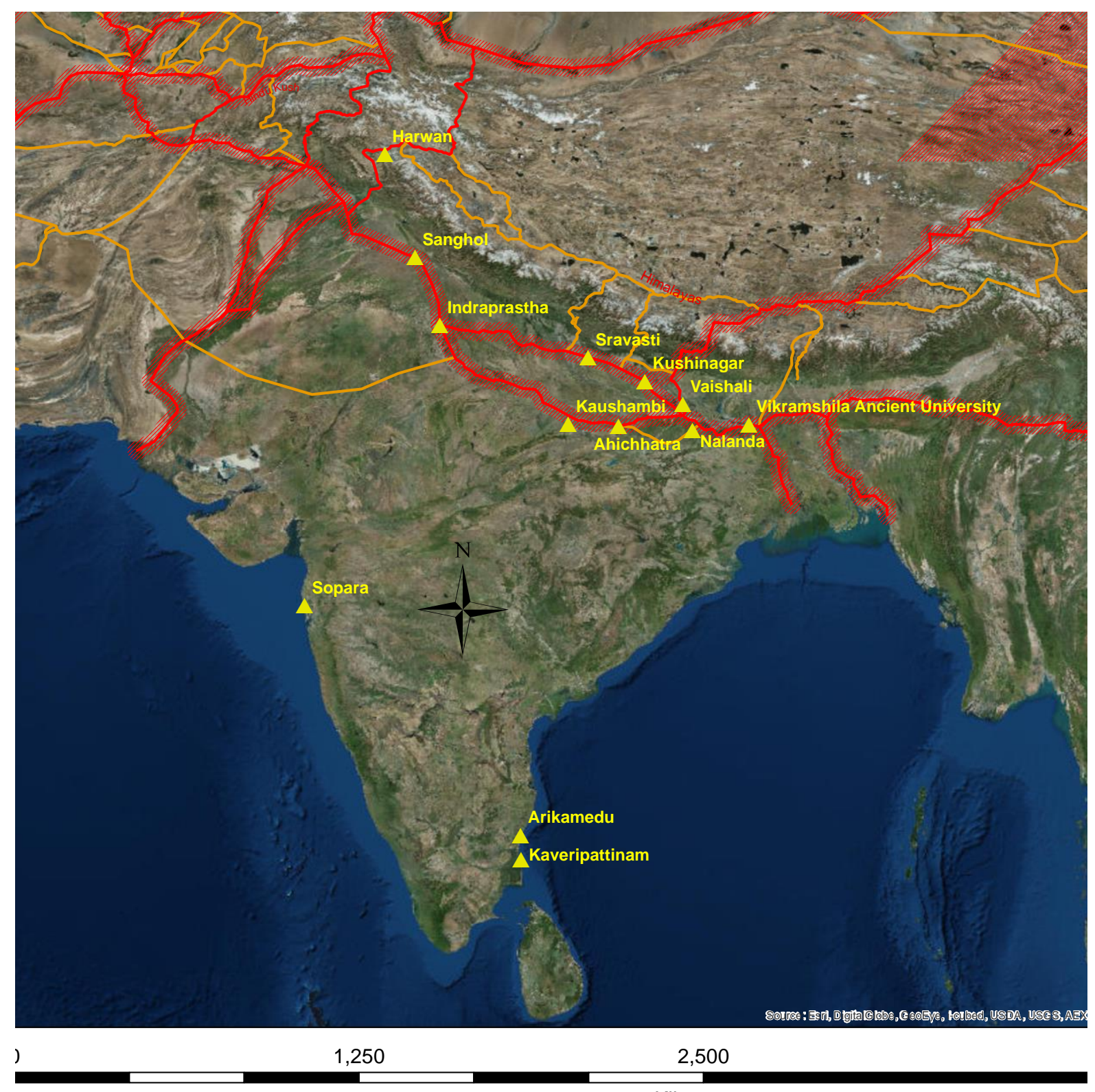

Kilometers

Figure 28. Indian tentative list sites (2010). 


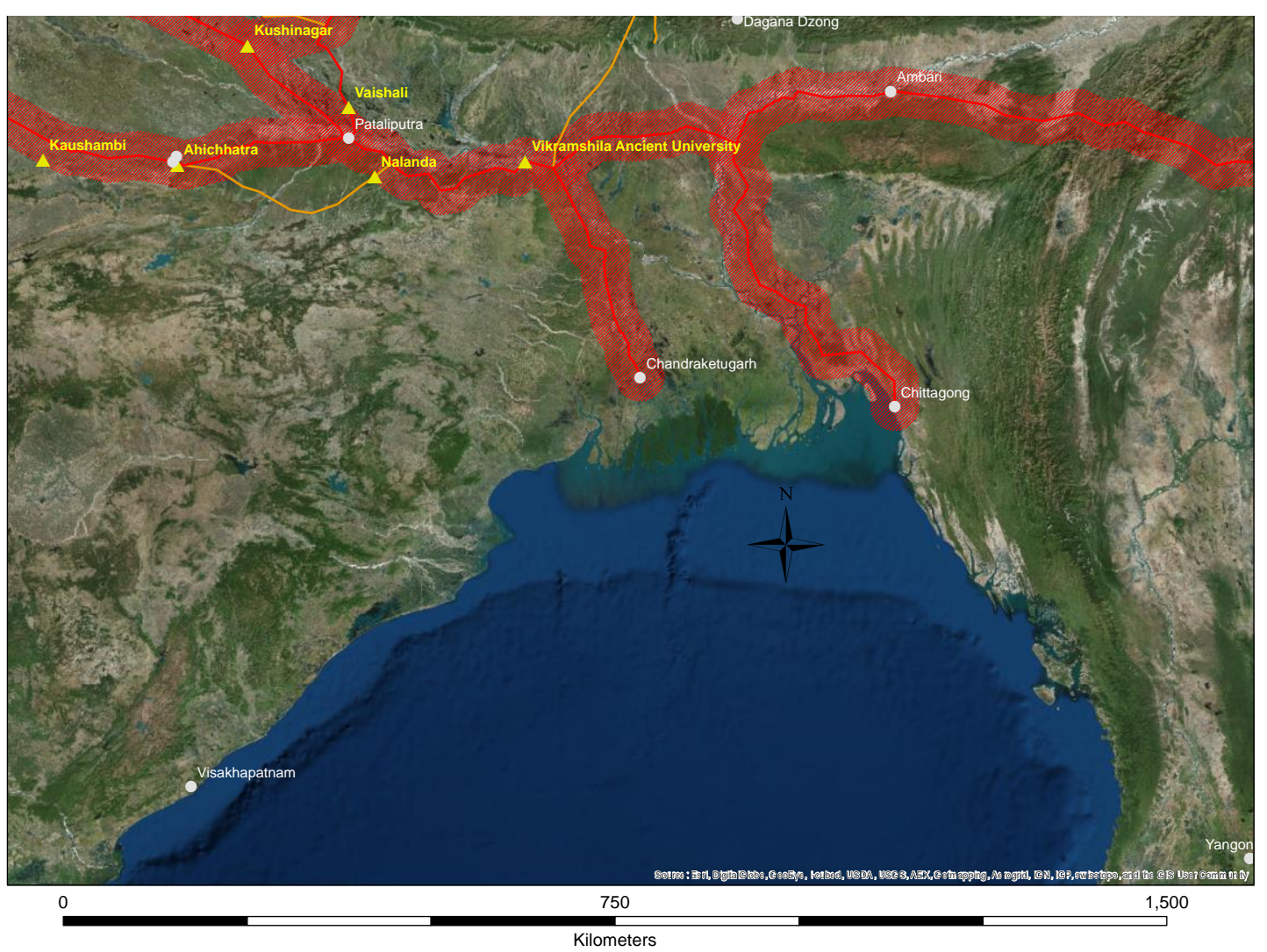

Figure 29. Northeast India, including links to the Bay of Bengal, and its important ports, such as Chandraketugarh, Visakhapatnam and Chittagong (Bangladesh).

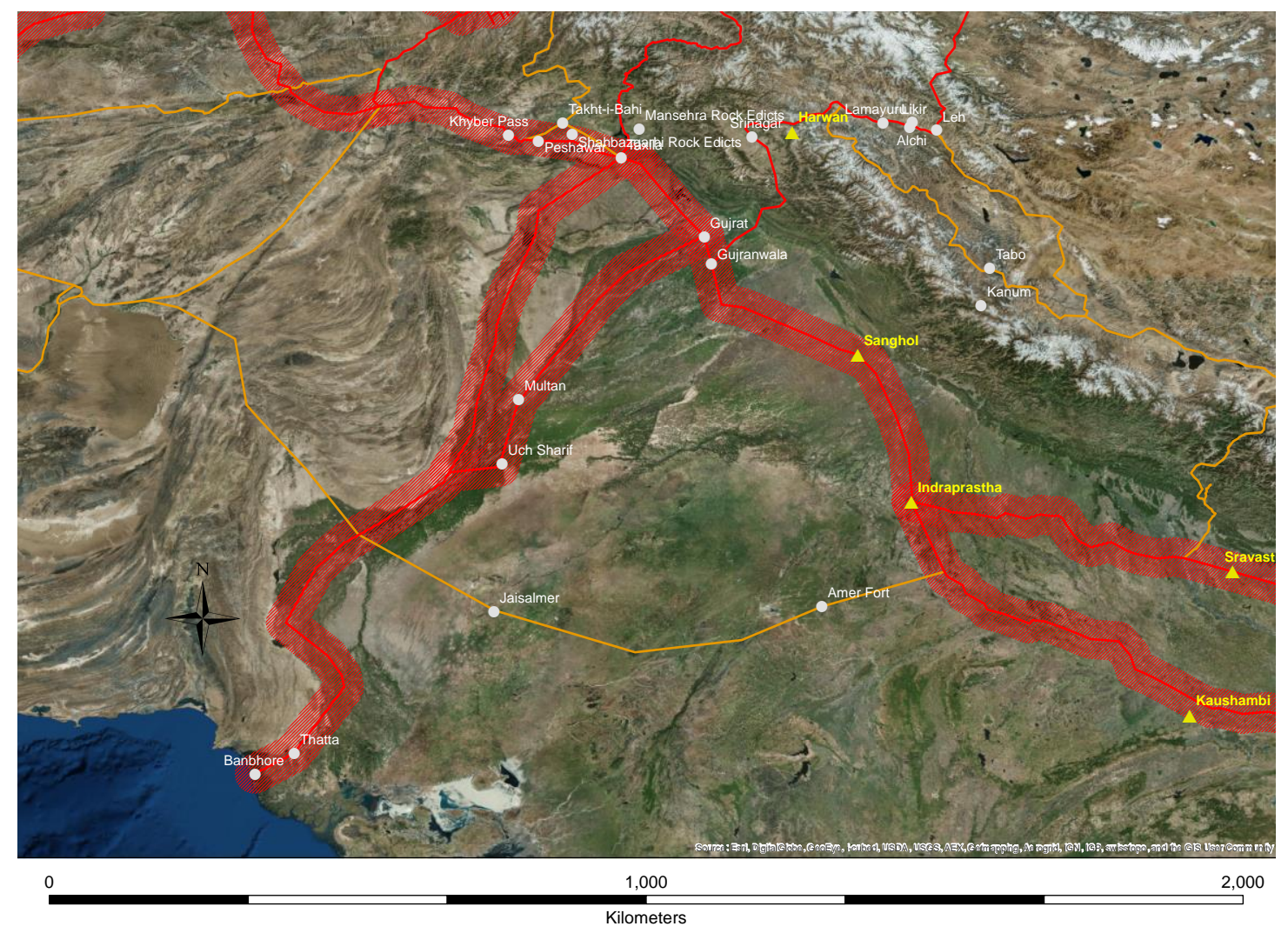

Figure 3o. Northwest India and Pakistan. 


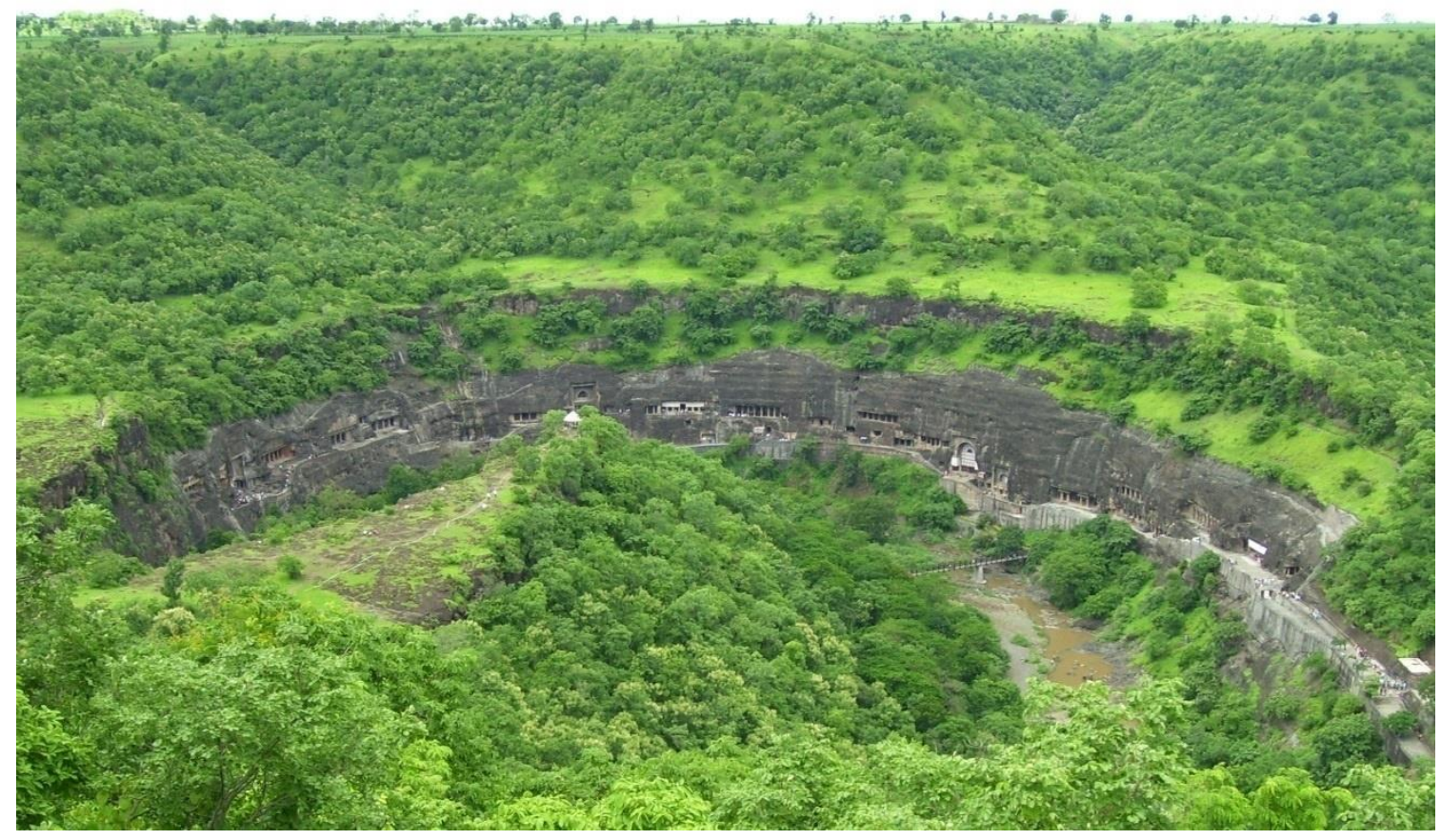

Figure 31. The World Heritage Site of the Ajanta Caves, Maharashtra, India ${ }^{8}$. The first Buddhist cave monuments at Ajanta date from the 2nd and ist centuries BCE, but during the Gupta period ( $5^{\text {th }}$ and 6th centuries $\mathrm{CE}$ ), richly decorated caves were added: masterpieces of Buddhist religious art (Photograph taken by Ashok [Freakyyash]. GNU Free Documentation License).

The integration of the routes with Nepal, Bangladesh, Pakistan and China was seen as an important issue. It was also agreed that links between the land routes and the maritime trade entrepôts was needed - India provides an important bridge between landward routes and maritime trade.

The meeting also took the opportunity to discuss India's role in the potential trans-boundary activities of the UNESCO/Korean FIT Project with Bhutan, China, and Nepal. Issues discussed included furthering the development of mechanisms for the cooperation and dialogue between the four States Parties involved in the project, and to support India's input on the South Asian Silk Roads World Heritage Nomination Strategy. The meeting recognised the importance of the involvement of both UNESCO New Delhi and ASI in the on-going project. 


\subsection{Thimphu, Bhutan: 20-22 August 2014}

\subsubsection{Introduction}

The first consultation meeting conducted by UNESCO (WHC/HQ) in December 2013 identified the need of the Government of Bhutan to improve the current inventory and data management system in view of the effective preparation of the future World Heritage nomination. Accordingly, an introductory 3-day training workshop on 'National Inventory and the Silk Roads' was organized in August 2014 in the National Library, Thimphu.

A student cultural landscape competition also enabled some UCL students to participate in the workshop.

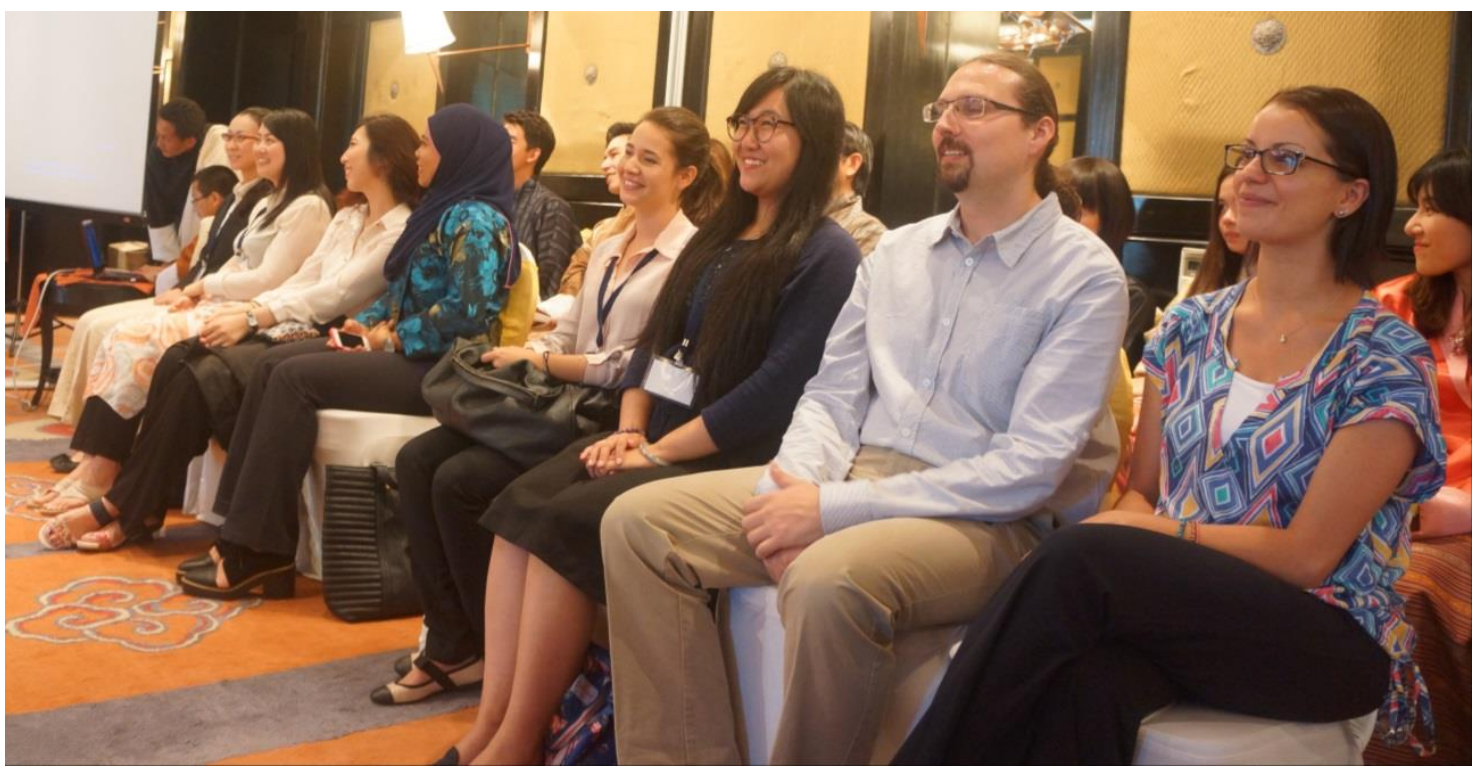

Figure 32. Students from UCL and other participating Universities at the cultural landscape competition.

\subsubsection{Participants}

The workshop involved staff of the Division for Conservation of Heritage Sites (DCHS), within the Department of Culture of the Ministry of Home and Cultural Affairs (MoHCA), and a team from the Institute of Archaeology, University College London (UCL). Prof Roland Lin (UNESCO World Heritage Centre) also attended the initial meetings.

The participation of the UCL team in the workshop was generously supported by the KoreanFunds-in-Trust, with the support of UNESCO World Heritage Centre (Paris) and UNESCO Office New Delhi.

\begin{tabular}{|ll|}
\hline Name & \multicolumn{1}{|c|}{ Specialism } \\
\hline MoHCA, Division for Conservation of Heritage Sites \\
\hline Mrs. Nagtsho Dorji & $\begin{array}{l}\text { Head/ Chief Architect: Overall supervision and decision making } \\
\text { for DCHS works }\end{array}$ \\
\hline Mr. Choening Dorji & Senior Architect: responsibility for Heritage Sites bills \\
\hline Mr. Yeshi Samdrup & Architect: special responsibility for World Heritage and Silk Roads \\
\hline Mr. Karma Tenzin & Architect: special responsibility for archaeology \\
\hline Mr. Sangay Kinga & $\begin{array}{l}\text { Assistant Architect: special responsibility for the National } \\
\text { Inventory, Archaeology and Focal Point 'Bhutan Periodic } \\
\text { Reporting' to UNESCO WHC }\end{array}$ \\
\hline
\end{tabular}




\begin{tabular}{|ll|}
\hline Ms. Sonam Zangmo & $\begin{array}{l}\text { IT Officer: Responsible For DCHS webpage development, to } \\
\text { backup for Database and inventory of heritage sites system } \\
\text { development }\end{array}$ \\
\hline UCL & $\begin{array}{l}\text { Senior Lecturer: Specialist in site management planning, World } \\
\text { Heritage nomination and the Silk Roads }\end{array}$ \\
\hline Tim Williams & Senior Lecturer: Specialist in GIS systems and spatial analysis \\
\hline Prof Andrew Bevan & Specialist in national inventories \\
\hline Dr Adi Keinan-Schoonbaert & Cultural heritage database specialist \\
\hline $\begin{array}{l}\text { Bryan Alvey (Cultural } \\
\text { Heritage Information }\end{array}$ & MA student: Managing Archaeological Sites \\
\hline UCL Student observers & MA student: Managing Archaeological Sites \\
\hline Albert Llanas Girones & MA student: Cultural Heritage Studies \\
\hline Shaochen Wang & World Heritage specialist (Asia \& Pacific Unit, World Heritage \\
\hline Ana Sabina Cioboata & Centre) \\
\hline UNESCO & Programme Specialist for Culture, UNESCO New Delhi Office \\
\hline Dr Roland Lin Chih-Hung & \\
\hline Moe Chiba &
\end{tabular}

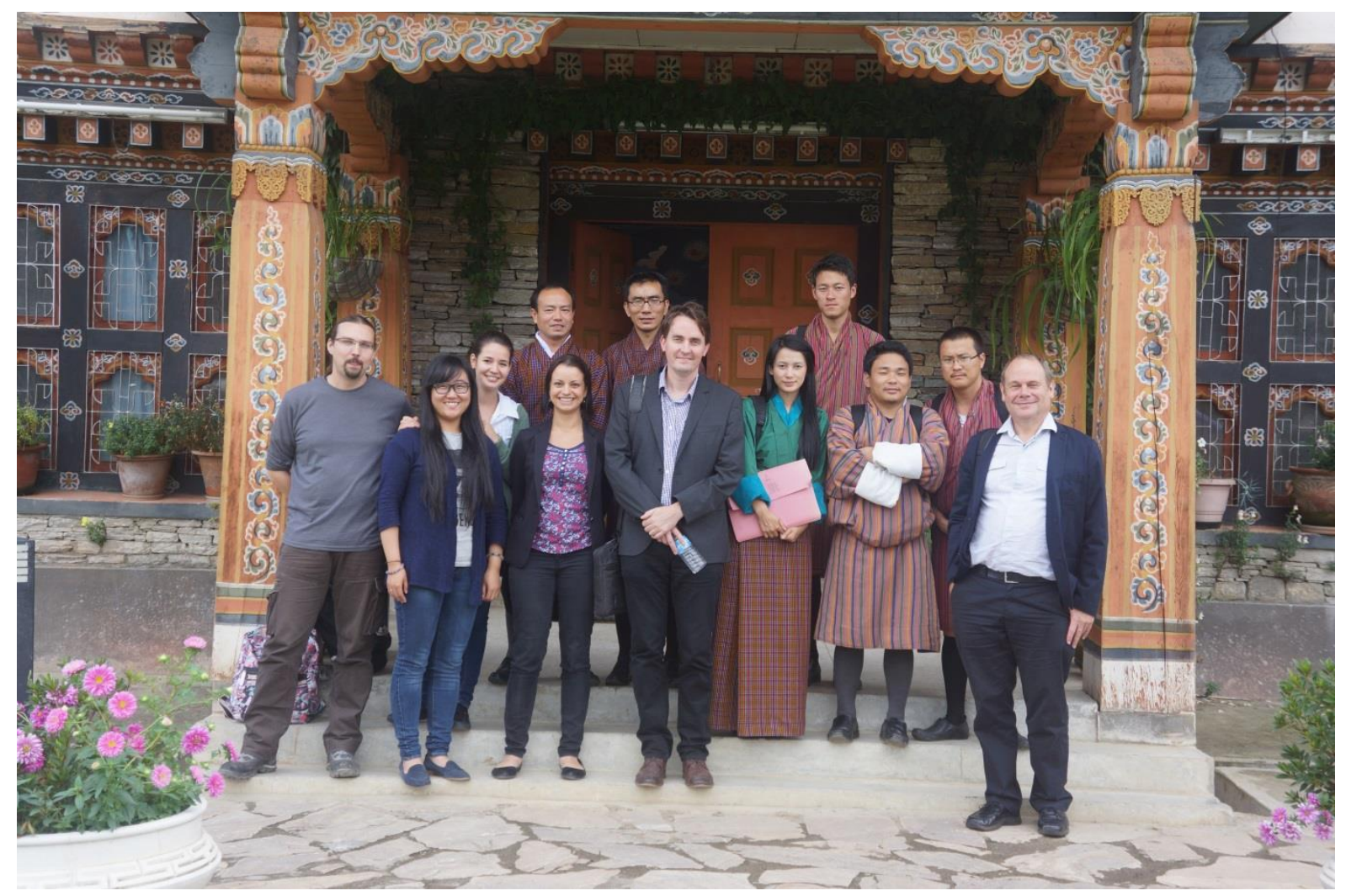

Figure 33. The workshop members outside the National Archive building.

\subsubsection{Aims of the workshop}

The primary aim of the workshop was to explore strategies for the development of a National Inventory system for Bhutan. A National Inventory was seen as a fundamental platform for increasing and disseminating awareness of Bhutanese heritage, for developing approaches to the protection of heritage, and for underpinning the selection and management of monuments, sites and landscapes as part of any World Heritage nomination process.

The specific aims of the workshop were to: 
1) National inventory systems

a. Examine international approaches to national inventories

i. Aims

ii. Function and development

iii. Structure and content

iv. Security \& archiving

b. Explore Bhutan's needs

i. Legislative frameworks

ii. Inventory aims

iii. Using spatial data and geographic/landscape tools

iv. Database management

c. Demonstrate the ARCHES system - as an example of a digital inventory system and to consider whether it could be adapted to Bhutan's needs

d. Examine existing Bhutanese data

i. Existing digital data

ii. Existing catalogues \& inventories

iii. Spatial/mapping \& cartographic

iv. Data in other institutions

e. Discuss options and forward strategy

i. ARCHES - does this meet the needs?

ii. Strategies for system development

iii. Strategies for data collection

iv. Strategies for capacity building \& resourcing

2) The serial nomination of Dzongs to the World Heritage List

a. Discuss documentation, management planning, buffer zones, authenticity and nomination dossier compilation issues

b. Digital documentation: review of 3D scanning, LiDAR, and other photographic documentation approaches

3) The Silk Roads project: Discussion of South Asian Silk Roads project

a. World Heritage Serial Trans-boundary nomination

b. International and sub-regional collaboration

c. Types of monuments, sites and cultural landscapes

d. Developing inventories/documentation.

\subsubsection{Programme}

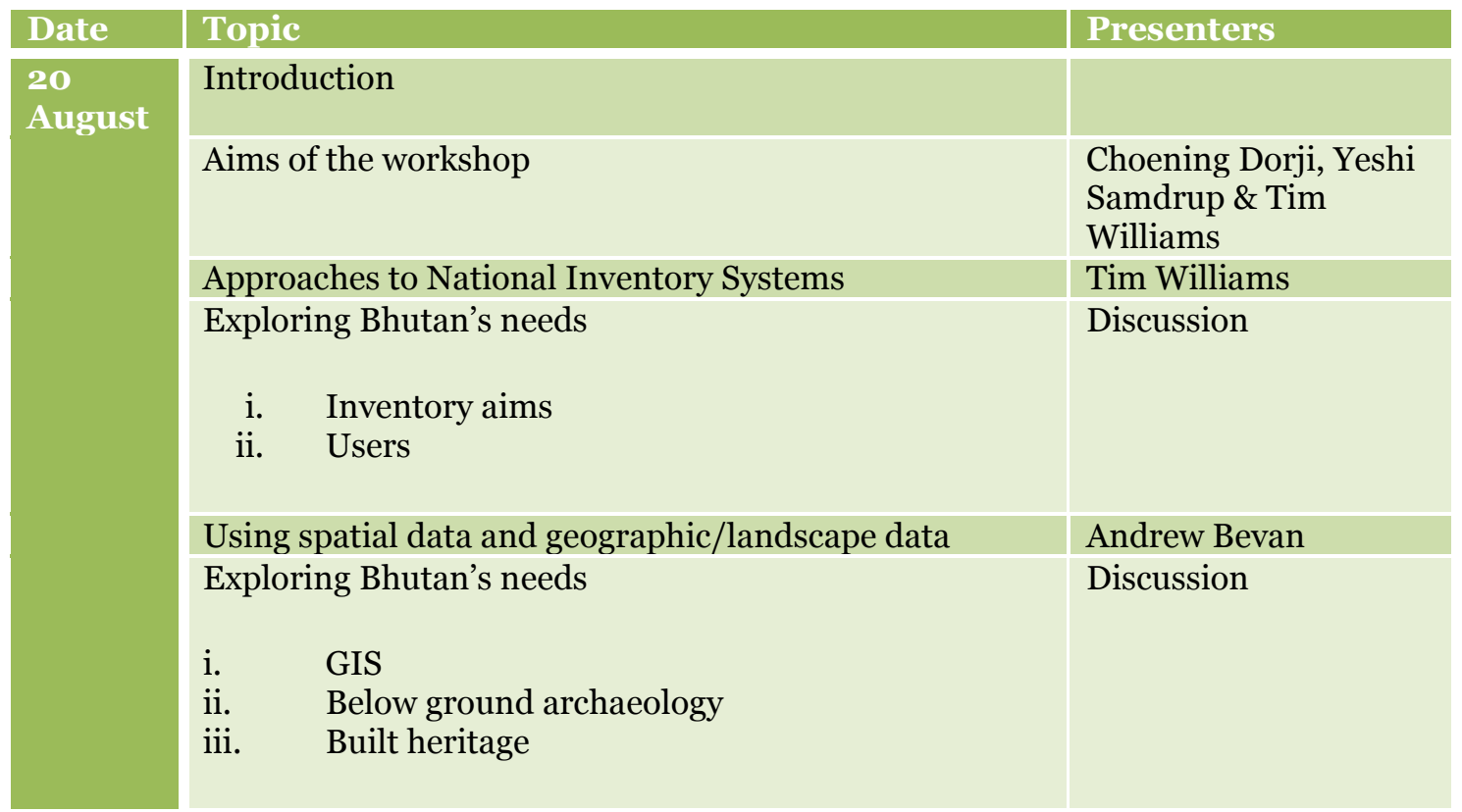




\begin{tabular}{|c|c|c|}
\hline & Demonstration of the ARCHES system & Bryan Alvey \\
\hline & $\begin{array}{l}\text { The adaption and suitability of the ARCHES system for } \\
\text { Bhutan }\end{array}$ & Discussion \\
\hline & Documentation & \\
\hline & $\begin{array}{l}\text { Building and landscape documentation - laser } \\
\text { scanning, LiDAR, photogrammetry, photographic } \\
\text { manipulation, etc. }\end{array}$ & $\begin{array}{l}\text { Adi Keinan- } \\
\text { Schoonbaert }\end{array}$ \\
\hline & $\begin{array}{l}\text { Hands-on demonstration of structure-from-motion } 3 \mathrm{D} \\
\text { modelling }\end{array}$ & Andrew Bevan \\
\hline & Review of software \& options & Discussion \\
\hline & Forward strategy & Discussion \\
\hline & $\begin{aligned} \text { i. } & \text { Priorities } \\
\text { ii. } & \text { Consideration of database system } \\
\text { iii. } & \text { Future strategies for a National Inventory } \\
\text { iv. } & \text { Strategies for data collection } \\
\text { v. } & \text { Capacity building } \\
\text { vi. } & \text { Fund raising }\end{aligned}$ & \\
\hline & Examining existing Bhutanese data & Discussion \\
\hline & $\begin{aligned} \text { i. } & \text { Existing catalogues \& inventories } \\
\text { ii. } & \text { Existing mapping \& cartographic data } \\
\text { iii. } & \text { Documentary evidence } \\
\text { iv. } & \text { Portable heritage } \\
\text { v. } & \text { Intangible heritage } \\
\text { vi. } & \text { Cultural landscapes } \\
\text { vii. } & \text { Satellite imagery }\end{aligned}$ & \\
\hline & The South Asian Silk Roads project & Tim Williams \\
\hline & Conclusions & \\
\hline $\begin{array}{l}22 \\
\text { August }\end{array}$ & $\begin{array}{l}\text { Dzongs serial nomination: Visit to Punakha Dzong } \\
\text { Discussion of: }\end{array}$ & \\
\hline & $\begin{array}{l}\text { i. From National inventory to management } \\
\text { strategies } \\
\text { ii. Management planning } \\
\text { iii. The application of scanning technologies to } \\
\text { Dzong documentation }\end{array}$ & \\
\hline $\begin{array}{l}23 \\
\text { August }\end{array}$ & $\begin{array}{l}\text { Examination of National Inventory \& Silk Roads } \\
\text { material in the MoHCA offices }\end{array}$ & \\
\hline
\end{tabular}

\subsubsection{Summary \& key issues}

\section{5•5.1 National Inventory}

There was a detailed discussion of the need for, and aims of, a national inventory system for Bhutan. General agreement was reached on both the importance of the development, and its aims. These can be broadly summarised as:

1. To disseminate information and raise awareness of cultural heritage sites in Bhutan; to both national and international audiences

2. To create a knowledge-based context for the preservation, promotion and management of 
cultural heritage in Bhutan

3. To document the condition, state of conservation, management planning, and changing circumstances of the heritage in Bhutan

4. To provide a robust under-pinning for the selection of monuments, sites and landscapes for any potential World Heritage nomination.

It was agreed that the Inventory should reflect the three categories of cultural heritage specified in the current draft legislation (Heritage Sites Bill of Bhutan):

- Heritage Buildings (including sub-categories of religious buildings, vernacular architecture, etc.);

- Archaeological Sites;

- Cultural Sites (which encompass landscape areas and agglomerations of historic and archaeological elements) 9 .

The ARCHES system ${ }^{10}$ was extensively reviewed. It had been developed as a bespoke heritage inventory platform, based on heritage inventories in the Middle East, and developed with the support of the Getty Conservation Institute and the World Monuments Fund (Carlisle et al. 2014; Myers et al. 2012; Myers et al. 2013).

It was agreed that the system provided an acceptable platform to develop a Bhutanese National Inventory. It would require some customisation, but was adaptable to the specific needs of Bhutan, and considerably more cost effective, and easier to implement, than developing a new bespoke application.

A way forward with the development of the system was discussed and agreed in principle. This envisaged an operational system for testing by the spring of 2015 and a fully functioning system for more intensive data entry/digitisation being operational by the autumn of 2015 . The scale of work to add data to the system, and the ability of the resulting online inventory deliver a sufficient body of data to the general public, will depend upon the scale of resources available for data entry, scanning and checking. It is likely to be a long-term activity. As a result, it will be essential that the DCHS establish a clear set of priorities, based on the expected development challenges facing Bhutan.

\subsubsection{Digital documentation: the serial nomination of Dzongs as the centre of temporal and religious authorities}

Detailed discussion took place regarding approaches to building and landscape documentation, which would be a crucial aspect of developing any serial nomination for the Dzongs. The strengths and weaknesses of $3 \mathrm{D}$ laser scanning, LiDAR and photogrammetry (including photographic modelling ${ }^{11}$ ) were discussed, and examples presented. This led to discussion of:

i) The possibility of interesting international partners (Leica, CyArk and the World Monuments Fund (WMF)) in laser scanning the Dzongs which have been selected for the World Heritage Tentative List serial nomination (Punakha Dzong, Wangdue

\footnotetext{
9 Defined in the draft Bill as "that includes heritage villages, and other broad area and landscape which are part of living cultural traditions and other intangible aspect of our heritage". Elsewhere these have often been defined as 'Cultural Landscapes', although in Bhutan this concept has been applied to the whole country.

${ }^{10}$ See http://archesproject.org/

${ }^{11}$ Photographic-based methods using cross-photo matching to establishing camera position, rather than a fixed rig or targets.
} 
Phodrang Dzong ${ }^{12}$, Paro Dzong, Trongsa Dzong and Dagana Dzong); as well as the Ancient Ruin of Drukgyel Dzong. Laser scanning of the monuments would be a significant task, given their architectural form and interior/exterior complexities.

ii) The use of cheaper $3 \mathrm{D}$ photographic modelling systems for specific aspects on monument documentation. This has a strong potential to develop low cost and easily implemented documentation initiatives. It may be particularly useful for building documentation and/or conservation related projects. It can be developed using existing digital cameras within the DCHS and free software, although a copy of Agisoft PhotoScan Professional edition ${ }^{13}$ would be useful to develop the full functionality of the modelling. It would also be interesting to acquire for the DCHS a small remote controlled helicopter to capture high level photographs of standing structures, and assist in wider terrain modelling.

The issues of supporting capacity building were also raised. Training tutorials were supplied to support the $3 \mathrm{D}$ photographic modelling approaches, but one or more short courses might also be useful. In addition, any externally supported programme of laser scanning should include some training and capacity building elements.
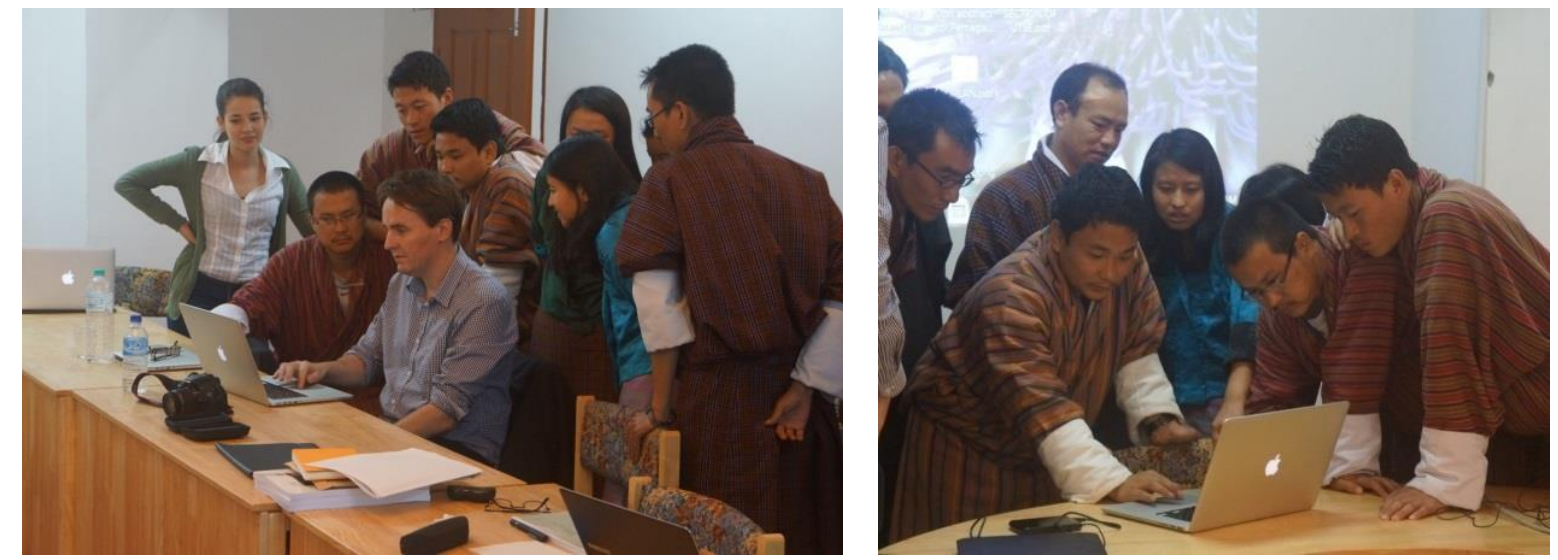

Figure 34. Examining 3D photographic software and scanning options.

\subsubsection{Boundaries and buffer zones}

The issue of boundaries and buffer zones was discussed - and the use of GIS modelling (e.g. defining a zone of relevance around each monument that relates to its visual territory or pedestrian travel times) was suggested as a means of relating work on the National Inventory to the nomination strategy (See Bhutan National Inventory project - see Section 1).

\subsubsection{Bhutan and the South Asian Silk Roads project}

The advantages of sub-regional collaboration were discussed, as a mechanism to enable Bhutan to participate in capacity building exercises, and to discuss with colleagues about possible approaches to heritage management, conservation approaches (for example regarding earthen architecture) and site/route selection. It was felt that this would be of benefit both to the long-term possibility of a Silk Roads nomination, but would also assist the processes and actions that would underpin any World Heritage nomination from Bhutan (for example, the Dzongs: the centre of temporal and religious authorities).

The possible routes and sites/monuments/landscapes in Bhutan were discussed. The National

${ }^{12}$ Given the tragic fire at Wangdue Phodrang Dzong in 2012, and the current rebuilding programme, it might be useful to scan the ruins/existing fabric before restoration is too far advanced.

${ }^{13} \mathrm{http}: / /$ www.agisoft.ru/products/photoscan/professional 
Inventory system will be important in providing a platform to discuss site selection, but it was also recognised that Bhutan currently has limited documentation about pre-17th century sites and that it is likely that the identification of specific sites and landscapes would therefore take some time. Indeed, there are numerous challenges to developing a Silk Roads strategy for Bhutan. The most fundamental is the lack of current research on pre- $17^{\text {th }}$ century archaeology, with the lack of data making the identification of routes and specific sites/monuments or landscapes for inclusion difficult at this stage. The potential is clearly high: modern-day Bhutan occupies a crucial strategic position on the routes both from Tibetan Sichuan and Yunnan (e.g. Tea Horse routes) and from Tibet down the 'southern valley' systems (e.g. Salt routes) to India and Bangladesh. The foundation of early monastic settlements (e.g. the documentary sources suggesting the foundation of the mediation centre at Taktsang Palphug Monastery in the $8^{\text {th }}$ century CE; or the foundation of Choedrak Monastery in the $12^{\text {th }}$ century, or Phajoding monastery in the $13^{\text {th }}$ century) reinforce the sense that there was a developed settlement pattern in the fertile valleys of Bhutan that significantly pre-dates the current monuments (Figure 35). The Dzongs constructed as part of the unification of Bhutan after 1616 by Zhabdrung Ngawang Namgyel were evidently securing existing polities in the important valley systems of western and central Bhutan.

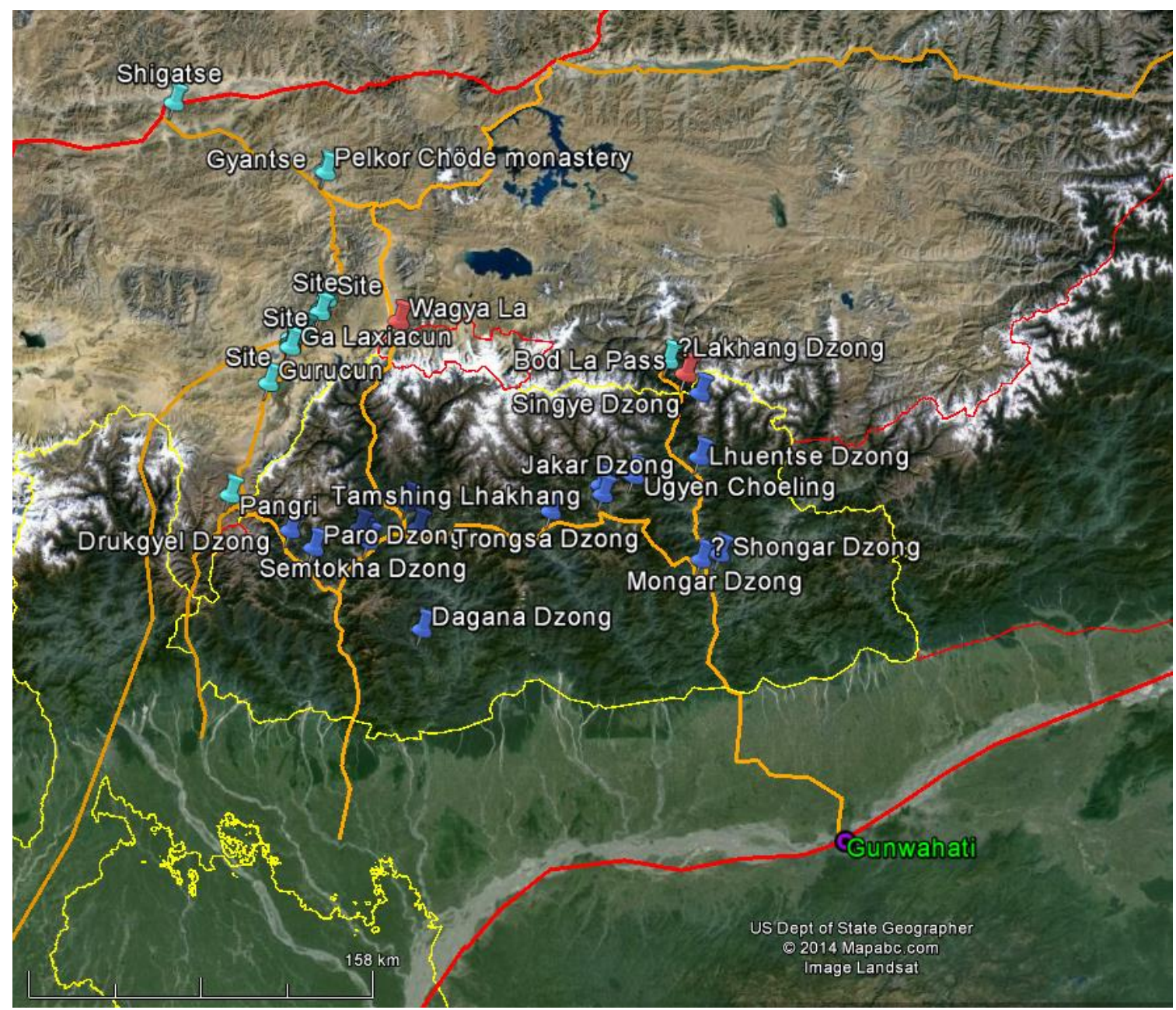

Figure 35. Possible routes through and near Bhutan, based on later sites controlling mountain valleys and passes.

There are some fundamental research issues confronting the development of the component of the National Inventory pre-dating the $17^{\text {th }}$ century, not least the limited amount of archaeological work and the concomitant problems of understanding early material culture. There is a lack of research into ceramics, radiocarbon or artefact-based dating evidence, etc., 
compounded by the apparent continuity of material traditions in cooking vessels - and the use of metalwork and wood for high prestige goods and the use of leather sacks for storage ${ }^{14}$, all of which have significant problems of survival in the archaeological record. However, significant quantities of ceramics were recovered during the recent Swiss-Bhutanese project (Yeshi Samdrup pers. comm.), which suggests that it may well be possible to develop a regional ceramic sequence. In addition, the recently published research on Ogyen Choling (Choden \& Roder 2012) demonstrates the complexity of landscapes and routes, and the ability of local studies to begin to understand the development of earlier settlement landscapes.

\subsubsection{Recommendations for further action}

\section{4-5.6.1 National inventory system}

See Section 1.

\section{4-5.6.2 Digital documentation strategies}

It is suggested that DCHS, in partnership with UCL:

- Formulate an application to the CyArk 500 Challenge ${ }^{15}$

- Develop an outline strategy paper to provide the basis for opening discussions with Leica, CyArk and the World Monuments Fund over the detailed documentation of the selected Dzongs. Any such strategy would need to address:

- data capture in the field

- the processing of the point cloud and high-resolution imagery

- the archiving of the data

- reinforcing the ability of the DCHS to manipulate the data and produce architectural drawings ${ }^{16}$.

Photographic document - 3D imaging: DCHS to experiment with $3 \mathrm{D}$ photographic documentation, based on training tutorials supplied.

UCL, in partnership with DCHS, to explore funding for a trial project of photographic documentation, to compare with the $3 \mathrm{D}$ laser scanning (above). This would involve training of DCHS staff, the purchase of the necessary software and a remote controlled helicopter.

\subsubsection{Bhutan and the South Asian Silk Roads project}

The participation of Bhutan in the forthcoming sub-regional workshop, to be held in Nepal in September 2014, will enable wider dialogue with colleagues from the neighbouring countries and discussion of approaches to trans-boundary working.

UCL will assist the DCHS in preparing a concept paper for the Silk Roads in Bhutan, which will consider the approach to developing a platform of information upon which to consider possible routes and site/monument/landscape identification. This will be a long-term activity.

(See South Asian Nomination Strategy - Appendix 1.)

\footnotetext{
14 The Folk Heritage Museum, Thimphu.

15 http://archive.cyark.org/submit-site

16 The background of DCHS staff in architecture, and the use of drafting programs such as AutoCAD, makes this more easily achieved.
} 


\subsection{Nepal: facilitation and technical support for Nepali national Silk Roads activities in 2014}

\subsubsection{Introduction}

A contract was issued with the Department of Archaeology (DoA), Nepal, to facilitate and provide technical support for Nepali national Silk Roads activities in 2014. This was extended up to May 2015 to ensure better results.

\subsubsection{Aims}

The implementation activities included:

- the organisation of national consultation meetings at nodal cities and districts along the identified Nepali heritage corridors;

- undertaking field expedition/field research in January 2015 for inventory preparation (see Section 1);

- documentation of identified priority Nepali corridors.

\subsubsection{Co-ordination}

A Nepali National Coordination Committee for the Silk Roads was established in January 2014 to oversee the national Silk Roads activities. The coordination committee included DoA staff, from relevant sections, representative from the Ministry of Culture, invited national experts, and relevant government departments and institutions (including UNESCO Kathmandu). The first meeting was held on 19 February 2014. It reviewed activities carried out by DoA and discussed plans for the future development. The meeting suggested exploring the 'postal routes - hulaki marg' from Kathmandu to western Nepal, in cooperation with the Postal Services Department. It also suggested taking necessary action to protect evidence along the Lumbini-Mustang corridor, especially the petro-glyphs, rock-shelter, rock-hewn walkway and painted caves, which are highly vulnerable due to planned road construction. Provisions for the legal protection of sites along the corridors is included in the next amendments that DoA are considering for the update of the national heritage legislation, the Ancient Monument Preservation Act 2013 (1956), which would be further discussed at the 2015 meetings.

The National Coordination Committee, formed at a departmental level, met five times to review progress and consider future directions. However, it lacked clearly defined functional roles, responsibilities and authority for decision-making. It was considered important that it was recognised at ministerial level, to support inter-departmental/inter-ministerial cooperation. In consultation with national experts, the DoA prepared a revised coordination structure to obtain this ministerial endorsement.

In addition, a focal person was nominated in April 2014 to advance and facilitate the SouthAsian Silk Roads activities in Nepal. A series of in-house consultations, including a sensitization meeting among the members, were held to discuss the preparatory activities for the planned sub-regional meeting to be hosted by Nepal in 23 and 24 September 2014 (see below).

\subsubsection{Documentation centre}

Within the framework of these national activities, the DoA purchased some 50 books related to Silk Roads, and established a Documentation Centre to house existing archives (including photographs, drawings, maps, etc.), and other records related to the Silk Roads heritage 
corridors through Nepal.

\subsubsection{Potential collaborations with ICIMOD}

In 2014, UNESCO also facilitated a meeting between the DoA and the International Centre for Integrated Mountain Development (ICIMOD), to explore possible collaboration. This highlighted ICIMOD's interest in the Kailash Sacred Landscape Conservation and Development Initiative as a potential World Heritage nomination. A follow-up meeting was held with ICIMOD experts to discuss the scientific documentation of cultural heritage along the corridor(s), although these discussions have not yet yielded any joint initiatives.

\subsection{Kathmandu, Nepal: 23-24 September 2014}

\subsubsection{Introduction}

A sub-regional workshop on the Nomination Strategy for the South Asian Silk Roads, supported by UNESCO/Korean Funds-In-Trust Project, was co-organised by the UNESCO World Heritage Centre, the UNESCO Office in Kathmandu and the Department of Archaeology, Ministry of Culture, Tourism and Civil Aviation of Nepal. The meeting was held in the Hotel Annapurna, Kathmandu, Nepal.

The workshop brought together national representatives and experts from four South Asian countries (Bhutan, China, India and Nepal), an international expert, UNESCO representatives and about 60 national participants from the host country, Nepal, to discuss the potential serial and transnational World Heritage nomination of the Silk Roads cultural routes network in South Asia ${ }^{17}$.
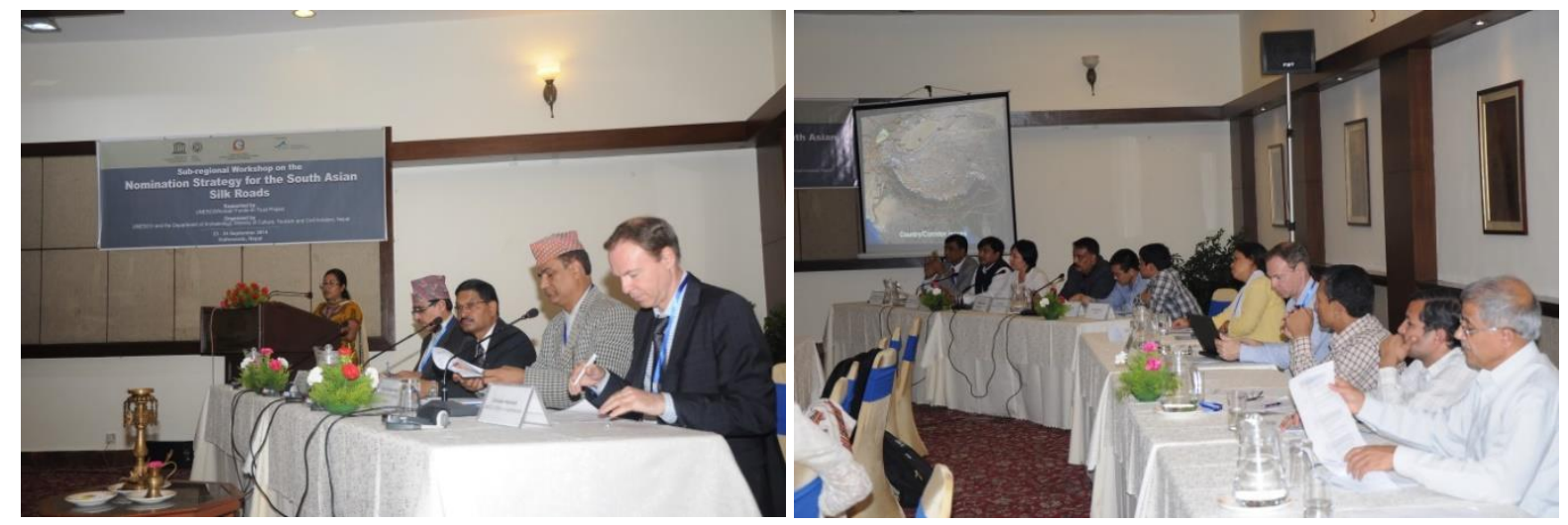

Figure 36. Kathmandu sub-regional workshop on the nomination strategy for the South Asian Silk Roads, September 2014 .

\subsubsection{Aims}

The main objectives of the workshop were to:

- $\quad$ review the present state of research on the Silk Roads in South Asia;

- $\quad$ review the actions already undertaken by the concerned State Parties;

- $\quad$ discuss the draft Serial and Transnational World Heritage Nomination Strategy for the South Asian Silk Road;

${ }^{17}$ See UNESCO Kathmandu office press releases: http://bit.ly/1pm5AOf, http://bit.ly/24xBjwd and http://bit.ly/1SdCXOx [Accessed February 2016]. 
- $\quad$ discuss the ways forward in selecting specific corridors and developing nomination dossiers, with an emphasis on trans-national working and co-operation;

- draft a plan of action; and

- $\quad$ develop action points for a possible transnational management coordination mechanism and harmonized documentation system.

\subsubsection{Participants}

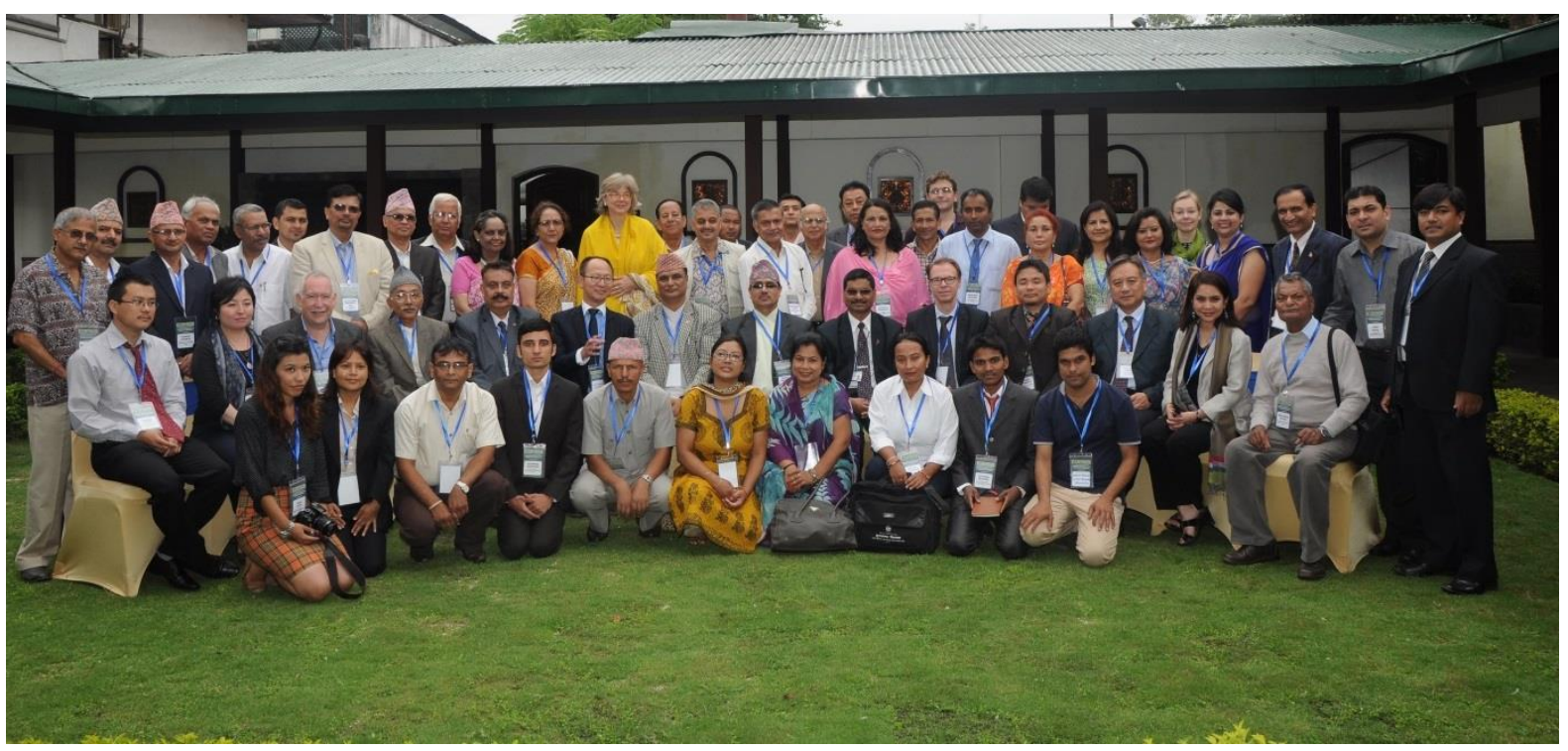

Figure 37. The participants at the Kathmandu sub-regional workshop on the nomination strategy for the South Asian Silk Roads, September 2014.

\begin{tabular}{|c|c|}
\hline Name & Designation \\
\hline \multicolumn{2}{|c|}{ Representatives from Bhutan } \\
\hline Mr Yeshi Samdrup & $\begin{array}{l}\text { Architect and focal person for World Heritage Sites Nomination, } \\
\text { Division for Conservation of Heritage Sites, Department of Culture, } \\
\text { Ministry of Home and Cultural Affairs, Royal Government of Bhutan }\end{array}$ \\
\hline Mr Karma Tenzin & $\begin{array}{l}\text { Architect and focal person for Archaeology Section, Division for } \\
\text { Conservation of Heritage Sites, Department of Culture, Ministry of } \\
\text { Home and Cultural Affairs, Royal Government of Bhutan }\end{array}$ \\
\hline \multicolumn{2}{|l|}{ Representatives from China } \\
\hline Prof Lyu (Lu) Zhou & $\begin{array}{l}\text { Professor, Tsinghua University Director of National Heritage Centre, } \\
\text { Tsinghua University and Vice-president of ICOMOS - China }\end{array}$ \\
\hline \multicolumn{2}{|c|}{ Representatives from India } \\
\hline Dr B.R. Mani & Additional Director General, Archaeological Survey of India \\
\hline Dr Shikha Jain & Member Secretary, Advisory Committee on World Heritage Matters \\
\hline \multicolumn{2}{|l|}{ Representatives from Nepal } \\
\hline Mr Bhesh Narayan Dahal & Director General, Department of Archaeology \\
\hline Mr Suresh Suras Shrestha & $\begin{array}{l}\text { Chief of Monument Conservation Section; Focal Point for Silk Roads } \\
\text { activities in Nepal; Chief Archaeological Officer, Department of } \\
\text { Archaeology }\end{array}$ \\
\hline Mr Sukra Sagar Shrestha & $\begin{array}{l}\text { National expert, Silk Roads activities in Nepal- Mustang corridor, } \\
\text { Kirtipur, Kathmandu }\end{array}$ \\
\hline
\end{tabular}


Delegates at opening session

Honourable Mr Deepak Minister of Culture, Tourism and Civil Aviation

Chandra Amatya

Mr Suresh Man Shrestha Secretary, Ministry of Culture, Tourism and Civil Aviation

Mr Bishwo Prakash Pandit Secretary-General, Nepal National Commission for UNESCO

Dr David James Molden Director General, International Centre for Integrated Mountain Development (ICIMOD)

National participants from Government Agencies

Mr Bharat Mani Subedi Joint Secretary, Culture Division, Ministry of Culture, Tourism and Civil Aviation

Mr Bharat Rawat Deputy Director General, Department of Archaeology

Mr Jaya Ram Shrestha $\quad$ Under Secretary, Culture Division, Ministry of Culture, Tourism and Civil Aviation

Jayanti Shrestha Archaeology Officer, Culture Division, Ministry of Culture, Tourism and Civil Aviation

Ms Saubhagya Chief Archaeological Officer and Chief of World Heritage Conservation

Pradhananga Section, Department of Archaeology

Mr Sampat Ghimire Senior Divisional Engineer, Department of Archaeology

Mr Upendra Kumar Khanal Chief Account Comptroller, Department of Archaeology

Mr Debendra Bhattarai $\quad$ Archaeological Officer, Focal Point for Cultural World Heritage Properties in Nepal, Department of Archaeology

Mr Laxman Raj Basukala $\quad$ Engineer, Department of Archaeology

Mr Ram Bahadur Kunwar Chief Archaeological Officer, Chief of Archaeology Section, Department of Archaeology

Mr Shyam Sundar Chief Archaeological Officer and Chief of Curio Section, Department of Rajbanshi Archaeology

Mr Min Kumar Sharma Chief Photographer, Department of Archaeology

Mr Mohan Singh Lama Archaeological Officer, World Heritage Conservation Section, Department of Archaeology

Ms Subhadra Bhattarai Archaeological Officer, Monument Conservation Section, Department

Mr Shova Maharjan $\quad$ Architect, World Heritage Conservation Section, Department of Archaeology

Mr Govinda Adhikari Sub-Engineer, Department of Archaeology

Mr Bhaskar Gyawali Antiquity and Pottery Officer, Archaeology Section, Department of

\begin{tabular}{ll} 
& Archaeology \\
\hline Mr Govinda Neupane & Technical Assistant, Department of Archaeology
\end{tabular}

Ms Saraswati Singh Chief Executive, Hanumandhoka Durbar Museum Development Committee, Hanumandhoka, Kathmandu

Mr Dhruba Adhikari Acting Chief, Monument Preservation and Palace Maintenance Office, Department of Archaeology Patan Durbar Square Monument Zone,Lalitpur

Ms Mangala Pradhan Chief, Monument Preservation and Palace Maintenance Office, Department of Archaeology, Bhaktapur Durbar Square Monument Zone, Bhaktapur 


\begin{tabular}{|c|c|}
\hline Ms Aruna Nakarmi & Chief, National Art Museum, Department of Archaeology, Bhaktapur \\
\hline Ms Mandakini Shrestha & $\begin{array}{l}\text { Chief, National Museum, Department of Archaeology, Chauuni, } \\
\text { Kathmandu }\end{array}$ \\
\hline Ms Sharada Shiwakoti & $\begin{array}{l}\text { Chief, National Numismatic Museum, Department of Archaeology, } \\
\text { Chaunni, Kathmandu }\end{array}$ \\
\hline Mr Kamal Prasad Regmi & $\begin{array}{l}\text { Chief, Central Laboratory, Department of Archaeology, Patan Durbar } \\
\text { Square Monument Zone, Lalitpur }\end{array}$ \\
\hline Mr Prakash Darnal & Chief, National Archives, Department of Archaeology \\
\hline Mr Fanindra Raj Kharel & $\begin{array}{l}\text { Deputy Director General, Department of National Parks and Wildlife } \\
\text { Conservation, Babarmahal, Kathmandu }\end{array}$ \\
\hline Mr Shyam Kumar Singh & Section Officer, Postal Services Department, Dillibazar, Kathmandu \\
\hline \multicolumn{2}{|c|}{ Former Officials of the Government of Nepal } \\
\hline Mr Sushil Ghimire & $\begin{array}{l}\text { Former Secretary of the Ministry of Culture, Tourism and Civil } \\
\text { Aviation, Kuleshwor, Kathmandu }\end{array}$ \\
\hline Ms Riddhi Baba Pradhan & $\begin{array}{l}\text { Former Secretary of the Ministry of Culture, Tourism and Civil } \\
\text { Aviation, Patan, Lalitpur }\end{array}$ \\
\hline Mr Bishnu Raj Karki & $\begin{array}{l}\text { Former Joint Secretary of the Ministry of Culture, Tourism and Civil } \\
\text { Aviation, Shantinagar, Kathmandu }\end{array}$ \\
\hline Mr Kosh Prasad Acharya & $\begin{array}{l}\text { Chief Executive, Pashupati Area Development Trust, Former Director } \\
\text { General of the Department of Archaeology, Gausala, Kathmandu }\end{array}$ \\
\hline $\begin{array}{l}\text { Mr Chandra Prasad } \\
\text { Tripathi }\end{array}$ & $\begin{array}{l}\text { Former Deputy Director General of the Department of Archaeology, } \\
\text { Sinamangal, Kathmandu }\end{array}$ \\
\hline Mr Tara Nanda Mishra & $\begin{array}{l}\text { Former Deputy Director General of the Department of Archaeology, } \\
\text { National expert on Silk Roads activities in Nepal }\end{array}$ \\
\hline Mr Bhim Prasad Nepal & $\begin{array}{l}\text { Former Chief of the National Archives of the Department of } \\
\text { Archaeology, Baneshwor, Kathmandu }\end{array}$ \\
\hline \multicolumn{2}{|c|}{ Other organizations/ institutions } \\
\hline Nawraj Pradhan & $\begin{array}{l}\text { Associate Coordinator Kailash Sacred Landscape Conservation and } \\
\text { Development Initiative, Ecosystem Management Analyst, Ecosystem } \\
\text { Services, International Centre for Integrated Mountain Development } \\
\text { (ICIMOD), Kathmandu }\end{array}$ \\
\hline Marjorie van Strien & $\begin{array}{l}\text { Tourism Specialist, International Centre for Integrated Mountain } \\
\text { Development (ICIMOD), Khumaltar, Lalitpur, Nepal }\end{array}$ \\
\hline Ms Dina Bangdel & $\begin{array}{l}\text { Associate Professor, Art History Program, Virginia Commonwealth } \\
\text { University, Qatar }\end{array}$ \\
\hline $\begin{array}{l}\text { Prof Susanne von der } \\
\text { Heide }\end{array}$ & Director, HimalAsia Foundation, Bishalnagar, Kathmandu \\
\hline Prof Dr Ramesh Dhungel & $\begin{array}{l}\text { Professor, Centre for Nepalese and Asian Studies (CNAS), Tribhuvan } \\
\text { University, Kirtipur, Kathmandu }\end{array}$ \\
\hline Dr Hari Shrestha & Former Reader, Tribhuvan University, Kirtipur, Kathmandu \\
\hline Prof Dr Jaga Man Gurung & Professor, Tribhuvan University, Kirtipur, Kathmandu \\
\hline Prof Dr Mukunda Raj Aryal & Professor, Tribhuvan University, Kirtipur, Kathmandu \\
\hline $\begin{array}{l}\text { Prof Dr Prem Kumar } \\
\text { Khatry }\end{array}$ & Professor, Tribhuvan University, Kirtipur, Kathmandu \\
\hline Prof Dr Peshal Dahal & Professor, Tribhuvan University, Kirtipur, Kathmandu \\
\hline $\begin{array}{l}\text { Prof Dr Dhan Bahadur } \\
\text { Kunwar }\end{array}$ & $\begin{array}{l}\text { Head, Central Department of Nepalese History, Culture and } \\
\text { Archaeology, Kirtipur, Kathmandu }\end{array}$ \\
\hline
\end{tabular}




\begin{tabular}{|c|c|}
\hline Prof Dr Beena Poudyal & $\begin{array}{l}\text { Professor, Central Department of Nepalese History, Culture and } \\
\text { Archaeology, Kirtipur, Kathmandu }\end{array}$ \\
\hline $\begin{array}{l}\text { Prof Sudarshan Raj Tiwari, } \\
\text { PhD }\end{array}$ & $\begin{array}{l}\text { Professor, Department of Architecture, Institute of Engineering, } \\
\text { Tribhuvan University, Pulchowk Campus, Pulchowk }\end{array}$ \\
\hline Mr Madan Rimal & $\begin{array}{l}\text { Associate Professor, Central Department of Nepalese History, Culture } \\
\text { and Archaeology, Kirtipur, Kathmandu }\end{array}$ \\
\hline Mr Pashupati Neupane & $\begin{array}{l}\text { Lecturer, Central Department of Nepalese History, Culture and } \\
\text { Archaeology, Kirtipur, Kathmandu }\end{array}$ \\
\hline Mr Shree Hari Thapa & $\begin{array}{l}\text { Lecturer, Thapathali Campus, Tribhuvan University, Thapathali, } \\
\text { Kathmandu }\end{array}$ \\
\hline Mr Kai Weise & $\begin{array}{l}\text { ICOMOS Nepal (Former mentor of Periodic Reporting)/ Heritage and } \\
\text { Management expert }\end{array}$ \\
\hline Mr Manindra Shrestha & ICOMOS Nepal, Architect \\
\hline \multicolumn{2}{|l|}{ District participants } \\
\hline Mr Basanta Bidari & Former Chief Archaeologist, Lumbini Development Trust \\
\hline Prof Chhatra Raj Shakya & Associate Professor, Palpa Multiple Campus \\
\hline Mr Indra Dhara Bista & $\begin{array}{l}\text { Social activist, Former Chairperson, Lomanthang Village Development } \\
\text { Committee (VDC), Chief, Conservation Area Management Committee, } \\
\text { Annapurna Conservation Area Project (ACAP), Mustang, Nepal }\end{array}$ \\
\hline Mr Gyachho Bista & Lomanthang, Mustang, Nepal \\
\hline Prof Dr Gitu Giri & Professor, Bhairahawa Multiple Campus, Bhairahawa \\
\hline Mr Ram Prasad Upadhyay & Chief, Dhaulagiri Multiple Campus, Baglung \\
\hline \multicolumn{2}{|l|}{ International participant } \\
\hline Mr Tim Williams & $\begin{array}{l}\text { ICOMOS International Expert for Silk Roads Thematic Studies, } \\
\text { University College London United Kingdom }\end{array}$ \\
\hline \multicolumn{2}{|l|}{ UNESCO } \\
\hline Mr Christian Manhart & UNESCO Representative to Nepal \\
\hline Dr Roland Lin & Asia and Pacific Unit, UNESCO World Heritage Centre, Paris \\
\hline Ms Nabha Basnyat- Thapa & Culture Unit, UNESCO Office in Kathmandu \\
\hline Ms Nipuna Shrestha & Culture Unit, UNESCO Office in Kathmandu \\
\hline Ms Neerana Shakya & IKM Unit, UNESCO Office in Kathmandu \\
\hline Ms Krija Hyoju & Intern, UNESCO Office in Kathmandu \\
\hline Ms Shreemanjari Tamrakar & Volunteer, UNESCO Office in Kathmandu \\
\hline \multicolumn{2}{|l|}{ Interpreter } \\
\hline Mr Anim Dahal & Interpreter, De-luxe Radio Service \\
\hline
\end{tabular}




\subsubsection{Programme}

Tuesday, 23 September 2014

\begin{tabular}{|c|c|}
\hline $9: 00-9: 30$ & Registration \\
\hline $9: 30-10: 30$ & Opening Session \\
\hline $9: 30-9: 35$ & Lighting the Sukunda by the Chief Guest \\
\hline \multirow[t]{2}{*}{$9: 35-9: 45$} & Welcome remarks and meeting objectives by \\
\hline & $\begin{array}{l}\text { Mr Christian Manhart } \\
\text { UNESCO Representative to Nepal }\end{array}$ \\
\hline \multirow[t]{2}{*}{$9: 45-9: 55$} & Welcome remarks by \\
\hline & $\begin{array}{l}\text { Mr Bhesh Narayan Dahal } \\
\text { Director General, Department of Archaeology, Nepal }\end{array}$ \\
\hline \multirow[t]{2}{*}{$9: 55-10: 05$} & Welcome remarks by \\
\hline & $\begin{array}{l}\text { H.E. Mr Choe Yong-jin } \\
\text { Ambassador of the Republic of Korea in Nepal }\end{array}$ \\
\hline \multirow[t]{2}{*}{ 10:05 - 10:15 } & Remarks by \\
\hline & $\begin{array}{l}\text { Mr Bishwo Prakash Pandit } \\
\text { Secretary-General, Nepal National Commission for UNESCO }\end{array}$ \\
\hline \multirow[t]{2}{*}{$10: 15-10: 25$} & Remarks by the Chief Guest \\
\hline & $\begin{array}{l}\text { Mr Suresh Man Shrestha } \\
\text { Secretary, Ministry of Culture, Tourism and Civil Aviation }\end{array}$ \\
\hline $10: 25-10: 30$ & Group photo \\
\hline $10: 30-10: 45$ & Coffee/tea break \\
\hline \multirow[t]{2}{*}{$10: 45-12: 30$} & Session I - Introduction \\
\hline & $\begin{array}{l}\text { Chairperson: Mr Bhesh Narayan Dahal, Director General, Department } \\
\text { of Archaeology, Nepal }\end{array}$ \\
\hline $10: 45-11: 00$ & Introduction of the participants \\
\hline \multirow[t]{2}{*}{ 11:00 - 11:30 } & $\begin{array}{l}\text { Presentation on the progress of the Serial and Transnational World } \\
\text { Heritage Nomination of the Silk Roads (consultation meetings, } \\
\text { adoption of the Concept Document, Coordination Committee } \\
\text { meetings) }\end{array}$ \\
\hline & $\begin{array}{l}\text { Dr Roland Lin } \\
\text { Asia and Pacific Unit, World Heritage Centre, UNESCO Paris }\end{array}$ \\
\hline \multirow[t]{2}{*}{ 11:30 - 12:00 } & Presentation of ICOMOS Silk Roads Thematic Study \\
\hline & $\begin{array}{l}\text { Tim Williams } \\
\text { ICOMOS International, University College London, United Kingdom }\end{array}$ \\
\hline $12: 00-12: 30$ & Discussion \\
\hline $12: 30-14: 00$ & Lunch break \\
\hline $14: 00-15: 45$ & $\begin{array}{l}\text { Session II - State Parties' presentations on review of national activities } \\
\text { related to the South Asian Silk Roads Serial and Transnational World } \\
\text { Heritage Nomination }\end{array}$ \\
\hline
\end{tabular}




\begin{tabular}{|c|c|}
\hline & $\begin{array}{l}\text { Chairperson: Mr Bishnu Raj Karki, Former Joint Secretary of Ministry } \\
\text { of Culture, Tourism and Civil Aviation }\end{array}$ \\
\hline \multirow[t]{3}{*}{$14: 00-14.45$} & Presentation of Nepal \\
\hline & $\begin{array}{l}\text { Mr Sukra Sagar Shrestha } \\
\text { Senior Archaeologist } \\
\text { National expert on Silk Roads activities in Nepal- Mustang corridor }\end{array}$ \\
\hline & $\begin{array}{l}\text { Mr Suresh Suras Shrestha } \\
\text { Chief Archaeological Officer } \\
\text { Focal Point for Silk Roads activities in Nepal } \\
\text { Department of Archaeology }\end{array}$ \\
\hline $14: 45-15: 00$ & Discussion \\
\hline \multirow{2}{*}{$15: 00-15: 30$} & Presentation of India \\
\hline & $\begin{array}{l}\text { Dr B R Mani } \\
\text { Additional Director General, Archaeology Survey of India }\end{array}$ \\
\hline $15: 30-15: 45$ & Discussion \\
\hline $15: 45-16: 00$ & Coffee/tea break \\
\hline \multirow[t]{2}{*}{$16: 00-17: 45$} & $\begin{array}{l}\text { Session II - State Parties' presentations on review of national activities } \\
\text { related to the South Asian Silk Roads Serial and Transnational World } \\
\text { Heritage Nomination (continued) }\end{array}$ \\
\hline & $\begin{array}{l}\text { Chairperson: Mr Bishnu Raj Karki, Former Joint Secretary of Ministry } \\
\text { of Culture, Tourism and Civil Aviation }\end{array}$ \\
\hline \multirow[t]{3}{*}{$16: 00-16.30$} & Presentation of Bhutan \\
\hline & $\begin{array}{l}\text { Mr Yeshi Samdrup } \\
\text { Architect and focal person for World Heritage Sites Nomination, } \\
\text { Division for Conservation of Heritage Sites, Department of Culture, } \\
\text { Ministry of Home and Cultural Affairs }\end{array}$ \\
\hline & $\begin{array}{l}\text { Mr Karma Tenzin } \\
\text { Architect and focal person for Archaeology Section, Division for } \\
\text { Conservation of Heritage Sites, Department of Culture, Ministry of } \\
\text { Home and Cultural Affairs }\end{array}$ \\
\hline $16: 30-16: 45$ & Discussion \\
\hline \multirow[t]{2}{*}{$16: 45-17: 30$} & Presentation of China \\
\hline & $\begin{array}{l}\text { Mr Lyu Zhou } \\
\text { Director, National Heritage Centre, Tsinghua University and Vice- } \\
\text { president of ICOMOS-China }\end{array}$ \\
\hline $17: 30-17: 45$ & Discussion \\
\hline
\end{tabular}

Wednesday, 24 September 2014

\begin{tabular}{ll}
\hline 9:00 - 10:30 & $\begin{array}{l}\text { Session III - Experience sharing: Transnational initiatives } \\
\text { Chairperson: Dr Shikha Jain, Member Secretary, Advisory Committee } \\
\text { on World Heritage Matters, India }\end{array}$ \\
\hline 9:00 - 9:30 & $\begin{array}{l}\text { Presentation of the experiences of the first inscribed Silk Roads "Silk } \\
\text { Roads: Initial Section of the Silk Roads, the Routes network of Tian- }\end{array}$
\end{tabular}




\begin{tabular}{|c|c|}
\hline & $\begin{array}{l}\text { shan Corridor," jointly prepared by China, Kazakhstan, and } \\
\text { Kyrgyzstan }\end{array}$ \\
\hline & $\begin{array}{l}\text { Tim Williams } \\
\text { ICOMOS International, University College London, United Kingdom }\end{array}$ \\
\hline $9: 30-9: 45$ & Discussion \\
\hline \multirow[t]{3}{*}{$9: 45-10: 15$} & $\begin{array}{l}\text { Presentation of the experiences in Documentation of Kailash Sacred } \\
\text { Landscape Conservation and Development Initiative }\end{array}$ \\
\hline & $\begin{array}{l}\text { Nawraj Pradhan } \\
\text { Associate Coordinator, Kailash Sacred Landscape Conservation and } \\
\text { Development Initiative and Ecosystem Management Analyst, } \\
\text { International Centre for Integrated Mountain Development (ICIMOD) }\end{array}$ \\
\hline & $\begin{array}{l}\text { Marjorie van Strien, Tourism Specialist } \\
\text { International Centre for Integrated Mountain Development } \\
\text { (ICIMOD) }\end{array}$ \\
\hline 10:15 - 10:30 & Discussion \\
\hline $10: 30-10: 45$ & Coffee/tea break \\
\hline \multirow[t]{2}{*}{$10: 45-11: 30$} & Session IV - Experience sharing: Research work \\
\hline & $\begin{array}{l}\text { Chairperson: Mr Yeshi Samdrup, Division for Conservation of } \\
\text { Heritage Sites, Department of Culture, Ministry of Home and Cultural } \\
\text { Affairs, Bhutan }\end{array}$ \\
\hline \multirow[t]{2}{*}{$10: 45-11: 00$} & $\begin{array}{l}\text { Presentation on the cultural transfers on the ancient trade route } \\
\text { through Mustang linking the Silk Road with the Gangetic Plains - new } \\
\text { aspects }\end{array}$ \\
\hline & $\begin{array}{l}\text { Prof Susanne von der Heide } \\
\text { HimalAsia Foundation }\end{array}$ \\
\hline \multirow[t]{2}{*}{ 11:00 - 11:15 } & $\begin{array}{l}\text { Presentation on the Historical and Culture Significance of Nepal's } \\
\text { "Heritage-Corridor" in the South Asian Silk Roads }\end{array}$ \\
\hline & $\begin{array}{l}\text { Ms Dina Bangdel, PhD } \\
\text { Associate Professor and Director, Art History Program, Virginia } \\
\text { Commonwealth University, Qatar }\end{array}$ \\
\hline $11: 15-11: 30$ & Discussion \\
\hline \multirow[t]{2}{*}{$11: 30-12: 30$} & $\begin{array}{l}\text { Session IV - The way forward: Nomination Strategy for the South } \\
\text { Asian Silk Roads and Action Plan }\end{array}$ \\
\hline & Chairperson: Representative, China \\
\hline \multirow[t]{2}{*}{$11: 30-12: 00$} & $\begin{array}{l}\text { Presentation on draft Serial and Transnational World Heritage } \\
\text { Nomination Strategy for the South Asian Silk Roads and developing of } \\
\text { a possible transnational management coordination mechanism and } \\
\text { harmonized documentation system }\end{array}$ \\
\hline & $\begin{array}{l}\text { Tim Williams } \\
\text { ICOMOS International, University College London, United Kingdom }\end{array}$ \\
\hline $12: 00-12: 30$ & Discussion \\
\hline $12: 30-14: 00$ & Lunch break \\
\hline
\end{tabular}




\begin{tabular}{|c|c|}
\hline $14: 00-15: 00$ & $\begin{array}{l}\text { Session IV - The way forward: Nomination Strategy for the South } \\
\text { Asian Silk Roads and Action Plan (continued) } \\
\text { Chairperson: Moe Chiba, Programme Specialist for Culture, UNESCO } \\
\text { New Delhi Office }\end{array}$ \\
\hline $14: 00-14: 30$ & $\begin{array}{l}\text { Floor discussion on finalization of Serial and Transnational World } \\
\text { Heritage Nomination Strategy for the South Asian Silk Roads } \\
\text { Representatives } \\
\text { State parties of Bhutan, China, India and Nepal }\end{array}$ \\
\hline $14: 30-15: 00$ & $\begin{array}{l}\text { Adoption of Serial and Transnational World Heritage Nomination } \\
\text { Strategy for the South Asian Silk Roads } \\
\text { Representatives } \\
\text { State parties of Bhutan, China, India and Nepal }\end{array}$ \\
\hline 15:00 - 15:15 & Coffee/tea break \\
\hline $15: 15-17: 30$ & $\begin{array}{l}\text { Session IV - Nomination Strategy for the South Asian Silk Roads and } \\
\text { Action Plan (continued) } \\
\text { Chairperson: Mr Christian Manhart, UNESCO Representative to } \\
\text { Nepal }\end{array}$ \\
\hline $15: 15-15: 45$ & $\begin{array}{l}\text { Goal orientation for the way forward } \\
\text { Tim Williams } \\
\text { ICOMOS International, University College London, United Kingdom }\end{array}$ \\
\hline $\begin{array}{l}15: 45-16: 30 \\
16: 30-17: 00\end{array}$ & $\begin{array}{l}\text { Discussion about the diverse issues and needs } \\
\text { Drafting Action Plan } \\
\text { Representatives } \\
\text { State parties of Bhutan, China, India and Nepal }\end{array}$ \\
\hline $17: 00-17: 30$ & $\begin{array}{l}\text { Approval of the Action Plan } \\
\text { Representatives } \\
\text { State parties of Bhutan, China, India and Nepal }\end{array}$ \\
\hline $17: 30-18: 00$ & $\begin{array}{l}\text { Closing Session } \\
\text { Chairperson: Dr Roland Lin, Asia and Pacific Unit, World Heritage } \\
\text { Centre, UNESCO Paris }\end{array}$ \\
\hline $17: 30-17: 40$ & $\begin{array}{l}\text { Closing remarks } \\
\text { Mr Bhesh Narayan Dahal } \\
\text { Director General, Department of Archaeology of Nepal }\end{array}$ \\
\hline $17: 40-17: 50$ & $\begin{array}{l}\text { Closing remarks } \\
\text { Mr Suresh Man Shrestha } \\
\text { Secretary, Ministry of Culture, Tourism and Civil Aviation of Nepal }\end{array}$ \\
\hline $17: 50-18: 00$ & $\begin{array}{l}\text { Vote of thanks } \\
\text { Mr Christian Manhart } \\
\text { UNESCO Representative to Nepal }\end{array}$ \\
\hline
\end{tabular}




\subsubsection{Outcomes}

During the two-day workshop, each participating country presented a review of national activities related to the South Asian Silk Roads Serial and Transnational World Heritage Nomination. The background to the UNESCO Serial and Transnational World Heritage Nomination of the Silk Roads was presented by Prof Roland Lin, followed by the ICOMOS Silk Roads Thematic Study, presented by Tim Williams.

Very useful presentations on Nepal's ideas for their corridor selection, by Mr Sukra Sagar Shrestha and Mr Suresh Suras Shrestha, and subsequent presentations by Prof Susanne von der Heide and Ms Dina Bangdel, provided the basis for an extended discussion of the merits of the various routes in Nepal and their priority/practicality for nomination. Discussions focused on the quality of information currently available, the sensitives of local issues (for example in Mustang) and the quality of the resource.

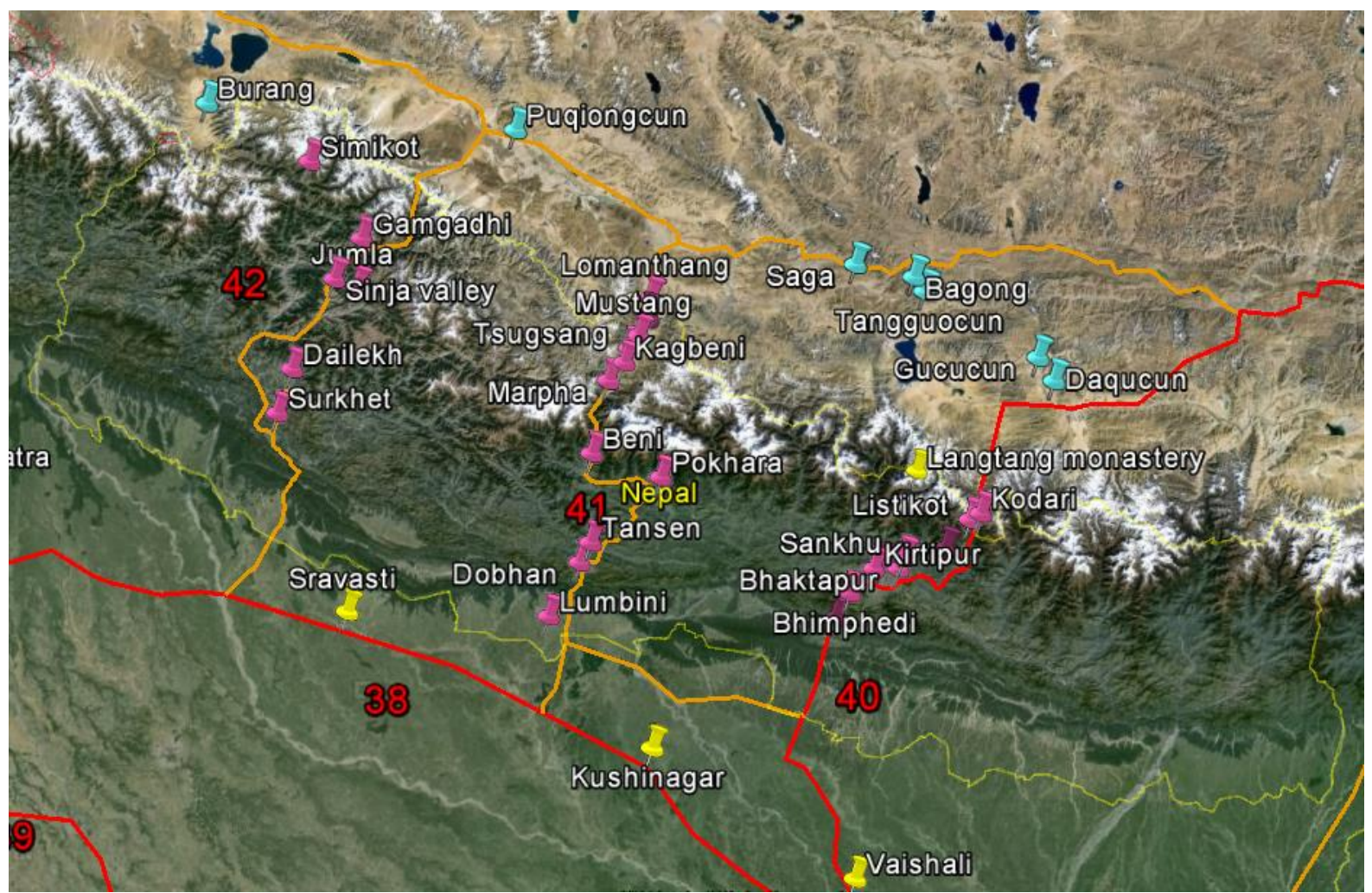

Figure 38. Routes through Nepal based on the comments of Mr Sukra Sagar Shrestha. Base map: () Google. Image Landsat. Data SIO, NOAA, U.S. Navy, NGA, GEBCO. US Dept of State Geographer
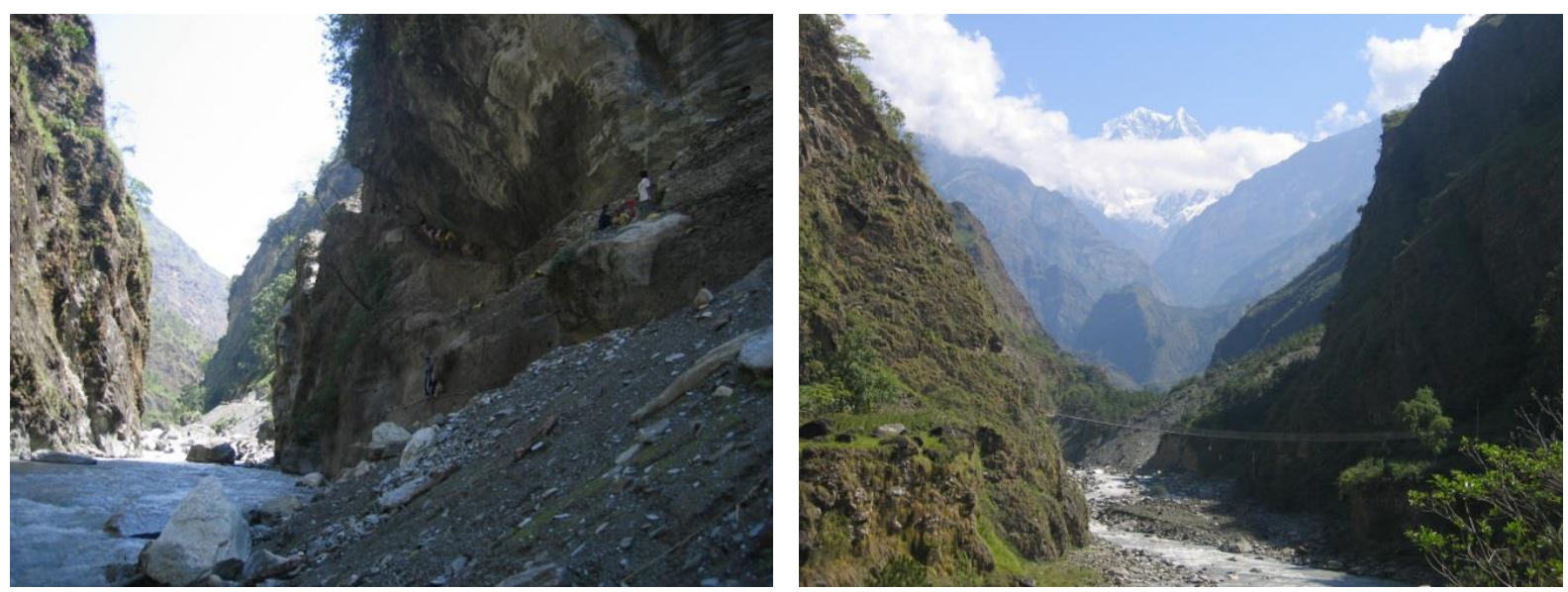

Figure 39. The Kaligandaki Gorge: an example of the remote and rigged terrain of the mountain routes (Photographs Mr Sukra Sagar Shrestha). 


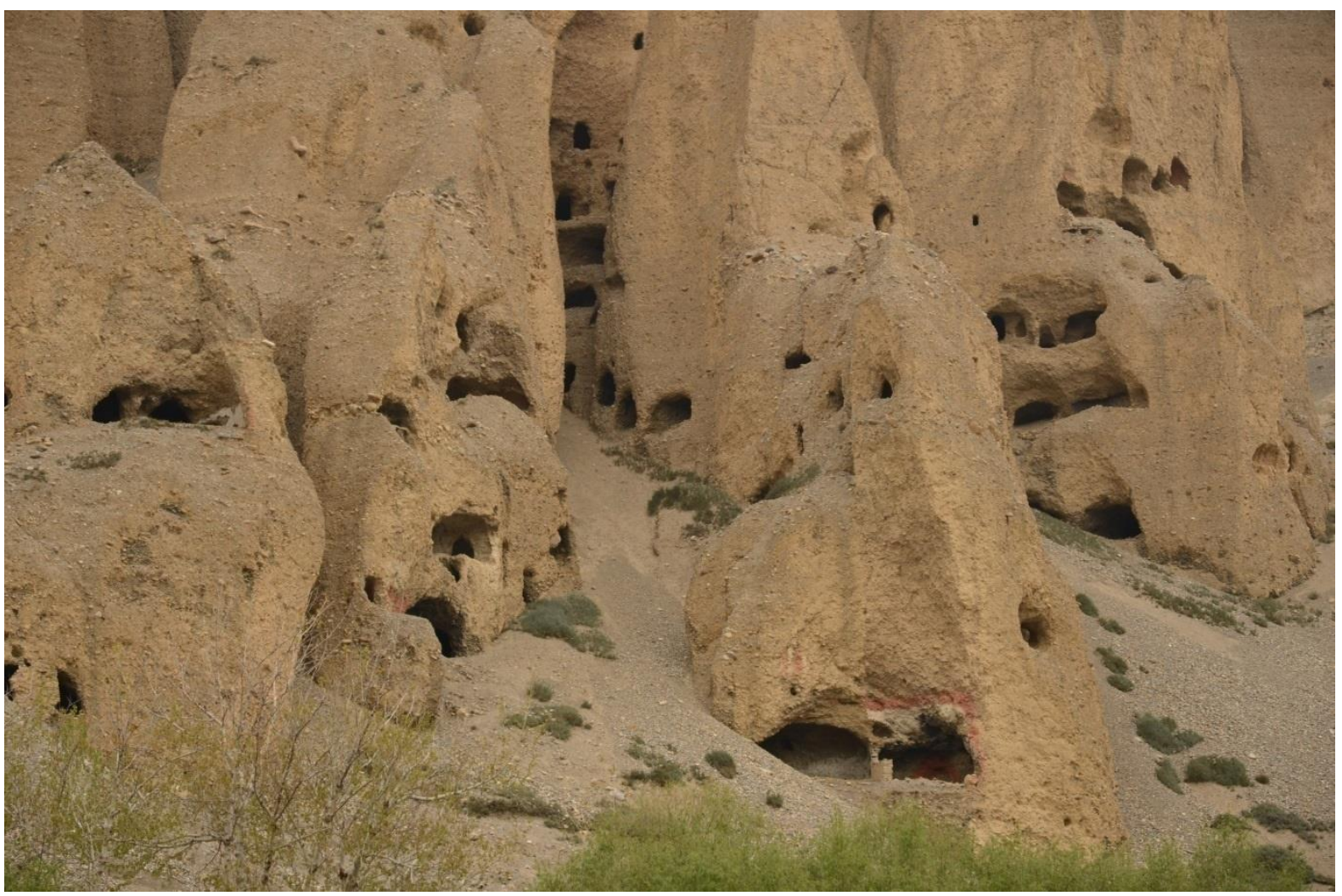

Figure 4o. Caves in Mustang (photograph Prof Susanne von der Heide).

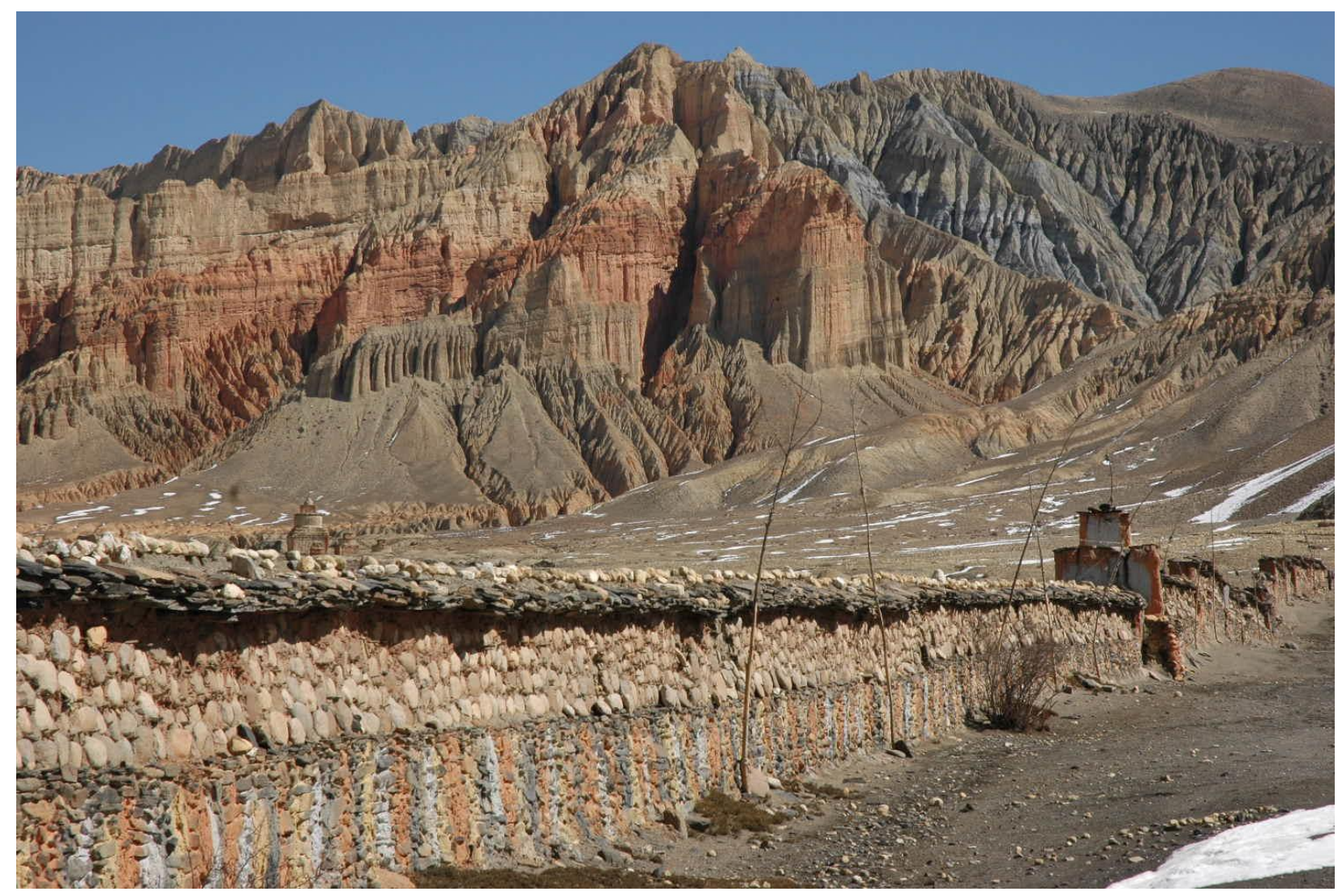

Figure 41. Ghemi, an outstanding example of the long walls organizing and controlling this landscape (Photograph Mr Sukra Sagar Shrestha). 
Presentations were also given by the representatives: from India, Dr Mani offered an extremely useful discussion on the issues from an Indian perspective, and both China and Bhutan commented on current thinking and approaches, but both also recognised that considerable further research would be needed to identify sites and understand selection within the region. These discussions are reflected in the final South Asian Silk Roads: Serial and Transnational World Heritage Nomination Strategy (see below).

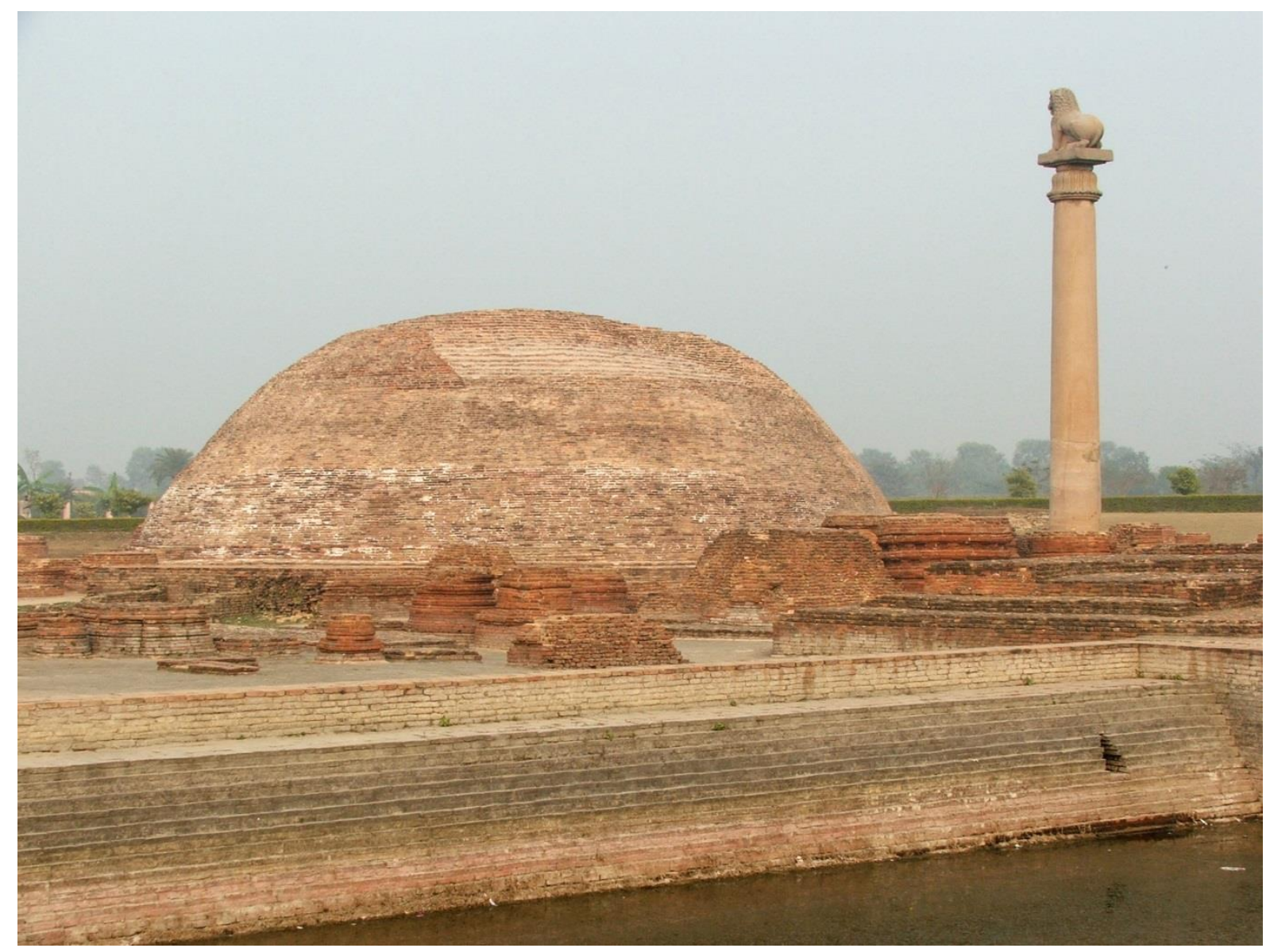

Figure 42. Stupa with Asokan pillar, at Vaishali, Bihar, India (Creative Commons Attribution-Share Alike 2.5).

A very useful presentation of the experiences in the documentation of Kailash Sacred Landscape, by Nawraj Pradhan and Marjorie van Strien, from the International Centre for Integrated Mountain Development (ICIMOD), highlighted some key issues in trans-boundary working and the need for integrated communication and documentation.

One of the main focuses of the meeting was the presentation of the draft South Asian Silk Roads: Serial and Transnational World Heritage Nomination strategy by Tim Williams. This was followed by a very extensive discussion of approaches, selection processes and future action. This sub-regional workshop was an excellent opportunity to understand the region's rich historical and cultural significance. 


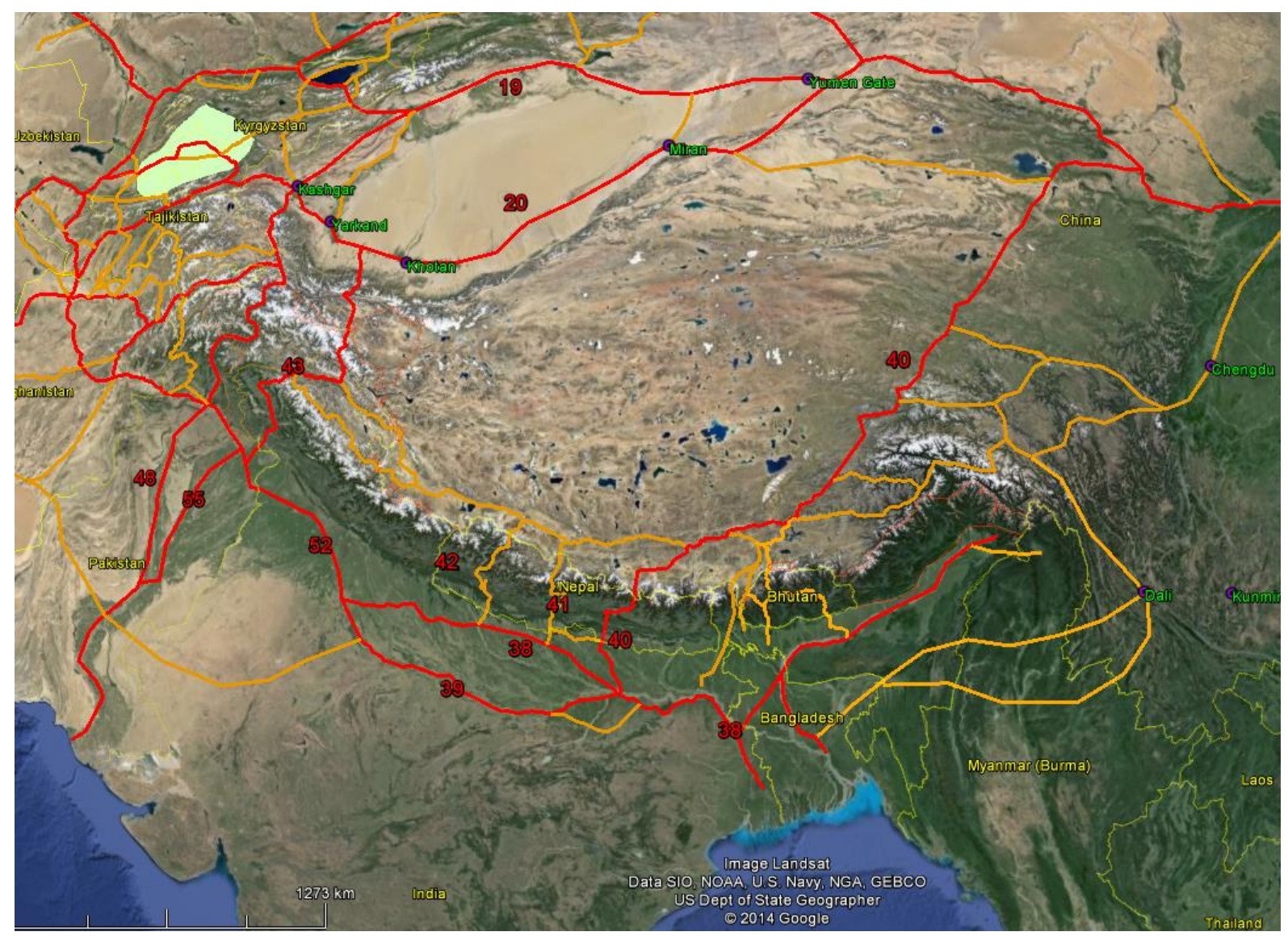

Figure 43. The South Asian region with some of the main corridors under discussion during the workshop.

The meeting was very constructive. It led to an agreed a South Asian Silk Roads: Serial and Transnational World Heritage Nomination Strategy (see Appendix 1) and a draft Action Plan (see Appendix 3), which was followed up by Recommendations for the South Asian Silk Roads (2014) (see Appendix 2), which summarised the agreed actions. 


\subsection{Almaty, Kazakhstan: 23-27 November 2015, 4th meeting of the Coordinating Committee of the Serial World Heritage Nomination of the Silk Roads}

\subsubsection{Introduction}

The UNESCO World Heritage Centre and the UNESCO Cluster Office in Almaty, in cooperation with the Kazakhstan National Commission for UNESCO, organized the 4th Meeting of the Coordinating Committee of the Serial World Heritage Nomination of the Silk Roads, from 23 to 27 November 2015 in Almaty, Kazakhstan. The 4th Coordinating Committee brought together national focal points and experts from the twelve country members of the Silk Roads Coordination Committee: Afghanistan, China, India, Iran, Japan, Kazakhstan, Korea, Kyrgyzstan, Nepal, Tajikistan, Turkmenistan, and Uzbekistan and other partner countries (Azerbaijan, Bhutan, and Pakistan). The delegations from each State Party was composed of two representatives; one an official possessing the necessary authority to approve the strategy for serial nomination, and one expert with a background in history, archaeology, and/or heritage of the Silk Roads, or on conservation of cultural properties.

The meeting reviewed progress on the Silk Road World Heritage Nominations process, including the South Asian Silk Roads, the Silk Roads Syr Darya Heritage Corridor, and other initiatives such as the Maritime Silk Roads. It also considered the potential need for further development of the ICOMOS Silk Roads Thematic Study, covering Eastern and Western Asia.

As mentioned above, the problems resulting from the natural disasters encountered in Nepal, it was difficult to undertake the cross-country consultation in South Asia. So UNESCO took the opportunity of the presence of the four related States Parties (China, India, Nepal and Bhutan) in meeting to explore the establishment of a South Asian Silk Roads Steering Committee and Working Group, for the first South Asian priority transnational Silk Roads heritage corridor(s).

\subsubsection{Participants}

\begin{tabular}{|l|l|}
\hline OFFICIAL REPRESENTATIVES OF STATE-PARTIES \\
\hline NAWABI Fazil Ahad & $\begin{array}{l}\text { Ministry of Culture and Information, Islamic Republic of } \\
\text { Afghanistan }\end{array}$ \\
\hline DORJI Wangchuk & $\begin{array}{l}\text { Ministry of Culture and Information, Islamic Republic of } \\
\text { Afghanistan }\end{array}$ \\
\hline YESHI Samdrup & $\begin{array}{l}\text { Department of Culture, Ministry of Home and Cultural Affairs, } \\
\text { Kingdom of Bhutan }\end{array}$ \\
\hline YU XIAOPING & $\begin{array}{l}\text { Department of Culture, Ministry of Home and Cultural Affairs, } \\
\text { Kingdom of Bhutan }\end{array}$ \\
\hline AHMADIROINI Seyed Vahid & $\begin{array}{l}\text { Chief of Education Section, National Commission for UNESCO, } \\
\text { People's Republic of China }\end{array}$ \\
\hline $\begin{array}{l}\text { Head of Silk Road Research Centre ICHHTO, Islamic Republic of } \\
\text { Iran }\end{array}$ \\
\hline Moldakhmetovich & $\begin{array}{l}\text { Head of the National Committee on World Heritage, Republic of } \\
\text { Kazakhstan }\end{array}$ \\
\hline KUYMAKBAYEV Kanat & "Kazrestavracia" RSE, Republic of Kazakhstan \\
\hline DUISHANALIEVA Aisin & Ministry of culture, information and tourism, Kyrgyz Republic \\
\hline AMANBAEVA Bakyt & $\begin{array}{l}\text { Leading research fellow, National Academy of Sciences, Kyrgyz } \\
\text { Republic }\end{array}$ \\
\hline GAUTAM Damodar & $\begin{array}{l}\text { Chief Archaeological Officer, Department of Archaeology, Ministry } \\
\text { of Culture, Tourism and Civil Aviation, Nepal }\end{array}$ \\
\hline SHRESTHA Suresh Suras & Chief Archaeological Officer, Department of Archaeology, Ministry \\
\hline
\end{tabular}




\begin{tabular}{|c|c|}
\hline & of Culture, Tourism and Civil Aviation, Nepal \\
\hline $\begin{array}{l}\text { MIRZA Nasir-Un-Din } \\
\text { Mashhood Ahmad }\end{array}$ & $\begin{array}{l}\text { Joint Secretary (Heritage), Ministry of Information, Broadcasting } \\
\text { and National Heritage, Islamic Republic of Pakistan }\end{array}$ \\
\hline AFZAL Muhammad & $\begin{array}{l}\text { Assistant Director, Ministry of Information, Broadcasting and } \\
\text { National Heritage, Islamic Republic of Pakistan }\end{array}$ \\
\hline MUN Gyeonggyu & $\begin{array}{l}\text { International Cooperation Division, Cultural Heritage } \\
\text { Administration, Republic of Korea }\end{array}$ \\
\hline KANG In Uk & Professor of Kyunghee University, Republic of Korea \\
\hline KHODZHAEV Sherali & $\begin{array}{l}\text { Head of Department of Protection and Use of Historical and } \\
\text { Cultural Heritage, Ministry of Culture, Republic of Tajikistan }\end{array}$ \\
\hline AKRAMOV Zakiryo & $\begin{array}{l}\text { Director of the A. Donish Institute of history, archaeology and } \\
\text { ethnography, Academy of sciences, Republic of Tajikistan }\end{array}$ \\
\hline ÖZOEMIR Umut & $\begin{array}{l}\text { General Directorate of Cultural Heritage and Museums, Ministry of } \\
\text { Culture and Tourism, Republic of Turkey }\end{array}$ \\
\hline AKTÜRE Zeynep & $\begin{array}{l}\text { Tangible Heritage Committee, National Commission for UNESCO, } \\
\text { Republic of Turkey }\end{array}$ \\
\hline POLADOV Kuvandyk & $\begin{array}{l}\text { Secretary general of the National Commission for UNESCO, } \\
\text { Turkmenistan }\end{array}$ \\
\hline MAMEDOV Muhametdurdy & $\begin{array}{l}\text { Head of the National Administration for Protection, Research and } \\
\text { Restoration of Historical and Cultural Monuments, Turkmenistan }\end{array}$ \\
\hline RAKHMANOV Abdisafikhan & $\begin{array}{l}\text { Deputy Head of the 'Principal Department for Protection and } \\
\text { Utilization of Objects of Cultural Heritage, Ministry of Culture and } \\
\text { Sports, Republic of Uzbekistan }\end{array}$ \\
\hline MATBABAEV Bokijon & $\begin{array}{l}\text { Institute of Archaeology in Samarkand, Academy of Sciences, } \\
\text { Republic of Uzbekistan }\end{array}$ \\
\hline KAMOHARA Masayoshi & $\begin{array}{l}\text { Extraordinary and Plenipotentiary Ambassador of Japan, in } \\
\text { Kazakhstan }\end{array}$ \\
\hline \multicolumn{2}{|l|}{ UNESCO } \\
\hline JING Feng & Chief, Asia and the Pacific Unit, UNESCO World Heritage Centre \\
\hline LIN Chih-H & $\begin{array}{l}\text { Project Officer, Asia and the Pacific Unit, UNESCO World Heritage } \\
\text { Centre }\end{array}$ \\
\hline LAZAREV Sergey & Director of UNESCO Almaty Cluster Office \\
\hline PESHKOV Yuri & Culture Specialist of UNESCO Almaty Cluster Office \\
\hline ALLAYAROV Sanjarbek & Culture Specialist of UNESCO Tashkent Office \\
\hline ZHANSEITOVA Aigerim & Culture Assistant of UNESCO Almaty Cluster Office \\
\hline \multicolumn{2}{|c|}{ REPRESENTATIVES OF KAZAKHSTAN STATE ADMINISTRATIONS } \\
\hline MUHAMEDIULY Arystanbek & Minister of Culture and Sports of the Republic of Kazakhstan \\
\hline $\begin{array}{l}\text { BAIBEK Bauyrzhan } \\
\text { Kydyrgaliuly }\end{array}$ & Mayor of the Almaty City of the Republic of Kazakhstan \\
\hline $\begin{array}{l}\text { UTEOBNOVA Assel } \\
\text { Brkenovna }\end{array}$ & $\begin{array}{l}\text { Secretary-General of the National Commission of the Republic of } \\
\text { Kazakhstan for UNESCO and ISESCO }\end{array}$ \\
\hline $\begin{array}{l}\text { AUEZOV Erbulat } \\
\text { Kudryanovich }\end{array}$ & $\begin{array}{l}\text { Deputy Director of the Department of Culture of the Local } \\
\text { Administration of the Almaty City }\end{array}$ \\
\hline $\begin{array}{l}\text { ESDAULETOV Rakhmet } \\
\text { Razbekovich }\end{array}$ & $\begin{array}{l}\text { Head of Department of culture, archives and documentation, Local } \\
\text { Administration of the Almaty Region of the Republic of } \\
\text { Kazakhstan }\end{array}$ \\
\hline $\begin{array}{l}\text { ARENOVA Gulnar } \\
\text { Samatovna }\end{array}$ & $\begin{array}{l}\text { Director of Almaty Regional Historical Museum, Local } \\
\text { Administration of the South Kazakhstan Region of the Republic of } \\
\text { Kazakhstan }\end{array}$ \\
\hline $\begin{array}{l}\text { DUYSENBAYEVA Gulzhanat } \\
\text { Ibrakhimkyzy }\end{array}$ & $\begin{array}{l}\text { Director of Historical-Cultural-Ethnographical Centre, Local } \\
\text { Administration of the South Kazakhstan Region of the Republic of } \\
\text { Kazakhstan }\end{array}$ \\
\hline MUSAGULOVA Ayzat & $\begin{array}{l}\text { Department of culture, archives and documentation, Local } \\
\text { Administration of the Kyzylorda Region of the Republic of } \\
\text { Kazakhstan }\end{array}$ \\
\hline ORAZIMAN Akmaral & $\begin{array}{l}\text { National Commission of the Republic of Kazakhstan for UNESCO } \\
\text { and ISESCO }\end{array}$ \\
\hline ALZHANOV Baurzhan & National Commission of the Republic of Kazakhstan for UNESCO \\
\hline
\end{tabular}




\begin{tabular}{|c|c|}
\hline & and ISESCO \\
\hline KENZHINA Anel & $\begin{array}{l}\text { National Commission of the Republic of Kazakhstan for UNESCO } \\
\text { and ISESCO }\end{array}$ \\
\hline \multicolumn{2}{|l|}{ INTERNATIONAL EXPERTS } \\
\hline FENG Jian & $\begin{array}{l}\text { Deputy Director, ICOMOS International Conservation Center- } \\
\text { Xi'an }\end{array}$ \\
\hline LI Erwu & $\begin{array}{l}\text { Head of Information Center, ICOMOS International Conservation } \\
\text { Center-Xi'an }\end{array}$ \\
\hline ZHOU Xiaochen & Staff, ICOMOS International Conservation Center-Xi'an \\
\hline CHEN LING & $\begin{array}{l}\text { China Working Group of the Silk Roads: Routes Network of } \\
\text { Chang'an-Tianshan Corridor, Professor of Peking University }\end{array}$ \\
\hline WILLIAMS Tim & Senior Lecturer, UCL Institute of Archaeology, ICOMOS Expert \\
\hline YAMAUCHI Kazuya & $\begin{array}{l}\text { Head of Regional Environment Section, Japan Center for } \\
\text { International Cooperation in Conservation National Research } \\
\text { Institute for Cultural Properties }\end{array}$ \\
\hline VOYAKIN Dmitriy & UNESCO Regional facilitator \\
\hline JORAYEV Gai & UCL Institute of Archaeology \\
\hline VILEIKIS Ona & University of Leuven \\
\hline LU QIONG & ICOMOS China, Member of ICOMOS Executive Committee \\
\hline \multicolumn{2}{|l|}{ KAZAKH EXPERTS } \\
\hline $\begin{array}{l}\text { BAYTANAEV Baurzhan } \\
\text { Abishevich }\end{array}$ & $\begin{array}{l}\text { Director-General of the Institute of Archaeology named after A. } \\
\text { Kh. Margulan RSBE of the Ministry of Education and Sciences of } \\
\text { the Republic of Kazakhstan }\end{array}$ \\
\hline $\begin{array}{l}\text { KARYMSAKOV Arnur } \\
\text { Zhasabekovich }\end{array}$ & Director of the "Kazrestavracia" RSE \\
\hline $\begin{array}{l}\text { TUREKULOVA Natalia } \\
\text { Viktorovna }\end{array}$ & President of ICOMOS-Kazakhstan \\
\hline USTEMIROV Kairat & $\begin{array}{l}\text { National Committee of the Republic of Kazakhstan on World } \\
\text { Heritage }\end{array}$ \\
\hline $\begin{array}{l}\text { TOKMAGAMBETOV } \\
\text { Erkebulat }\end{array}$ & $\begin{array}{l}\text { National Committee of the Republic of Kazakhstan on World } \\
\text { Heritage }\end{array}$ \\
\hline TAIMAGAMBETOV Zhaken & $\begin{array}{l}\text { National Committee of the Republic of Kazakhstan on World } \\
\text { Heritage }\end{array}$ \\
\hline SKLYARENKO Sergey & $\begin{array}{l}\text { National Committee of the Republic of Kazakhstan on World } \\
\text { Heritage }\end{array}$ \\
\hline SAMASHEV Zeinolla & $\begin{array}{l}\text { National Committee of the Republic of Kazakhstan on World } \\
\text { Heritage }\end{array}$ \\
\hline MUKHTAROVA Gulmira & $\begin{array}{l}\text { National Committee of the Republic of Kazakhstan on World } \\
\text { Heritage }\end{array}$ \\
\hline $\begin{array}{l}\text { MOLDABERGENOVA } \\
\text { Zhanat }\end{array}$ & $\begin{array}{l}\text { National Committee of the Republic of Kazakhstan on World } \\
\text { Heritage }\end{array}$ \\
\hline DVBROVSKAYA Lyudmila & $\begin{array}{l}\text { National Committee of the Republic of Kazakhstan on World } \\
\text { Heritage }\end{array}$ \\
\hline BEKTUREEVA Roza & $\begin{array}{l}\text { National Committee of the Republic of Kazakhstan on World } \\
\text { Heritage }\end{array}$ \\
\hline AKYLBEK Serik & $\begin{array}{l}\text { National Committee of the Republic of Kazakhstan on World } \\
\text { Heritage }\end{array}$ \\
\hline AGITAEV Saduakas & $\begin{array}{l}\text { National Committee of the Republic of Kazakhstan on World } \\
\text { Heritage }\end{array}$ \\
\hline KAMALOVA Gulnara & "Kazrestavracia" RSE \\
\hline GRIGORIEV Fedor & "Kazrestavracia" RSE \\
\hline DZHALDASOVA Saule & "Kazrestavracia" RSE \\
\hline BEYSEMBAEVA Lyazzat & "Kazrestavracia" RSE \\
\hline EMELINA Irina & "Kazrestavracia" RSE \\
\hline ELEUOV Madiyar & Al-Farabi Kazakh National University \\
\hline YASHENKO Roman & Al-Farabi Kazakh National University \\
\hline MALTSEVA Elina & Delegate on World Heritage Young Expert Forum, Bonn, Germany \\
\hline ILIIN Roman & Institute of Archaeology named after A. Kh. Margulan, RSBE of the \\
\hline
\end{tabular}




\begin{tabular}{|ll|}
\hline KAMALDINOV Iliyar & Ministry of Education and Sciences of the Republic of Kazakhstan \\
\hline SAVELIEVA Tamara & $\begin{array}{l}\text { Institute of Archaeology named after A. Kh. Margulan, RSBE of the } \\
\text { Ministry of Education and Sciences of the Republic of Kazakhstan }\end{array}$ \\
\hline GORYACHEV Aleksandr & $\begin{array}{l}\text { Institute of Archaeology named after A. Kh. Margulan, RSBE of the } \\
\text { Ministry of Education and Sciences of the Republic of Kazakhstan }\end{array}$ \\
\hline Anstitute of Archaeology named after A. Kh. Margulan, RSBE of the \\
Ministry of Education and Sciences of the Republic of Kazakhstan \\
\hline SOROKIN Denis & "Archaeological Expertise" LLC \\
\hline KHABIBULAYEV Farukh & "Archaeological Expertise" LLC \\
\hline GURULEV Mikhail & "Archaeological Expertise" LLC \\
\hline ZHELEZNYAKOV Boris & RSE Museum-reserve "Tanbaly" \\
\hline ROGOZHINSKIY Aleksey & Specialist on petroglyph art \\
\hline EROFEEVA Irina & $\begin{array}{l}\text { Institute of Culture of the Ministry of Culture and Sports of the } \\
\text { Republic of Kazakhstan }\end{array}$ \\
\hline ABAZOV Rafis & Visiting professor, Director of model UN-New Silk Way project \\
\hline SYDYKOV Aybek & Director of the museum of the Almaty City \\
\hline FAIZULLINA Galia & Research fellow of the museum of the Almaty City \\
\hline YESSENOVA Khanzada & $\begin{array}{l}\text { Acting Chair of the National Committee on ICH Safeguarding to } \\
\text { the National Commission for UNESCO and ISESCO in the } \\
\text { Republic of Kazakhstan }\end{array}$ \\
\hline MASSANOV Madjer & Organization committee \\
\hline BAIPAKOV Marat & Organization committee \\
\hline PIMENOVA Anna & Organization committee \\
\hline ISKALIYEVA Malika & Organization committee \\
\hline VOYAKINA Natalia & Organization committee \\
\hline TOLEUTAYEVA Shyryn & Organization committee \\
\hline KEUTAYEVA Altynai & Organization committee \\
\hline
\end{tabular}

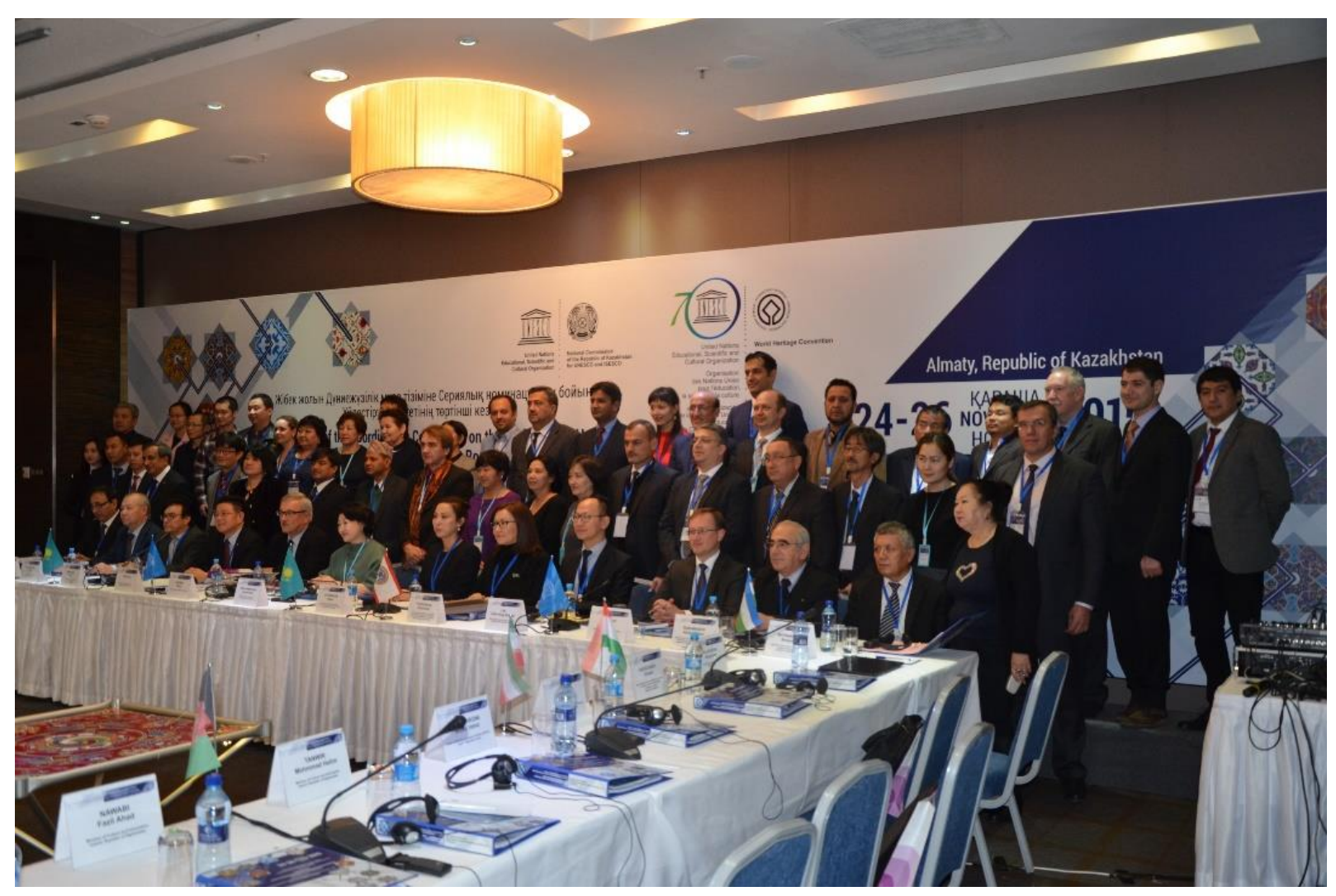

Figure 44. The participants at the 4th meeting of the Coordinating Committee of the Serial World Heritage Nomination of the Silk Roads, in Almaty, Kazakhstan: 23-27 November 2015. 


\subsubsection{Activities}

After a presentation by Tim Williams on the South Asian Nomination strategy there was a discussion group, within the context of the wider Silk Roads meeting, which explored progress on the South Asian Silk Roads. It was attended by representatives of Bhutan (Wangchuk Dorji and Samdrup Yeshi), China (Erwu Li and Xiaochen Zhou from IICC Xi'an; Chen Ling, Professor of Peking University; and Lu Qiong, ICOMOS China), Nepal (Damodar Gautam and Suresh Suras Shrestha from the Department of Archaeology, Ministry of Culture, Tourism and Civil Aviation) and Pakistan (Nasir-Un-Din Mashhood Ahmad Mirza and Muhammad Afzal, from the Ministry of Information, Broadcasting and National Heritage); with observers from Republic of Korea (Gyeonggyu Mun, from the Cultural Heritage Administration; and In Uk Kang, Professor of Kyunghee University) and the Islamic Republic of Iran (Seyed Vahid Ahmadiroini, ICHHTO); along with Tim Williams (UCL \& ICOMOS) and Roland Lin (UNESCO/WHC).

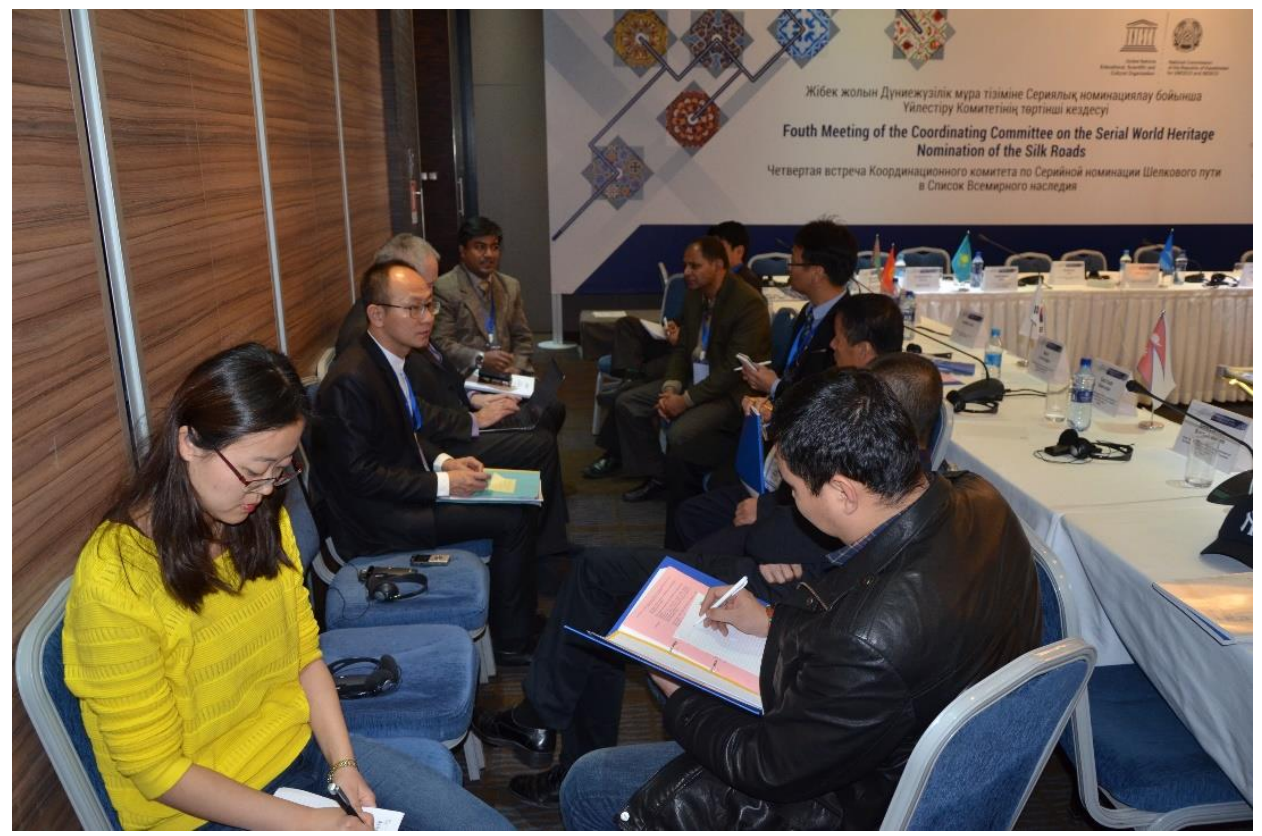

Figure 45. The South Asian representatives discussing strategy and progress.

A productive discussion was held to review progress and ways forward with the South Asian Silk Roads project. This identified a number of key issues.

On the positive side:

1) Evident that good progress had been made at some National levels, especially Nepal with research on the Lumbini-Mustang corridor (see Section 1).

2) Progress is also being made by Nepal and Bhutan in developing and enhancing National Inventories. Both State Parties are planning to use the ARCHES system (see Section 1), and there may be considerable benefits in developing a dialogue between the two in its development and implementation. The Korean-Funds-In-Trust generous support for this process was acknowledged.

3) The potential contribution of Pakistan to the discussion of trans-Himalayan routes was recognised and encouraged. The development of further dialogue regarding routes through Pakistan was seen as important - to the north-west with Afghanistan, to the north-east with India and China, and to the south-east with India.

Issues that need attention (see Section 1): 
4) The development of dialogue with India seems to have weakened since the retirement of Dr B.R. Mani, Assistant Director General of the Archaeological Survey of India (ASI). It was not clear who had taken on the responsibility for the South Asian Silk Roads within the ASI and this needed to be resolved in order to develop future participation.

5) The participation of China in the project appeared to be currently lacking official support. Whilst dialogue had taken place at the last South Asian meeting in Nepal, which included Prof Lyu (Lu) Zhou (from Tsinghua University, Director of National Heritage Centre and Vice-president of ICOMOS-China, and an expert in the 'Tea \& Horse Routes'), it seems that National Commission of UNESCO China and the State Administration of Cultural Heritage are not yet engaged in the project. This needs to be addressed if the South Asian project is going to effectively progress.

Future development:

6) The potential participation of Bangladesh and Myanmar was discussed, and it was suggested that initial dialogue should be developed.

7) The future support of the Korean-Funds-in-Trust was seen as central to the development of effective dialogue within the region for this project.

\subsubsection{Almaty agreement}

The results of the meeting are summarised in the Almaty Agreement (see Appendix 4).
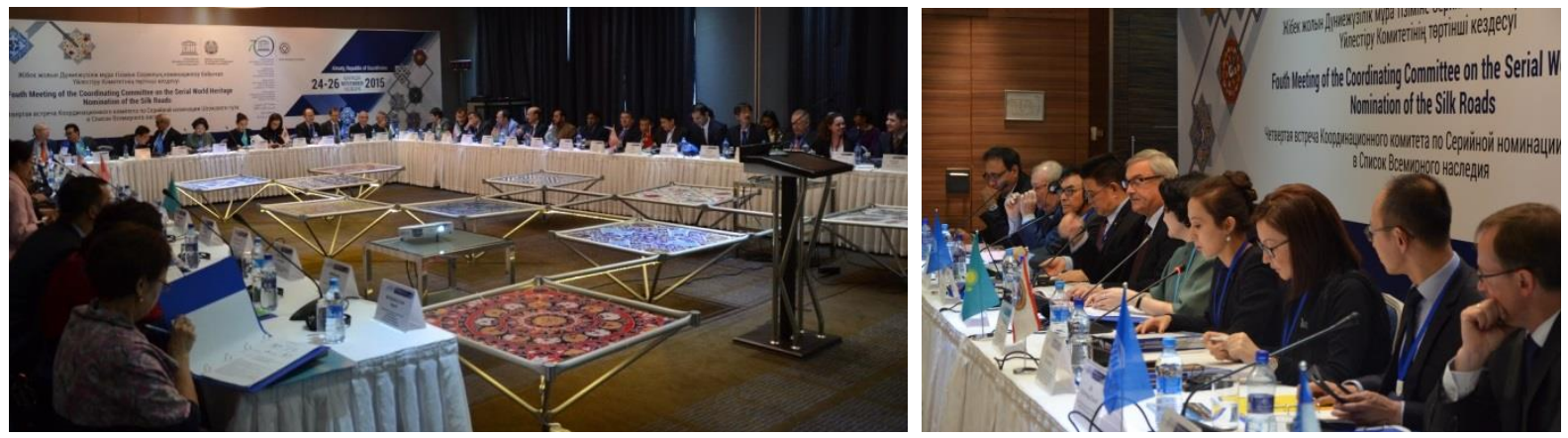

Figure 46. The Almaty meeting in progress.

In terms of the South Asian project, the crucial conclusion was:

8. To encourage close consultation and coordination between Nepal, Bhutan, China and on the preparation of the South Asian Silk Road World Heritage Nominations, and express the desire to continue the UNESCO/Korea Funds-in-Trust South Asian Silk Roads project (Phase II), and encourage Pakistan and other related South Asian countries to join this nomination process. 


\section{Nepal: Field expedition to Lumbini-Mustang corridor (January 2015) ${ }^{18}$}

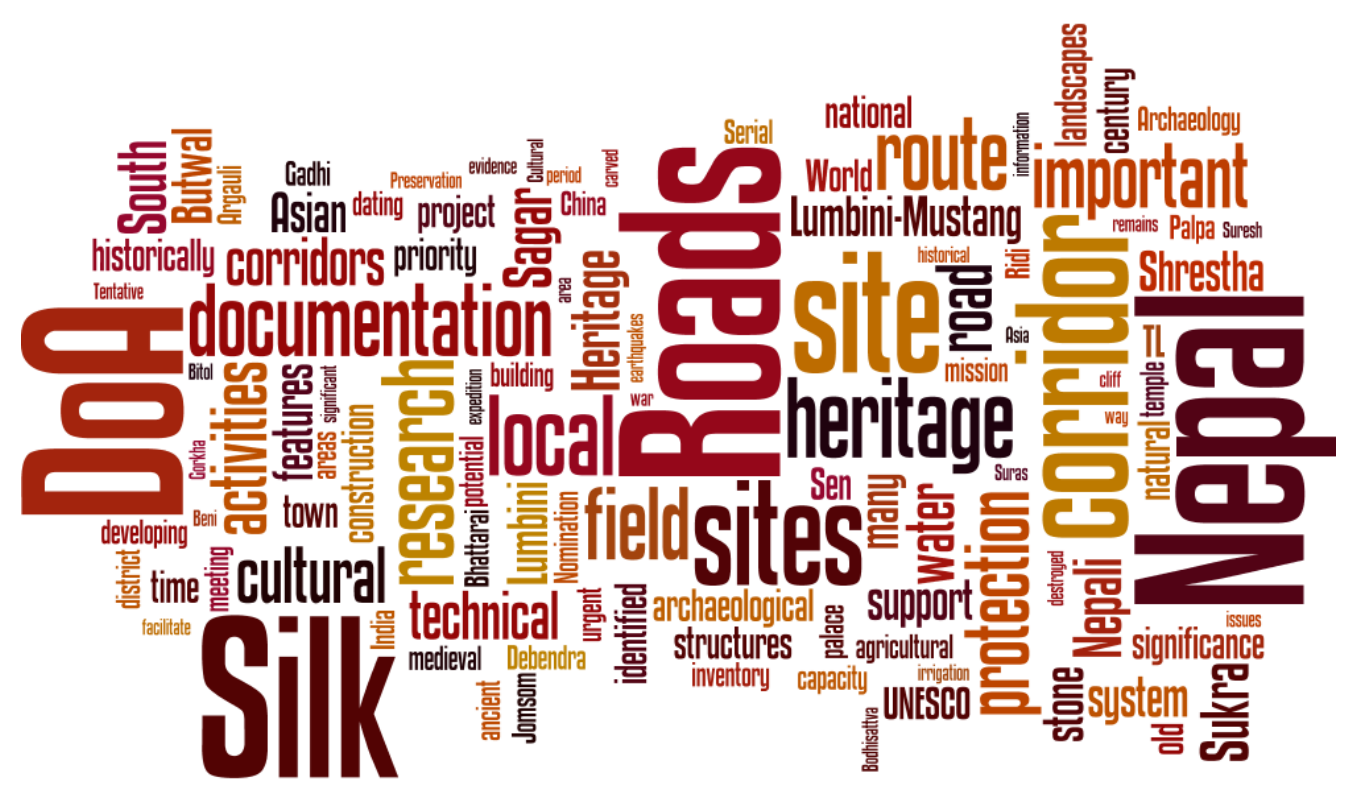

\subsection{Background}

A field expedition was undertaken (26-30 January 2015) to assist in the implementation of the national activities for the South Asian Silk Roads initiatives in Nepal. The mission was organized by the Department of Archaeology (DoA) as part of the plan of actions prepared within the framework of UNESCO contract issued to the DoA, under the UNESCO/Korean Funds-in-Trust project, "Support for the Preparation for the World Heritage Serial Nomination of the Silk Roads in South Asia" (2013-2016), to facilitate and provide technical support for Nepali national Silk Roads activities.

\subsection{Aims}

The field project focused on developing documentation and research along the Silk Roads corridor from Lumbini (in Rupandehi district) to Ghansa (Mustang district); a corridor which Nepal expressed a strong preference to be their priority at the September meeting in Kathmandu. The route meets the Indian Silk Roads corridors to the south in Ganges; but the link with Chinese corridors in Tibet still requires more research.

\subsection{Participants}

The mission was undertaken by Nipuna Shrestha and Christian Manhart (UNESCO Kathmandu), Suresh Suras Shrestha and Debendra Bhattarai (Department of Archaeology (DoA) of Nepal), and a national expert, Sukra Sagar Shrestha (formerly Chief Archaeology Officer at the DoA). 


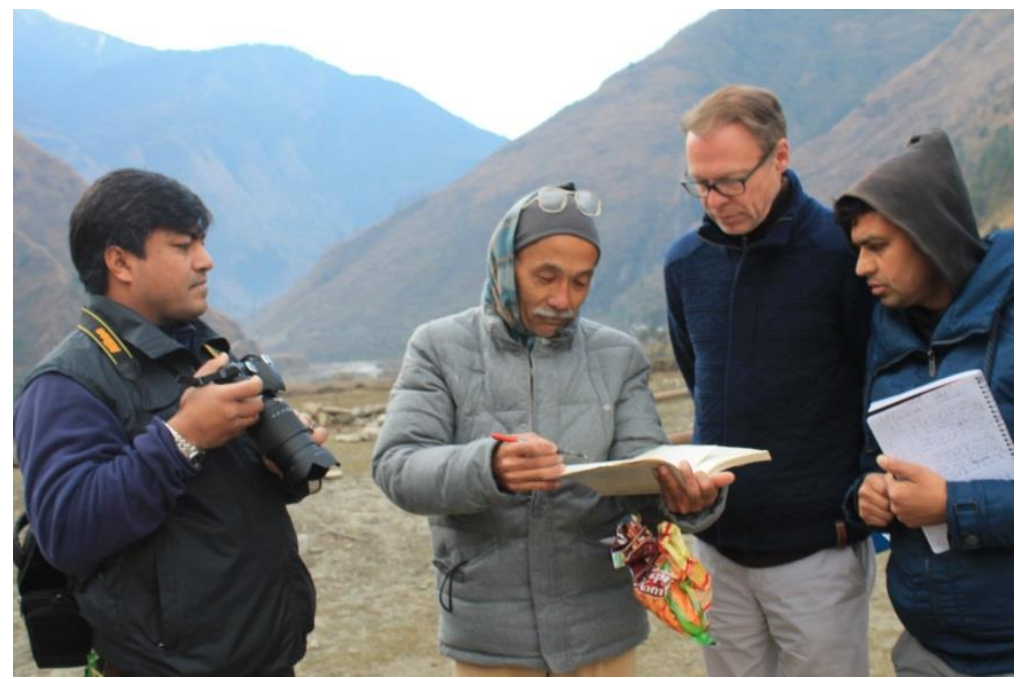

Figure 47. Sukra Sagar Shrestha describing to Christian Manhart, Suresh Suras Shrestha and Debendra Bhattarai the importance of a site along the route.

\section{$5 \cdot 4$ Activities}

This project was also directly supported by the purchase of equipment (digital camera, climate friendly storage devices, GPS units, etc.).

In the afternoon of the first day, 26 January 2015, a short meeting took place in Lumbini with Roland Lin (UNESCO WHC) and the DoA staff regarding UNESCO's proposed technical assistance on South Asian Cultural Landscape initiatives in Nepal. It was agreed that four main areas of proposed activities could be envisaged for Nepal:

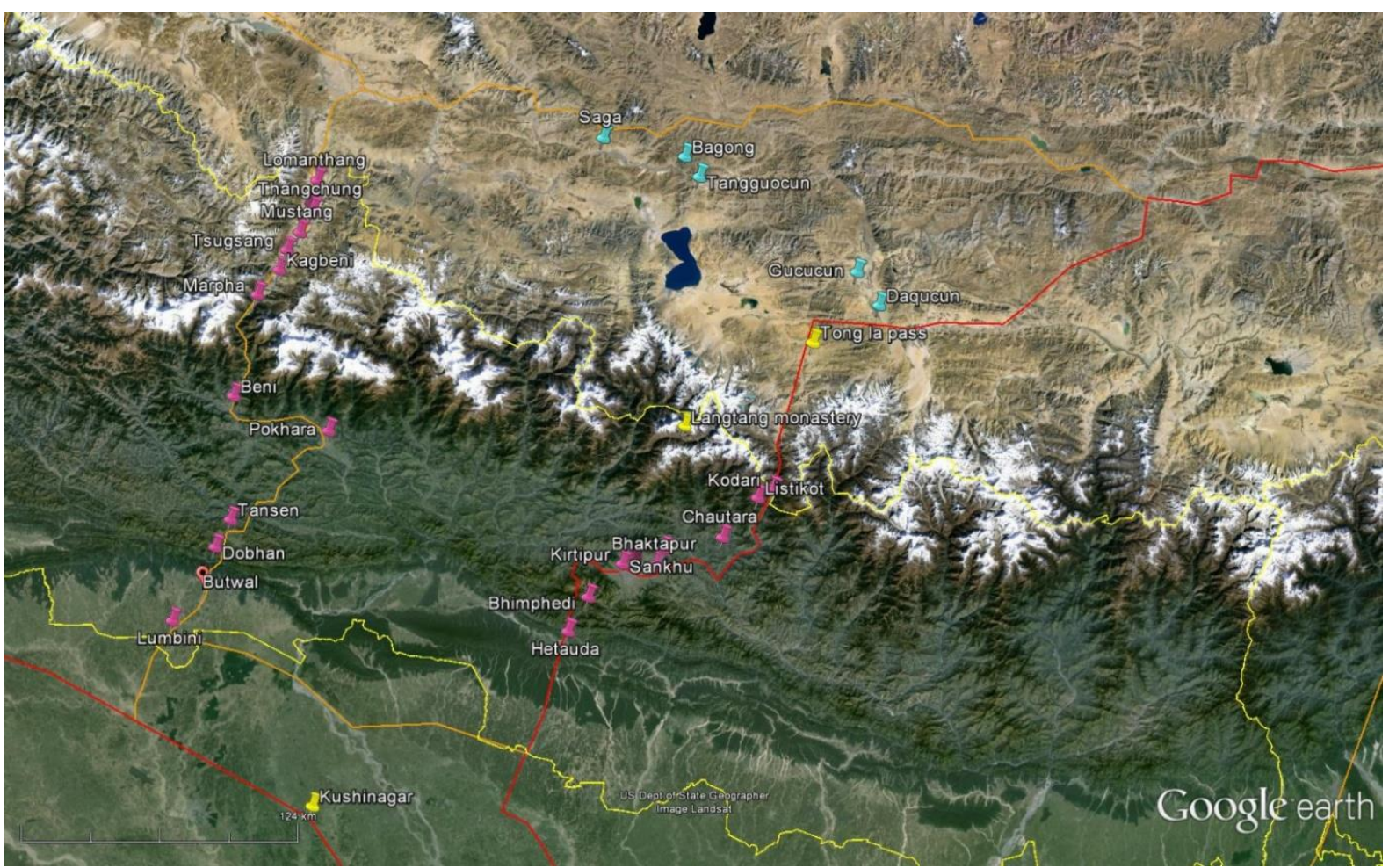

Figure 48. The Lumbini-Mustang corridor (Google Earth).

- Legal system for the protection of cultural landscapes: DoA would consider, within the current amendment of the Ancient Monument Preservation Act 2013 (1956), how legislation regarding heritage routes/corridors could be reflected/incorporated;

- Potential Tentative List (TL): DoA would consider a review of the sites that could come 
under cultural landscapes, as part of the exercise to update the Tentative List for World Heritage Serial Nomination of the Silk Roads heritage corridors;

- Inventory and capacity building: DoA stressed the need of preparing inventories of potential sites and capacity building of related stakeholders;

- Heritage corridors: The Silk Roads heritage corridors could also encompass cultural landscapes, and the DoA could benefit from Silk Roads field explorations and on-going documentation work to understand the issues involved in nominating future cultural landscapes in Nepal.

From 27 to 29 January, starting from Lumbini, a series of historical sites were observed:

1. The site of Jit Gadhi, near the Tinau River in Butwal, which together with Nuwakot Gadhi and Kathe Gadhi, are the sites where the Gorkha war (1814-1816), or the AngloNepalese war, was fought between the Kingdom of Gorkha and the British East India Company, and where Nepali troops defeated the British. The site included the exposed brick walls of forts and associated structures (including an underground passage). Archaeological excavation is currently being undertaken by a DoA team. The date of the site excludes it from the Silk Roads project.

2. The old Batauli and Khasyauli bazaar of Butwal (main gateway to Western Nepal), alongside the Tinau River. These are historically important commercial centers. It seems that very little remains of the ancient town. Further research and documentation on the settlements will be required to demonstrate its significance and to define its contribution to the overall significance of the Lumbini-Mustang corridor.

3. Palace of Mani Mukunda Sen in Butwal: This was the winter palace of the Sen clan of Palpa, who ruled during 15-16th century. A free standing northern wall and other parts of a ruined palace are in dilapidated condition. The ruins are set within a brick enclosure and are a part of a larger site demarcated as a park under the local management of Butwal Municipal office. The site needs urgent protection, including technical support regarding appropriate development, regular maintenance, developing the awareness of workers employed nearby in activities such as tree-cutting and construction. Further research and documentation is needed to justify its significance for the LumbiniMustang corridor.

4. Sainamaina in Bitol (some 11-12 $\mathrm{km}$ west from Butwal): the site displays archaeological richness. According to Prof Gitu Giri, who conducted research here under CNAS, Tribhuvan University, in 1993, 2003, 2005 and 2013, it is one of the two main cities (Samagama and Mainapur according to Buddhist literature) of ancient Kapilvastu during the Shakya period. The site contains various features, of both habitation and monumental structures, including wells and kuwas (a form of traditional water source), and numerous fragments of pottery, terracotta animal figurines, coins, beads, weapons, slabs, etc. Parts of stone temple structures, such as a temple door lintel, dressed stone roof slab, and makara head were found scattered across the area. Near Ranikuwa was an outstanding intricately carved stone statue (Figure 49), which Sukra Sagar identified as Padmapani (Bodhisattva), possibly dating to the 8th to $10^{\text {th }}$ century (based on the details and iconography). All are on the side of the road, with no protection. Locals said that there are many historically important fragments of antiquities scattered in this area (there was not adequate time to further investigate those sites). The site is highly vulnerable to treasure hunters, although Nepal has little or no past experience of illegal excavation. The overall site is predominantly agricultural land, with few local residences, although there are indications that new houses are coming and on top of the nearby northwestern hill a large construction was said to be the work of the Army. Sukra Sagar also warned that the use of pesticides for cultivation in the agricultural land could be potentially dangerous to the archaeological remains. It was discussed whether the site needs to be brought under the immediate protection by DoA, in close cooperation with the local district development committee, to control inappropriate activities and new building. It was also seen as important to map the archaeological resources to help protect them from further destruction. Some of the archaeological finds from the site are to be displayed in Lumbini Museum, already under the protection of the Government of 


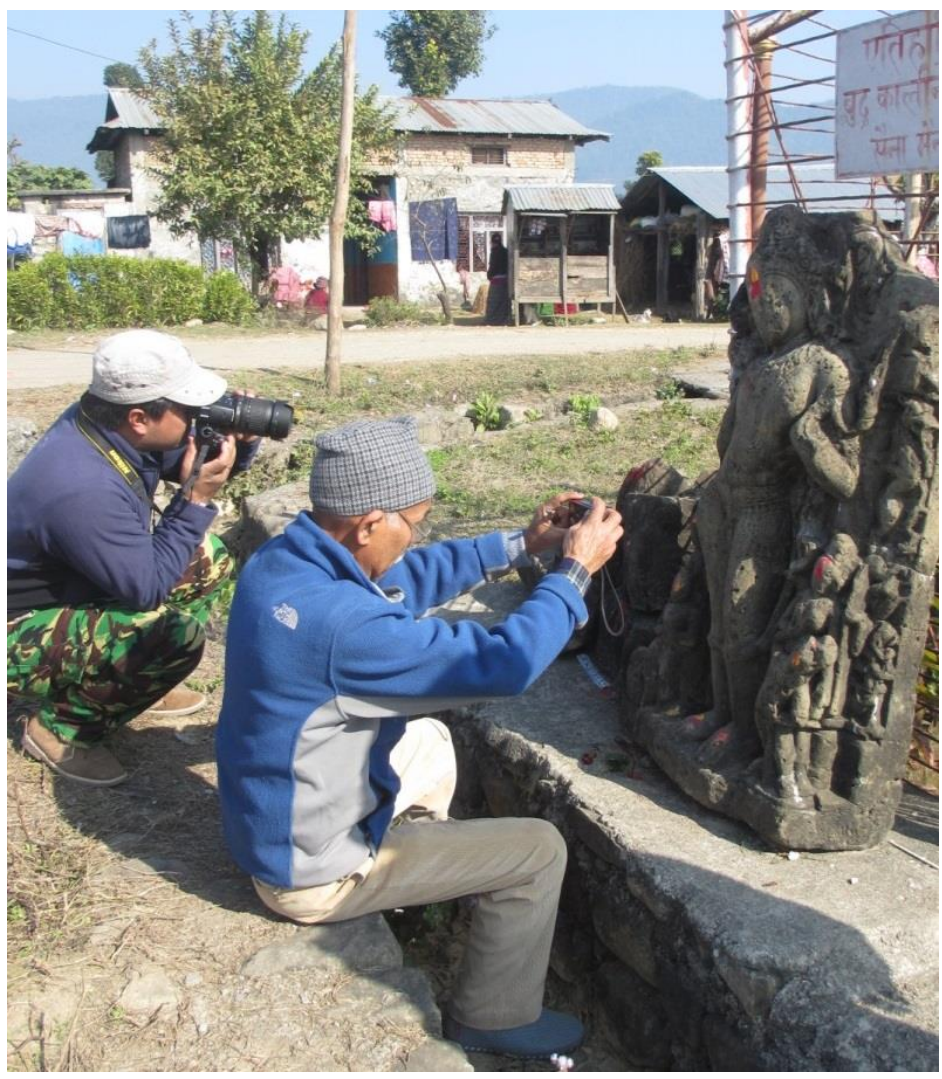

Figure 49. Sainamaina, Bitol: an intricate carved statute, possibly of Padmapani (Bodhisattva) and dating the 8-10 century.

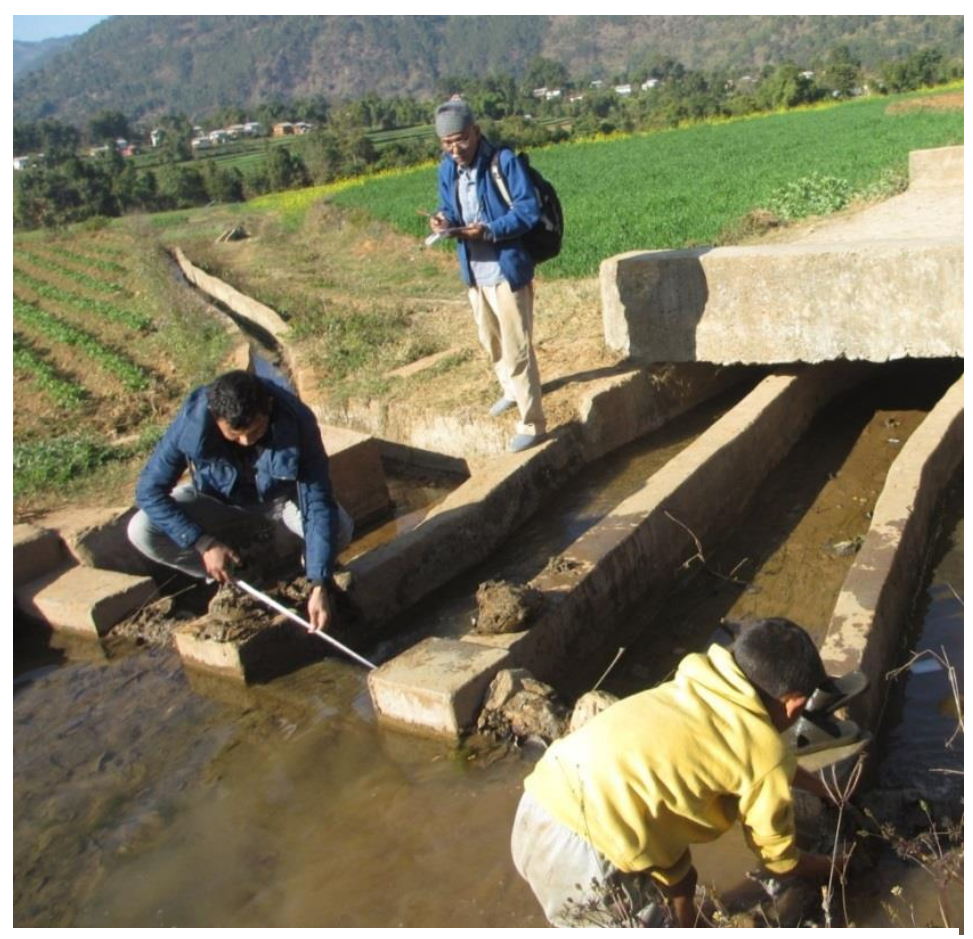

Figure 50. Argauli: locally managed irrigation systems. Debendra Bhattarai (DoA) is measuring the width of canal, while a local boy is managing the water flow, directing water from one field to another using lumps of soil.
Nepal. The site demonstrates significant features (attributes) and is one of the potential sites to be considered under the TL for the Silk Roads heritage corridor.

5. On the way from Palpa to Ridi, there are two historically important sites: as Purano Kot (said to be a palace of later Sen period) and Bhairabsthan. However, due to lack of time, it was not possible to observe these.

6. Argauli: Sukra Sagar and the DoA colleagues suggest that this site displays a locallymanaged agricultural irrigation system for growing rice (Figure 50), with water delivered to each field in proportion to the field size. Earth and stones are used as dividers, to obstruct or open the flow of water. Locals stated that four such canals are currently operational in Argauli, irrigating upper and lower catchment areas. Sukra Sagar considers that this system came from the North, probably Central Asia. The current system uses modern materials (cement), but further review would be useful to explore whether this is an indigenous technology, or part of the cultural interactions along the Silk Roads.

7. Ridi, a riverside town, historically important for pilgrims. A local priest also suggested that it played a role as part of ancient route to Muktinath and Damodar Kunda, two important Hindu pilgrimage sites. There was not time to visit the Ridi settlement, which is said to have an intact medieval character. The medieval temple complex, Rishikesh, dating to the Sen Period 1518th century, is on the current 
TL. Some old structures exist, but there are also a number of new constructions, not appropriate to the site.

8. The medieval town of Tansen, on the TL, was briefly observed. The durbar has been totally rebuilt after it was burnt down during Maoist insurgency. The town has undergone many new constructions and has already lost much of its significant historical fabric. This town's relationship to Silk Roads corridor is yet to be explored: the DoA plans to accumulate information with stakeholders and local experts.

9. The route from Palpa via Pokhara and Beni up to Tatopani: the route, particularly from Tatopani to Ghansa, provides views of mountain peaks such as Annapurna, Nilgiri, Tukuche and Dhaulagiri, and demonstrates outstanding topographical and natural features, and areas of exceptional natural beauty. This part of the route has a strong consideration under natural criteria. Another feature is the world's deepest gorge at Kaligandaki, 6,00om deep. The Rupse waterfall is said to be the tallest water fall in Nepal.

10. The road up to Jomsom and Tshuksang: A large rock shelter may have been destroyed during road construction ${ }^{19}$, while the rock-hewn trail (Figure 51), above the present road in the stone cliff, is strong evidence of this part of the Silk Roads corridor.

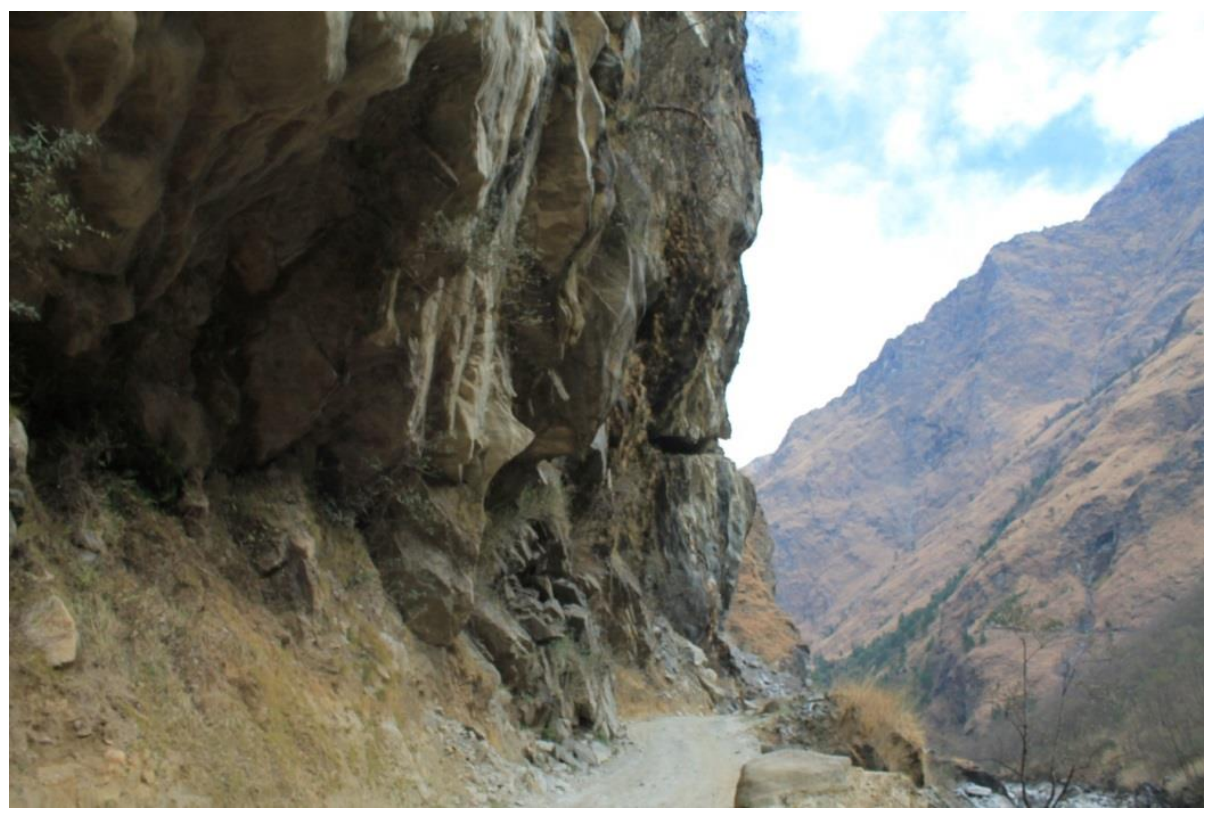

Figure 51. Mustang-Lumbini corridor, Nepal: a rock shelter on the way from Beni to Jomsom may have been destroyed during road construction, but parts of a rock-hewn trail, in the stone cliff above the present road, still exists.

\subsection{Conclusion \& recommendations}

The section of the Lumbini-Mustang corridor that was visited is certainly extraordinary, but there are only few sites that might be nominated in a Silk Roads corridor. However, in terms of cultural exchange, and the use of the route over time, this section's significance should not be underestimated. In addition, the road travelled was not always same as the old trade route, and there must be other important features that the current mission did not see. The DoA must continue to look for evidence through additional research, trekking the old route and local consultations.

There are many challenges in developing the Nepal section of the Silk Roads. In order to make the best possible use of scarce resources it is important to build on existing knowledge.

Important issues arise: 
- The information collected by mapping identified heritage sites (cities and settlements), combined with inventory and detailed research, needs to be systematically compiled and recorded. The capacity for scientific documentation has to be built within the DoA.

- This again raised the possibility of Nepal adopting a digital National Inventory system;

- There is an urgent need to ensure that protection for sites and specific features (e.g. petroglyphs left unprotected at Eklebhatti beyond Jomsom), under local planning laws, if not under the Ancient Monument Preservation Act 2013 (1956), is put in place. As there are no adequate regional or local offices of the DoA, there is a need for formal collaboration with local authorities (Municipalities, DDCs, and VDCs), and a clear understanding of what aspects of protection are needed to ensure their protection.

- ICIMOD have expressed their interest in providing technical assistance to Nepal's DoA in heritage sites documentation along the corridors (see Section 4.6.5). In addition, the Kailash Sacred Landscape Conservation and Development Initiative could be a potential World Heritage nomination.

\subsection{The Nepal earthquakes of 2015}

Due to urgent priorities pertaining to recovery measures following the severe earthquakes that hit Nepal on 25 April and 12 May 2015, which caused extensive damage to many heritage sites in Nepal, two activities within Nepal were not able to advance as foreseen.

1. Facilitation and technical support for Nepali national Silk Roads activities, including undertaking field expeditions/ field research for inventory preparation and documentation of identified priority Nepali corridor/s. As reported in 2014 (above), field research had been organised in January 2015 for inventory preparation and documentation of identified priority Nepali corridor/s. However, within 2015, only limited consultation was made at Tansen, one of the nodal towns between on the Lumbini - Lo Manthang Corridor;

2. Facilitation and technical support for DoA staff to work with ICIMOD experts to enhance scientific documentation of cultural heritage along the Nepali heritage corridor(s).

In addition, due to the many problems that resulted from the natural disasters in Nepal, it was difficult for Nepal to undertake the planned bilateral meetings with India and China, to establish a steering committee and working group. However, official correspondence was initiated by DoA, Nepal early in 2015, with the State Administration of Cultural Heritage of China.

As a result, UNESCO took the opportunity to host the presence of the four related States Parties (China, India, Nepal and Bhutan) at the 4th Meeting of the Coordinating Committee of the Serial World Heritage Nomination of the Silk Roads, held 23-27 November 2015, in Almaty, Kazakhstan (see below). The aim was to assist and facilitate the establishment of South Asian Silk Roads Steering Committee and Working Group, for the first South Asian priority transnational Silk Roads heritage corridor(s), and to support a first meeting of the South Asian Silk Roads Working Group. 


\section{Complimentary Activities: Bhutan National Inventory}

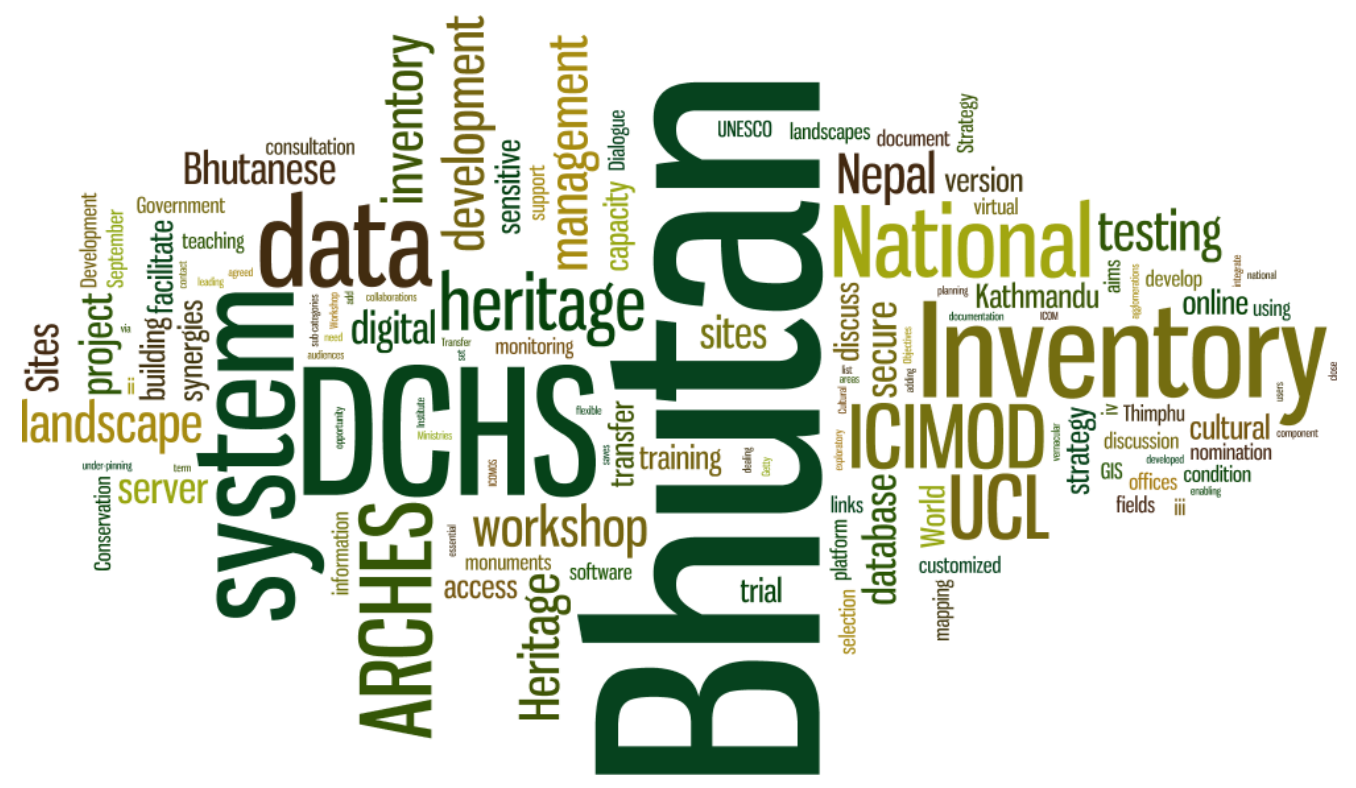

\subsection{Strategy}

\subsubsection{Introduction}

The development of the strategy followed an exploratory mission and workshop conducted in Thimphu in August 2014 (see Section 4.5), between experts from UCL the DCHS and UNESCO. The forward strategy and stages were discussed during that workshop and were set out in a draft forward strategy.

The sub-regional workshop on the Nomination Strategy for the South Asian Silk Roads, held 23-24 September 2014 in Kathmandu, Nepal (see above), provided a useful opportunity to further discuss the development of the inventory programme. Subsequently Nepal has also decided to explore ARCHES as a platform for their heritage inventory (see Section 1). There are possibilities for a strong regional development and skills sharing process. 


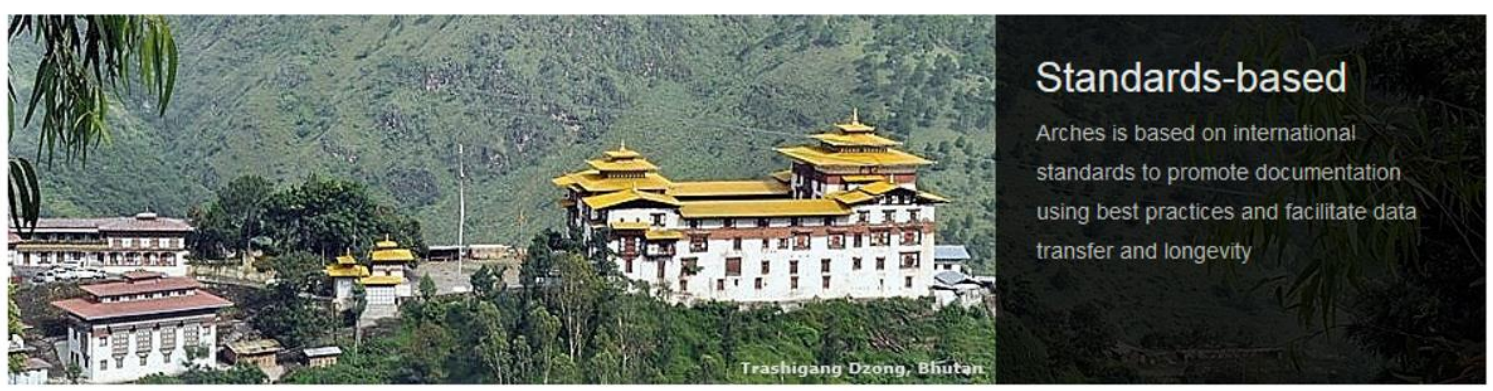

\section{Arches: Heritage Inventory \& Management System \\ Arches is an open-source, web-based, geospatial information system for cultural heritage inventory and management. Purpose-built for the international cultural heritage field, Arches is designed to record all types of immovable heritage, including archaeological sites, buildings and other historic structures, landscapes, and heritage ensembles or districts.}

Why Arches?
Arches is purpose-built for the
cultural heritage field. Learn
more about its many features,
and how you or your
organization may benefit from
using it.

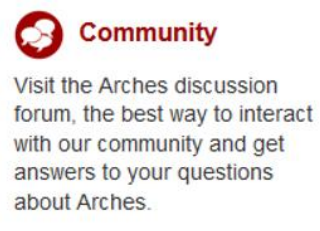

See Arches! Get Arches!

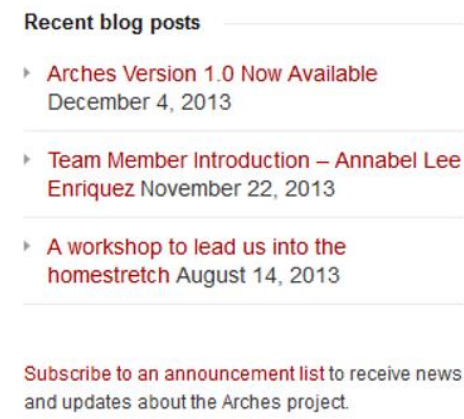

A workshop to lead us into the homestretch August 14, 2013

Subscribe to an announcement list to receive news and updates about the Arches project.

Figure 52. The ARCHES inventory system. A screenshot from the project website (http://archesproject.org/).

The mission also enabled discussion with ICIMOD over their developments in landscape mapping and documentation approaches (see separate short mission report on the workshop). This suggests that there may be fruitful synergies between the development of the Bhutanese inventory and the ICIMOD work. The landscape component of the Bhutan Inventory is clearly crucial, and as discussed in the way forward document, it will be important in Bhutan to integrate heritage management, recognition and protection with ecological and landscape management. It will also be import to develop close links between the DCHS and other ministries and agencies dealing with the natural environment. ICIMOD have strong geospatial teams and are already engaged in work in Bhutan with various Ministries. It is suggested that we explore, during the design phase, the potential links with ICIMOD and the potential to seek assistance form ICIMOD in the capacity building activities in Bhutan.

\subsubsection{Objectives for the Bhutan National Inventory}

The workshop extensively discussed the aims of a National Inventory system, with specific reference to the needs of Bhutan. Since the ratification by Bhutan in 2001 of the World Heritage Convention the issue of a National Inventory has been raised, as a platform upon which to discuss the criteria for the selection of specific monuments, sites or landscapes for nomination.

After discussion, the aims of a Bhutanese National Inventory were summarised as:

1. To disseminate information and raise awareness of cultural heritage sites in Bhutan; to both national and international audiences

2. To create a knowledge-based context for the preservation, promotion and management of cultural heritage in Bhutan

3. To document the condition, state of conservation, management planning, and changing circumstances of the heritage in Bhutan

4. To provide a robust under-pinning for the selection of monuments, sites and landscapes for any potential World Heritage nomination. 
It was agreed that the Inventory should reflect the three categories of cultural heritage in the current draft legislation:

- Heritage Buildings (including sub-categories of religious buildings, vernacular architecture, etc.)

- Archaeological Sites

- Cultural Sites (which encompass landscape areas and agglomerations of historic and archaeological elements) ${ }^{20}$

It was also noted that the inventory would need to hold some potentially sensitive information (such as ownership issues, condition reporting, conservation/restoration decisions, and the location of some sensitive sites). It would therefore be essential that any Inventory system was flexible, and that public access to data, while as wide as possible, was still able to be managed for sensitive material.

\subsubsection{Way forward: the first steps}

6.1.3.1 Stage 1 - Design

i) Development by UCL of data fields from existing Bhutanese digital data; and compilation of term lists (architectural, descriptive, geographic, etc.) based on existing digital data and comments for DCHS. To facilitate this UCL will establish a secure online thesaurus list to enable DCHS to comment and provide additional terms.

ii) Cleaning and preparation by UCL of existing digital data for transfer to new system.

iii) Development of ARCHESv3 for Bhutan pilot project.

iv) Dialogue between DCHS, UCL and ICIMOD on potential collaborations and future support for capacity building in Bhutan. This will start via email contact but follow this up with a meeting in the ICIMOD offices in Kathmandu.

v) Meeting with Nepal Dept. of Archaeology and UNESCO office to discuss synergies in the development of ARCHES in Nepal \& Bhutan.

\subsubsection{Stage 2 - Pilot phase}

i) Installation by UCL of the Bhutan National Inventory on secure virtual server, to facilitate the online access of the system by the DCHS for testing and trial data entry.

ii) A one week introduction to the system by UCL expert, Bryan Alvey: enabling testing, training users, setting-up password permissions, etc.

iii) A six month testing period - with the DCHS adding new data and testing the system functionality.

\subsubsection{Stage 3 - Transfer to DCHS}

i) DCHS establishing a secure network and server in new DCHS offices, leading to the transfer of the National Inventory system to a local Bhutanese server by September 2016.

\subsection{Implementation}

The project was a follow-up to the earlier initiatives in Bhutan and was intended to develop capacity building of the Division for Conservation of Heritage Sites in Bhutan by developing a new database system using ARCHES (currently version 3) with the technical support of the UCL team. ARCHES ${ }^{21}$ is a system of inventory and database management developed by Getty Conservation Institute and the World Monuments Fund in consultation with ICOM and ICOMOS, which is becoming widely used amongst heritage professional. ARCHES is open source software that can be customized, updated, and extended with new features.

${ }^{20}$ Elsewhere these have often been defined as Cultural Landscapes, but in Bhutan this concept applies to the whole country.

${ }^{21}$ ARCHES - see http://archesproject.org/ 
The project sought to:

- Develop data fields from the existing database of the Government of Bhutan in consultation with DCHS;

- Develop customized database system for Bhutan using ARCHES version 3;

- Clean the existing digital data of the Government of Bhutan and transfer into new ARCHES system;

- Install Bhutan National Inventory on secure virtual server, to facilitate the online access of the system by the DCHS for testing and trial data entry;

- Provide a one-week training in Bhutan to the DCHS officers for the basic use of the system;

- Monitor the trial data entry by the DCHS officers;

- Organize a monitoring mission to Bhutan to assess the progress of work by DCHS;

- Provide training on GIS to the DCHS officers on the occasion of the above monitoring mission.

\subsection{Support for Bhutanese capacity}

Support was provided, through the generous support of the Korean Funds-in-Trust and organised by the UNESCO New Delhi office, to support the DCHS in its implementation of the ARCHES system

\subsubsection{Equipment}

Support was provided to procure a server to support the implementation of the ARCHES system.

This comprised:

1. Server: Intel Xeon E5 series with $3.0 \mathrm{GHz}$ processors, RAM 16GB RAM, Memory 20MB, Storage 2TB,4x1GB Ethernet NIC, RAID controller/Hot swap, LCD 17" screen and redundant power supply

2. Server Rack $36 \mathrm{U}$

3. UPS 3 KVA -APC Brand

6.3.2 Staffing

Support was provided for an IT Officer, who is working towards the establishment of the Database and Inventory System.

Recruit two new staff to work on the Inventory project, for data entry and development. These would assist the DCHS in field survey, data collection, data review and data entry into the National Inventory.

\subsubsection{Meetings}

Resources to assist the DCHS in hosting and providing meeting logistics, at the DCHS offices, for various workshops and training sessions.

\subsection{Activities prior to the February 2016 workshop}

In November 2015 a series of activities were agreed with the DCHS to be undertaken in advance of the ARCHES workshop in February 2016 (see below).

\subsubsection{Activities}

1) Field names: clarifying the fields in the existing digital database.

2) Site locations: the best site locations that can be established for all of the sites listed in the original data set. This will enable the upload the data in to the ARCHES database with a spatial dimension. This is a substantial task for the 2,448 monument records at present. - It does not matter what coordinate system is used - including DrukRef - although decimal degrees (Lat/Long) would be preferred. 
- A centroid for each monument complex will suffice to start with.

3) Digital data: there is a need to understand the scale, availability and format of digital data from the sister agencies in Bhutan. Most of the other Ministries in Bhutan have adopted an ESRI ArcGIS platform for handling geospatial data. The DCHS will need to both transfer National Inventory data to other departments (primarily to ensure input into strategic and local planning initiatives) and to be able to incorporate data sets generated by other agencies (such as land use, ownership or ecological data) into the Inventory. It would be useful to:

a) Establish contact with all relevant Ministries and explore their current (and planned) digital data holdings. It is particularly interesting whether they have (georeferenced if possible) maps, satellite images, digitised information (such as Dzongkhag and Gewog boundaries), etc.

b) Document the holdings that they are prepared to share, the format of the data (raster files, shapefiles, geodatabases, etc.), and, if possible, acquire copies in advance of Workshop 2.

c) The National Statistics Bureau of Bhutan's National Map Portal seems to show the geographic locations of historical monuments and have administrative data. It would be interesting to know what format they hold their data and their willingness to share it.

4) The Cultural Atlas of Bhutan, a current initiative at the Royal University of Bhutan, and supported by the Oriental Cultural Heritage Sites Protection Alliance, provides an opportunity for collaboration between the DCHS and the University, and a useful opportunity for exchange of data. It is suggested that this should be explored at the earliest opportunity, as the early establishment of data areas and data exchange protocols could feed into the Inventory design process.

5) Intangible Heritage: At present intangible heritage in Bhutan is the subject of a draft legislative initiative. As this develops it is likely that an inventory approach will be required, so it will be important to consider how this relates to the National Inventory currently under development, not least because the relationship between tangible and intangible heritage has blurred lines: for example, the performance and character of festivals within the space bounded and delimited by the materiality of Dzongs. It is inconceivable that any nomination of the Dzongs would not encompass the continuity of social and religious practice, so developing a linked-up strategy on this issue is crucial.

6) Existing non-digital data: there is a wide range of existing non-digital data in the archives of the DCHS and other organisations. The DCHS has monument-specific inventories, including detailed paper-based catalogues. In addition there are numerous hand-drawn plans, maps, and conventional photographic records. In addition, there are published and documentary sources which would be extremely useful to integrate into the National Inventory. As a preliminary task a basic computerised index of the documentation available for each site (just a brief description of scale of files, documentary data, images, drawings, etc.) would be very useful for assessing the scale of digitisation required and as a baseline audit of the existing conventional archive. This data will be crucial in both helping to prioritise future data enhancement and considering future resourcing.

- $\quad$ Basic computerised list of monument records, including written data, scale of historic photographs, number (and size) of conventional plans, etc. - per monument complex;

- $\quad$ Basic listing of other data - documentary sources, survey data, etc.

7) Scanning existing archival data: it would be useful to have some scanned data in advance of Workshop 1, to train staff in the inputting and management of such material. Suggest:

- $\quad$ Scan a range of photographs (at least 100) and plans (at least 20 at varying sizes) relating monuments that are in the existing digital data (and thus will be already loaded into ARCHES);

- $\quad$ Scan some documents (at least 20) that relate to monuments that are in the existing digital as PDF files. These could be standalone files that you would want to attach 
to specific monument records - for example, a detailed report on condition at a specific point in time, or a report on conservation work.

\subsubsection{Priorities}

The priorities were agreed as: (1) Clarification of field names; (3) Establishing what digital data might already be available; which might ease task (2) on site locations (which is a large task if undertaken manually); (6) Understanding the scale and depth of existing resources (this is vital before the workshop); (7) Scanning a sample of data to work with at the workshops.

\subsubsection{Thesauri}

Discussions took place via email regarding the development of thesauri for the Bhutan Inventory. These covered two main areas: monument types and chronological periods.

\subsubsection{Monument types}

These are still under development, but the main monument types, depending upon architectural and functional form are shown in Table 2.

Table 2. Initial terms for monument thesaurus.

\begin{tabular}{|c|c|c|}
\hline $\begin{array}{l}\text { Monument } \\
\text { type }\end{array}$ & Specific terms & Explanation \\
\hline \multirow[t]{10}{*}{ Lhakhang } & Lhakhang & General term for the Buddhist temple \\
\hline & Neykhang & A shelter for local deities \\
\hline & Goenkhang & $\begin{array}{l}\text { A separate structure, or sometimes a part of } \\
\text { Lhakhang, which serves as the seat of protecting } \\
\text { deity }\end{array}$ \\
\hline & Kuenrey & Congregational or meeting hall for the monk body \\
\hline & Lamai Lhakhang & $\begin{array}{l}\text { A structure dedicated to Buddhist masters in the } \\
\text { past }\end{array}$ \\
\hline & Zandopelri & $\begin{array}{l}\text { Similar to Lhakhang, it is the structure believed to } \\
\text { be replication of Guru Rinpoche's celestial abode }\end{array}$ \\
\hline & Choekhang & A place of offering \\
\hline & Tshokhang & $\begin{array}{l}\text { Gathering room for monk body - serves same } \\
\text { purpose as Kuenrey but smaller scale }\end{array}$ \\
\hline & Dochey & Courtyard \\
\hline & $\begin{array}{l}\text { Other terms to be } \\
\text { considered: } \\
\text { Prayer hall } \\
\text { Ordination Hall } \\
\text { Buddha Image Hall } \\
\text { Sermon Hall } \\
\text { Scripture Hall } \\
\text { Chaitya } \\
\text { Belfry } \\
\text { Crematorium } \\
\text { Cloister } \\
\text { Refectory } \\
\text { Dormitory }\end{array}$ & \\
\hline \multirow[t]{3}{*}{ Dzong } & $\begin{array}{l}\text { Many of the same } \\
\text { buildings/spaces as } \\
\text { Lhakhang }\end{array}$ & \\
\hline & Utse & \\
\hline & Bodhi tree & \\
\hline $\begin{array}{l}\text { Choeten } \\
\text { (stupa) }\end{array}$ & $\begin{array}{l}\text { Tashigomang choeten } \\
\text { Yerndum Choeten } \\
\text { Padpung Choeten } \\
\text { Choethrul choeten }\end{array}$ & $\begin{array}{l}\text { Tibet uses a variety of terms - Lotus Blossom } \\
\text { Stupa; Enlightenment Stupa; Stupa of Many } \\
\text { Doors; Stupa of Descent from the God Realm; } \\
\text { Stupa of Great Miracles; Stupa of Reconciliation; }\end{array}$ \\
\hline
\end{tabular}




\begin{tabular}{|c|c|c|}
\hline & $\begin{array}{l}\text { Labab Choeten } \\
\text { Namgyal Choeten } \\
\text { Nyangda Choeten } \\
\text { Jangchub Choeten } \\
\text { Mithrub Choeten } \\
\text { Khangzang Choeten } \\
\text { Lubung Choeten } \\
\text { Namgo Choeten }\end{array}$ & $\begin{array}{l}\text { Stupa of Complete Victory; Stupa of Nirvana, } \\
\text { Kalachakra stupa - which we may try to map } \\
\text { across }\end{array}$ \\
\hline \multicolumn{3}{|c|}{ Naktshang } \\
\hline \multicolumn{3}{|c|}{$\begin{array}{l}\text { Domestic } \\
\text { building }\end{array}$} \\
\hline \multicolumn{3}{|c|}{$\begin{array}{l}\text { Industrial } \\
\text { building }\end{array}$} \\
\hline \multirow[t]{3}{*}{ Bridge } & Cantilever & \\
\hline & Chain & \\
\hline & Covered & \\
\hline
\end{tabular}

\subsubsection{Chronology}

Due to the relative paucity of work on pre $7^{\text {th }}$ century Bhutan, the chronological framework, and terminology, is rather generic. At present, the schema established by Karma Phuntsho (Phuntsho 2013) is the most widely used, but does not offer a comprehensive framework. A broad schema was established (Table 3 ) but this is not sufficiently robust or transferable, and further work will be needed in this area.

Table 3. Bhutanese chronology.

\begin{tabular}{|c|c|c|c|c|}
\hline & & Start & End & Reason \\
\hline \multirow{5}{*}{$\begin{array}{l}\text { Prehistoric } \\
\text { Period }\end{array}$} & & $-\mathrm{xxxx}$ & 649 & \\
\hline & Stone Age & $-\mathrm{xxxx}$ & -9000 & \\
\hline & Neolithic & -9000 & -1400 & \\
\hline & Bronze Age & -1400 & -500 & \\
\hline & Iron Age & -500 & 649 & $\begin{array}{l}\text { End: Death Songtsän } \\
\text { Gampo \& arrival of } \\
\text { Buddhism in Bhutan }\end{array}$ \\
\hline \multirow{3}{*}{$\begin{array}{l}\text { Early Historic } \\
\text { Period }\end{array}$} & & 650 & 1615 & \\
\hline & $\begin{array}{l}\text { Early } \\
\text { Diffusion }\end{array}$ & 650 & 850 & \\
\hline & $\begin{array}{l}\text { Later } \\
\text { Diffusion }\end{array}$ & 851 & 1615 & \\
\hline $\begin{array}{l}\text { Historic } \\
\text { period }\end{array}$ & & 1616 & 1906 & $\begin{array}{l}\text { Start Ngawang Namgyal's } \\
\text { arrival in Bhutan - } \\
\text { beginning of Bhutanese } \\
\text { Kingdom }\end{array}$ \\
\hline $\begin{array}{l}\text { Early Modern } \\
\text { Period }\end{array}$ & & 1907 & 1967 & $\begin{array}{l}\text { Start: Ugyen Wangchuck is } \\
\text { elected Bhutan's first } \\
\text { hereditary ruler }\end{array}$ \\
\hline Modern Period & & 1968 & $\begin{array}{l}\text { present } \\
\text { day }\end{array}$ & $\begin{array}{l}\text { King Jigme Dorji } \\
\text { Wangchuck establishes the } \\
\text { first Council of Ministers }\end{array}$ \\
\hline
\end{tabular}




\subsection{Workshop February 2016, Thimphu, Bhutan}

Organized by the Division for Conservation of Heritage Sites, Department of Culture, Ministry of Home and Cultural Affairs and University College London.

Venue: Office of Department of Culture, Thimphu.

Dates: 11-17 ${ }^{\text {th }}$ February, 2016

\subsubsection{Introduction}

The workshop was focused on the application of the ARCHES heritage inventory system for the heritage sites of Bhutan, and took place from the $11^{\text {th }}$ to the $17^{\text {th }}$ of February, 2016. The purpose of the workshop was to give a comprehensive demonstration of the features offered by the ARCHES system, to introduce the Bhutanese team as to how this system could be used in their day-to-day management plan, and to the need for the establishment of thesauri to provide standardisation and control in data entry.

The workshop included extensive hands-on training, and members of the IT staff of the division were also instructed in technical and administrative support.

\subsubsection{Workshop aims}

The aims of the workshop were to:

- familiarise the Bhutan team with the ARCHES database;

- discuss the entities available in the ARCHES database;

- discuss the concepts behind the ARCHES database (including thesauri);

- give hands-on training in the use of ARCHES

- decide if any elements of Bhutanese management practice were absent from ARCHES;

- propose customisations of ARCHES in order to facilitate management practice;

- familiarise IT staff with the technical aspects required to support ARCHES.

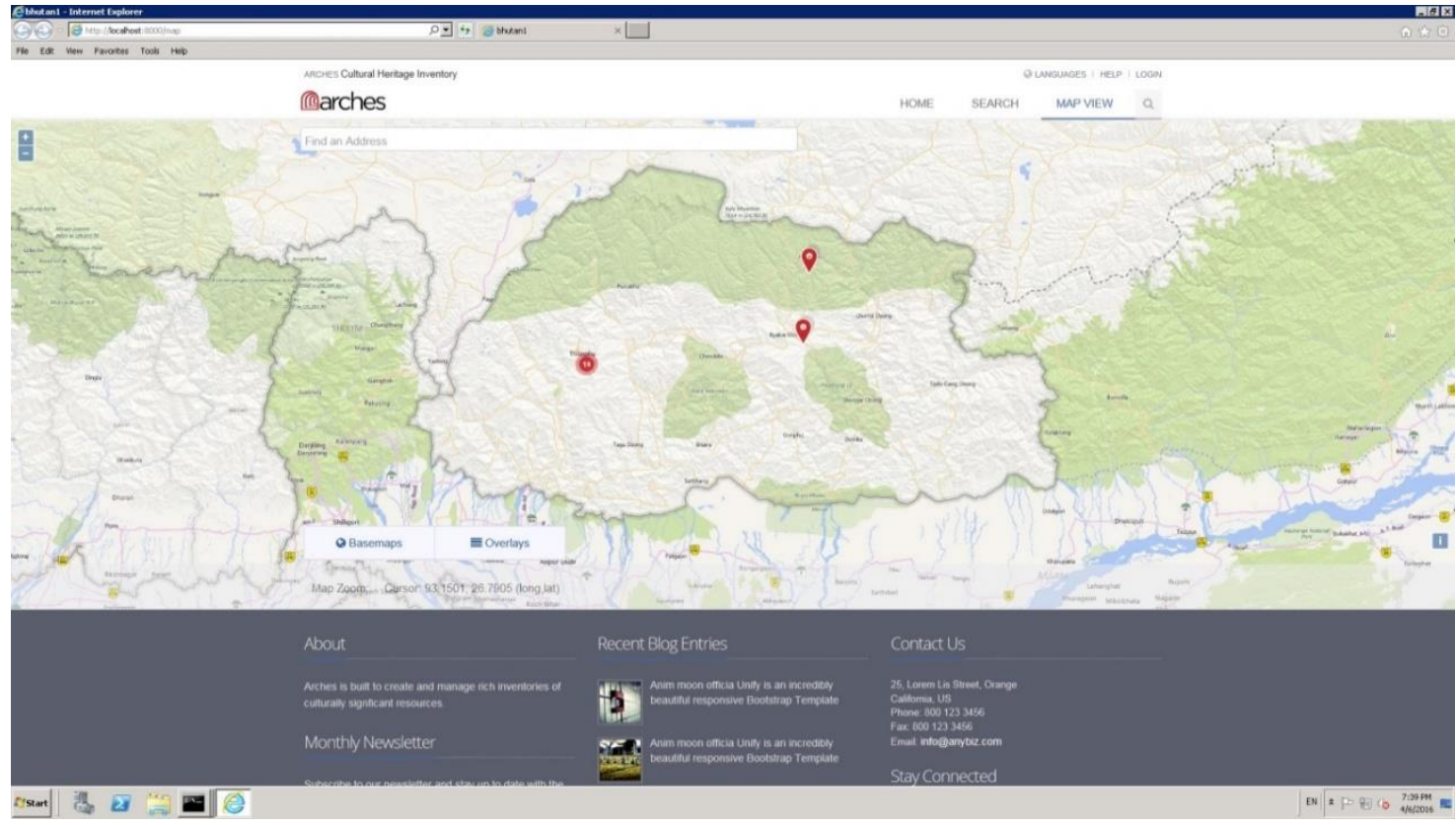

Figure 53. Front page of ARCHES for Bhutan.

\subsubsection{Workshop participants}

Workshop facilitator: Mr. Bryan Alvey (Cultural Heritage Information Consultants)

Bhutanese technical group:

1. Ms. Junko Mukai, Principal Heritage Architect, DCHS, DoC 
2. Mr. Yeshi Samdrup, Architect, DCHS, DoC

3. Mr. Sangay Kinga, Asst. Architect, DCHS, DoC

4. Ms. Sonam Zangmo, IT Officer, DCHS, DoC

5. Ms. Sushma Limbu, IT Officer, DCP, DoC

6. Mr. Rigzin Phuntsho, Assistant Research Officer, DCHS, DoC

7. Ms. Jambay Choden, Assistant Research Officer, DCHS, DoC

8. Mr. Nima Wangdi, Assistant Research Officer, DCHS, DoC

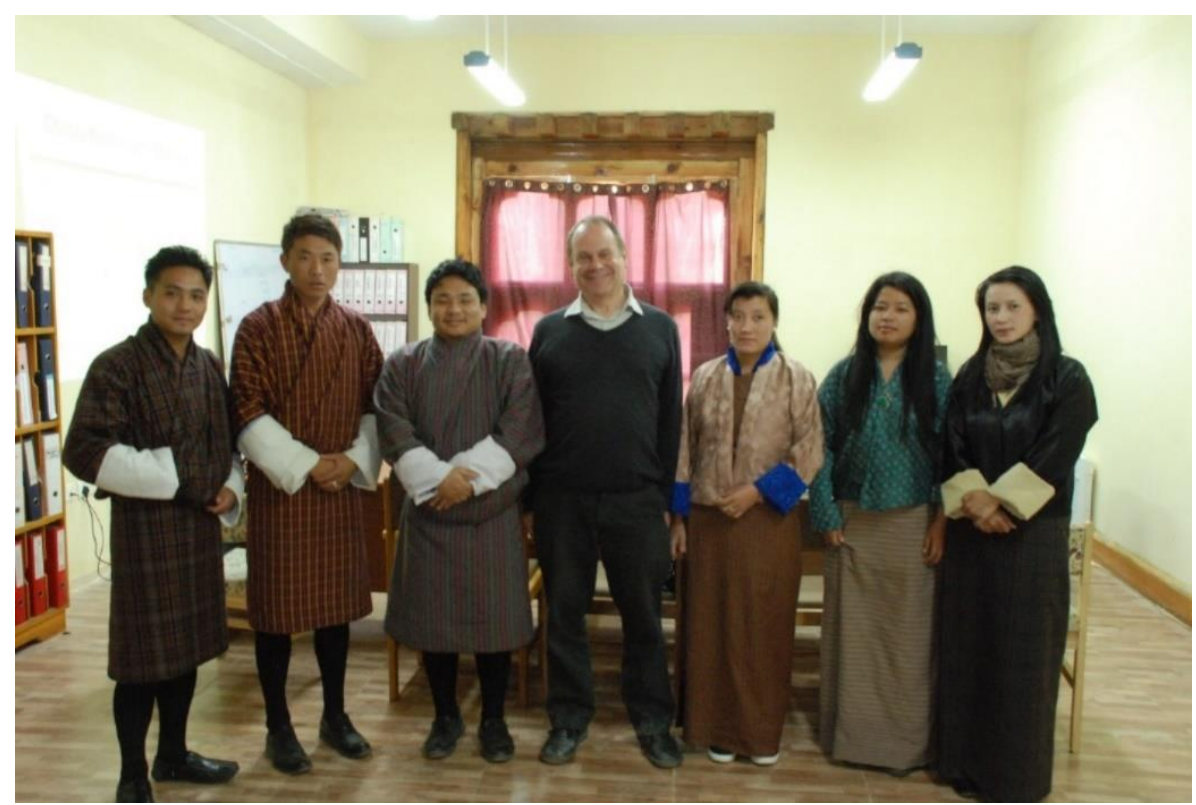

Figure 54. Participants at the February 2016 workshop on National Heritage Inventories, held at the Office of Department of Culture, Thimphu, Bhutan.

\subsubsection{Programme}

Session I: $11^{\text {th }}$ to $12^{\text {th }}$ February, 2016

$11^{\text {th }}$ February

09:30 AM: Welcome remarks by Ms. Nagtsho Dorji, Officiating Director, Department of Culture

09:40 AM: Introduction of participants

09:50 AM: Briefing of the programme by Mr. Bryan Alvey

10:15 AM to 16:0oPM: Workshop for the technical group on the following topics

- The Google Cloud

- The Google Cloud Console

- Establishing users on the Google Cloud

- Copying data to and from the Google Cloud

- The software that supports Arches (OSGeo4W/PostGreSQL,Django, Python)

$12^{\text {th }}$ February

o9:30 AM: Continuation of technical group workshop from the first day on following topics:

- How to Install Arches

- How to run Arches

- How Arches is organized on the Google server

- Settings.py and the Bing Key

- How the Thesaurus and data can be loaded into the system.

- How the Founders were loaded onto the system. 
Session II: $15^{\text {th }}$ to $17^{\text {th }}$ February

The session covered the following topics:

- Logging into the Cloud

- A general introduction to Arches

- Searching with Arches

- Overlays in Arches and Google maps

- An introduction to the things that Arches stores

- How to Add a Historic Resource

- How to Add a Monument

- How to Add a Historic Event

- How to Add an Activity (Conservations, restorations etc)

- How to Add an Information Resource

- How to Add a Person or Organisation

- The Resource Data Manager

- Building a Thesaurus

- Hierarchical and polyhierarchical relationships

\subsubsection{Outcomes}

\subsubsection{Familiarisation with the ARCHES database}

Staff and computer operators were shown a series of PowerPoint presentations ${ }^{22}$ which outlined the nature of each of the entities available within the ARCHES system: Historic Resource, Historic District (known as Monument in the system), Historic Event, Actor, Activity Resource and Information Resource.

The presentation described the methods by which data was entered into the system. These were reinforced later through hands-on training on the live database, which was installed on a virtual server in the Cloud.

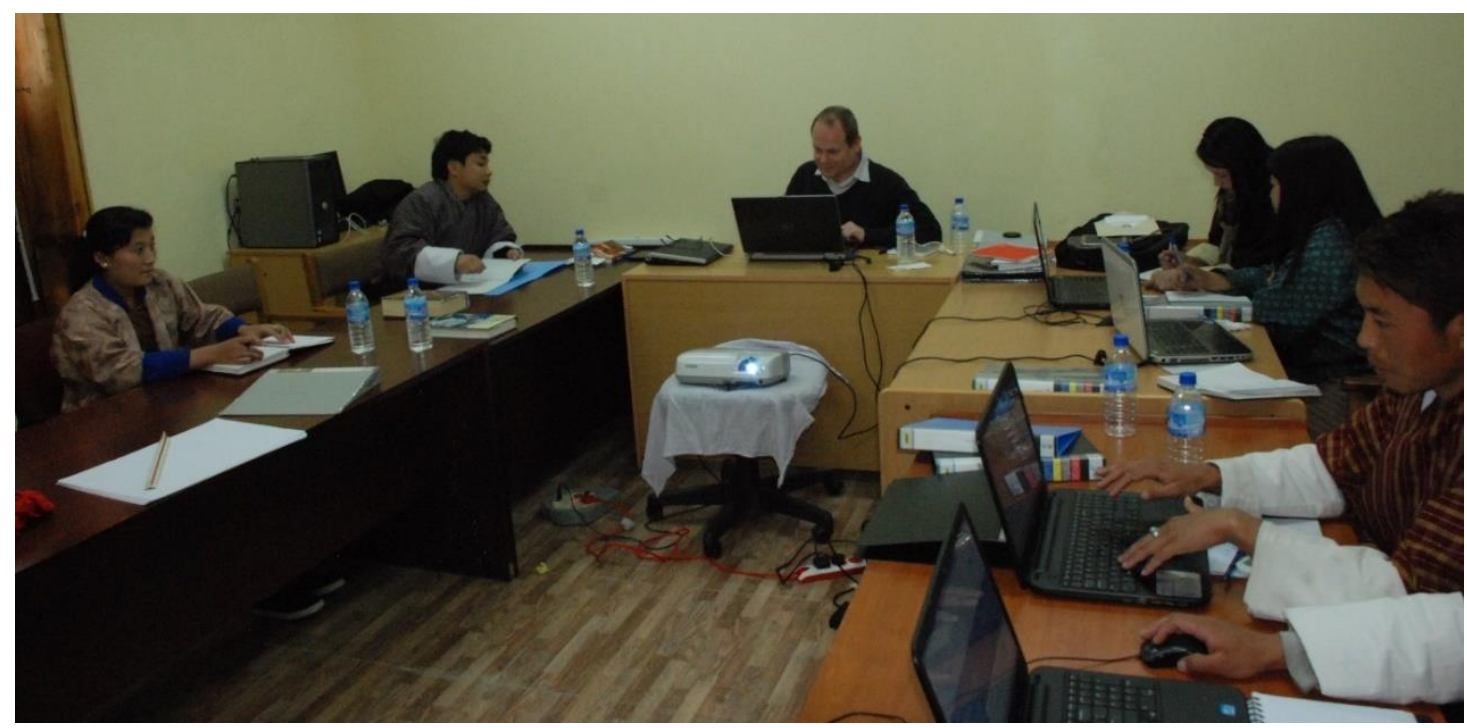

Figure 55. Presentation session at the Bhutan workshop.

Members of the Bhutanese staff compared the database fields for each of these entities to their existing management documentation, in order to understand how best ARCHES might fit with their current management practices. Most of the ARCHES elements matched extremely well with current Bhutanese recording practices, lacking only the elements that recorded the

${ }^{22}$ All the PowerPoints for the workshop, 17 in all, were provided to the DCHS staff for future reference. 
process of applications for conservation work, and the plot status of the historic resources (something perhaps unique to Bhutan).

\subsubsection{Discussion of the entities available in the ARCHES database}

Much of the workshop involved discussions as to how best to use the entities (resources) provided by ARCHES in their day-to-day management work. For example:

- how the Actor entity could be used to store information about the founders of the religious monuments;

- how the Historic Resource entity could be used to store information about religious buildings and Dzongs;

- how the Historic District entity could be used to store information about cultural sites.
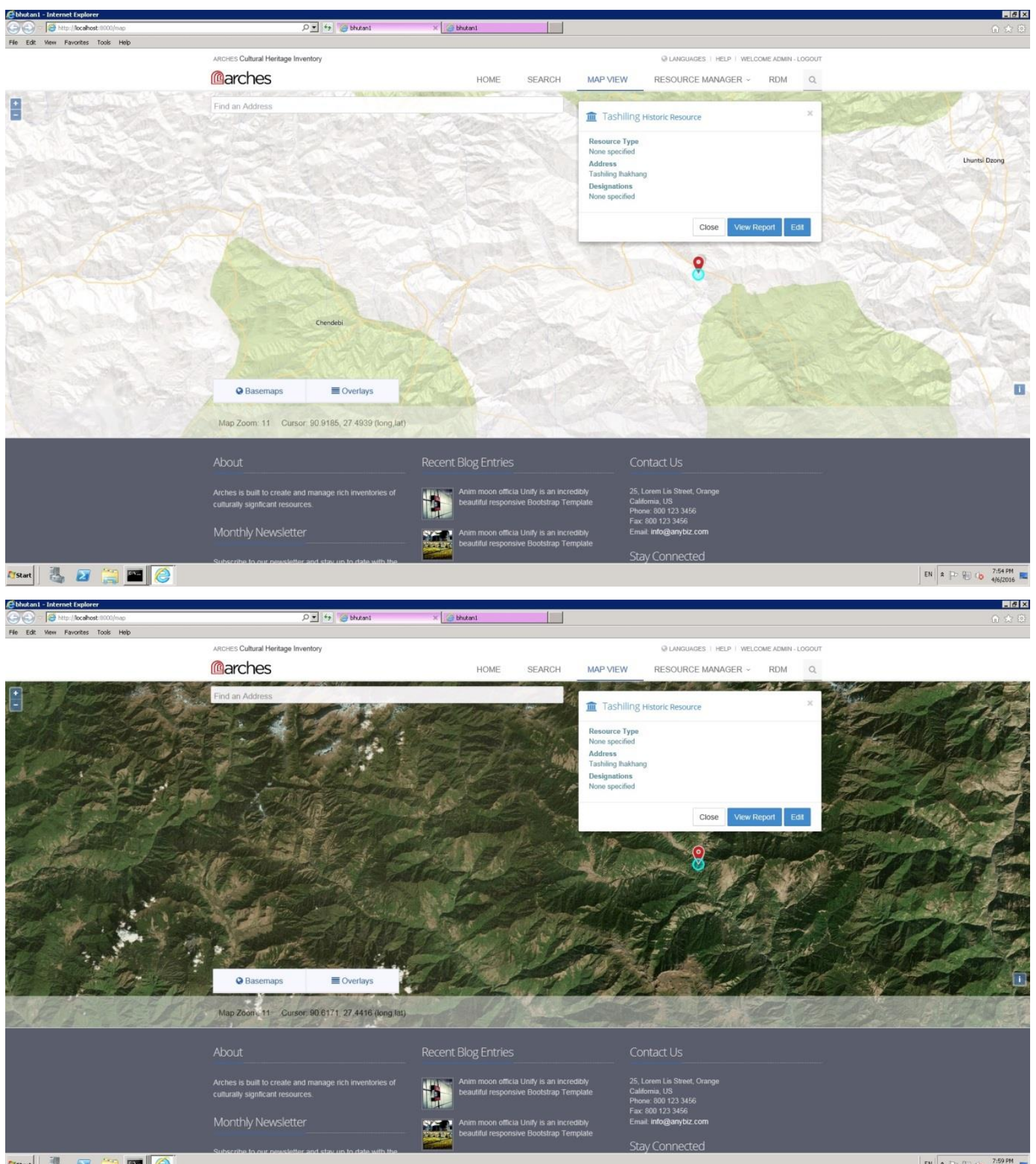

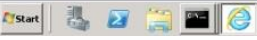

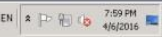

Figure 56. Entering data into ARCHES for an historic resource in Bhutan, displayed against different geographic backgrounds. 


\subsubsection{Discussion regarding the concepts behind the ARCHES database (including thesauri)}

The PowerPoint presentations covered every field, of every entity, in the ARCHES database. The Bhutanese staff were able to see how their own material might be fed into them. Many of these fields are controlled by dropdown lists - using controlled vocabularies holding the standard terms allowed for entries.

This led onto a discussion about the importance of thesauri of agreed terms, which would be fundamental to the Bhutan inventory. These thesauri are held in ARCHES through the Reference Data Manager, and the users were given a comprehensive overview of this area of the ARCHES system, using both PowerPoint presentations and demonstrations from the live system.

The importance of thesauri was discussed: how thesauri are used to provide standardised input to improve the integrity of the database; how thesauri are best compiled before the database is used on a day-to-day basis; how a comprehensive thesaurus can provide a richer resource for the user.

Another issue was the names for cultural periods: it was recognised that there was a need for more precise distinctions; for example, more than simply the 'Medieval' period. However, decisions to redefine or sub-divide periods require a political decision to be changed: this is an area that will need to be explored in the future.

The Bhutanese team agreed that one of their members would act as a conduit for new thesaurus terms: she will be responsible for entering new terms into the ARCHES system, once these have been agreed by the management team. It was also agreed that adequate time would be devoted, by the Bhutanese team, to developing the controlled elements in ARCHES in order to populate the dropdown lists with terms relevant to Bhutan, before live data is entered.

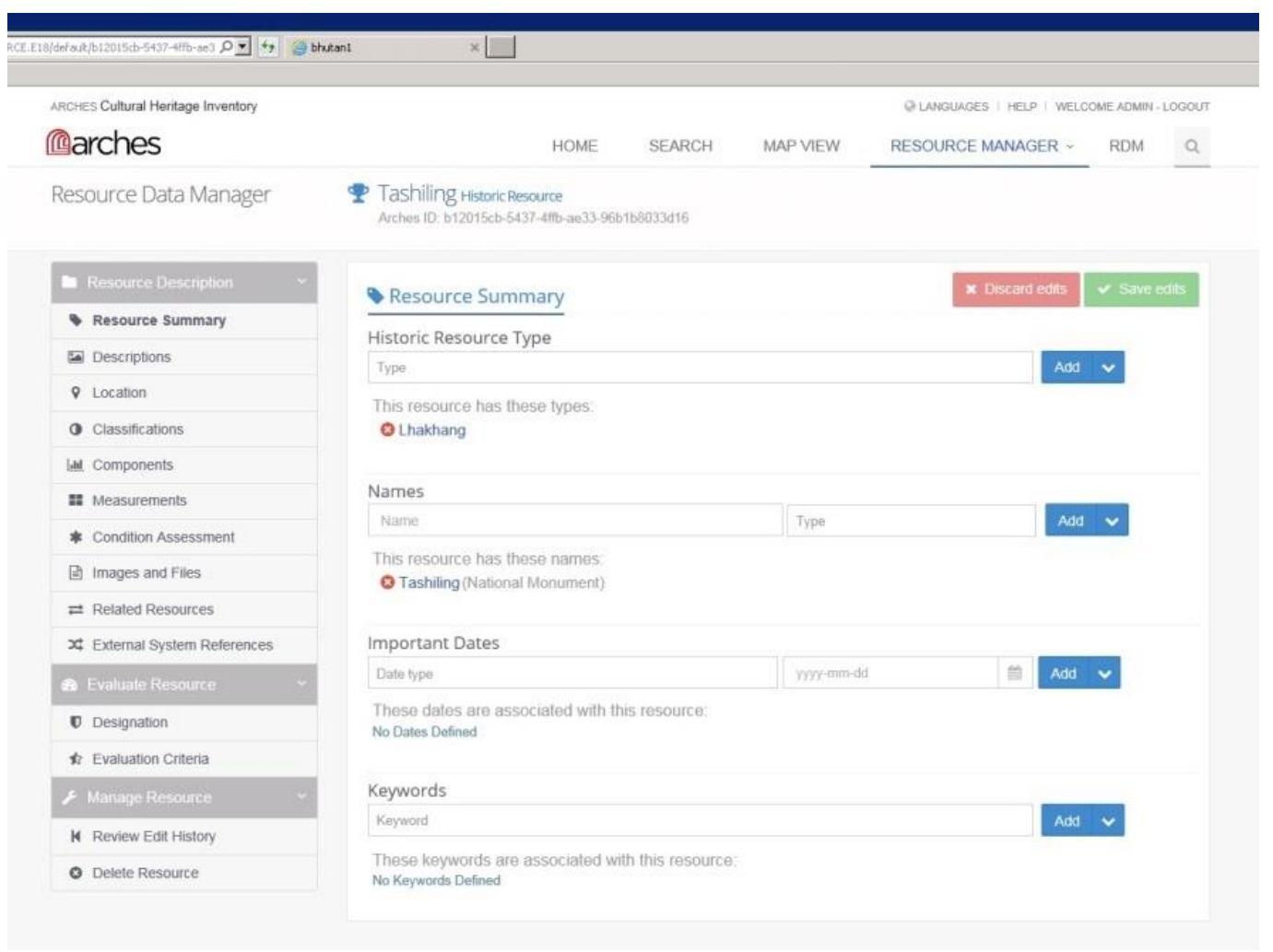

Figure 57. Displaying resource data in ARCHES. 


\subsubsection{Hands-on training in the use of ARCHES}

The Bhutanese staff members were given hands-on training in the second half of the workshop, entering a number of resources, then editing and deleting them, until the users were confident in using forms in ARCHES for entering resources.

The facilitator returned a week after the workshop to answer any further questions from the Bhutanese operators that had arisen through day-to-day data entry.
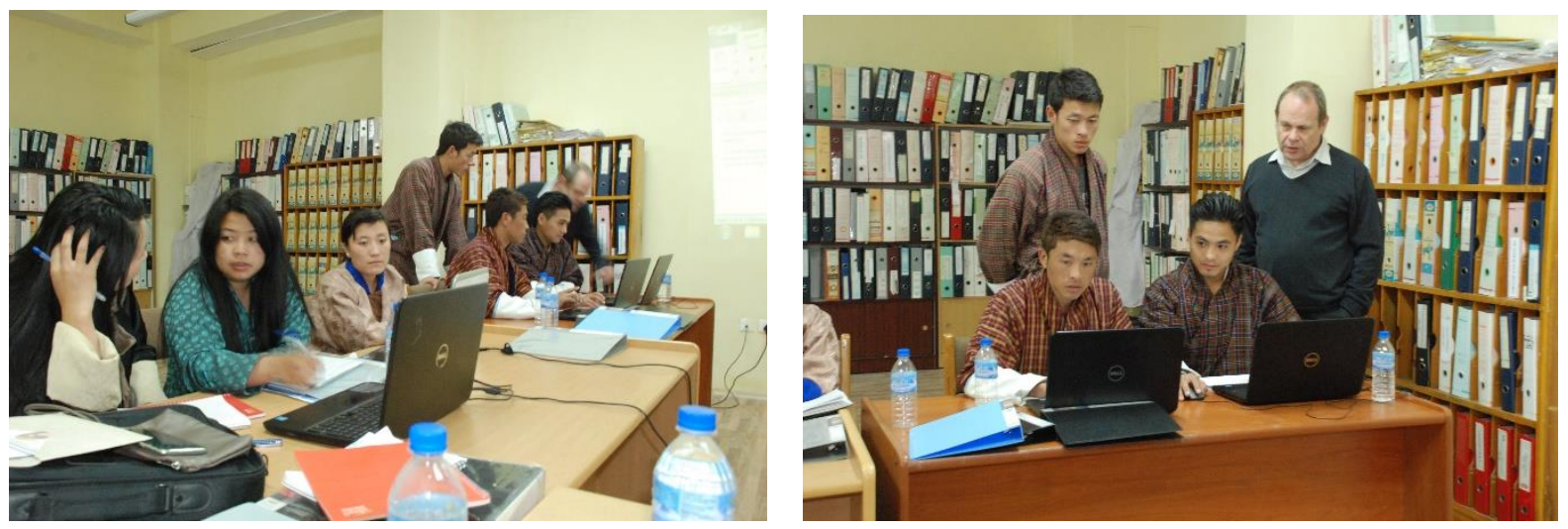

Figure 58. Hands-on training and discussion.

\subsubsection{Deciding if any elements of Bhutanese management practice were absent from ARCHES}

All through the workshop, the Bhutanese assessed the elements offered by ARCHES and compared them with their current recording systems. The facilitator encouraged frequent interruptions throughout the workshop, and many discussions took place as to which resources in ARCHES might best be used to hold the information needed by the Bhutanese. During this process, the Bhutanese were able to establish which elements were absent from the resources provided by ARCHES.

As Open Source Software, ARCHES can be customised without licensing costs, and can be configured and extended without restriction to meet the needs of individual users. By working through each of the elements of resources the Bhutanese staff were able to identify those items of information required in their day-to-day management activities that were not catered for in the standard ARCHES package. These primarily involved:

- information on applications for conservation and restoration from the owners of historic buildings;

- the plot status for the land on which historic buildings were located;

- some changes to labels and headings in the ARCHES forms.

\subsubsection{Proposals to customisations ARCHES in order to facilitate Bhutanese practices}

The Bhutanese team worked with the facilitator to see how best to incorporate these features into the ARCHES system. It was agreed that a new form should be added to the Historic Resource (and possibly the Historic District Resource), and that the location form be amended to incorporate land plot information. A rough outline for the design of these forms was proposed. It is considered essential that these additions be incorporated before the ARCHES application as early as possible. 


\subsubsection{Familiarisation of IT staff regarding the technical aspects required to support ARCHES}

The flexibility offered by ARCHES comes at a cost: currently ARCHES requires a familiarity with the operating system that lies behind Microsoft Windows, together with knowledge of PostgreSQL database and the Python programming language.

The technical staff were given an overview of the systems behind ARCHES and an introduction to the commands and skills needed to give basic technical and administrative support to the ARCHES system. The facilitator will continue to support the system until ARCHES is moved to the Bhutanese web server.

\subsubsection{Issues}

A number of issues arose during the workshop.

\subsubsection{MS Windows - Number of Users in the Cloud}

The number of simultaneous users on the Cloud is currently limited to two: this is an MS Windows limitation that allows a maximum of 2 users through the Remote Desktop Connection without further licences. An alternative means of accessing the Cloud securely is currently being investigated to enable up to six users on the system at any one time.

\subsubsection{ARCHES - Duplicate Key}

During the workshops, users were given a hands-on session in how to add records. During this, two users added a record simultaneously, and the two different records were given the same key (identifier). This may be because Arches may not be set up for multi-user entry by default. This is being investigated as it is clearly important for multiple-user entry.

\subsubsection{ARCHES - minor changes}

During the practical sessions, alternative labelling on some of the forms was requested by the Bhutanese staff. In addition, some minor changes were requested:

1) Change 'Assessment Summary' in components form to 'Related Features'.

2) Add a Measurement Description field to the Measurement form

3) Add new option to the External references field to limit access: Users want to be able to link to folders residing on the web server

4) Change Historic District thesauri

5) Change Overall condition to:
a. Wall Condition
b. Roof Condition
c. Timber Condition

6) Under Evaluation Criteria, change to: Registration or Designation; Change Eligibility \& Integrity fields to just one field \& label it 'Criteria'

7) DCHS to decide which elements will be given access to the general user: so need to alter 'report' to show the correct elements.

\subsubsection{Requested addition of a management tracking system}

One major addition to the ARCHES database was requested by the Bhutanese staff, in order to facilitate their day-to-day management work. Paper Application forms for works are routinely submitted by the managers/owners of monuments to request restoration work or new builds. As many as 5-10 of these may be received each week. These are assessed by the DCHS staff. A log is kept of decision-making, expenditure, materials requested, etc. The application form is a key document in current Bhutanese management practices. 
The Bhutanese staff proposed that the Historic Resource and Historic District entities within ARCHES could record this information. However, this would be a substantial addition to the system and not one that ARCHES, an inventory system, is perhaps best suited to deliver (see a similar issue with Nepal - Section 1). In addition, reporting facilities in ARCHES are not flexible enough to meet the sort of summary data reports that would meet their requirements.

Better standalone management tracking and workflow systems could be developed to accommodate these requirements, with reports specific to Bhutan's working practices. A summary report, reflecting final decisions regarding costs, work undertaken, outcomes, etc., could then be loaded in to the ARCHES inventory, to ensure that a record of past interventions to specific monuments was maintained. Developing such a system, however, would still be a substantive piece of work and not one that could be accommodated with the existing project.

\subsubsection{Conclusions}

By the conclusion of the workshop the Division for Conservation of Heritage Sites had:

i) a core group of people who were confident in entering data in to the ARCHES system;

ii) a management team that understood how to use live data and had established a way forward;

iii) minor amendments have been requested in order to create a system in keeping with their own management practices and terminologies;

iv) IT staff who are familiar with the ARCHES database operations, and have been trained in how to support the system;

v) communications have been established between the UCL facilitator and the Bhutanese team, should issues arise.

\subsection{Future work}

1) A short course in the use of Geographic Information Systems (GIS) is planned to be held in Bhutan in the summer of 2016.

2) Consideration of ways to develop a management flow system for the DCHS (see 6.5.6.4);

3) Dialogue with ICIMOD (Kathmandu, Nepal), who have worked on landscape mapping of Bhutan. There is a need to explore synergies between the existing works and the new Bhutan National Inventory of Heritage Sites;

4) Explore the potential synergies and collaborative benefits with the development of a Nepalese National Inventory system (see Section 1). 


\section{Complimentary Activities: Nepal National Inventory}

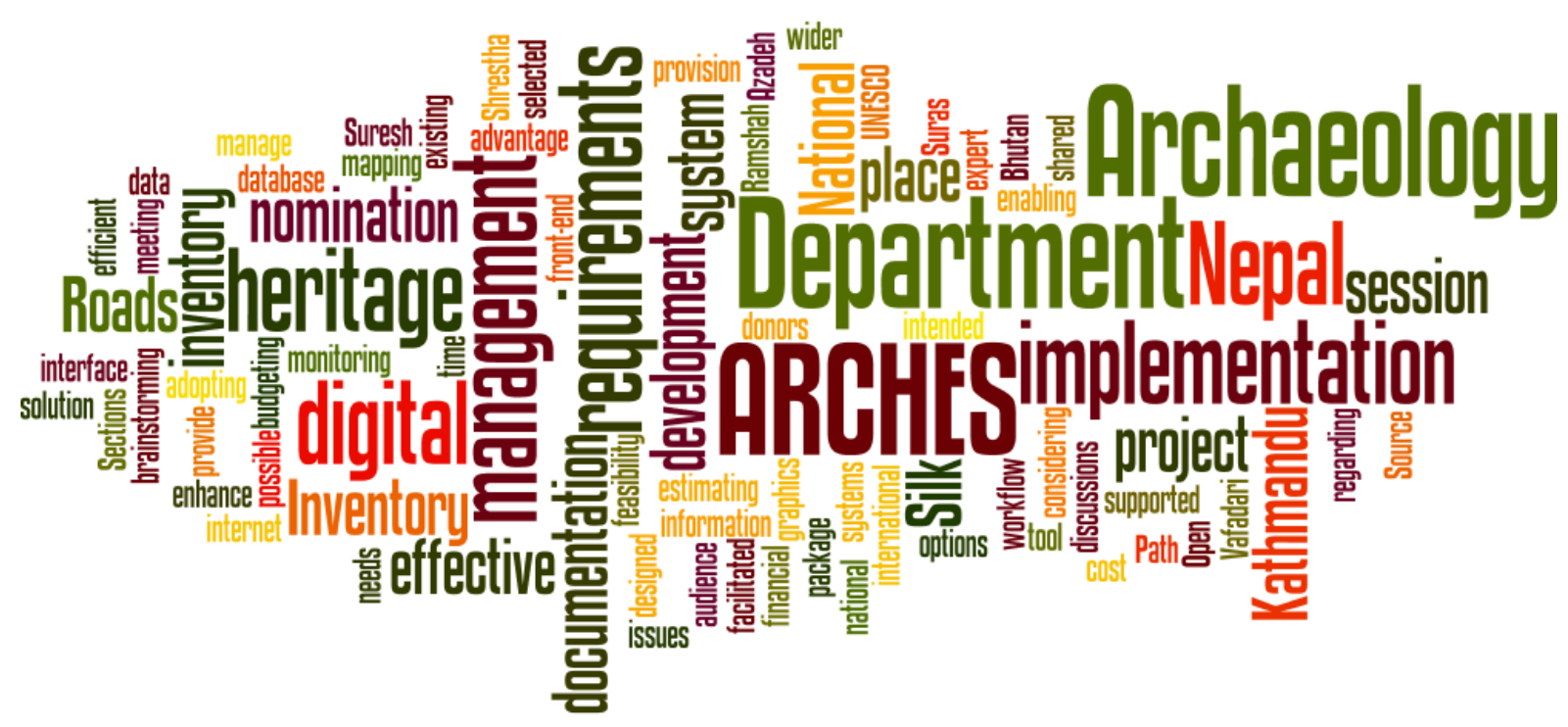

Nepal has been considering for some time the development of a digital National Inventory system. This has arisen, in part, through the requirements to enhance the existing documentation for the Silk Roads nomination project, including the provision of effective digital mapping and monitoring systems (see Sections 4.7.5 \& 5.5).

This led to a brainstorming session on the feasibility of adopting ARCHES as a heritage management database tool for the Department of Archaeology, Nepal. The meeting, which took place 25-26 August 2015 in the Department of Archaeology, Ramshah Path, Kathmandu, was organised by the Department of Archaeology and supported by the UNESCO Office in Kathmandu. The session, facilitated by Suresh Suras Shrestha, and with an international expert in the use of ARCHES, Ms Azadeh Vafadari, considered some of the options for the development of a National Inventory, including whether ARCHES would meet the national requirements.

ARCHES is a very effective heritage inventory package, with the considerable advantage of being Open Source, with a very useful graphics interface, and an efficient front-end enabling selected data to be shared with a wider audience on the internet. However, it is not designed to be a management workflow system (see the issues raised in its implementation in Bhutan Section 6.5.6.4); nor is it intended to manage financial information (donors, cost estimating, budgeting, etc.). As such, its implementation in Nepal would address the needs of a digital heritage inventory (and associated documentation for the Silk Roads nomination project), but it would not provide the solution to all of the management requirements of the Department of Archaeology. Further discussions will take place regarding its possible implementation. 


\section{Conclusion}

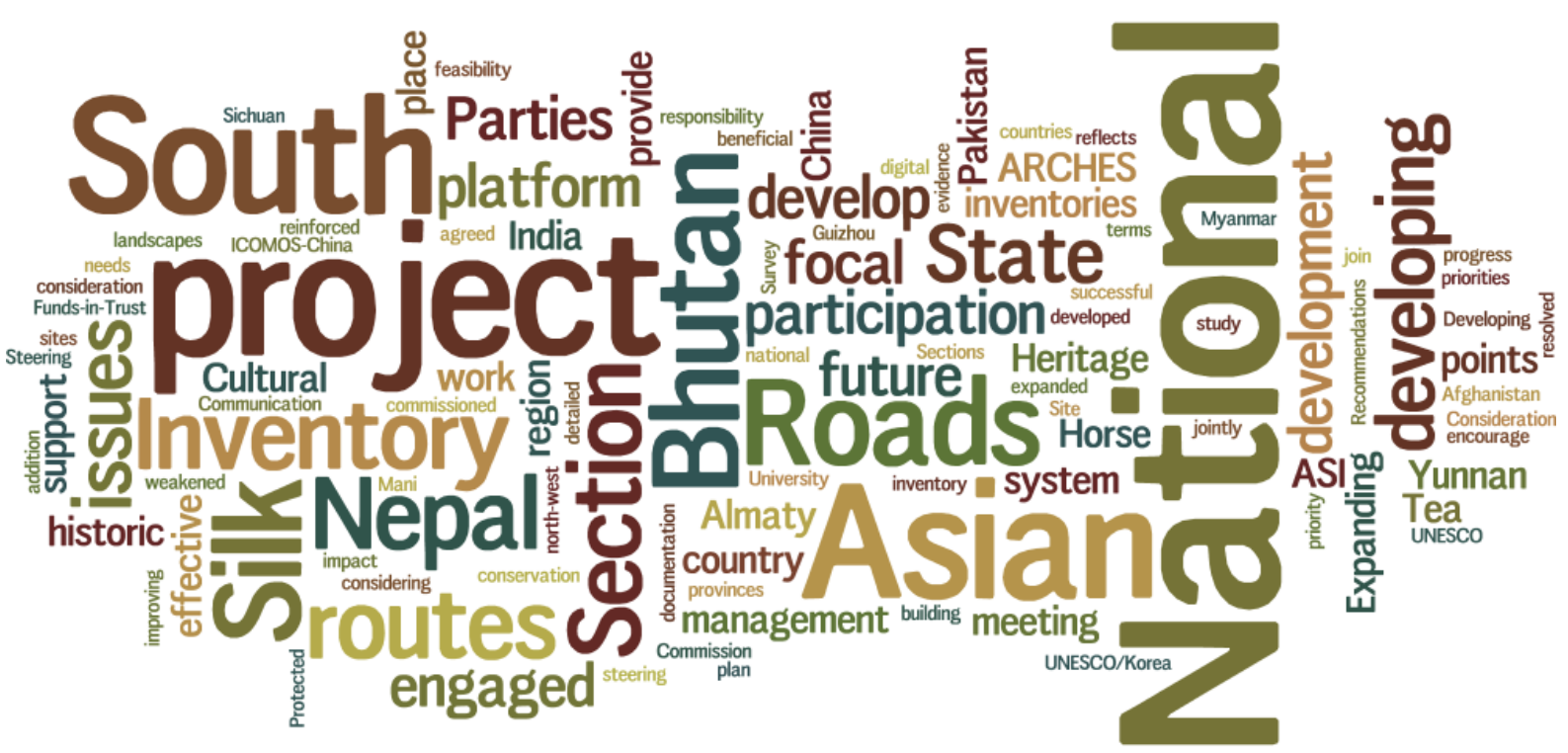

\subsection{Introduction}

$4^{\text {th }}$ Steering Silk Roads meeting in Almaty in 2015 (see section 4.8.4) reinforced the desire for the UNESCO/Korea Funds-in-Trust South Asian Silk Roads project to continue (Phase II), and to encourage Pakistan and other South Asian countries to join this nomination process.

There are a number of issues that need to be developed to push the South Asian project forward:

- Need for clear national focal points (8.2)

- Expanding the State Parties engaged in the South Asian project (8.3)

- Developing National inventories in Bhutan \& Nepal (8.4)

In addition, see the Recommendations for the South Asian Silk Roads (2014) (reproduced in Appendix 2 of this report), which reflects these issues and sets out other priorities for support and development.

\subsection{National focal points \& progress}

Communication between State Parties is vital to the successful development of this project.

The participation of India seems to have weakened since the retirement of Dr B.R. Mani, Assistant Director General of the Archaeological Survey of India (ASI). It was not clear who had taken on the responsibility for the South Asian Silk Roads within the ASI and this needed to be resolved in order to develop future participation.

The participation of China in the project appears to lack official support. Whilst dialogue had taken place, the National Commission of UNESCO China and the State Administration of Cultural Heritage are not yet engaged in the project. However, the Tea \& Horse routes were listed as a 'the Major Historical and Cultural Site Protected at the National Level' in 2013, jointly nominated by three provinces (Yunnan, Sichuan and Guizhou). In late 2015 Prof Lyu 
(Lu) Zhou from Tsinghua University (Director of National Heritage Centre and Vice-president of ICOMOS-China), has been commissioned to undertake a feasibility study for a management plan for the Tea \& Horse routes in Yunnan Province. Nevertheless, it is important that a clear focal point is established for future development.

In Nepal, the devastating impact of the earthquake in April 2015 has necessarily diverted attention from the Silk Roads project. The priority, in terms of developing the National Inventory (see Section 1), and improving the documentation of sites and landscapes along the routes (see Sections 4.7.5 \& 5.5), will gradually come back on stream.

In Bhutan, work is now taking place to develop the National Inventory (see Section 1). This will provide a platform for Bhutan to consider the pre-1 $17^{\text {th }}$ century historic landscape of the country, which will lead, in the future, to a more detailed consideration of the evidence for historic routes through the country.

\subsection{Expanding the State Parties engaged in the South Asian project}

It was agreed at the Almaty Silk Roads steering group meeting that the South Asian project could be expanded to include Bangladesh, Pakistan, and Myanmar, and to develop closer ties with Afghanistan regarding routes in the north-west of the region.

Consideration needs to be given as to how best to build partnerships across the region.

\subsection{National inventories in Bhutan \& Nepal}

Bhutan is currently developing their National Inventory using the ARCHES system (see Section 1). There remain a few of issues regarding its implementation (see Section 6.6).

Nepal is also considering developing a digital National Inventory and is also exploring the potential use of the ARCHES system. This may well provide an effective platform for the inventory, but will not necessarily cover other issues of management conservation work (see Section 1). Nevertheless, developing an effective platform between Bhutan and Nepal to share experiences and approaches to National Inventory building could be very beneficial. 


\section{Acknowledgments}

Above all, thanks go to the Korean Funds-in-Trust for supporting the South Asia project, and to the UNESCO World Heritage Centre, Asia and Pacific Unit, who co-ordinated the efforts. In particular, thanks go to Prof Roland Lin (UNESCO World Heritage Centre: Asia and Pacific Unit) for his enthusiasm and direction.

A great deal of thanks for implementing the project goes to the staff of the UNESCO New Delhi ${ }^{23}$ and UNESCO Kathmandu offices ${ }^{24}$. The staff of these offices, especially Moe Chiba (UNESCO New Delhi) and Nipuna Shrestha (UNESCO Kathmandu), were central to making the project such as success. Thanks also to Christian Manhart, Head of Office UNESCO Kathmandu, for facilitating many of the activities.

As with any such project, the greatest thanks actually go to the people working on the ground in the various countries. Particular thanks for the roles in coordinating activities, or taking a lead in activities, goes to:

Bhutan: the staff of the DCHS, in particular Mr. Dorjee Tshering, Mrs. Nagtsho Dorji (Head Architect), Mr. Choening Dorji (Senior Architect), Mr. Yeshi Samdrup (Architect, with special responsibility for World Heritage and Silk Roads), Ms. Junko Mukai (Principal Heritage Architect), Mr. Karma Tenzin (Architect, with special responsibility for archaeology), Mr. Sangay Kinga (Assistant Architect), Ms. Sonam Zangmo (IT Officer), Ms. Sushma Limbu (IT Officer), and Mr. Rigzin Phuntsho, Ms. Jambay Choden and Mr. Nima Wangdi (Assistant Research Officers).

China: Prof Lyu (Lu) Zhou from Tsinghua University Director of National Heritage Centre, Tsinghua University and Vice-president of ICOMOS-China.

India: Dr B.R. Mani (Additional Director General, Archaeological Survey of India) and Dr Shikha Jain (Secretary, Advisory Committee on World Heritage Matters).

Nepal: Mr Bhesh Narayan Dahal (Director General, Department of Archaeology), Mr Suresh Suras Shrestha (Chief of Monument Conservation Section, Department of Archaeology; Focal Point for Silk Roads activities in Nepal), Mr Sukra Sagar Shrestha (National expert, Silk Roads activities in Nepal), Mr Bharat Rawat (Deputy Director General, Department of Archaeology), Mr Debendra Bhattarai (Archaeological Officer, Focal Point for Cultural World Heritage Properties in Nepal, Department of Archaeology), Mr Ram Bahadur Kunwar (Chief Archaeological Officer, Chief of Archaeology Section, Department of Archaeology), Mr Bishwo Prakash Pandi (Secretary-General, Nepal National Commission for UNESCO), Prof Susanne von der Heide (Director, HimalAsia Foundation), Prof Dr Ramesh Dhungel (Centre for Nepalese and Asian Studies, Tribhuvan University), and Mr Kai Weise (ICOMOS Nepal).

Considerable thanks go to the Getty Conservation Institute and the World Monuments Fund for their development of the ARCHES (http://archesproject.org/) heritage inventory system, and the open source software development by Farallon Geographics, Inc ${ }^{25}$. In particular, we would like to thank Alison Dalgity, Manager of the Web and Digital Initiatives Department at the Getty Conservation Institute, and Dennis Wuthrich, CEO at Farallon Geographics.

${ }^{23} \mathrm{http://www.unesco.org/new/en/newdelhi}$

${ }^{24}$ http://www.unesco.org/new/en/kathmandu/

${ }^{25}$ See http://fargeo.com/cultural-resources/ 
Special thanks go to Bryan Alvey (Cultural Heritage Information Consultants) for his extensive work customising the ARCHES database for Bhutan, and his efforts in implementing this through the workshops in Bhutan. This work was considerably assisted by Adam Cox.

The excellent work of Dr Adi Keinan-Schoonbaert and Professor Andrew Bevan (Institute of Archaeology, UCL) in assisting with the documentation workshop in Bhutan, and their clear and sound advice of strategies for both digital documentation and Geographic Information Systems.

Grateful thanks also to Dr Gai Jorayev (UCL) for his assistance in designing and printing this report.

In Bhutan, considerable thanks to the staff of the Division for Conservation of Heritage Sites (DCHS), who made our stay so welcome. Particular thanks go to Yeshi Samdrup for organising the workshops and his invaluable contribution.

Personally, I would like to thank the Korean-Funds-in-Trust, who generously supported the UCL participation in this programme, and Moe Chiba, Section Chief \& Programme Specialist for Culture, UNESCO Delhi, and Dr Roland Lin Chih-Hung, from the Asia \& Pacific Unit, UNESCO World Heritage Centre Paris, for organising our participation in this project.

Tim Williams, Institute of Archaeology, London, March 2016 


\section{References}

Akasoy, A, Burnett, C, \& Yoeli-Tlalim, R (eds) (2011) Islam and Tibet Interactions along the Musk Routes. Farnham: Ashgate

Appadurai, A (1986) Introduction: Commodities and the Politics of Value, in Appadurai, A (ed) The Social Life of Things: Commodities in Cultural Perspective 3-63. Cambridge: Cambridge University Press

Carlisle, P, Avramides, Y, Dalgity, A, \& Myers, D (2014) The Arches Heritage Inventory and Management System: a standards-based approach to the management of cultural heritage information. http://www.getty.edu/conservation/our_projects/field_projects/arches/Carlisle_Dalgity_et_al _2014_Arches_Heritage_CIDOC.pdf

Choden, K \& Roder, D C (eds) (2012) Ogyen Choling: a manor in central Bhutan. Thimphu: Riyang Books Cleere, H (2006) Serial Nomination of the Silk Roads to the World Heritage List: A Concept Paper.

Elverskog, J (2010) Buddhism and Islam on the Silk Road. Philadelphia: University of Pennsylvania Press

Fisher, J F (1992) Trans-Himalayan Traders: Economy, Society and Culture in North-west Nepal. Los Angeles: University of California Press

Fogelin, L (2005) Archaeology of early Buddhism. Lanham, MD: AltaMira Press

Hamashita, T (2011) The Lidai Baoan and the Ryukyu Maritime Tributary Trade Network with China and Southeast Asia, the Fourteenth to Seventeenth Centuries, in Tagliacozzo, E \& Chang, W-C (eds) Chinese Circulations: Capital, Commodities, and Networks in Southeast Asia 107-129. Durham, North Carolina: Duke University Press

ICOMOS (2002) Desk study on the Asia Region. ICOMOS

ICOMOS (2004) The World Heritage List: Filling the Gaps - An Action Plan for the Future. Paris: ICOMOS

Myers, D, Avramides, Y, \& Dalgity, A (2013) Changing the Heritage Inventory Paradigm: The Arches Open Source System, Conservation perspectives.The Getty Conservation Institute Newsletter 28 (2)

Myers, D, Dalgity, A, Avramides, Y, \& Wuthrich, D (2012) Arches: An Open Source GIS for the Inventory and Management of Immovable Cultural Heritage, Progress in Cultural Heritage Preservation: 4th International Conference. EuroMed Conference 2012, Lemessos, Cyprus, October 29- November 3, 2012 817-824.

Neelis, J (2011) Early Buddhist Transmission and Trade Networks: Mobility and Exchange within and beyond the Northwestern Borderlands of South Asia. Leiden: Brill

Ong, A (1999) Flexible citizenship: the cultural logics of transnationality. Durham, N.C.: Duke University Press

Phuntsho, K (2013) The history of Bhutan. Noida: Randon House India

Rizvi, J (2000) Trans-Himalayan Caravans: Merchant Princes and Peasant Traders in Ladakh. OUP India

Tagliacozzo, E \& Chang, W-C (eds) (2011) Chinese Circulations: Capital, Commodities, and Networks in Southeast Asia. Durham, North Carolina: Duke University Press

Tong, T (2013) The Silk Roads of the Northern Tibetan Plateau During the Early Middle Ages (from the Han to Tang Dynasty). Oxford: Archaeopress

UNESCO (1988) The significance of the Silk Roads in the history of human civilizations. Integral Study of the Silk Roads: Roads of Dialogue. Independent Seminar, Osaka, Japan, 24-26 October

UNESCO (2007) A Concept for the Serial Nomination of the Silk Roads in Central Asia and China to the World Heritage List. Unpublished report. Dushanbe: UNESCO

UNESCO (2008) A Concept for the Serial Nomination of the Silk Roads in Central Asia and China to the World Heritage List (updated text after the Consultation meeting in Xi'an (China), June 2008). Unpublished report. Xi'an: UNESCO

Williams, T (2014) Silk Roads: an ICOMOS thematic study. Charenton-le-Pont: ICOMOS

Wong, D C \& Heldt, G (2014) China and Beyond in the Mediaeval Period: Cultural Crossings and InterRegional Connections. Amherst, NY: Cambria Press

Wriggins, S H (2004) The Silk Road journey with Xuanzang. Oxford: Westview Press

Zhaoming, X (2014) The Hepu Han tombs and the maritime Silk Road of the Han Dynasty, Antiquity 88 (342): 1229-1243 


\section{Appendix 1: South Asian Nomination Strategy}

\section{South Asian Silk Roads:}

\section{Serial and Transnational World Heritage Nomination Strategy}

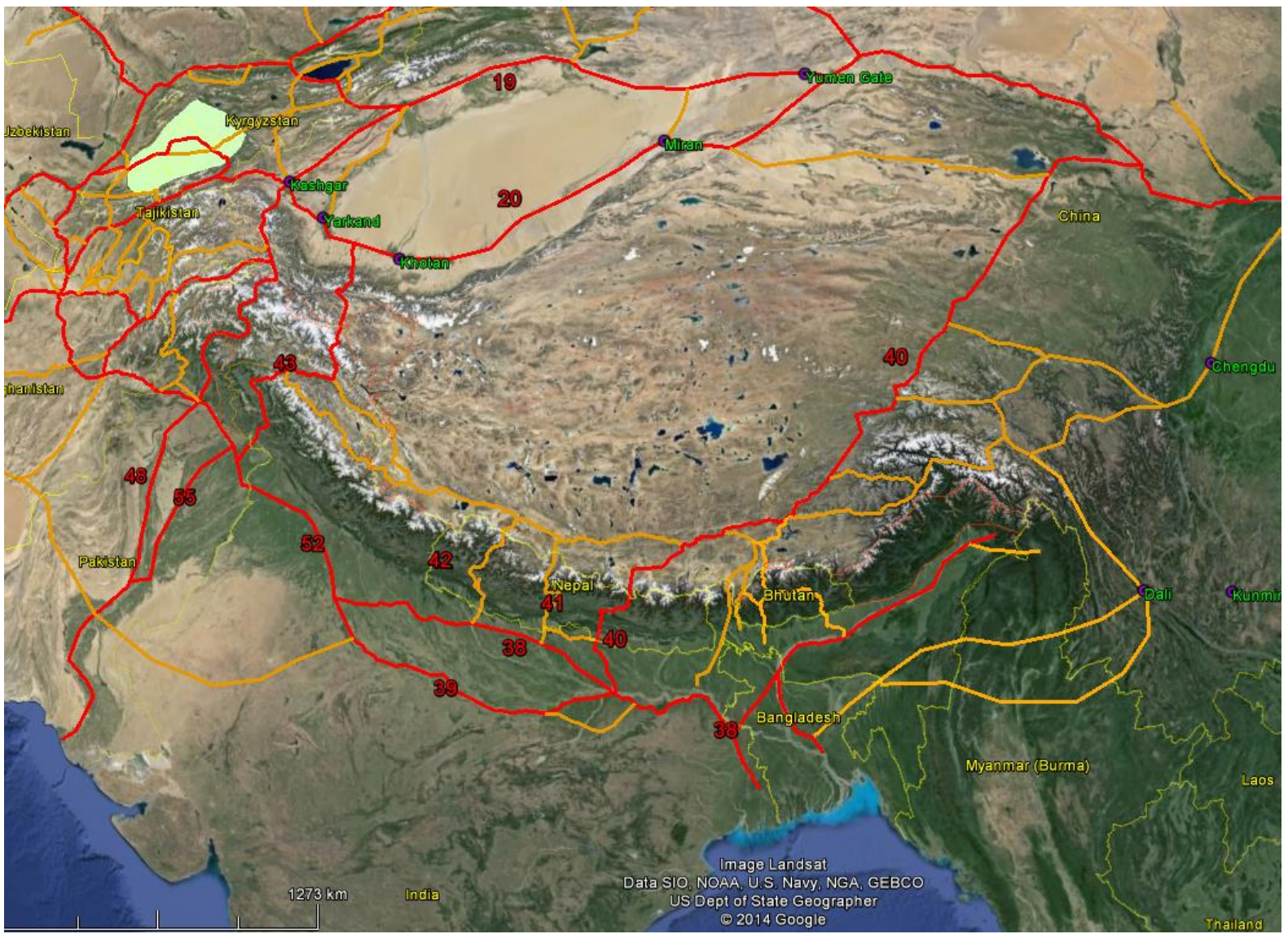

\section{Tim Williams}

\section{Institute of Archaeology, UCL}

Prepared within the framework of the UNESCO/Korean Funds-in-Trust project "Support for the preparation for the World Heritage Serial Nomination of the Silk Roads in South Asia", and with the support of the UNESCO World Heritage Centre and UNESCO Offices in Kathmandu and in New Delhi

\section{Version 3}

December 2014 


\section{Content}

1 Introduction.........................93

2 South Asian nomination strategy: general issues ..............................994

2.1 INTRODUCTION.......................... 94

2.2 SELECTION OF CORRIDORS.......... 95

2.3 TENTATIVE LISTS ....................... 95

2.4 NATIONAL INVENTORIES AND

CONTINUING RESEARCH......................... 96

2.5 SITE SELECTION WITHIN

CORRIDORS .......................................... 96

2.6 LINKING WITH EXISTING WORLD

HERITAGE SITES...................................... 96

2.7 PROTECTION AND MANAGEMENT 96

3 Nomination strategy.................997

3.1 ROUTES FROM THE TIBETAN Plateau to the Gangetic Plain VIa NEPAL 97

3.2 SOUTHERN TAKLAMAKAN TO

NORTH-WEST INDIA (AND BEYOND) ......... 99

3.3 SOUTHWEST SILK ROADS: TEA AND HORSE 99

3.4 THE NORTHWEST FRONTIER ROUTES TO CENTRAL ASIA 100

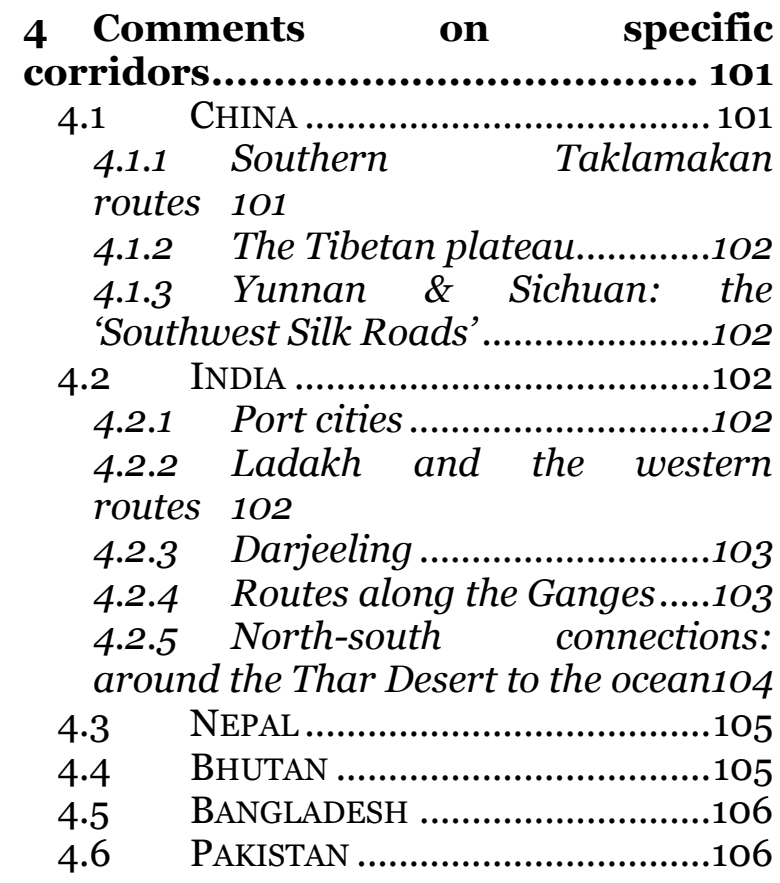

References 107

\section{List of Figures}

Figure 1. The corridors identified in the ICOMOS Thematic Study (Williams 2014)......................................................94 Figure 2. The South Asian region and the principle route identified in the original Silk Roads Thematic Study.... 95 Figure 3. Sites along the Tibetan Plateau and the three corridors through Nepal: the easternmost Kathmandu Valley (Corridor 40), the central (mid-western Nepal) route through Lo Manthang and Lumbini (Corridor 41) and the westernmost route including Jumla and Surkhet (Corridor 42)........................................................98 Figure 4. The lower Gangetic Plain...........98 Figure 5. Southern Taklamakan to northwest India (and beyond).............................99 Figure 6. Beginning to examine the routes between Yunan and Sichuan (right), through Bhutan and Myanmar, to India and Bangladesh.............................................100 Figure 7. The northwest frontier routes to Central Asia. .101 Figure 8. The Southern Taklamakan corridor...................................................101 Figure 9. Through the high Karakoram from the southern Taklamakan through Srinagar, Leh and Sangju Pass to the Gangetic Plain. ........................................ 103 Figure 10. The Indo-Gangetic Plain: the fertile plain of the Ganges and Indus river systems.................................................. 104 Figure 11. The corridors through the Gangetic Plain: the wide fertile river system of the Ganges enabled sites to develop over a broad area and there were multiple routes across this landscape. At present two corridors (Corridors 38 and 39) have been defined, encompassing the main urban developments and monuments, but a single wider corridor probably may be more appropriate, linking into the network of north-south routes across the Himalayas............................................... 104 Figure 12. The routes (not yet mapped) south-westward to the Ocean................... 105 Figure 13. The Indus Valley...................... 106 


\section{Introduction}

This paper reviews existing data and suggests possible approaches for the South Asian region to the serial trans-boundary Silk Roads World Heritage nomination process. A first draft of this paper was prepared in advance of the sub-regional meeting held in Kathmandu, Nepal, 23-24 September 2014, attended by the representatives and experts from the four South Asian countries of Bhutan, China, India and Nepal, together with UNESCO representatives and UNESCO international experts. This version has been updated based on the discussions held at that meeting.

The State parties, especially China, India and Nepal, expressed an in principle interest in collaborating. However, the discussion did not allow them to reach consensus on exact routes to work on. State parties nonetheless agreed on an Action Plan ${ }^{26}$ and timeframe, the broad stages being:

- May 2015 Agree upon the first South Asian priority transnational Silk Roads heritage corridor(s); Fourth meeting of the Silk Roads Serial Transnational World Heritage Nomination Intergovernmental Coordinating Committee;

- August/Sept 2015 1st meeting of the South Asian Silk Roads Working Group (identification of the content of the definition for the inscription; updating the World Heritage Tentative List of Silk Roads by the State Parties);

- December 2015 2nd meeting of the South Asian Silk Roads Working Group Memorandum for preparation of serial and transnational nomination of South Asian Silk Roads sites for the UNESCO World Heritage list;

- December 2016 3rd meeting of the South Asian Silk Roads Working Group Harmonization of the preparation process of the South Asian Silk Roads corridor nomination (approval of the content of the dossier);

- By 1 February 2017 Official Submission of updated Silk Roads World Heritage Tentative Lists in the participating State Parties;

- September 2017 Submission of the South Asian Silk Roads draft nomination dossier to World Heritage Centre for the preliminary review;

- January 2018 Submission of the final dossiers to World Heritage Centre.

For a background to the Silk Roads strategy, see the Silk Roads: an ICOMOS thematic study (Williams 2014); this is also available digitally ${ }^{27}$. This established the approach of using 'corridors of movement' to conceptualise the complexity of Silk Roads archaeology and heritage, and to create a practical modular framework for the selection of corridors to form trans-boundary nomination projects. It also identified a number of likely corridors for consideration which extended into the South Asia region (Figure 1), although it did not comprehensively cover it.

\footnotetext{
${ }^{26}$ Kathmandu Action Plan of the first South Asian priority transnational heritage corridor(s) agreed at Sub-regional Workshop on the Nomination Strategy for the South Asian Silk Roads, Kathmandu, Nepal, 23-24 September 2014 27

http://www.icomos.org/images/mediatheque/ICOMOS WHThematicStudy SilkRoads final lv 20 1406.pdf and from UCL discovery at http://discovery.ucl.ac.uk/135666o/ 


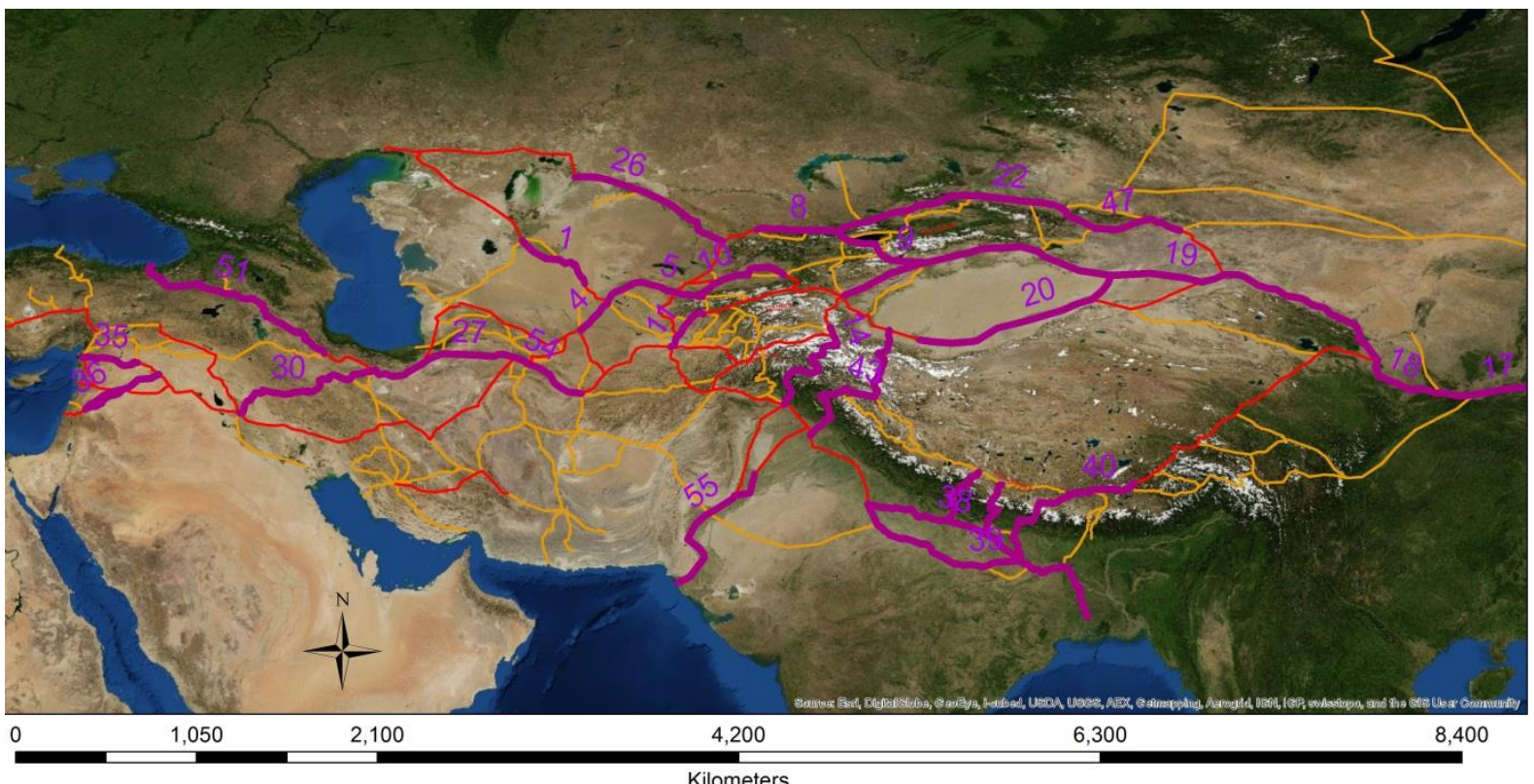

Figure 1. The corridors identified in the ICOMOS Thematic Study (Williams 2014 ).

The Thematic Study also includes the Concept Statement for the Silk Roads, which sets out the broader vision of the project and establishes its chronological framework and key attributes.

\section{South Asian nomination strategy: general issues}

\subsection{Introduction}

A number of vitally important trans-Himalayan routes connected western China (Yunnan, Sichuan and Xingjian) and Central Asia, via the Tibetan plateau, to the Indian subcontinent (Figure 2). These routes were fundamental to the development of the region (Fisher 1992; Rizvi 2000; Tong 2013). These broadly north-south routes connected with largely east-west routes, such as those along the southern Taklamakan Desert (Corridor $\mathbf{2 0}^{28}$ ), and those along the Gangetic Plain (Corridors 38 \& 39).

The trade goods passing along these various routes comprised tea, salt, spices, cashmere wool, silk, metals and many other goods. As with the other parts of the Silk Roads, silk was only one component, sometimes a small one, of the wide variety of trade goods moved (Williams 2014, 6-11).

These different corridors saw very different scales of traffic, and had different chronologies of use. However, all were important in developing local cultures and polities, and were instrumental in the movement of ideas, goods and peoples. Each was vital in the development of specific polities and/or empires.

${ }^{28}$ All Corridors numbers refer to the numbers allocated in the Silk Roads Thematic Study. 


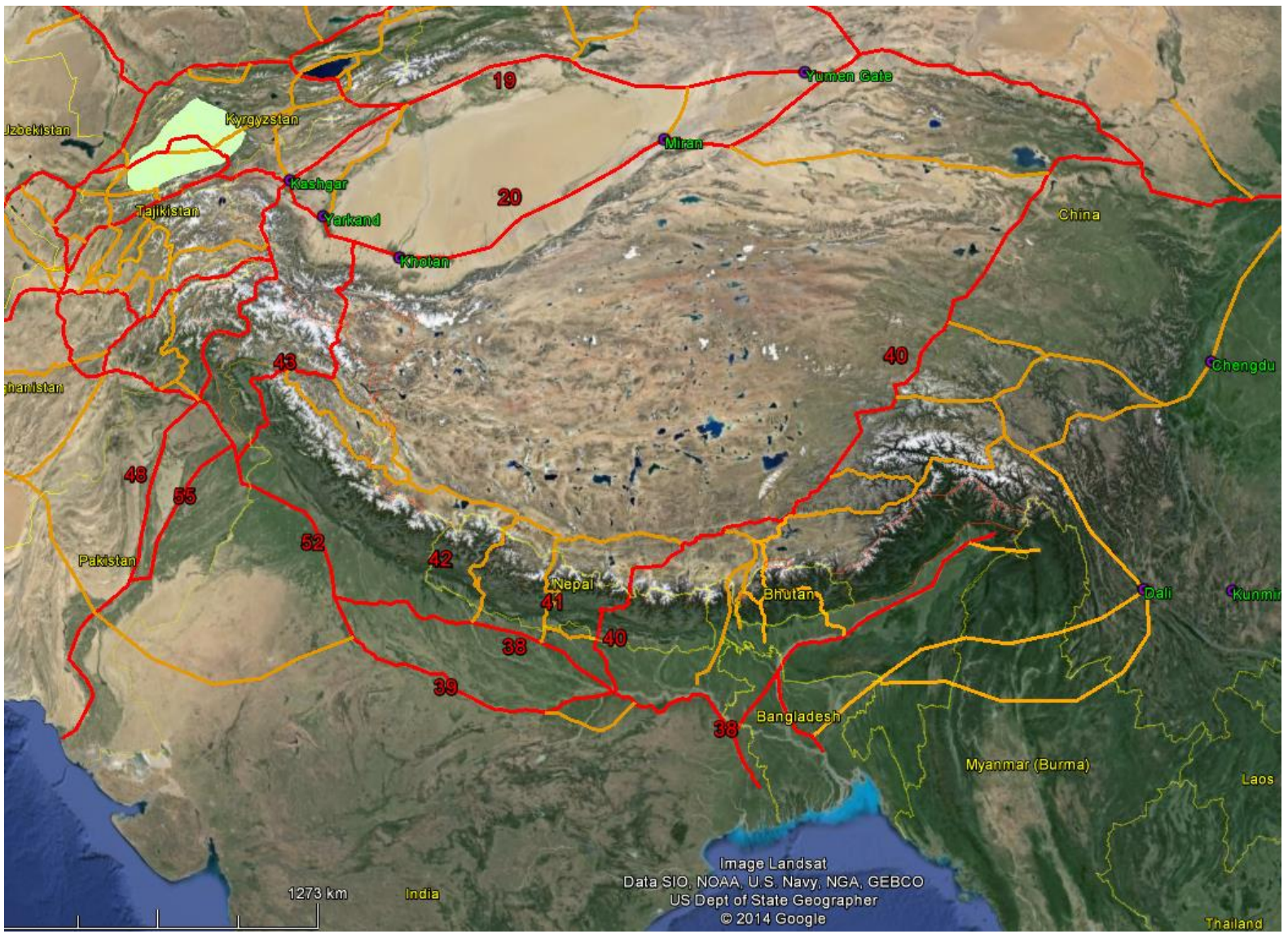

Figure 2. The South Asian region and the principle route identified in the original Silk Roads Thematic Study.

\subsection{Selection of corridors}

There are a number of distinct routes/corridors crossing the region. In discussion at the Kathmandu meeting all of these are considered to be significant, reflecting different empire systems, chronologies and patterns of movements and impacts. The selection of corridors will need to reflect the complexity of the responses to:

i) The environmental and geographic nature of the area: with high plateaus, mountain passes, high mountain valleys, wide fertile river deltas, etc.

ii) The empire system, polities and religions which developed through the interaction with, and control of, the Silk Roads.

\subsection{Tentative lists}

All the countries involved in the South Asian Silk Roads project will need to consider updating their tentative list submissions to reflect the corridors selected. India is the only country with a current Silk Roads tentative list ${ }^{29}$; China did have a Silk Roads tentative list ${ }^{30}$, but this did not encompass any of the sites/landscapes of the Southern Taklamakan, Sichuan/Yunnan, or

29 Silk Road Sites in India (submitted 20/o1/2010): http://whc.unesco.org/en/tentativelists/5492/ ${ }^{30}$ The Silk Roads tentative list covered the now successful serial trans-boundary nomination of the Silk Roads: the Routes Network of Chang'an-Tianshan Corridor (with Kazakhstan and Kyrgyzstan): http://whc.unesco.org/en/list/1442 
the Tibetan plateau.

There will need to be a process of harmonizing the tentative lists (see section 7.2.6 in Williams 2014) to ensure that the different State Parties have collectively included sufficient elements that underpin the Outstanding Universal Value of the nomination (see section 2.5 below).

\subsection{National inventories and continuing research}

The timetable for the preparation of nominations will need to reflect the scale of preparation and knowledge available to each State Party. National inventories, for example, exist at very different levels across the State Parties.

1) China has detailed inventories, but the extent to which these reflect the complexities of the Silk Roads corridors in the region will need to be explored. China has already identified that more field research and capacity building along the Tibetan Plateau may be necessary.

2) India has detailed inventories, but the selection of sites, particularly smaller sites/way-stations, etc., may require further development.

3) Work on some of the routes through Nepal, especially in the western area, might need further work to identify specific sites and landscapes.

4) Bhutan is only just embarking upon a National Inventory and archaeological work on pre- $17^{\text {th }}$ century heritage is still at an early stage of development. As a result, they are some way from being in a position to put forward specific sites and landscapes for a Silk Roads nomination. However, the key routes/corridors are already evident.

\subsection{Site selection within corridors}

The selection of specific sites and landscapes within the corridors is always challenging. It is vital that these reflect the attributes and criteria that have been chosen for the nomination project, and that they reflect the wider criteria developed for the Silk Roads project (see section 7.2.4 in Williams 2014). In this context, it will be vital to capture the complexity of the sociocultural responses to the Silk Roads through:

- The infrastructure of the corridors: way-stations, pillar stones, forts, mountain passes, bridges, small market towns, ports, etc.

- The outcomes: religious monuments and landscapes, large cities, manufacturing centres, etc.

\subsection{Linking with existing World Heritage Sites}

As with the existing Silk Roads project, a number of existing World Heritage Sites will fall within the remit of the Silk Roads initiative. These sites, such as those in the Kathmandu Valley, can appear as part of their corridor nomination, without compromising their existing World Heritage status.

\subsection{Protection and Management}

Overall, the Silk Roads project established an Intergovernmental Coordinating Committee in 2009. This steering committee is comprised of representatives of all States Parties involved in the nominations of Silk Roads corridors. The ICOMOS International Conservation Centre-Xi'an (IICC-X) ${ }^{31}$ acts as the Secretariat for the Committee. The Committee oversees the development of trans-national serial nominations, and aims to provide guidelines on conservation principles, methods, and management.

The successful nomination of the Silk Roads: the Routes Network of Chang'an-Tianshan Corridor provides a potential model for trans-national working and management 
infrastructure for the South Asian Silk Roads project32. A formal agreement for the coordinated management of the sites in the corridor was signed by the three States Parties. This set out management mechanisms, and identified the principles and rules of conservation management. These do not substitute for the management of the specific sites and landscapes selected by the responsible State Party, but rather provide a broader overview of management strategies and principles, shared by the partners. This also provides a framework for periodic reporting. The agreement also established suggestions for exchange and collaboration on conservation, interpretation, presentation and publicity. The Steering Committee for the corridor consists of Vice Ministers. There is also a Working Group, consisting of two experts and one government official from each State Party. Regular meetings are held between the three States Parties. Collaboration is being supported by the development of an on-line information platform at the IICC-X.

A similar model might be envisaged for the South Asian partners for any corridor nominations.

\section{Nomination strategy}

General discussion at the Kathmandu meeting suggested developing a trans-national nomination project based on the best understood corridors, which could go ahead relatively quickly, with other corridors being taken forward as research and resources permit.

The suggested approach includes the following projects.

\subsection{Routes from the Tibetan Plateau to the Gangetic Plain via Nepal}

Develop a Tibetan plateau, Nepal and lower Gangetic Plain project, to include China, Nepal and India: selecting the best understood/prepared central Himalayan corridors for an initial nomination project (Figure 3). Within China it is likely that additional research in the southern Tibetan region may be needed for this project. Within Nepal, the State Party expressed a strong preference for the corridor that stretches North-South between Lo Mantang/Mustang and Lumbini (Corridor 41)33. The eastern route, through the Kathmandu Valley (Corridor 40) would also be important for establishing the major links between Tibet and India. All of these routes extend southward within India and would encompass the lower Gangetic Plain (Corridors 38 \& 39) and the port sites to the south-east (Figure 4).

It is possible that the western China-Nepal-India route (Corridor 42) might be added as an extension to this nomination, when the research platform in Tibet and Nepal was strong enough to do so.

$3^{2}$ See the summary of Protection and Management requirements at http://whc.unesco.org/en/list/1442 33 However, the link between Lo-Mantang/Mustang and China requires investigation. 


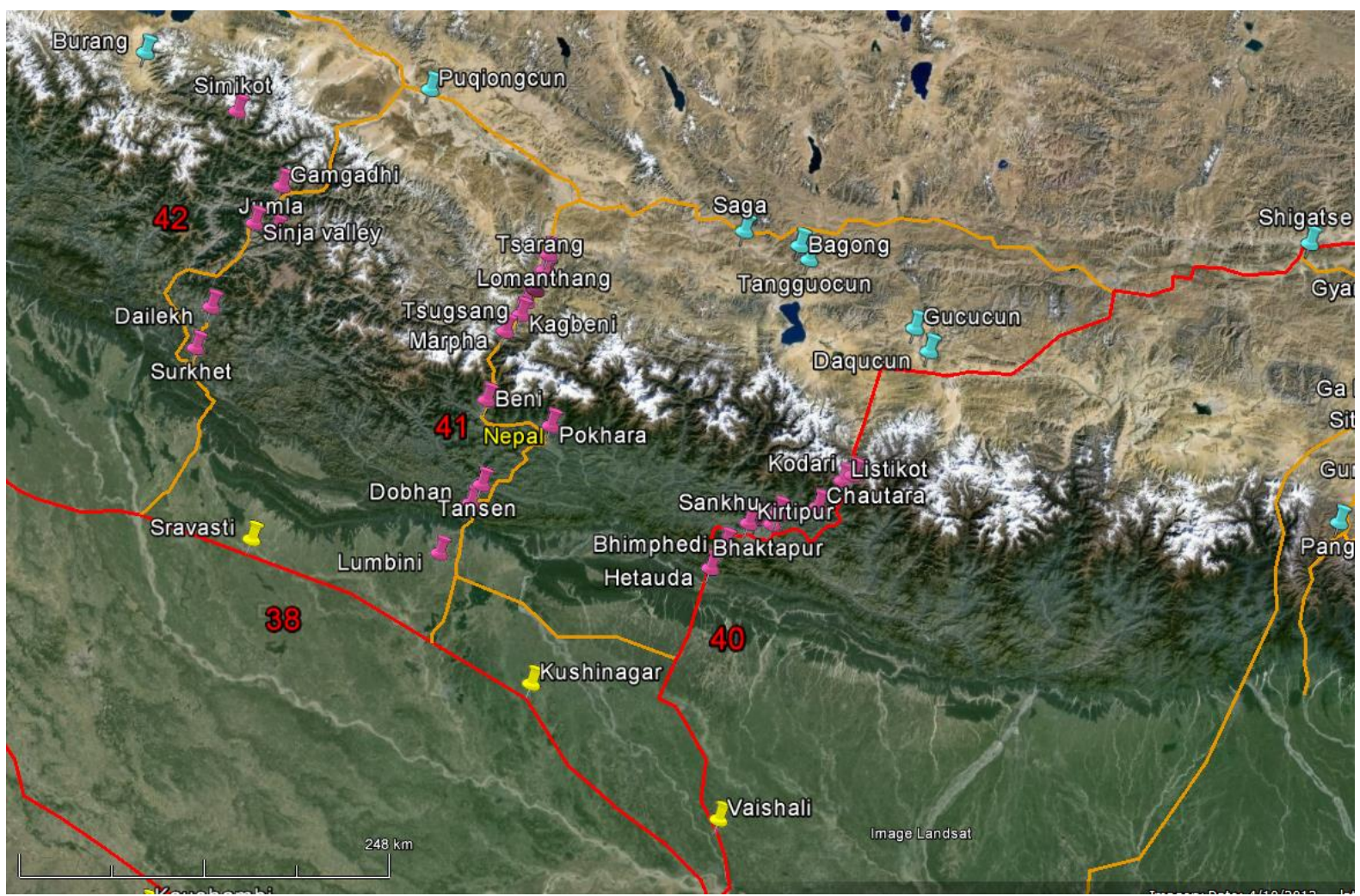

Figure 3. Sites along the Tibetan Plateau and the three corridors through Nepal: the easternmost Kathmandu Valley (Corridor 40), the central (mid-western Nepal) route through Lo Manthang and Lumbini (Corridor 41) and the westernmost route including Jumla and Surkhet (Corridor 42).

Base map: (C) Google. Image Landsat. Data SIO, NOAA, U.S. Navy, NGA, GEBCO. US Dept of State Geographer

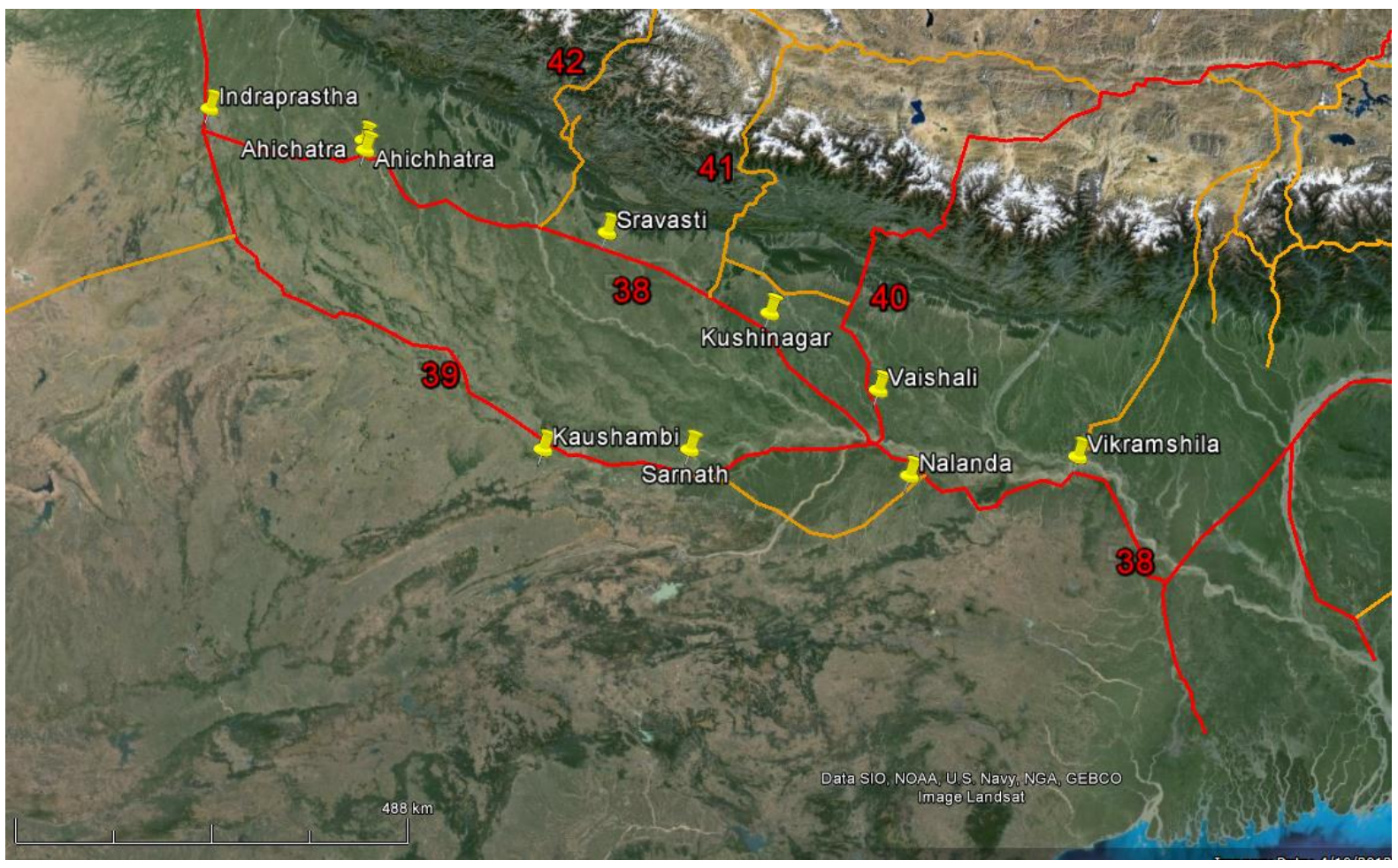

Figure 4. The lower Gangetic Plain. 


\subsection{Southern Taklamakan to north-west India (and beyond)}

Develop a separate nomination project to encompass the China-India corridors (Figure 5) from the Southern Taklamakan (e.g. Yarkand/Khotan - Corridor 20) through western Tibet and Northwest India (e.g. via Leh and Srinagar, to Gujranwala - Corridor 43). This might also include Pakistan, to encompass the other major Karakoram route (via the Khunjerab and Wakhir Passes) from Tashkurgan to Taxila (Corridor 14), and to extend the corridor down the Indus Valley to the ocean (Corridors 48 \& 55).

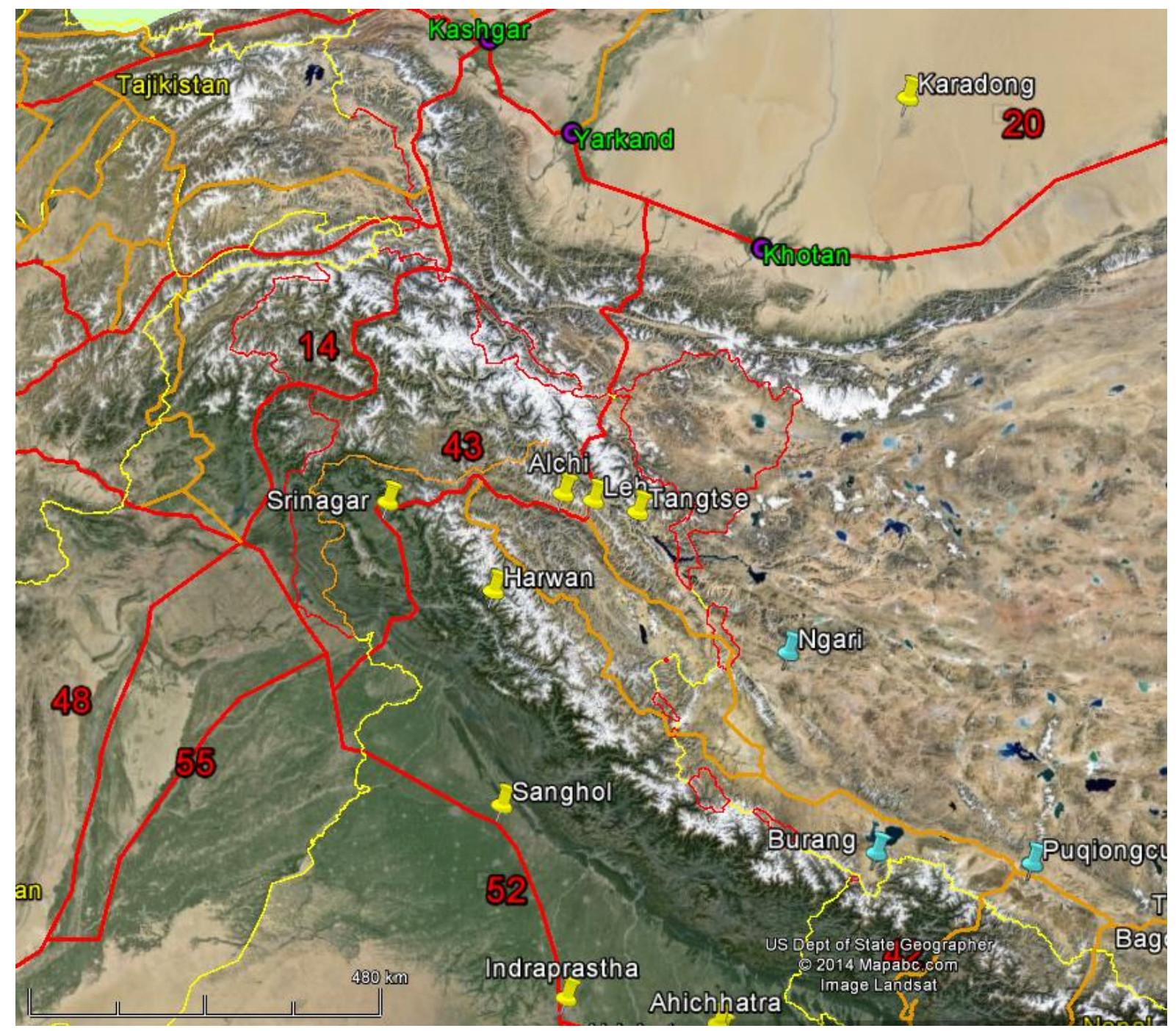

Figure 5. Southern Taklamakan to north-west India (and beyond).

\subsection{Southwest Silk Roads: tea and horse}

The so-called Southwest Silk Roads, or the Tea and Horse routes (Figure 6), encompassing Yunnan, Sichuan, Tibet, Bhutan, Myanmar and north-east India (Darjeeling) to the coast 34 , formed a vitally important network of trade connections that had a major impact upon the

34 It would be interesting to involve Bangladesh in this project, to encompass the routes down to the ports in the Bay of Bengal. 
development of the region (see section 4.1.3 below). There is a consideration as to whether these routes comprise part of the Silk Roads South Asian project, or might be conceived as a separate project.

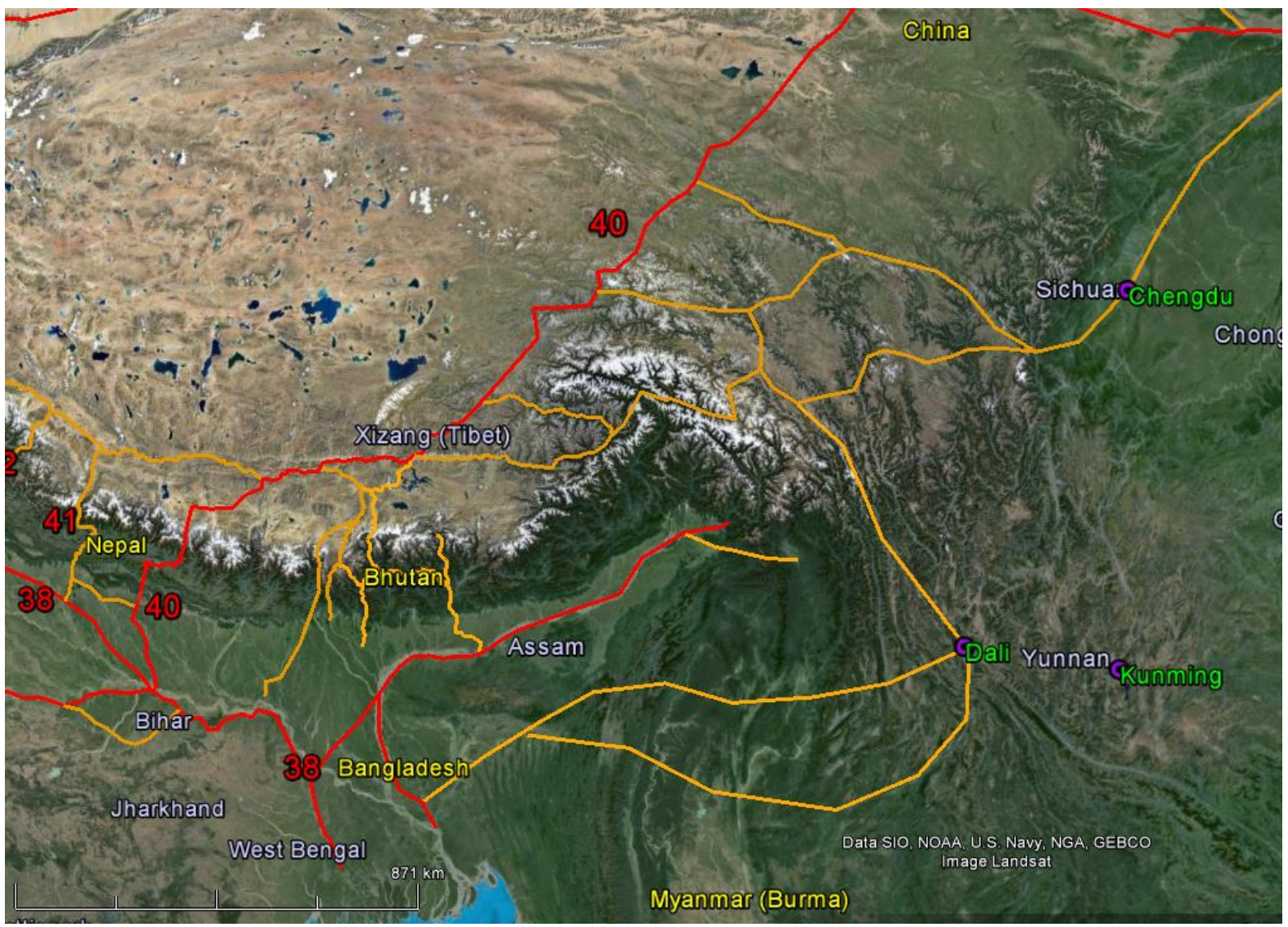

Figure 6. Beginning to examine the routes between Yunnan and Sichuan (right), through Bhutan and Myanmar, to India and Bangladesh.

\subsection{The northwest frontier routes to Central Asia}

Consider developing a western project to include Afghanistan, Pakistan and India35 to enable the north-western routes from South Asia to Central Asia to be nominated (Corridors 12 and 52) (Figure 7). 


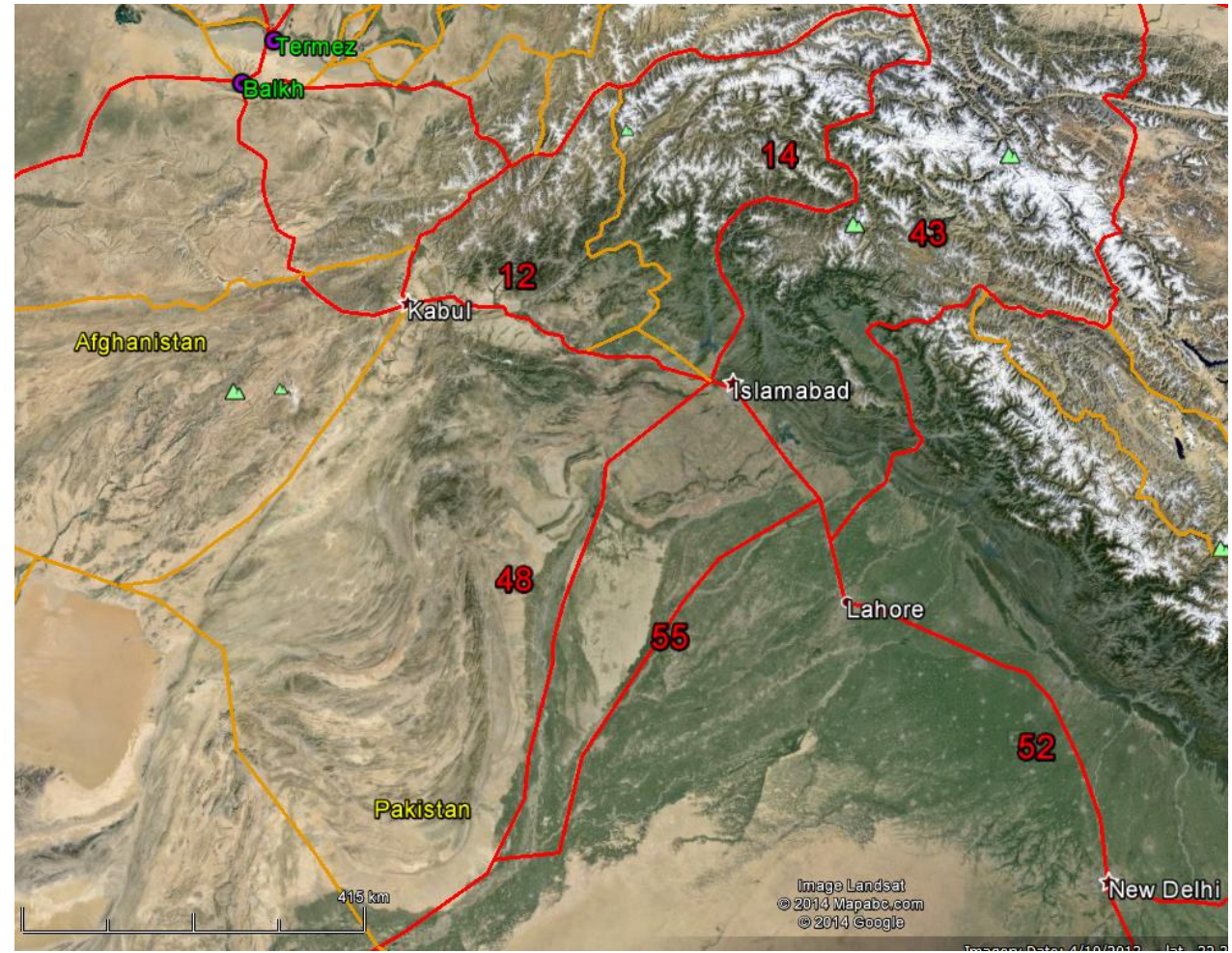

Figure 7. The northwest frontier routes to Central Asia.

\section{Comments on specific corridors}

\subsection{China}

\subsubsection{Southern Taklamakan routes}

It would be useful to consider the extent to which this initiative would be an opportunity to encompass the southern Taklamakan routes (Corridor 20 in the ICOMOS Thematic Study). This is an internationally significant route, with a number of very important sites within the corridor (e.g. Miran, Waxxari, Chrachan, Endere, Niya and Khotan), which reflect very different adaptations, chronologies and empires to the northern routes (Corridor 19: some of which were included in the first nomination project).

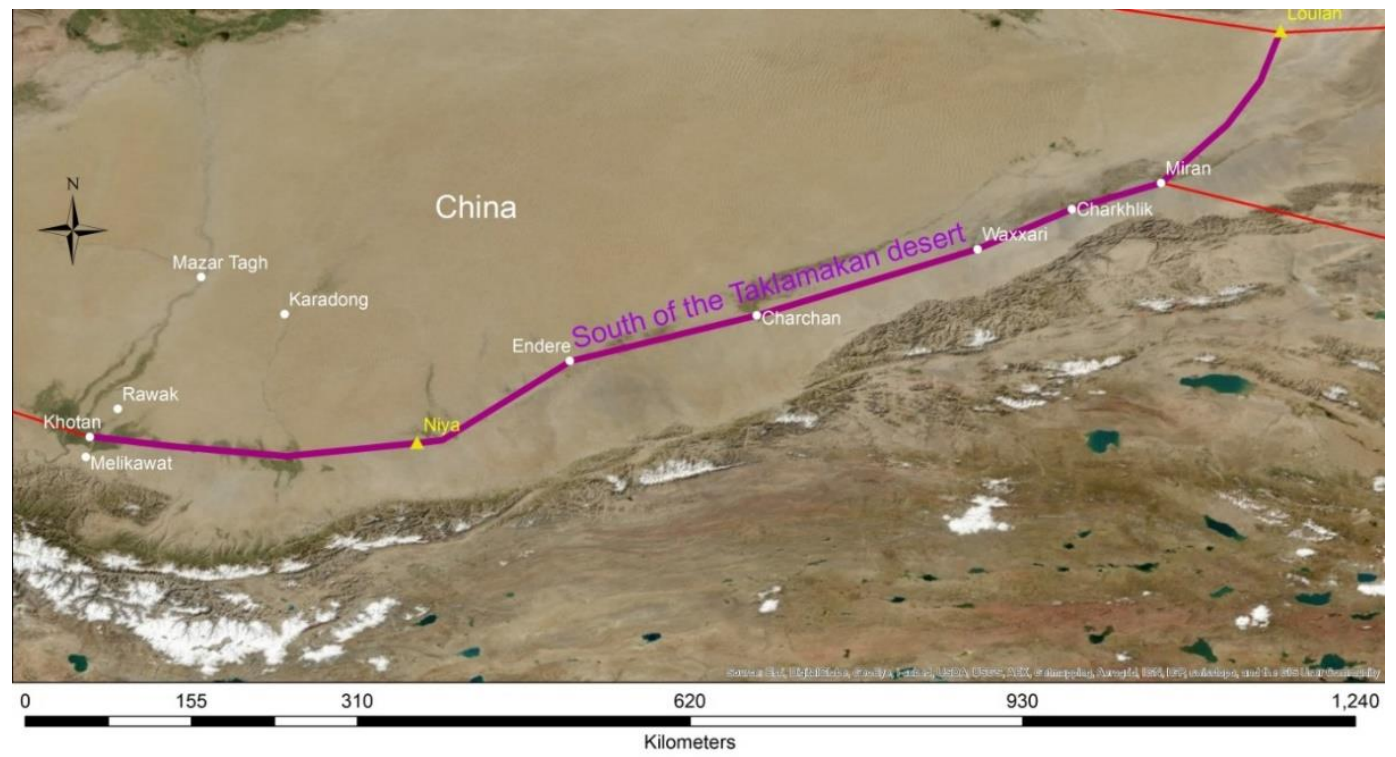

Figure 8. The Southern Taklamakan corridor. 


\subsubsection{The Tibetan plateau}

The archaeology of the high Tibetan plateau has been explored (e.g. recently Tong 2013 for the northern area), but there is still much to do to understand the routes and surviving evidence along the plateau.

\subsubsection{Yunnan \& Sichuan: the 'Southwest Silk Roads'}

"Previous studies ... downplay the global significance of the Southwest Silk Road" (Yang 2008, 5). There is clearly a complex interaction between south-west China (especially Yunnan and Sichuan provinces) and South Asia. These are hugely significant, not just the exchange for trade goods but also the movement of ideas and philosophies (e.g. Janice Stargardt's study (1971) on medieval Burma demonstrated the scale of the overland routes and their interrelationship in the later periods with the Maritime Silk Road).

From Yunnan the so-called Tea Horse Road (茶马古道) was extremely important from the Tang dynasty (618-907 CE) onwards, although its peak was probably during the late-Qing period (1790s to $1911 \mathrm{CE})^{36}$. The routes between Sichuan and Tibet may be even earlier, and by the Song Dynasty (960-1279 CE) the tea trade from Sichuan (Ya'an) was controlled by the official 'Tea and Horse Bureau'. There are substantial documentary records of the scale of trade, in both Chinese and Tibetan, and the importance of these routes should not be underestimated.

There are numerous surviving archaeological and monumental elements - including trails, bridges, way stations, market towns, palaces, staging posts, shrines and temples - which make it a strong nomination project. The route was not simply important for commercial activity: more significantly it was crucial for cultural exchange between the Indian subcontinent, Tibet and Southwest China, and perhaps most significantly it was vitally important for the interchange of Buddhism between China and South Asia.

These corridors would make excellent trans-national heritage route projects. Whether they should be part of the Silk Roads South Asia initiative - or a separate nomination project - is something that the State Parties may wish to debate.

\subsection{India}

\subsubsection{Port cities}

The Silk Roads corridors could be extended as far as the port cities in north-western and northeastern India, which would provide a strong linkage to maritime Silk Routes ${ }^{37}$. The relationship between port cities and their hinterlands was an important driver in trade contacts and is likely to have been a significant factor in stimulating the movement of materials (and peoples) from the Tibetan plateau down into the Indian subcontinent and vice versa.

\subsubsection{Ladakh and the western routes}

The routes through western Tibet, connecting the significant routes along the Southern Taklamakan Desert to the Indian subcontinent, were hugely important in the development of the region and the spread of religious ideas. For example, around the 1st century CE Ladakh became part of the Kushan Empire and Buddhism spread into western Ladakh from Kashmir in the 2nd century CE. By the 8th century CE, Ladakh was involved in the clash between Tibetan expansion and Chinese influence exerted from Central Asia through the high mountain passes. The routes through this region were fundamental in the spread of religious ideas, for example, Nestorian crosses carved into boulders found in Tangtse have been attributed to Sogdian Christian merchants, and Arabic inscriptions are evidence of the

${ }^{6} 6$ China has already identified the Ancient Tea Plantations of Jingmai Mountain in Pu'er (see Tentative List: http://whc.unesco.org/en/tentativelists/5810/) as a possible World Heritage Site. 37 A separate nomination project which may be developed at a later stage. 
importance of trade in this region.

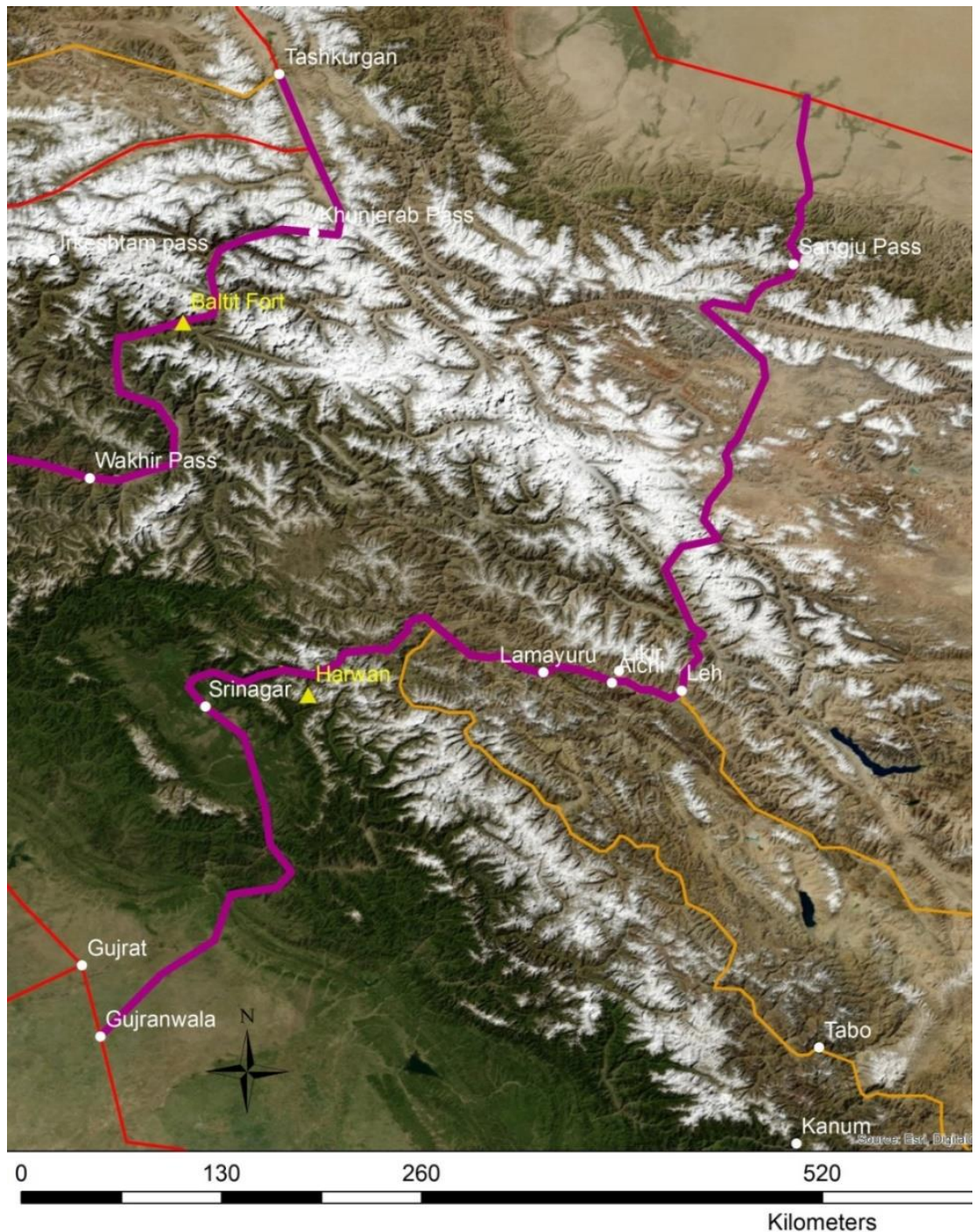

Figure 9. Through the high Karakoram - from the southern Taklamakan through Srinagar, Leh and Sangju Pass to the Gangetic Plain. Base map: @ ESRI, DigitalGlobe

The corridors connecting the Taklamakan, Tibet and Ladakh could also be logically extended down the Indus Valley to encompass the corridors that connected this region to the coast (Corridor 55). This would, of course, involve developing Pakistan as part of this nomination.

If Pakistan were involved, then the potential of including the other major Karakoram route (via the Khunjerab and Wakhir Passes) from Tashkurgan to Taxila (Corridor 14) would make this an even stronger nomination project.

\subsubsection{Darjeeling}

Important routes link the Darjeeling region with the trans-Himalayan routes and down into the Indian lowlands. These routes are closely linked with those of western Bhutan and it would be an exciting project to link these corridors.

\subsubsection{Routes along the Ganges}

These complex corridors encompass a number of major cities and monuments. The corridor of movement here is broad, with numerous axis of movement along the Gangetic Plain (Figure 10). These routes are vitally important, linking the trans-Himalayan trade and movement networks with highly productive agricultural areas and the interplay between terrestrial and maritime trade. 
The nature of the plain suggests that extending the corridor into Bangladesh would enable the nomination to link the east-west and north-south corridors most effectively (Figure 11).

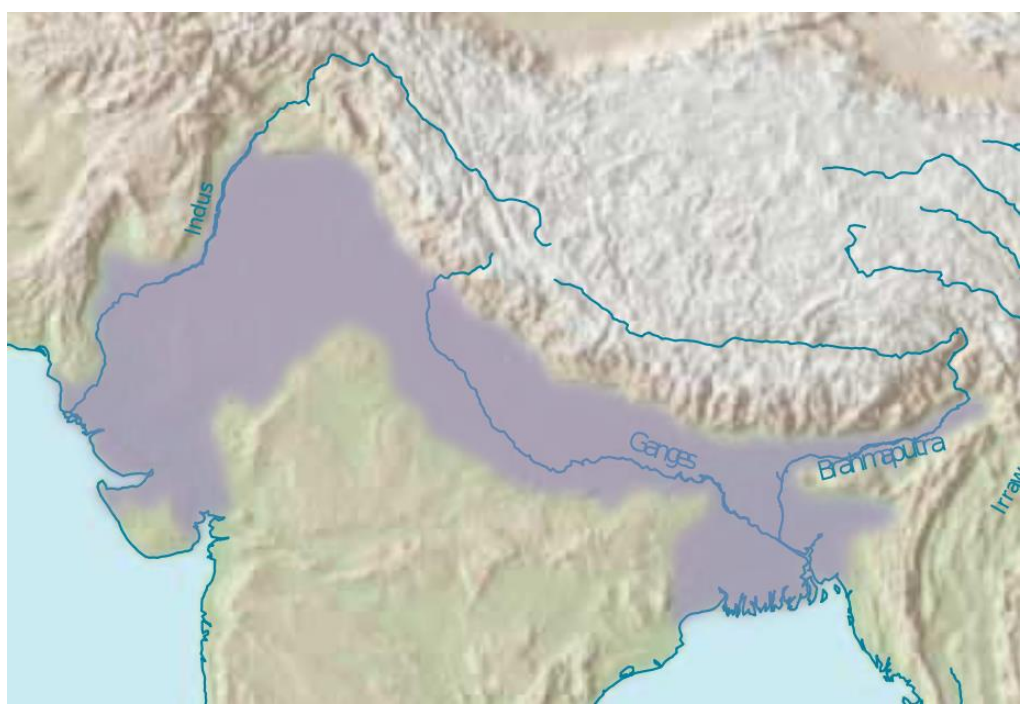

Figure 10. The Indo-Gangetic Plain: the fertile plain of the Ganges and Indus river systems. Base map: (c) ESRI, DigitalGlobe

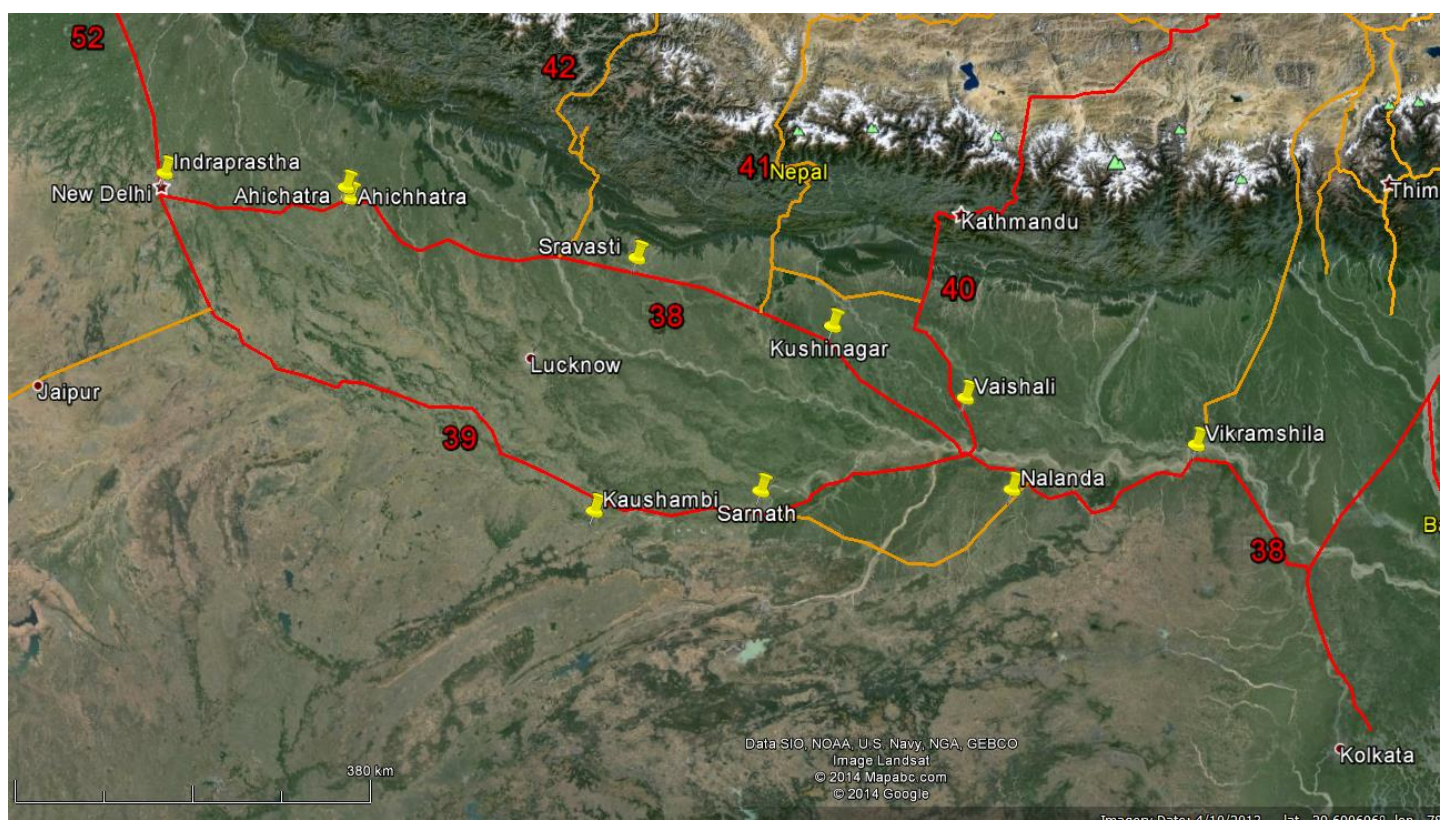

Figure 11. The corridors through the Gangetic Plain: the wide fertile river system of the Ganges enabled sites to develop over a broad area and there were multiple routes across this landscape. At present two corridors (Corridors 38 and 39) have been defined, encompassing the main urban developments and monuments, but a single wider corridor probably may be more appropriate, linking into the network of north-south routes across the Himalayas.

\subsubsection{North-south connections: around the Thar Desert to the ocean}

As with the potential linking to the routes southward to the coast through the Indus Valley (see 4.6), the routes around the Thar Desert, and through Rajasthan, down to the Gulf of Kutch, Gujarat, Sopara, etc. would also be important to integrate the north-south and east-west connections. 


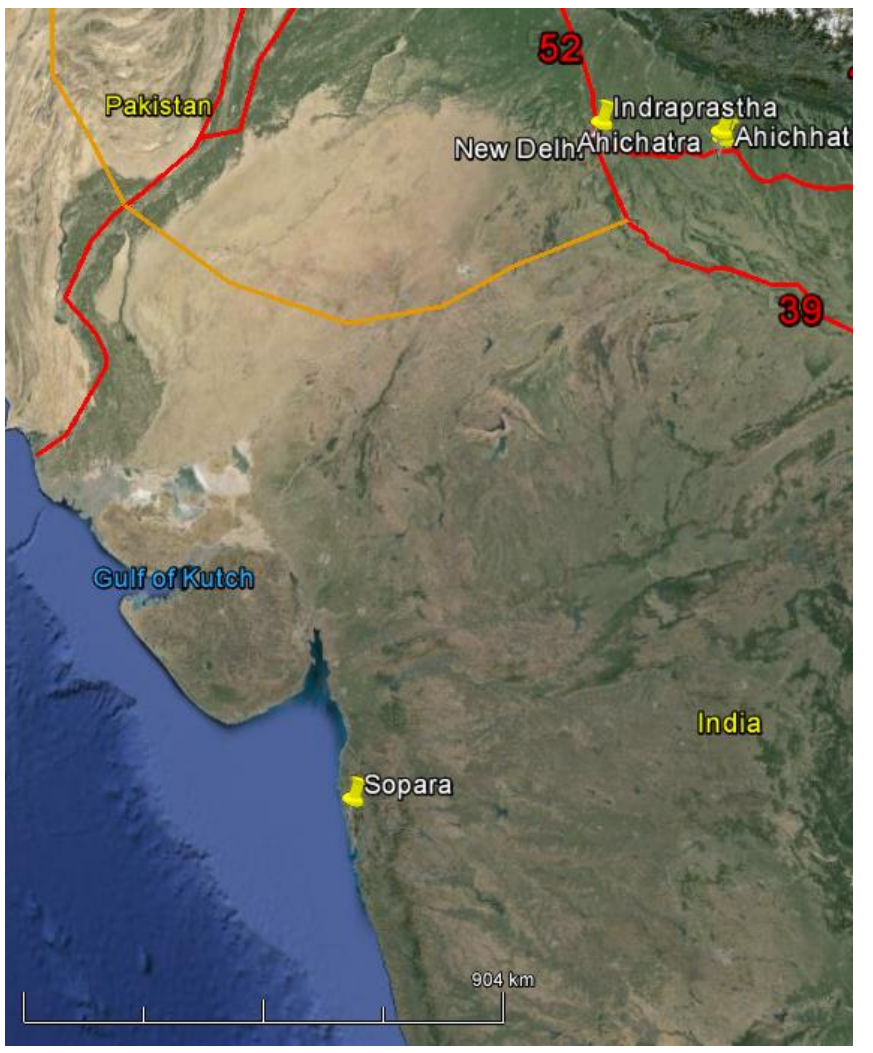

Figure 12. The routes (not yet mapped) south-westward to the Ocean.

Base map: (c) Google.

\subsection{Nepal}

The extent to which any Silk Roads nomination might integrate existing tentative list sites/landscapes, such as the Medieval Earthern Walled City of Lo Manthang ${ }^{38}$, needs to be considered.

There is still work to be done to agree the nature of the western routes in Nepal, and to provide the documentation of the sites/archaeology along these corridors.

\subsection{Bhutan}

The possible routes and sites/monuments/landscapes in Bhutan were discussed at a recent workshop in Bhutan (20-22 August 2014) ${ }^{39}$. The National Inventory system will be important in providing a platform to discuss site selection, but it was also recognised that Bhutan currently has limited documentation on pre-17th century sites and that it is likely that the identification of specific sites and landscapes would take some time. Indeed, there are numerous challenges to developing a Silk Roads strategy for Bhutan. The most fundamental is the lack of current research on pre- $17^{\text {th }}$ century archaeology, with the lack of data making the identification of routes and specific sites/monuments or landscapes for inclusion difficult at this stage.

The potential is clearly high: modern-day Bhutan occupied a crucial strategic position on the routes both from Tibetan Sichuan and Yunnan (e.g. Tea Horse routes, see Freeman \& Ahmed 2011; Fuchs 2008) and from Tibet down the 'southern valley' systems (e.g. Salt routes) to India and Bangladesh. The foundation of early monastic settlements (e.g. the documentary sources suggesting the foundation of the mediation centre at Taktsang Palphug Monastery in the $8^{\text {th }}$ century CE; or the foundation of Choedrak Monastery in the $12^{\text {th }}$ century, or Phajoding monastery in the $13^{\text {th }}$ century) reinforce that there was a developed settlement pattern in the fertile valleys of Bhutan that significantly pre-dates the current monuments. The Dzongs constructed as part of the unification of Bhutan after 1616 by Zhabdrung Ngawang Namgyel were evidently securing existing polities in the important valley systems of western and central Bhutan.

There are some fundamental research issues confronting the development of the component of the National Inventory pre-dating the $17^{\text {th }}$ century, not least the limited amount of archaeological work and the concomitant problems of understanding early material culture. There is a lack of research into ceramics, dating evidence, etc., compounded by the apparent continuity of material traditions in cooking vessels - and the use of metalwork and wood for high prestige goods and the use of leather sacks for storage ${ }^{40}$, all of which have significant

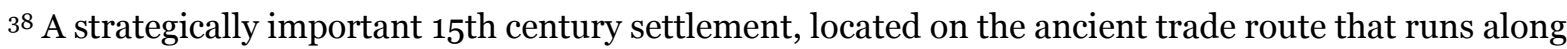
the Kali Gandaki River and the Himalayas, see http://whc.unesco.org/en/tentativelists/5256/

39 Supported by the UNESCO/Korean Funds-in-Trust South Asian Silk Roads project.

40 The Folk Heritage Museum, Thimphu. 
problems of survival in the archaeological record. However, significant quantities of ceramics were recovered during the recent Swiss-Bhutanese project (Yeshi Samdrup pers. comm. 2014), which suggests that it may well be possible to develop a regional ceramic sequence. In addition, the recently published research on Ogyen Choling (Choden \& Roder 2012) demonstrates the complexity of landscapes and routes, and the ability of local studies to begin to understand the development of earlier settlement landscapes.

\subsection{Bangladesh}

It is worth considering the inclusion of Bangladesh and Pakistan in the South Asian Silk Roads project.

The routes down through Bhutan, and also between south-western China and the Indian subcontinent, logically connect these systems with the northern trading ports in the Bay of Bengal. In addition, the routes through the Gangetic Plain (section 4.2.4) could also be seen to encompass Bangladesh.

\subsection{Pakistan}

The north-south routes in the west of the South Asia region would logically draw in the corridors down the Indus Valley to the coast, linking with Pakistan.

As with the Gangetic Plain routes (4.2.4), linking the north-south routes into the corridors extending down the Indus Valley would enable the full impact of these aspects of the Silk Roads to be encompassed in any nomination strategy.

\section{Perhaps most easily the Indus Valley corridor (which would of course involve Pakistan) (}

Figure 13) could most successfully be integrated with the Ladakh and western Tibet routes to the Taklamakan, while the north-south routes from the central Himalayan region (through Nepal) might link into the routes running south-westward from the Gangetic Plain to the coast.

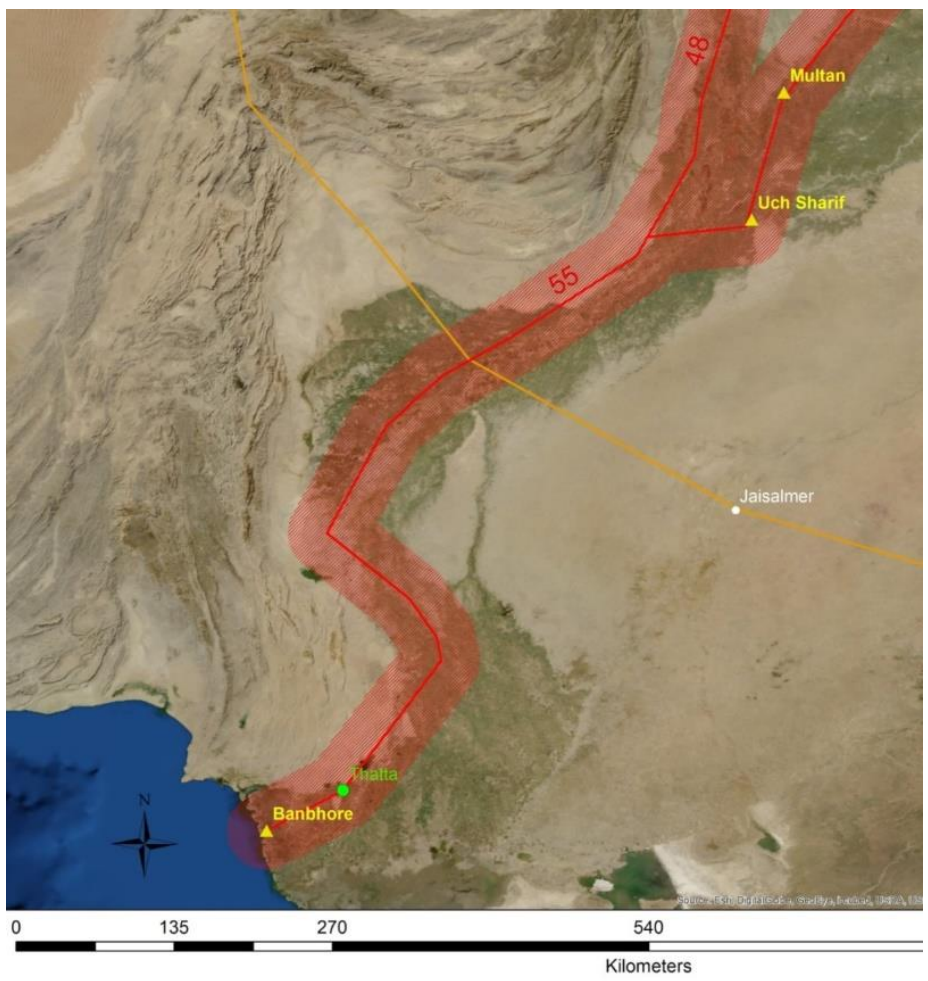

Figure 13. The Indus Valley Base map: C) ESRI 


\section{References}

Choden, K \& Roder, D C (eds) (2012) Ogyen Choling: a manor in central Bhutan. Thimphu: Riyang Books

Fisher, J F (1992) Trans-Himalayan Traders: Economy, Society and Culture in North-west Nepal. Los Angeles: University of California Press

Freeman, M \& Ahmed, S (2011) Tea horse road: China's ancient trade road to Tibet. Bangkok: River Books

Fuchs, J (2008) The Ancient Tea Horse Road: Travels With the Last of the Himalayan Muleteers. Renouf Pub Co Ltd

Rizvi, J (2000) Trans-Himalayan Caravans: Merchant Princes and Peasant Traders in Ladakh. OUP India

Stargardt, J (1971) Burma's Economic and Diplomatic Relations with India and China from Medieval Sources, Journal of Economic and Social History of the Orient 14: 38-62

Tong, T (2013) The Silk Roads of the Northern Tibetan Plateau During the Early Middle Ages (from the Han to Tang Dynasty). Oxford: Archaeopress

Williams, T (2014) Silk Roads: an ICOMOS thematic study. Charenton-le-Pont: ICOMOS

Yang, B (2008) Between winds and clouds: the making of Yunnan (Second Century $B C E-T w e n t i e t h$ Century $C E$ ). New York: Columbia University press 


\section{Appendix 2: Recommendations for the South Asian Silk Roads (2014)}

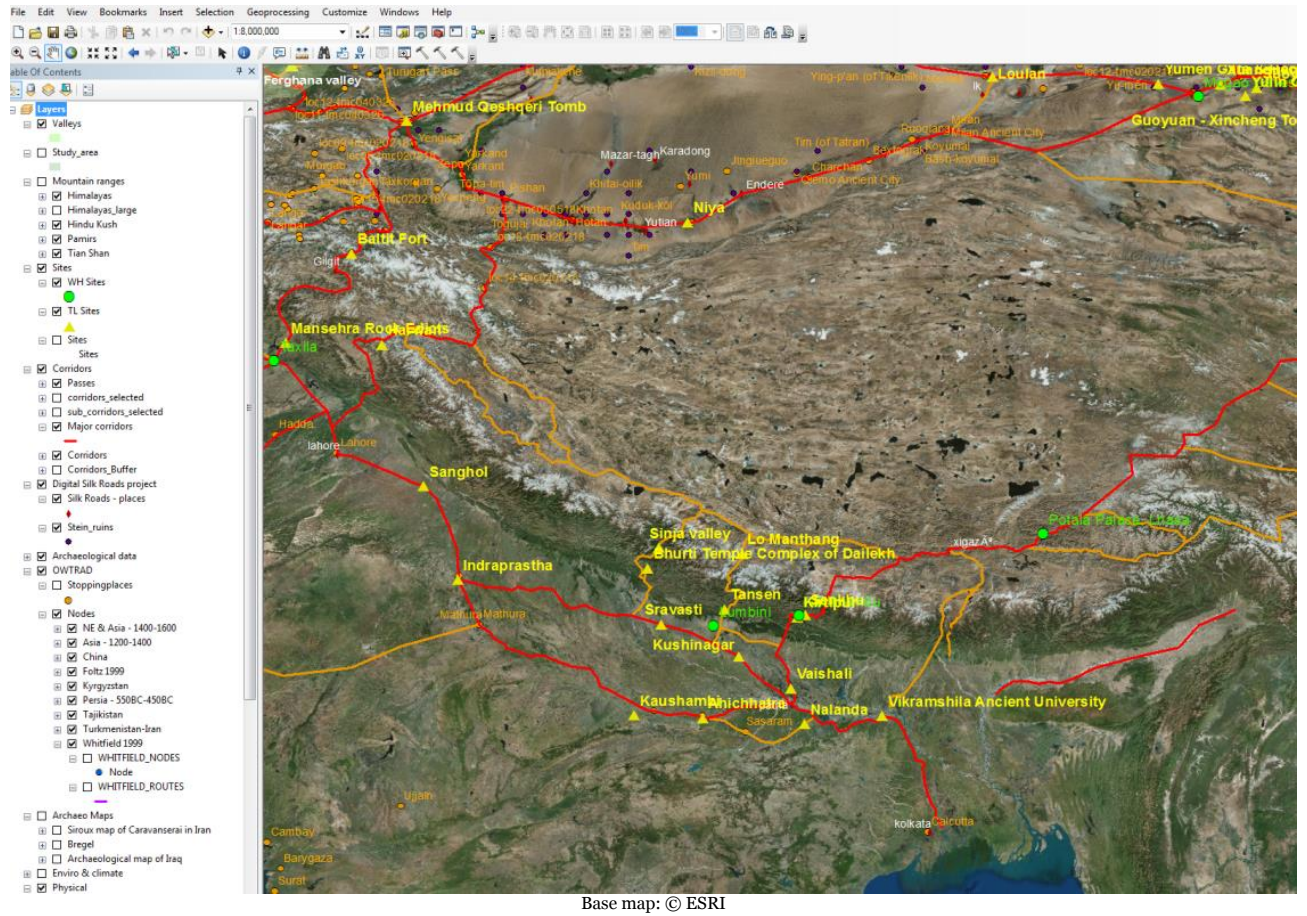

Example of developing GIS \& data exchange systems for the South Asian region

\section{Tim Williams}

\section{Institute of Archaeology, UCL}

Prepared within the framework of the UNESCO/Korean Funds-in-Trust project "Support for the preparation for the World Heritage Serial Nomination of the Silk Roads in South Asia", and with the support of the UNESCO World Heritage Centre and UNESCO Offices in

Kathmandu and in New Delhi

December 2014 


\section{Introduction}

These recommendations are based on missions to Bhutan, Nepal and Indian in 2013-14. These culminated in a draft South Asian Silk Roads: Serial and Transnational World Heritage Nomination Strategy (hereafter referred to as the Nomination Strategy), prepared in advance of a meeting in Kathmandu, Nepal 23-24 September 2014 (see section 4.6.5). This was subsequently revised, after the discussions at that meeting, and circulated to State Parties. It was finalised in December 2014.

These recommendations also take account of the Kathmandu Action Plan of the first South Asian priority transnational heritage corridor(s) (hereafter the Action Plan) agreed at the Sub-regional Workshop on the Nomination Strategy for the South Asian Silk Roads, Kathmandu, Nepal, 23-24 September 2014 (see section 4.7).

The Action Plan identified:

REC 1.1 Consideration of whether a Concept Paper for the South Asian priority transnational Silk Roads heritage corridor(s) was needed. This needs to be resolved.

\section{National inventories and continuing research}

See sections 2.4, 3 \& 4 in the Nomination Strategy

REC 2.1 China has identified that more field research and capacity building along the Tibetan Plateau is necessary.

REC 2.2 China to explore integrating the Southern Taklamakan sites into this initiative.

REC 2.2 India has detailed inventories, but the selection of sites, particularly smaller sites/way-stations, etc., and in the north-east and north-west of the country (see 4.2 in the Nomination Strategy), requires further development.

REC 2.3 Nepal needs to undertake further work to identify specific sites and landscapes, especially in the central and western corridors.

REC 2.4 Bhutan is embarking upon a National Inventory41, which needs to be implemented.

REC 2.5 Bhutan needs assistance to develop capacities in pre-17th century heritage.

\section{Tentative lists}

See section 2.3 in the Nomination Strategy

REC 3.1 All the countries involved in the South Asian Silk Roads will need to update their tentative list submissions to reflect the corridors finally selected.

REC 3.2 All parties will need to harmonize their tentative lists to ensure that collectively they include sufficient elements that underpin the Outstanding Universal Value of the nomination.

${ }^{41}$ Details of this are covered in the Bhutan National Heritage Inventory: Draft forward plan, a report compiled by a UCL team in consultation with the Bhutan DCHS, August 2014. 


\section{Steering committee}

See section 2.7 in the Nomination Strategy

REC 4.1 Establish Steering Committee and Working Group for the South Asian Silk Roads initiative.

\section{Southwest Silk Roads: Tea \& Horse routes}

See sections $3.3 \& 4.1 .3$ in the Nomination Strategy

REC 5.1 China to consider approaches to the nomination of the Tea \& Horse routes in south-western China, and their inclusion in the South Asian Silk Roads project as the 'Southwest Silk Roads'.

REC 5.2 Consider the ramifications of REC 5.1 on the State Parties involved in the Nomination Strategy (see below) and its' Committees/Working Groups.

\section{State Parties}

See sections 3 \& 4 in the Nomination Strategy

REC 6.1 Consider inviting Myanmar and Bangladesh to join the State Parties involved in the South Asian initiative, if Southwest Silk Roads (see REC 5.1) are integrated into programme.

REC 6.2 Consider inviting Pakistan to join the South Asian initiative (see 3.4 \& 4.6 in the Nomination Strategy).

\section{GIS and management information systems}

See Action Plan

REC 7.1 A coordinated system for data management and exchange needs to be developed amongst the partners.

REC 7.2 The possibility of utilising the future category II centre in New Delhi should be explored.

REC 7.3 Discussions should take place with the International Centre for Integrated Mountain Development (ICIMOD) ${ }^{42}$, to explore common approaches and the potential to engage the organisation in both data management/exchange and capacity building (especially in the field off Geographic Information Systems)

42 Perhaps building on their experience with the Kailash Sacred Landscape Conservation and Development Initiative and Ecosystem Management Analyst. 


\section{Appendix 3: Draft Action Plan in consideration of the submission deadline of 1 February 2018 of the first South Asian priority transnational heritage corridor(s)}

Adopted at the sub-regional workshop, 23-24 September 2014, Kathmandu, Nepal.

Organized by UNESCO and the Department of Archaeology, Ministry of Culture, Tourism and Civil Aviation, Nepal.

Supported by UNESCO/Korean Funds-In-Trust Project

\begin{tabular}{|c|c|c|c|}
\hline State-parties & Expected results of the work & Timeframe & $\begin{array}{l}\text { Potential } \\
\text { Funding }\end{array}$ \\
\hline $\begin{array}{l}\text { Bhutan, China, India } \\
\text { and Nepal }\end{array}$ & $\begin{array}{l}\text { Final Feedback on the Draft Serial and } \\
\text { Transnational World Heritage } \\
\text { Nomination Strategy for the South } \\
\text { Asian Silk Roads and the Draft Action } \\
\text { Plan }\end{array}$ & $\begin{array}{l}\text { End October } \\
2014\end{array}$ & \\
\hline \multirow[t]{2}{*}{$\begin{array}{l}\text { China, India and } \\
\text { Nepal } \\
\text { Bhutan }(?)+\ldots\end{array}$} & $\begin{array}{l}\text { Consideration, besides Nomination } \\
\text { Strategy, if Concept Paper for the } \\
\text { identified South Asian priority } \\
\text { transnational Silk Roads heritage } \\
\text { corridor(s) needed? }\end{array}$ & December 2014 & \multirow[t]{2}{*}{$\begin{array}{l}\text { UNESCO } \\
\text { Korean FIT } \\
\text { Project + India, } \\
\text { China (?) }+\ldots\end{array}$} \\
\hline & $\begin{array}{l}\text { Agree upon the first South Asian } \\
\text { priority transnational Silk Roads } \\
\text { heritage corridor(s) }\end{array}$ & May 2015 & \\
\hline $\begin{array}{l}\text { Silk Roads } \\
\text { Coordinating } \\
\text { Committee } \\
\text { Members: currently } \\
12 \text { countries } \\
\text { including China, } \\
\text { India and Nepal } \\
\text { Bhutan (Observer); } \\
\text { Pakistan (?); } \\
\text { Bangladesh (?); } \\
\text { Myanmar (?)+ .... }\end{array}$ & $\begin{array}{l}\text { Fourth meeting of the Silk Roads } \\
\text { Serial Transnational World Heritage } \\
\text { Nomination Intergovernmental } \\
\text { Coordinating Committee } \\
\text { Presentation and report to the } \\
\text { Coordination Committee on the } \\
\text { progress of South Asian Silk Roads } \\
\text { works conducted by the State Parties }\end{array}$ & $\begin{array}{l}\text { May } 2015 \\
\text { (potential } \\
\text { timing) }\end{array}$ & $\begin{array}{l}\text { UNESCO } \\
\text { Korean FIT } \\
\text { Project + } \\
\text { UNESCO Japan } \\
\text { FIT Project + } \\
\text { Hosting \& } \\
\text { participating } \\
\text { country }\end{array}$ \\
\hline $\begin{array}{l}\text { China, India and } \\
\text { Nepal } \\
\text { Bhutan (Observer) + } \\
\text {... }\end{array}$ & $\begin{array}{l}\text { Potential establishment of South Asian } \\
\text { Silk Roads Steering Committee and } \\
\text { Working Group for the first South } \\
\text { Asian priority transnational Silk Roads } \\
\text { heritage corridor(s) }\end{array}$ & July 2015 & $\begin{array}{l}\text { Country's own } \\
\text { cost, UNESCO } \\
(?)\end{array}$ \\
\hline $\begin{array}{l}\text { China, India and } \\
\text { Nepal } \\
\text { Bhutan (Observer) + } \\
\text {.... }\end{array}$ & $\begin{array}{l}1^{\text {st }} \text { meeting of the South Asian Silk } \\
\text { Roads Working Group (identification } \\
\text { of the content of the definition for the } \\
\text { inscription; updating the World } \\
\text { Heritage Tentative List of Silk Roads }\end{array}$ & $\begin{array}{l}\text { August/ } \\
\text { September } 2015\end{array}$ & to be decided \\
\hline
\end{tabular}




\begin{tabular}{|c|c|c|c|}
\hline & $\begin{array}{l}\text { by the State Parties) } \\
\text { Preparation of the Memorandum on } \\
\text { preparation of documentation of the } \\
\text { nomination }\end{array}$ & & \\
\hline $\begin{array}{l}\text { China, India and } \\
\text { Nepal } \\
\text { Bhutan (Observer) + } \\
\text {... }\end{array}$ & $\begin{array}{l}2^{\text {nd }} \text { meeting of the South Asian Silk } \\
\text { Roads Working Group } \\
\text { Memorandum for preparation of serial } \\
\text { and transnational nomination of South } \\
\text { Asian Silk Roads sites for the UNESCO } \\
\text { World Heritage list } \\
\text { Within the Steering Committee/ } \\
\text { Working Group, consideration to } \\
\text { create body for the monitoring, } \\
\text { conservation and management of } \\
\text { nominated Silk Roads sites } \\
\text { Harmonization of the preparation } \\
\text { process of the South Asian Silk Roads } \\
\text { corridor nomination (including } \\
\text { harmonisation of the South Asian Silk } \\
\text { Roads Tentative Lists) } \\
\text { First meeting of the Steering } \\
\text { Committee }\end{array}$ & December 2015 & $\begin{array}{l}\text { Countries + } \\
\text { UNESCO (?) }\end{array}$ \\
\hline $\begin{array}{l}\text { China, India and } \\
\text { Nepal } \\
\text { Bhutan (?) }+\ldots\end{array}$ & $\begin{array}{l}\text { Official Submission of updated Silk } \\
\text { Roads World Heritage Tentative Lists } \\
\text { in the participating State Parties }\end{array}$ & $\begin{array}{l}\text { As early as } \\
\text { possible, at latest } \\
\text { by } 1 \text { February } \\
2017\end{array}$ & to be decided \\
\hline $\begin{array}{l}\text { China, India and } \\
\text { Nepal } \\
\text { Bhutan (Observer) + } \\
\text {... }\end{array}$ & $\begin{array}{l}3^{\text {rd }} \text { meeting of the South Asian Silk } \\
\text { Roads Working Group - } \\
\text { Harmonization of the preparation } \\
\text { process of the South Asian Silk Roads } \\
\text { corridor nomination (approval of the } \\
\text { content of the dossier) } \\
\text { Report on the progress of South Asian } \\
\text { Silk Roads works conducted by the } \\
\text { State Parties and (including OUV, } \\
\text { state, authenticity, integrity, } \\
\text { comparative analyses) identification } \\
\text { and approval of boundaries and buffer } \\
\text { zones, as well as transboundary } \\
\text { management and protection } \\
\text { mechanisms }\end{array}$ & December 2016 & to be decided \\
\hline $\begin{array}{l}\text { China, India and } \\
\text { Nepal } \\
\text { Bhutan }(?)+\ldots\end{array}$ & $\begin{array}{l}\text { Creation of the shared archive and } \\
\text { data documentation centre of South } \\
\text { Asian Silk Roads Heritage Corridor(s), } \\
\text { eventually in the future category II } \\
\text { centre in New Delhi }\end{array}$ & $\begin{array}{l}\text { As early as } \\
\text { possible }\end{array}$ & to be defined \\
\hline
\end{tabular}




\begin{tabular}{|c|c|c|c|}
\hline $\begin{array}{l}\text { China, India and } \\
\text { Nepal } \\
\text { Bhutan }+\ldots\end{array}$ & $\begin{array}{l}\text { Checking and updating, if necessary, } \\
\text { amendment of existing legislations } \\
\text { Preparation or finalization and } \\
\text { dissemination of conservation norms } \\
\text { and holistic management plans of the } \\
\text { South Asian Silk Roads sites within the } \\
\text { context of each State Party }\end{array}$ & $\begin{array}{l}\text { As early as } \\
\text { possible, at latest } \\
\text { by December } \\
2017\end{array}$ & to be decided \\
\hline $\begin{array}{l}\text { China, India and } \\
\text { Nepal } \\
\text { Bhutan (?) }+\ldots .\end{array}$ & $\begin{array}{l}\text { Sharing of the preliminary full text of } \\
\text { the nomination dossier }\end{array}$ & June 2017 & to be decided \\
\hline $\begin{array}{l}\text { China, India and } \\
\text { Nepal } \\
\text { Bhutan (?) }+\ldots .\end{array}$ & $\begin{array}{l}4^{\text {th }} \text { meeting of the South Asian Silk } \\
\text { Roads Working Group (adoption of the } \\
\text { draft dossier) }\end{array}$ & July 2017 & to be decided \\
\hline $\begin{array}{l}\text { China, India and } \\
\text { Nepal } \\
\text { Bhutan (?) }+\ldots\end{array}$ & $\begin{array}{l}\text { Submission of the South Asian Silk } \\
\text { Roads draft nomination dossier to } \\
\text { World Heritage Centre for the } \\
\text { preliminary review }\end{array}$ & September 2017 & to be decided \\
\hline $\begin{array}{l}\text { China, India and } \\
\text { Nepal } \\
\text { Bhutan }(?)+\ldots .\end{array}$ & $\begin{array}{l}5^{\text {th }} \text { meeting of the South Asian Silk } \\
\text { Roads Working Group (adoption of the } \\
\text { Final dossier) } \\
\text { Second meeting of the Steering } \\
\text { Committee }\end{array}$ & $\begin{array}{l}\text { December } 2017- \\
\text { January } 2018\end{array}$ & to be decided \\
\hline $\begin{array}{l}\text { China, India and } \\
\text { Nepal } \\
\text { Bhutan (?) + .... }\end{array}$ & $\begin{array}{l}\text { Submission of the final dossiers to } \\
\text { World Heritage Centre }\end{array}$ & $\begin{array}{l}\text { Mid of January } \\
2018\end{array}$ & to be decided \\
\hline
\end{tabular}




\section{Appendix 4: 'Almaty Agreement'}

Adopted in the 4th meeting of the Coordinating Committee of the Serial World Heritage Nomination of the Silk Roads, 24-25 November 2015, Almaty, Kazakhstan

\section{ALMATY AGREEMENT}

25 November 2015

\section{Introduction:}

As a result of previous international and regional consultation meetings and the efforts of the three previous Coordinating Committee Meetings between 2006 and 2012, two Silk Roads World Heritage nomination files were prepared and submitted by $1^{\text {st }}$ February 2013. These nominations were examined at the $38^{\text {th }}$ session of the World Heritage Committee in June 2014 (Doha, Qatar). Subsequently, the Committee inscribed the "The Silk Roads: the Routes Network of Chang'an - Tian-shan Corridor", submitted by the States Parties of China, Kazakhstan and Kyrgyzstan.

The $4^{\text {th }}$ Coordinating Committee Meeting brought together national focal points and experts from twelve countries which included nine countries members of the Silk Roads Coordination Committee: Afghanistan, Iran, Kazakhstan, Korea, Kyrgyzstan, Nepal, Tajikistan, Turkmenistan, and Uzbekistan and three partner countries: Bhutan, Pakistan and Turkey. The meeting also invited representatives from IICC Xi'an (China), the Secretariat of Silk Roads Coordination Committee, as well as UNESCO representatives and international resource persons to ensure the discussions on further technical assistance and cooperation.

\section{Aim:}

The aim of the Almaty Meeting was to review and update the Terms of Reference of the Silk Roads Coordination Committee; the State of Conservation on the first inscribed Serial Transnational Nomination "Silk Roads: the Routes Network of Chang'an - Tianshan Corridor" (China, Kyrgyzstan and Kazakhstan); the Current status of the referred nomination "Silk Roads Penjikent-Samarkand-Poykent Corridor" (Tajikistan and Uzbekistan); to review the progress of the Silk Road World Heritage Nominations processes including the South Asian Silk Roads (Nepal, Bhutan, China and India), the FerganaSyrdarya Silk Roads Heritage Corridor (Kazakhstan, Kyrgyzstan, Tajikistan and Uzbekistan) as well as other Silk Roads initiatives from Afghanistan, Iran, Pakistan, Turkey and Turkmenistan. Furthermore, the Meeting also reviewed the results of the UNESCO/Japanese Funds-in-Trust (FIT) project "Support of documentation standards and procedures of the Silk Roads World Heritage Serial and Transnational Nomination in Central Asia”, 2011-2014, officially launched the UNESCO/Japanese FIT project "Support for the Silk Roads World Heritage Sites in Central Asia" (Phase II, 2015-2018) and reviewed the results of the ongoing UNESCO/Korean FIT South Asian Silk Roads project, 2013-2015. Finally, the Meeting also discussed potential needs regarding further development of the ICOMOS Silk Roads Thematic Study covering Eastern Asia and Western Asia.

\section{Main Outcomes:}

The participants of the meeting agreed on the following:

1. To update the Terms of Reference of the Silk Roads Coordination Committee; including welcoming Pakistan and Turkey as Coordination Committee members and Bhutan as an observer;

2. To note the good results of the UNESCO/Japanese FIT project "Support of documentation standards and procedures of the Silk Roads World Heritage Serial and Transnational Nomination in Central Asia”, 2011-2014;

3. To acknowledge the official launch of the UNESCO/Japanese FIT project "Support for the Silk Roads World Heritage Sites in Central Asia" (Phase II, 2015-2018);

4. To further strengthen the collaboration between China, Kyrgyzstan and Kazakhstan on the effective monitoring of the State of Conservation for the first inscribed Serial Transnational Nomination "Silk Roads: the Routes Network of Chang'an - Tianshan Corridor"; 
5. To reinforce the existing Expert Group of representatives from Central Asia and China, in collaboration with the IICC - Xi'an, Secretariat of the Coordinating Committee, through virtual communications;

6. To welcome further work on the referred nomination "Silk Roads Penjikent-SamarkandPoykent Corridor" by Tajikistan and Uzbekistan, and welcome Turkmenistan in preparation of the nomination dossier on the Silk Roads corridors located within the territory of Turkmenistan;

7. To note the good results of the UNESCO/Korea Funds-in-Trust South Asian Silk Roads project, 2013-2015;

8. To encourage close consultation and coordination between Nepal, Bhutan, China and India on the preparation of the South Asian Silk Road World Heritage Nominations, and express the desire to continue the UNESCO/Korea Funds-in-Trust South Asian Silk Roads project (Phase II), and encourage Pakistan and other related South Asian countries to join this nomination process;

9. To encourage the close consultation and coordination between Kazakhstan, Kyrgyzstan, Tajikistan and Uzbekistan about the preparation of the Fergana-Syrdarya Silk Roads Heritage Corridor World Heritage Nomination process;

10. To acknowledge the efforts of other Silk Roads initiatives from Afghanistan, Iran, Pakistan, Turkey and Turkmenistan;

11. To enhance the technical capacity of the respective governments, UNESCO National Commissions, and/or relevant authorities within each participating State Party for the preparation of the Silk Roads World Heritage nominations (both national and transnational);

12. To develop and implement an appropriate management system and tourism strategy for the identified Silk Roads nominations (both national and transnational);

13. To enhance the exchange of information related to the required documentation for preparation of nomination dossiers; and to further take note of UNESCO Silk Road Online Platform;

14. To call upon all participating State Parties to allocate the necessary funds and resources for the timely preparation of nomination dossiers;

15. To recognize the needs and the continuation for further development of the ICOMOS Silk Roads Thematic Study covering Eastern Asia and Western Asia with active support from the participating countries;

16. To extend the functions of two co-chairpersons until the next Coordinating Committee on the Serial World Heritage Nomination of the Silk Roads

Furthermore, the meeting also noted the potential target date for the official submission of the referred nomination "Silk Roads Penjikent-Samarkand-Poykent Corridor" transnational nomination dossier to be $\mathbf{1}$ February 2017, it is desirable for the participating countries to submit the required information to the World Heritage Centre as soon as possible.

The meeting welcomed the proposal of Iran to co-host with UNESCO the next meeting of the Coordinating Committee to take place in Iran before end 2016.

Delegates of the Fourth Meeting of the Coordinating Committee on the Serial World Heritage Nomination of the Silk Roads expressed their gratitude to the:

- Government of Kazakhstan, in particular the Ministry of Foreign Affairs, the National Commission for UNESCO and ISESCO, the Ministry of Culture and Sport, and other authorities in Kazakhstan, for hosting the meeting, for their warm hospitality, for their support, and for the provision of favourable conditions that allowed the successful organisation of the meeting;

- UNESCO World Heritage Centre, the UNESCO Offices in Almaty and Tashkent as well as to the international resource persons for facilitating the meeting;

Moreover, participants were extremely appreciative for the financial contributions for the meeting from the UNESCO World Heritage Centre Regular Programme, the UNESCO/Japan Funds-in-Trust Central Asian Silk Roads project and the UNESCO/Korea Funds-in-Trust South Asian Silk Roads project, as well as support from the Government of Kazakhstan. 

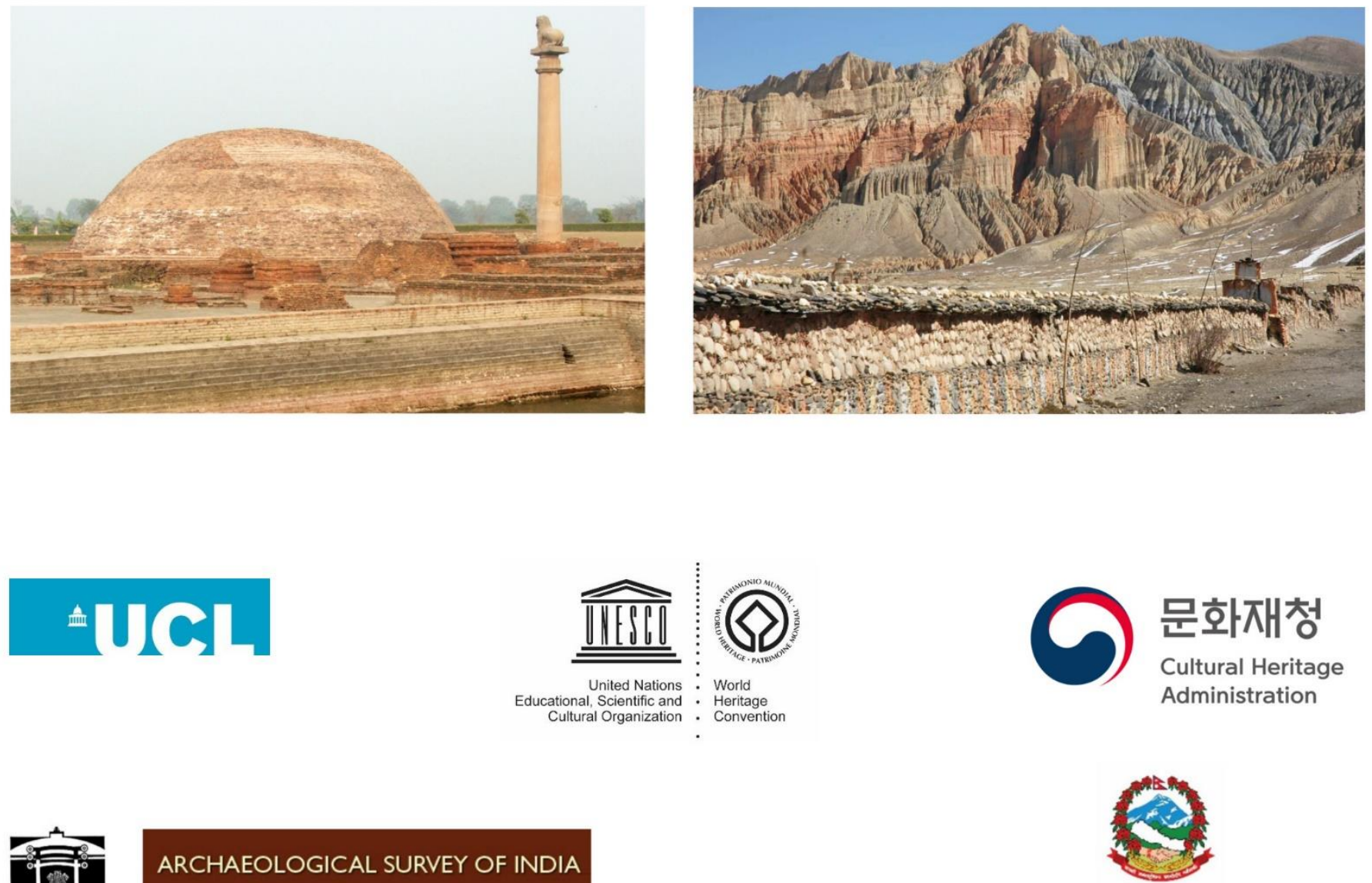

Government of Nepal Ministry of Culture, Tourism and Civil Aviation Department of Archaeology

\section{Institute of Archaeology \\ University College London}

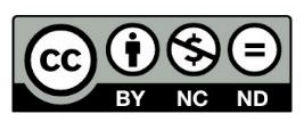

ISBN: 978-0-9956132-0-1

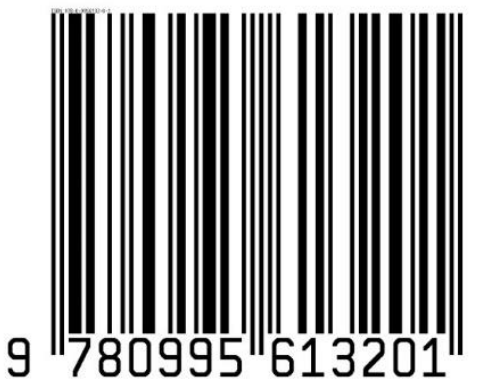

